12 Universidade de São Paulo - Escola de Comunicações e Artes

Programa de Pós-graduação em Ciências da Comunicação

Área de Concentração: Estudo dos Meios e da Produção Midiática

Linha de Pesquisa: Comunicação Impressa e Audiovisual

Dissertação de Mestrado

Aluna: Luiza Helena Gonçalves Caires

Orientadora: Profa. Dra. Nancy Nuyen Ali Ramadan

\title{
Quem faz a mídia no CMI Brasil: Jornalismo alternativo, ativista e colaborativo na internet
}

São Paulo, julho de 2010. 
Luiza Helena Gonçalves Caires

\section{Quem faz a mídia no CMI Brasil: Jornalismo alternativo, ativista e colaborativo na internet}

Dissertação de Mestrado apresentada ao Programa de Pós-graduação em Ciências da Comunicação, Área de Concentração: Estudo dos Meios e da Produção Midiática, Linha de Pesquisa: Comunicação Impressa e Audiovisual, da Escola de Comunicações e Artes da Universidade de São Paulo, como requisito parcial para obtenção do título de Mestre em Comunicação.

Orientadora: Profa. Dra. Nancy Nuyen Ali Ramadan

São Paulo, julho de 2010. 
Caires, Luiza Helena Gonçalves.

Quem faz a midia no CMI Brasil: Jornalismo alternativo, ativista e colaborativo na internet. 2010: $263 \mathrm{f}$.

Dissertação (Mestrado)

Universidade de São Paulo

Escola de Comunicações e Artes. São Paulo, 2010.

Orientadora: Profa. Dra. Nancy Nuyen Ali Ramadan

1. Centro de Mídia Independente 2. Jornalismo alternativo 3. Jornalismo cidadão 4. Ativismo 5. Perfil 
Comissão julgadora

São Paulo, ___ _ 2010. 
Dedico este trabalho aos ativistas de todas as épocas e locais. 


\section{Agradecimentos}

À minha orientadora, sempre disponível e parceira.

Aos meus pais, por todo o apoio e crédito em minha capacidade.

À Mira, pela amizade, e por me estimular ao trabalho acadêmico.

A todos os voluntários do CMI, que acreditaram na seriedade e valor do trabalho, $e$ que colaboraram enormemente na produção desta dissertação. Especialmente: Marcelo, Toya, Foz, Drebs, Miryám, Flecha, Eric, Elisa, Kit, Isadora, Pablo, Felipe, Rato;

Ao CNPq, pelo financiamento da etapa inicial desta pesquisa. 


\section{Resumo}

A dissertação teve como objetivo delinear o perfil de dois grupos: aqueles que mantêm a estrutura, como voluntários, do CMI - site da Rede Indymedia representante nacional do jornalismo cidadão ou open source - e também os que postam conteúdo nele, sem necessariamente ser voluntário. Como método, foram realizadas duas pesquisas empíricas, uma levantando dados mais objetivos do segundo grupo, e outra, baseada em entrevistas abertas, com o primeiro. Dos usuários foram obtidos dados como profissão, gênero, idade, orientação política, hábitos de navegação e postagem; e dos voluntários, valores, crenças, histórias de vida e atividades dentro do grupo. Também foram pesquisados os assuntos e formatos de texto mais recorrentes postados na seção aberta do site.

O material obtido e o recurso a um referencial teórico apropriado propiciou como resultado uma análise do veículo e seus participantes à luz das teorias que tematizam: o papel das novas tecnologias na comunicação, e numa possível democratização de seu espectro; os conceitos de jornalismo; jornalismo cidadão, colaborativo ou open source; e jornalismo alternativo; as abordagens sociológicas do ativismo e dos movimentos sociais contemporâneos de uma perspectiva estratégica e cultural; e das relações dos movimentos sociais com a comunicação - principalmente em relação às mídias que eles mesmos produzem, e que, fundamentalmente, por não se enquadrarem nos parâmetros do mercado, e focalizarem a luta por mudanças, podemos chamar de 'alternativa'.

\section{Palavras-chave}

Centro de Mídia Independente | Jornalismo alternativo | Jornalismo cidadão | Ativismo | Perfil 


\section{Abstract}

This work aims to outline the profile of two groups: those who maintain the structure, as volunteers, of CMI - site of Indymedia Net, nationally representative of citizen and open source journalism - and also those who post content on it, without necessarily being a volunteer. As a method, we carried out two empirical studies, raising a more objective data from the second group, and another based on open interviews with the former. Users' data were obtained as: profession, gender, age, political orientation, browsing and postage habits; and from volunteers: values, beliefs, life stories and activities within the group. We have also researched the subjects and text formats more applicants posted in the open section of the site.

The obtained material and the use of an appropriate theoretical reference provided as a result an analysis of the vehicle and its participants, using the theories that work with: the role of new technologies in communication, and a possible democratization of its spectrum; the concepts of: journalism; citizen, collaborative or open source journalism; alternative journalism; sociological approaches of the activism and the contemporary social movements - from a strategic and cultural perspective; and relationships between social movements and communication, especially referring to the media that they themselves produce, that not fit the parameters of the market and that focus the fight for change - and that's why we call it 'alternative'.

\section{Keywords}

Centro de Mídia Independente | Alternative journalism | Citizen journalism | Activism| Profile 


\section{Sumário}

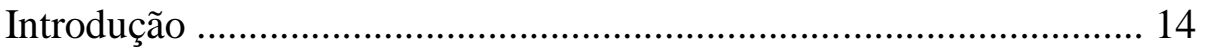

Capítulo 1 - O Centro de Mídia Independente Brasil o que é, como surgiu e como funciona ................................................ 20

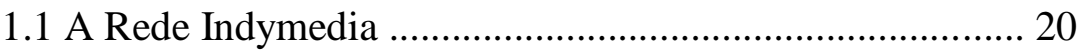

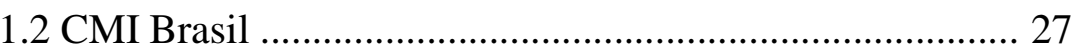

1.3 Como funciona o site do CMI ......................................... 36

Capítulo 2 - Quem faz a mídia no

$\mathrm{CMI}$ - a coluna da direita

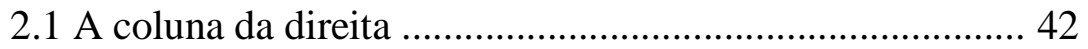

2.1.1 Metodologia - pesquisa com usuários da coluna da direita

2.1.2 Resultados - pesquisa com usuários da coluna da direita 76

2.2 Considerações a partir dos resultados - pesquisa com usuários da coluna da direita

Capítulo 3 - Quem faz a mídia no

CMI - voluntários e organizadores.

3.1 Metodologia - pesquisa com voluntários

e organizadores do CMI

3.2 Entrevistas

Capítulo 4 - Caracterizando os voluntários

do CMI - discurso e práticas

4.1 O discurso do grupo que constitui

o CMI - frame analysis. 
4. 1.1 Frames: da estratégia à cultura, da cultura à estratégia

4.1.2 Collective Action Frames

4.1.3 Frame alignment 208

4.1.4 Características variáveis dos collective action frames

4.2 Práticas: ativistas, jornalistas 229

4.2.1 Ativismo 229

4.2.2 Jornalistas 231

Conclusão (considerações finais) 249

Referências bibliográficas e webgráficas 256 


\section{Lista de figuras e tabelas}

Fig. 1.1 Hierarquia de conteúdos publicados.

Fig. 2.1 Gráfico comparativo de postagens por seção

Fig. 2.2 Assunto: Problemas sociais

Fig. 2.3 Assunto: Problemas sociais

Fig. 2.4 Assunto: Problemas ambientais

Fig. 2.5 Assunto: Problemas ambientais

Fig. 2.6 Assunto: Movimento pela libertação animal

Fig. 2.7 Assunto: Movimento pela libertação animal

Fig. 2.8 Assunto: Direitos de minorias étnicas

Fig. 2.9 Assunto: Direitos de minorias étnicas

Fig. 2.10 Assunto: Direitos de minorias sexuais

Fig. 2.11 Assunto: Direitos de minorias sexuais

Fig. 2.12 Assunto: Política (geral)

Fig. 2.13 Assunto: Política (geral)

Fig. 2.14 Assunto: Política (geral)

Fig. 2.15 Assunto: Política nacional 
Fig. 2.16 Assunto: Política nacional

Fig. 2.17 Assunto: Política - internacional (América Latina)

Fig. 2.18 Assunto: Política - internacional (Estados Unidos)

Fig. 2.19 Assunto: Política - internacional (Oriente Médio)

Fig. 2.20 Assunto: Política - internacional (Europa)

Fig. 2.21 Assunto: Mídia

Fig. 2.22 Assunto: Mídia

Fig. 2.23 Assunto: Movimento estudantil

Fig. 2.24 Assunto: Movimento estudantil

Fig. 2.25 Assunto: Movimento sindical

Fig. 2.26 Assunto: Movimento sindical

Fig. 2.27 Assunto: Conteúdo sem relação com a política editorial

Fig. 2.28 Assunto: Conteúdo sem relação com a política editorial

Fig. 2.29 Gráfico de postagens por assunto

Fig. 2.30 Gráfico de postagens por formato

Fig. 2.31 Gráfico de usuários por sexo

Fig. 2.32 Gráfico de usuários por idade 
Fig. 2.33 Gráfico de usuários por região

Fig. 2.34 Gráfico de usuários por nível educacional

Fig. 2.35 Gráfico de usuários por tempo há que acessa o site do CMI

Fig. 2.36 Gráfico de usuários por orientação política

Fig. 2.37 Gráfico de usuários por participação ou não em organização ou movimento social

Fig. 2.38 Gráfico de usuários por participação ou não em outro site ou blog

Fig. 2.39 Gráfico de usuários por participação ou não em reunião ou lista de emails de coletivo do CMI

Fig. 4.1 Características variáveis dos collective action frames

\section{Anexos}

Anexo 1 - Página principal do site da Rede Indymedia - http://www.indymedia.org Acesso em 19/07/2010.

Anexo 2 - CMI na Rua número 26, fevereiro de 2006

Anexo 3 - CMI na Rua úmero 28, novembro de 2006

Anexo 4 - Ação Direta, setembro de 2002 


\section{Introdução}

Ainda existe jornalismo alternativo no Brasil? Quais os critérios para responder a esta pergunta? Se a resposta for afirmativa, como ele se caracteriza? E, principalmente, estes jornalistas alternativos têm uma "cara"?

Tais questionamentos, por certo amplos, são parte das inquietações que moveram o empreendimento deste trabalho. A escolha específica do Centro de Mídia Independente Brasil (CMI) como veículo estudado não foi, portanto, aleatória. Tratase, em nosso entender - reforçado após a pesquisa - do mais importante veículo de mídia alternativa em ação no País. Alternativa na temática, alternativa na forma como é feita, e alternativa porque seu projeto é baseado numa crença mais geral de que um “alter" mundo, mais justo, é necessário. E que somente com a ferramenta da ação que inclui a comunicação - é possível construí-lo.

Algumas palavras introdutórias, então, sobre sua história, motos, esta forma de fazer, e sobre a nossa proposta.

Percebemos que quase uma década e meia após a difusão do uso da internet, os portais de grupos tradicionais de mídia do Brasil continuam trabalhando com o modelo unidirecional de comunicação, definindo centralizadamente o quê e como será publicado, baseando-se em determinados critérios jornalísticos que desembocam na produção de notícias julgadas relevantes para seu público.

Muito recentemente, começamos a ver a prometida interatividade em

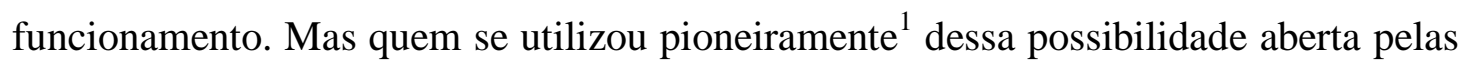

\footnotetext{
${ }^{1}$ Recentemente os sites dos grandes grupos criaram seções para envio de notícias, fotos e vídeos pelos próprios leitores. Como exemplos temos as seções: Vc repórter, do portal Terra (www.terra.com.br/vcreporter. Acesso em 13/03/2008) e Minha notícia, do iG (http://minhanoticia.ig.com.br. Acesso em 13/03/2008).

Exemplo de sites de jornalismo participativo brasileiros não ligados à grande mídia são o Wikinotícias (http://en.wikinews.org/wiki/Main_Page. Acesso em 13/03/2008) e o Overmundo (www.overmundo.com. Acesso em 13/03/2008). Porém, no Wikinotícias não encontramos tanto produção de notícias, mas sim adaptações, edições e indicações de notícias de outros veículos, numa prática de "passar para frente" notícias que os usuários encontram e julgam interessantes o suficiente para serem destacadas. E o Overmundo é uma iniciativa colaborativa destinada a divulgar a arte e a cultura que não encontra espaço na grande mídia, ou seja, também não se trata de um noticiário genérico, mas setorizado no jornalismo cultural - e mantém um vínculo com instituições
} 
novas tecnologias foram veículos de conteúdo jornalístico que não pertencem a grandes grupos de mídia. No jornalismo cidadão ou open source (referência às comunidades inaugurais no uso da Rede para trabalho colaborativo, que foram os programadores dos softwares livres, de código aberto) a interatividade chega a subverter a ordem tradicional de uma comunicação unidirecional emissor-receptor, oferecendo a todos os usuários que participam os papéis de leitor/audiência, jornalista, e editor. Esse é o caso do Centro de Mídia Independente.

Braço brasileiro de uma rede mundial de ativistas surgido em 2001, o CMI é o exemplo mais antigo e duradouro, em âmbito nacional, de como as comunidades questionadoras do status quo têm utilizado as potencialidades ${ }^{2}$ da rede para difundir informação, contra-informação, e organizar grupos de ação. O site deixa explícita a sua linha editorial, que pretende utilizar a prática jornalista em favor da construção de "uma sociedade livre, igualitária e que respeite o meio ambiente". O inovador, em relação à mídia alternativa que conhecíamos até seu surgimento, foi a permissão de que qualquer pessoa adepta desta linha editorial - jornalista ou não - publique seu relato jornalístico. Característica resumida no mote: "Não odeie a mídia. Torne-se a mídia".

Criado em Seattle (EUA) em 1999, quando do "Encontro do Milênio" da OMC Organização Mundial do Comércio (OMC), o Independent Media Center (IMC) pioneiro, que deu origem aos demais coletivos em todo o mundo, foi desenvolvido por um grupo de jornalistas e ativistas políticos com o objetivo de fazer uma cobertura democrática e não-corporativa dos protestos que marcaram o evento. Ainda hoje o IMC é o meio de comunicação de referência para os movimentos antiglobalização, e possui sites permanentes e de conteúdo regional em diversos países.

A evolução da tecnologia nas comunicações e telecomunicações tem sido capitalizada pela grande mídia para tornar ainda mais eficientes suas estratégias de penetração em um público amplo, trazendo como consequência uma homogeneização

governamentais, já que é patrocinado pela Petrobrás. E temos o CMI, que além de pioneiro, segue um modelo alternativo e de proposta ativista.

${ }^{2}$ Uma das potencialidades mais comentadas atualmente, na onda da chamada "Web 2.0" - termo criado por Tim O'Reilly em "What Is Web 2.0” (O’Reilly, 2005) é a possibilidade de os usuários atuarem como difusores de conteúdo de toda espécie, trabalhando muitas vezes em ambientes colaborativos dinâmicos, em que usuários distribuídos em diferentes lugares do espaço geográfico atuam em conjunto para produzir resultados otimizados, seja na produção de um software de código aberto, seja para a construção de enciclopédias de autoria coletiva, para troca de vídeos e áudios, ou mesmo para produzir especificamente jornalismo, tendência em pleno crescimento e que estudamos nesta pesquisa. 
- senão da opinião - da pauta pública, ainda que o público aparentemente seja segmentado de acordo com suas preferências e critérios socioeconômicos. A concentração do poder de veicular nas mãos de grandes grupos multinacionais (principalmente quando falamos de meios menos recentes, como rádio, jornal, e televisão) tende a se exacerbar, e não recuar, a cada dia.

Agravando esse quadro, os custos elevados de impressão, a não democrática concessão das emissoras de rádio e TV, a falta de financiamento e a distribuição desigual das verbas publicitárias estatais têm condenado ao desaparecimento, ano a ano, os representantes da imprensa de conteúdo alternativo desenvolvida num formato mais tradicional. Veículos alternativos deste nicho no meio online também não estão imunes a tais condições adversas só porque não precisam de papel e distribuidores. Veja-se o caso da Agência Carta Maior, sob constante ameaça de fechamento por falta de recursos ${ }^{3}$.

Com sua dinâmica descentralizada de produção, o CMI usa a tecnologia e as particularidades dos novos meios na busca de seus objetivos, apontando caminhos para que as vozes dissonantes da sociedade não sejam caladas pelo rolo compressor dos gigantes da comunicação ${ }^{4}$.

(...) a centralidade das tecnologias de comunicação no processo de produção permite o surgimento de novas formas de cooperação e sociabilidade, contrárias à apropriação capitalista do trabalho. Neste contexto, a disseminação da Internet favorece a mudança de paradigma da produção de informações, de um modelo de mídia de massa, estabelecida para se adequar aos cânones da linha de montagem industrial (uniformidade, impessoalidade e imparcialidade), para a possibilidade de uma "mídia de multidão". A comunicação mistura-se com ativismo político, em redes de produção de notícias organizadas horizontalmente, em coletividades não-hierarquizadas, à parte do capital. (Burger, 2006, grifos nossos)

Mesmo com os prós e contras deste modelo inovador que ora investigamos, já podemos de saída perceber que ele desafia a descrença na sobrevivência da mídia

\footnotetext{
${ }^{3}$ A crise financeira inclusive foi exposta aos leitores no editorial do site de 26/03/2007. (Disponível em: http://agenciacartamaior.uol.com.br/templates/materiaMostrar.cfm?materia_id=13792. Acesso em 02/06/2007).

${ }^{4}$ Em "Mídia Global, neoliberalismo e imperialismo", Robert W. McChesney detalha como o processo de fusões da última década tem transformado o regime econômico sob o qual vivem empresas de mídia mais em um oligopólio do que num regime simples de concorrência, e destaca que o jornalismo é um dos primeiros pilares da democracia a sofrer com o fim da pluralidade. (McChesney, 2003)
} 
alternativa e na possibilidade de uma comunicação democrática diante do atual quadro de fusões e monopólios - onde grandes engolem os menores. Ainda, faz um uso diferenciado do meio internet na produção jornalística, tornando a Web uma rede $e^{5}$ de fato - e com uma postura declaradamente ativista $^{6}$.

Jornalistas podem escrever para o CMI e, de fato, há certo número destes profissionais que trabalha voluntariamente para a manutenção e atualização do site (e dos sites, já que há diversos coletivos regionais) do Centro. Entretanto, ele é voltado principalmente para que quem não é jornalista também possa publicar e, em nosso entender, em tal permissão poderia residir um dos trunfos para seu sucesso. Um veículo que se coloca como alternativo e democrático deve noticiar os fatos da perspectiva de visões e opiniões múltiplas (ainda que sejam as diferentes visões e opiniões de quem trabalha por um objetivo comum, explícito na política editorial do site).

A liberdade de postagem permite uma prática descentralizada, que favorece a chegada de notícias e artigos de todo o País, dando ao portal uma atualização constante. Embora essa atualização não venha necessariamente acompanhada de qualidade da informação, em particular no caso da coluna da direita - problemática discutida neste trabalho.

Quando falamos de redes no meio online, voltamo-nos imediatamente ao conceito de comunidades virtuais. Ampliando um pouco a definição de Howard Rheingold, dizemos que comunidades virtuais são grupos sociais que se reúnem através da CMC (Comunicação Mediada por Computador), promovem trocas de

\footnotetext{
${ }^{5}$ A análise das redes é o eixo dos estudos do sociólogo Manuel Castells. Para ele, as redes são "a nova morfologia social de nossas sociedades, e a difusão da lógica de redes modifica de forma substancial a operação e os resultados dos processos produtivos e de experiência, poder e cultura." (Castells, 1999). No entanto, na obra citada, Castells ainda focaliza o funcionamento em rede de todos os dispositivos que mantêm o capitalismo global atual (mercados de ações, mídia massiva, livre fluxo do capital, entre outros). E em uma obra posterior, "Galáxia da Internet", chega a afirmar que as conexões originais das comunidades virtuais com a contracultura se enfraqueceram. (Castells, 2003).

Mas, na nossa pesquisa, pretendemos estudar o CMI justamente como um exemplo de uso da rede antagônico àqueles dispositivos do capitalismo global e a essa tendência de enfraquecimento do caráter contracultural das redes apontada por Castells.

${ }^{6}$ Um exemplo recente de matéria publicada no CMI sobre o Movimento pelo Passe Livre (MPL) retrata bem o seu caráter de mídia marginal, que cobre temáticas que as grandes redes ignoram: "Na contramão da mídia corporativa, que dá destaque ao chamado "caos aéreo", o MPL volta sua atenção para as 35 milhões de pessoas que, de acordo com dados do Ministério das Cidades, não utilizam transporte coletivo por não terem dinheiro para pagar as tarifas; lembra também das filas nos pontos de ônibus e dos ônibus superlotados.” (http:// www.midiaindependente.org. Acesso em 28/10/07).
} 
experiências, discussões públicas e tocam projetos coletivos, formando redes de relacionamento pessoal, profissional e político no ciberespaço, em territórios que não se definem por fronteiras físicas, mas por afinidade de interesses. (Rheingold, 1998)

No nosso entender, o CMI constitui um veículo jornalístico online tocado por uma comunidade predominantemente virtual, voltada principalmente à geração, troca e gestão coletiva de informações com objetivos políticos. A comunidade virtual que torna o Centro possível apresenta uma configuração em rede bem específica lembrando que há diversas maneiras de uma produção coletiva se organizar ${ }^{7}$, incluindo procedimentos de filtragem de conteúdo, moderação, eleição e qualificação dos participantes por sistemas de valoração variados, e outros - escolhida não ao acaso para servir à sua estrutura de produção e difusão de informações e notícias.

O IMC institui um processo e apuração das informações e de tomadas de decisões editoriais que se dá através das listas de discussão mundiais, regionais ou locais. Nelas, os ativistas sugerem, emitem opiniões sobre questões, problemas técnicos e editoriais que vão surgindo. Em um processo contínuo e dialógico, chegam a consensos tanto sobre tecnologias, configurações de softwares, temáticas a serem exploradas e direcionamentos tomados no trabalho interno quanto à postura editorial. $\mathrm{O}$ coletivo técnico trabalha com a manutenção da infra-estrutura que mantém o sistema e os servidores. O editorial produz as informações que estão dispostas na área central do sítio, aquelas pelas quais o IMC é responsável. (Schwingel, 2004)

\section{A proposta}

Já existe algum conhecimento acumulado sobre estes assuntos, em particular do ponto de vista da compreensão da natureza teórica do fenômeno jornalismo cidadão no contexto da internet e novas tecnologias, como notamos no levantamento

\footnotetext{
${ }^{7}$ Temos vários exemplos de comunidades virtuais de produção de conteúdo com uma organização diversa à do CMI. Um deles é o Slashdot (http://slashdot.org. Acesso em 13/03/2008), portal colaborativo para divulgação de informações e notícias relacionadas à tecnologia em que há um complexo processo de newsmaking. A edição é feita a partir de 300 a 400 stories submetidas por dia pelos leitores. Um grupo de oito pessoas é responsável pela seleção do material. A segunda forma de participação dos leitores-redatores se dá através de comentários, moderados por indivíduos selecionados por uma espécie de ranking do site, que avalia a assiduidade de participação dos usuários e distribui "pontos de influência". Com esses pontos, os moderadores podem classificar as mensagens deixadas pelos leitores em uma escala que vai de -1 a 5 , num valor crescente de qualidade da informação. (Breier, sem data). Tal sistema garante o bom nível e a veracidade da notícias publicadas no Slashdot, contrariando a crença de que o jornalismo open source não pode ser pautado pela qualidade, apenas por não apresentar um controle centralizado. Também é interessante ressaltar que há um processo em curso de atualização do método de publicação de notícias na coluna da direita do CMI, que deve contar com um sistema de valoração com alguma semelhança ao do Slashdot.
} 
inicial da produção sobre o tema. Mais ainda, esta base de conhecimentos tem se desenvolvido na direção de aproximação do objeto com recortes mais circunstanciados da realidade, inclinando-se ao ajuste de foco, ao detalhamento de fenômenos culturais específicos, enfim, dados do problema que devem ser efetivados pela pesquisa de aspectos empíricos. Deste modo, encaminha-se pelo fornecimento de novos dados e informações o processo de conhecimento atualmente em curso.

Tendo em vista esta perspectiva, a nossa abordagem sobre o jornalismo praticado no CMI toma como objetivo principal a tarefa de traçar o perfil de dois grupos: os voluntários que mantêm a estrutura do veículo; e os usuários-provedores, aqueles que acessam e postam conteúdo no site deste veículo, que é um dos maiores representantes nacionais do jornalismo cidadão ou open source quando se pensa em mídia alternativa - ambos os conceitos discutidos na dissertação.

Além de um levantamento por amostragem ${ }^{8}$ das características dos usuários da coluna da direita do site (onde a postagem é livre e aberta) - aferindo dados como profissão, sexo, idade, orientação política, hábitos de navegação e outros -, entrevistamos voluntários, moderadores e participantes do coletivo editorial (que também postam conteúdo na coluna central, esta editada) e/ou que participam das reuniões e listas de email do coletivo de São Paulo: um dos mais ativos no Brasil, e onde o CMI começou.

Destes últimos construímos retratos, por meio de entrevistas e análise de sua atuação, buscando traçar um quadro qualitativo de tais produtores de mídia, na tentativa de entender as características, as potencialidades e os limites da dinâmica escolhida pelo CMI para a prática desta modalidade de jornalismo (colaborativo, cidadão, de open source), especificamente no caso da mídia alternativa articulada com o ativismo dos movimentos sociais, isto é, voltada à promoção de transformações.

Os resultados deste esforço de pesquisa poderão contribuir para o entendimento mais concreto da dinâmica e dos processos deste modelo de jornalismo e também fornecer elementos para um diagnóstico menos genérico da realidade local.

\footnotetext{
${ }^{8}$ A pesquisa por amostragem é um método de conceber um número finito de indivíduos ou casos de uma população ou universo, para produzir um grupo representativo, utilizado em situações em que é difícil obter informações de todos os membros da população pesquisada: "É um método indutivo de conhecimento de todo o universo estatístico, através de um número representativo de amostras aleatórias desse universo" (Ferrari, 1982).
} 


\section{Capítulo 1}

\section{O Centro de Mídia Independente Brasil - o que é, como surgiu e como funciona}

\subsection{A Rede Indymedia}

De 30 de novembro a 3 de dezembro de 1999, a cidade de Seattle, nos Estados Unidos, recebeu a terceira World Trade Organization Ministerial Conference, apelidada de "N30". Pretendendo ser o lançamento de uma nova rodada de negociações da Organização Mundial do Comércio (OMC), este "Encontro do Milênio" foi o mote para a ida às ruas de numerosos protestos do movimento antiglobalização. Nas proximidades da sede da conferência, viam-se grupos ativistas nacionais e internacionais de diferentes propósitos, mas unidos naquele momento contra as políticas de livre comércio da OMC.

Preocupada com uma possível cobertura insuficiente ou inadequada dos protestos pelos grandes órgãos de imprensa tradicionais, um grupo de organizações e ativistas de mídia alternativa começaram a planejar algo inovador na época: uma ferramenta que possibilitasse uma cobertura grassroots $^{9}$ dos eventos. Após o registro do domínio www.indymedia.org, e com um fundo coletivo de doações, os voluntários criaram o primeiro Independent Media Center (IMC). Por meio de um sistema de publicação aberta, em que os leitores eram ao mesmo tempo os produtores de conteúdo, o site foi alimentado com textos, fotografias, vídeos e arquivos de áudio captados diretamente nas ruas do centro de Seattle, gerando mais de dois milhões de visitas durante os dias dos protestos.

Presented by regular people through a first-class democratic medium, showing the rubber bullets corporate media did not see, airing voices corporate media did not hear, the content of Indymedia provided almost instantaneous

\footnotetext{
${ }^{9}$ Grassroots - etimologicamente, no inglês: raízes de grama, geralmente traduzido como "de base". Neste caso, sublinha a característica espontânea e pulverizada do movimento, em que parte da própria comunidade o desejo de contestação, que se transforma em ação espontaneamente articulada, sem a necessidade de um comando central. Optamos por não traduzir como "popular" ou "de base" quando referente a cobertura ou jornalismo, mantendo o termo em inglês.
} 
news reporting to a global audience. Complementing the regular seven o'clock news in a significant, yet specific way, Indymedia's input was vital to portraying a more complete picture of the actual events which took place during the N30 protests.

Apresentado por pessoas comuns através de um meio democrático de primeira classe, mostrando as balas de borracha que mídia corporativa não via, dando espaço às vozes que mídia corporativa não ouvia, o conteúdo do Indymedia fornecia notícias de forma quase instantânea para uma audiência global. Complementando as tradicionais de notícias das sete horas de um modo significativo, contudo específico, a entrada do Indymedia foi vital para traçar um quadro mais completo dos eventos reais que ocorreram durante os protestos do N30. (Uzunova, 2007, p.2, tradução nossa)

Assim foi que a chamada "Batalha de Seattle" foi amplamente e documentada e transmitida em tempo real, de maneira inédita para um protesto até então, não só complementando a cobertura do noticiário tradicional, que priorizava fontes oficiais (polícia, organização da conferência, prefeitura), mas de um ponto de vista totalmente diferente, por ser feito por milhares de ativistas que estavam diretamente envolvidos e nos locais dos acontecimentos.

No começo do ano 2000 teve início o surgimento de diversos IMC em outros locais, adotando o mesmo modelo e proposta do original. Em fevereiro de 2000 foi formado o coletivo de Boston, inicialmente para cobrir as manifestações contra a Biotechnology Industry Organization Convergence (BIO Convergence), seguido pelo IMC de Washingnton, para cobrir os protestos de 16 de abril (A16) contra o Banco Mundial e o Fundo Monetário Internacional (FMI). Até o final de 2000, 30 IMC estavam estabelecidos ao redor do mundo, número que dobraria no início de 2001, passando a 170 em 2007. Como descreveu Uzunova, progressivamente, o "Indymedia construiu uma rede, uma cena social emergente trazendo o potencial de alcançar uma maior democracia através dos meios tecnológicos" ${ }^{\prime 10}$. (Idem, p.3, tradução nossa)

As declarações de apoio, obtidas junto a especialistas em mídia e entusiastas à proposta da rede Indymedia, compiladas abaixo, mostram a repercussão da atuação do grupo $^{11}$.

\footnotetext{
10 "Indymedia built a network, an emerging social scene carrying the potential to achieve greater democracy through means of technology." (Uzunova, 2007, p.3)
} 
Everywhere I go in the world, from Melbourne to Rome, London to Rio, the IMC is there: young, terrifyingly competent activist-journalists, wielding mini-disk recorders and hand-held digital cameras. Embodying the best ethos of direct-action, they are telling the stories of the new activism for themselves instead of waiting for them to be told by "professionals," reclaiming the media instead of simply complaining about its inadequacies.

The IMC Network is more than a vital news outlet filling gaping holes in mainstream coverage, it is also a new paradigm for participatory activism. No political project that I know of has come as close to being both deeply local and genuinely global at once. It has spun a decentralized web of centres that are internationally linked, through which tens of thousands of people scattered around the world are able to feel that their local work is part of a common global project.

Onde quer que eu vá no mundo, de Melbourne a Roma, de Londres ao Rio, o IMC está lá: ativistas-jornalistas jovens e assustadoramente competentes empunhando mini-gravadores e câmeras digitais portáteis. Encarnando o melhor ethos da ação direta, eles estão contando as histórias do novo ativismo por eles mesmos, em vez de esperarem que sejam contadas por "profissionais", recuperando a mídia em vez de simplesmente reclamar sobre os problemas dela.

A Rede IMC é mais do que uma produção de notícias vital para preencher os buracos da cobertura mainstream, é também um novo paradigma para o ativismo participativo. Nenhum projeto político que eu conheço chegou tão perto de ser ao mesmo tempo profundamente local e verdadeiramente global. Ele teceu uma teia descentralizada de grupos que são internacionalmente vinculados, através da qual dezenas de milhares de pessoas espalhadas ao redor do mundo são capazes de sentir que o seu trabalho local é parte de um projeto comum global. (Naomi Klein, escritora e ativista, tradução nossa)

$* * *$

The emergence of Independent Media Centers over the past two years has been one of the most extraordinary developments in independent media in a generation. Taking advantage of revolutionary new digital technologies and the internet, Indymedia has developed a network of grassroots' "people's" journalists.

O surgimento do Centro de Mídia Independente nos últimos dois anos foi um dos acontecimentos mais extraordinários da mídia independente nesta

${ }^{11}$ Extraído de material enviado por participante da rede Indymedia. Encontramos referência apenas na internet para estas citações, que constam na documentação do site ou em poder de alguns participantes mais antigos: http://archives.lists.indymedia.org/imc-editorial/2000-October/000656.html Acesso em 25/09/2009. 
geração. Aproveitando-se da nova e revolucionária tecnologia digital e da internet, o Indymedia desenvolveu uma rede grassroots de jornalistas "do povo". (Robert W. McChesney, professor do Institute of Communications Research University of Illinois, tradução nossa)

Not enough accolades can be given to the Independent Media Center. It is doing what is both courageous and obvious, stepping into the vacuum left by the corporatization of the networks and PBS and providing truthful accounts of how unheard Americans think and feels. I cannot emphasize how important the Independent Media Center is and has become. We cannot win the battle for Global democracy without it.

Nenhum elogio que possa ser feito ao Centro de Mídia Independente é suficiente. Ele está fazendo o que é ao mesmo tempo corajoso e óbvio: a entrada no vácuo deixado pela corporativização das redes e da PBS [canal público] e o fornecimento de relatos verdadeiros sobre como os americanos que não são ouvidos se sentem e pensam. Eu não consigo enfatizar o bastante o quão importante o Centro de Mídia Independente é, e se tornou. Nós não podemos vencer a batalha pela democracia global sem ele. (Paul Hawken, ambientalista e escritor, tradução nossa)

The IMC is a nascent, experimental phenomenon. It is impossible to calculate how many people are involved, as participation in the volunteer-run group runs the gamut from those who work full-time to keep the infrastructure running, to those who post a single story during a specific event. The IMC has no world headquarters, but if it can be said to be located anywhere, that location is at the convergence of several critical trends: the rebirth of activism, the maturation of the internet, and the crystallization of what they see as a new evil in the form of out-of-control corporatism.

Using the Net for activism is nothing new. What makes Indymedia radical is a steadfast commitment to decentralisation and a desire to fuse the guiding principles of the free software movement with the ideals of participatory democracy.

O IMC é um fenômeno nascente e experimental. É impossível calcular quantas pessoas estão envolvidas nele, já que a participação no grupo de voluntários vai de uma gama de pessoas que trabalham em tempo integral para manter a infraestrutura em execução, até quem posta uma história única, durante um evento específico. O IMC não tem sede mundial, mas se pode se dizer que está localizado em qualquer lugar - a localização está na convergência de 
diversas tendências críticas: o renascimento do ativismo, a maturação da internet, e a cristalização do que eles vêem como um novo mal na forma do corporativismo sem controle.

Usar a rede para o ativismo não é novo. O que torna o Indymedia radical é um firme compromisso com a descentralização e um desejo de fundir os princípios orientadores do movimento de software livre com os ideais da democracia participativa. (Hillary Rosner, jornalista, tradução nossa)

$* * *$

People all over the world are raising their voices and expressing their outrage against the greed of the multinational corporations and the unwillingness, and inability, of our governments to stop these institutions. To ensure that this happens, an Independent Media Center has been opened in Seattle. Such an effort is critical to the success of a people's movement for social change and I am fully supportive of the Independent Media Center. I would also strongly urge anyone interested in funding this project, to do so.

The need for independent media cannot be understated at a time when we experience the effects of corporate power in every level of our life and see the commercialization and consolidation of the means of communication becoming more entrenched. Our very democracy is at stake and independent media can be a powerful leveraging point.

Pessoas de todo o mundo estão levantando suas vozes e expressando sua indignação contra a ganância das multinacionais e a falta de vontade e incapacidade de nossos governos para brecar essas instituições. Para garantir que isso aconteça, o Centro de Mídia Independente foi inaugurado em Seattle. Tal esforço é fundamental para o sucesso de um movimento pela mudança social, e eu sou totalmente solidário com o Centro de Mídia Independente. Também recomendo fortemente que qualquer pessoa interessada em financiar este projeto o faça.

A necessidade de meios de comunicação independentes não pode ser subestimada num momento em que experimentamos os efeitos do poder corporativo em todos os níveis da nossa vida, e vemos a comercialização e a consolidação dos meios de comunicação cada vez mais enraizada. A nossa democracia está em jogo, e a mídia independente pode ser um ponto de alavancagem poderoso. (David Barsamian, radialista, fundador da Alternative Radio, tradução nossa) 
We need the Independent Media Center. In fact, there would be no way to justify its non-existence during the WTO ministerial in Seattle... Let the voices of the environment, of human rights, of labor, of consumers, of grassroots democracy, be heard. Let's support the Independent Media Center to help those voices be heard in Seattle and around the world.

Precisamos do Centro de Mídia Independente. Na verdade, não haveria maneira de justificar a sua não-existência durante a conferência da OMC em Seattle... Deixe as vozes do meio ambiente, dos direitos humanos, do trabalho, dos consumidores, da democracia de base, serem ouvidas. Vamos apoiar o Centro de Mídia Independente para ajudar que essas vozes sejam ouvidas em Seattle e ao redor do mundo. (Norman Solomon, crítico de mídia e diretor do Institute for Public Accuracy, tradução nossa)

Initially developed out of a synergy of public, civil and private cooperation, the internet has enabled this reformulation of political dynamics. However it is quickly becoming more and more privately driven. IndyMedia, an initiative of shared technologies, ideas and knowledge, has carried on the tradition from which the internet emerged. As Rhonda and Michael Hauben note in their history of Usenet and the internet the development of the Net was the result of the work of many computer pioneers from the academic, government and research sectors working cooperatively to produce a significant public resource. Both the IndyMedia and S11 sites provide useful examples of creative and effective uses of a technology when in the hands of citizens.

Inicialmente desenvolvida a partir de uma sinergia de cooperação pública, privada e civil, a internet permitiu a reformulação da dinâmica política. No entanto, está rapidamente se tornando mais e mais dirigida pelo privado. A Indymedia, uma iniciativa de tecnologias, conceitos e conhecimentos partilhados, levou adiante a tradição da qual a internet surgiu. Como Rhonda e Michael Hauben registram em sua história da Usenet e da internet, o desenvolvimento da Net foi o resultado do trabalho de muitos pioneiros da informática, dos setores acadêmico, governamental e de pesquisa que trabalhando cooperativamente para produzir um importante recurso público. Tanto a Indymedia quanto os sites S11 fornecem exemplos úteis de utilização criativa e eficaz de uma tecnologia quando nas mãos dos cidadãos. (Alex Kelly e Jason Gibson, jornalistas, tradução nossa) 
Sob o ponto de vista dos ativistas, a exaltação não deixa de ter sua justificativa. Ainda hoje, duas décadas depois, a rede Indymedia é um meio de comunicação de referência para os movimentos antiglobalização, e possui sites permanentes e de conteúdo regional em diversos países.

A rigor, cada um dos coletivos regionais da rede tem total autonomia para expressar objetivos e temáticas de interesse próprio, sendo os focos específicos relativamente diversos entre os mesmos. Mas, no geral, encontramos orientações políticas críticas aos Estados e a seus representantes, às grandes corporações (particularmente as midiáticas), à sociedade de consumo e aos desequilíbrios sócioeconômicos, culturais e ambientais a ela ligados. 


\section{2 CMI Brasil}

O coletivo brasileiro da rede, que é propriamente o objeto desta dissertação, é o Centro de Mídia Independente (CMI) Brasil, ao qual nos referiremos, daqui em diante, apenas como "CMI".

No site, atualmente, é assim que o CMI define sua política editorial:

O Centro de Mídia Independente (CMI) Brasil é uma rede anticapitalista de produtores/as de mídia autônomos/as e voluntários/as. Com o objetivo de construir uma sociedade livre, igualitária e que respeite o meio ambiente; o CMI procura garantir espaço para que qualquer pessoa, grupo (de afinidade política, de ação direta, de ativismo) e movimento social - que estejam em sintonia com esses objetivos - possam publicar sua própria versão dos fatos. Acreditamos que dessa maneira estaremos rompendo o papel de espectador(a) passivo/a e transformando a prática midiática. Para isso, o sítio do CMI funciona com um mecanismo de publicação aberta e automática, colocando no ar notícias, artigos, comentários, fotos, áudios e vídeos. Esse mecanismo rompe com a mediação do/a jornalista profissional e com a interferência de editores/as no conteúdo das matérias. As produções não são modificadas, salvo a pedido do/a autor(a), ou quando pequenas formatações são necessárias para facilitar sua exibição. São bem-vindas no CMI publicações que estejam de acordo com os princípios e objetivos da rede, como: relatos sobre o cotidiano dos/as oprimidos/as; relatos de novas formas de organização (como o Movimento Passe Livre, Movimento dos/as Trabalhadores/as Desempregados/as, as/os zapatistas no México, as/os piqueteiras/os na Argentina, as redes de economia solidária, etc.); denúncias contra o Estado e as corporações; iniciativas de comunicação independente (como rádios e TVs livres e comunitárias, murais e jornais de bairro, etc.); análises sobre a mídia; análises sobre movimentos sociais e formas de atuação política; produção audiovisual que vise à transformação da sociedade ou que retrate as realidades dos/as oprimidos/as ou a lutas dos novos movimentos. $^{12}$

\footnotetext{
${ }^{12}$ http://www.midiaindependente.org/static/policy.shtml. Acesso em 05/01/2009.
} 
Nos trechos a seguir de entrevista concedida à pesquisadora, um de seus participantes pioneiros no país, Pablo Ortellado, falou do início da rede Indymedia, do surgimento do coletivo brasileiro, e de algumas de suas características. ${ }^{13}$

\section{Conte um pouco da formação do CMI no Brasil.}

Quando o Indymedia nasceu em Seattle, muito vinculado ao movimento antiglobalização - em particular contra a OMC, em 1999 -, o objetivo inicial era bem diferente do que é atualmente. Se você pegar os primeiros documentos, a ideia era um pouco a da Ciranda da Informação, aquele grupo ligado ao Fórum Social Mundial. Era fazer um site de trabalho cooperativo, no qual diferentes veículos independentes colaborariam, sem direitos autorais, por ele ser livre, de maneira que substituísse uma cobertura concorrente por uma cobertura cooperativa. Eu poderia pegar todas as entrevistas que outros veículos fizessem e que pudessem servir para o meu veículo, e a mesma coisa com as minhas entrevistas. Ele já nasceu muito multimídia, embora em 1999, por exemplo, a possibilidade de você fazer vídeo efetivamente fosse muito pequena, porque os vídeos eram pesados e a qualidade era baixa. Mas já se deixava claro no projeto que ele poderia ter vídeo, texto, áudio e imagem - os quatro tipos de mídia.

Durante os protestos de 1999, as pessoas se apropriaram dos veículos de comunicação, e ele mudou completamente a cara. Então ele deixou de ser um projeto de jornalistas que estariam cooperando, e passou a ser um projeto no qual as pessoas seriam os verdadeiros atores. Esse foi um entendimento com que o próprio público da internet estava sinalizando. No momento em que se desenhou o site poderiam entrar apenas pessoas cadastradas. Mas, por uma opção de alguns desenvolvedores é que a característica de publicação aberta foi incorporada. (...) E sendo possível publicar abertamente, as pessoas fizeram uso maciço do site, que então deixou de ser feito por veículos de comunicação para ser feito pelas pessoas. E passou a ter um projeto próprio, com o espírito da publicação aberta. Essa foi a evolução. Isso só ficou claro em meados de novembro e dezembro de 1999. Porque o site foi ao ar poucos dias antes do protesto - o protesto foi no dia 30 de novembro - e ele passou a ser utilizado dessa maneira.

\footnotetext{
${ }^{13}$ A entrevista na íntegra se encontra no Capítulo 2.
} 
Digamos que essa consciência se formou entre dezembro de 1999 e janeiro de 2000. Imediatamente depois, o Indymedia começou a se descentralizar, mais ou menos acompanhando os protestos contra os organismos internacionais. Era um pouco a lógica do movimento naquela época, de a gente fazer encontros tentando barrar os encontros dos organismos mundiais: OMC, FMI, Banco Mundial, G8. Em cada lugar onde acontecia um desses protestos, tinha um CMI. O primeiro da América Latina, que foi o do México, era um movimento muito forte, de um dos grupos que estava ligado nessa rede de grupos autônomos mundiais que se formou na história do movimento antiglobalização. Então foi para o México, e acho que depois foi para a Bolívia, e a seguir para o Brasil.

Quando o CMI Brasil foi criado, a gente já tinha o entendimento da publicação aberta como coração do nosso projeto - isso já tinha se consolidado imediatamente após Seattle. Mas, ao mesmo tempo, o que confundia muito o projeto do CMI com o projeto do movimento antiglobalização, é que o CMI era o veículo oficial de comunicação do movimento antiglobalização. Só que esse movimento antiglobalização tinha uma ambiguidade, que era ser por um lado um novo movimento social e por outro se apresentar apenas como uma convergência de todos os movimentos. O nosso discurso em 2000 era: "nós estamos superando a fragmentação dos movimentos dos anos 60 e 70". Houve um histórico que vai do final do século XIX, até os anos 70, onde o movimento social estava atuando sob o guarda-chuva do movimento operário. Nos anos 70 ele se fragmenta com a luta das mulheres, dos negros, dos jovens, e a luta ecológica.

O movimento antiglobalização faria a convergência dessas lutas. O processo de liberalização econômica estava fazendo com que essas lutas convergissem do ponto de vista prático, porque ele afetava simultaneamente todas elas. Parecia, de longe, uma coisa sem pé nem cabeça. Mas isso era para quem estava olhando de fora, porque para a gente era exatamente isso: o processo de liberalização econômica estava afetando todos esses movimentos e permitia que a gente construísse uma plataforma comum. Na verdade, em muitas ocasiões, o movimento antiglobalização efetivamente foi isso: a convergência de todos esses movimentos. No entanto, teve uma parte dos ativistas em particular os politicamente mais ligados aos grupos autônomos - que o tomaram como sua primeira causa. Tinha gente fazendo militância antiglobalização e ponto; não estava necessariamente vinculada a algumas dessas causas que convergiam. E às vezes, dependendo de como a gente fala "movimento antiglobalização" no sentido 
estrito, estamos falando dos grupos que tomaram a liderança dos processos de 1998 até 2002. Eram grupos, do ponto de vista político, bem horizontalistas, e eram principalmente jovens urbanos, mas, dependendo do país, também grupos camponeses. O CMI também permitiu que diversos grupos que estavam atuando se encontrassem na parte de comunicação.

Em 1999, para quem estava mais ou menos envolvido no campo político, ficou claro que havia uma movimentação, que estava surgindo alguma coisa, mesmo muito antes de Seattle. No primeiro período, quem efetivamente liderou o movimento antiglobalização no mundo inteiro foram grupos de jovens urbanos que estavam ligados a uma rede chamada Ação Global dos Povos (AGP), porque foi a partir daí que nasceram os Dias de Ação Global. Era uma rede que tinha um objetivo: protestar durante os dias de encontros de organismos multilaterais, como o G8. Seriam, digamos, manifestações e ações diretas em diversas cidades do mundo pressionando contra essas instituições multilaterais. Essa estratégia que foi definida pela AGP foi o germe, na minha leitura.

Então esse era um processo que já vinha acontecendo, já tinha grupo em São Paulo se organizando nesse sentido. Nossa primeira manifestação mais séria foi no $1^{\circ}$ de maio de 2000. E depois, em 26 de setembro, foi nossa estreia mesmo, em São Paulo, com o movimento bem organizado e tal. Então, durante o ano 2000, imediatamente após Seattle, a gente teve um processo de preparação e de edição do movimento. E o CMI era uma parte disso, de uma maneira muito individualizada. Eram dois grupos, e tinha gente que estava no movimento antiglobalização, mas não estava no $\mathrm{CMI}$; mas não havia no $\mathrm{CMI}$ quem não estivesse no movimento antiglobalização.

\section{Como você definiria o CMI?}

Porque o CMI é um conjunto de projetos, ele é de difícil definição. Diria que o CMI é uma rede de mídia que busca promover a capacidade das pessoas falarem por si próprias. De maneira vaga acho que é alguma coisa assim. Quando incluímos esse conceito de publicação aberta, o site Indymedia teve mais de um milhão de acessos, no final de novembro de 1999. Enfim, foi um marco na história da comunicação quando não havia blog e outras ferramentas como hoje, em que se publica à vontade. $\mathrm{Na}$ época só havia os grandes portais, onde os analistas escreviam. Os sites pessoais eram muitos pequenos. 


\section{Que outros projetos são estes do conjunto que você falou?}

Produção de vídeo, rádio comunitária, canal web, jornal-mural, cyber café, vários. Cada coletivo tem as suas dezenas de projetos.

E qual é a relação dos movimentos sociais com o CMI? As pessoas que fazem parte de um movimento social buscam o CMI como um canal? Como funciona isso?

Ele nasceu como um veículo do movimento. Quem o fazia eram as pessoas do movimento antiglobalização no sentido estrito, aqueles que se dedicavam ao movimento antiglobalização. E era praticamente só usado pelo movimento antiglobalização. Por outro lado, ele tinha de ser a convergência. Então era tudo: o movimento feminista, movimento verde. A primeira cara do site do CMI eram três cores e três colunas: uma preta, uma vermelha e outra preta. Já era por causa de Seattle, por causa da liberdade, e do movimento ecológico. Já tinha essa ideia de unir os movimentos na própria organização estética do site. Era o nosso discurso, mas acho eu - que ele era usado de fato pelo movimento antiglobalização. Que de certa maneira era a convergência, e de certa maneira não era, porque tinha um grupo de pessoas ali que só se dedicavam ao movimento antiglobalização.

\section{Mas isso foi mudando durante o tempo?}

Foi mudando, porque quando esse movimento antiglobalização desapareceu, as pessoas se voltaram para os outros locais e aí o CMI assumiu o papel de tentar fazer, do ponto de vista da comunicação, e não do ponto de vista prático - como era a nossa plataforma no ano 2000 - essa convergência dos movimentos sociais.

\section{E o que mais você percebeu de mudanças, ao longo do tempo?}

Primeiro: o CMI é um projeto anacrônico, a meu ver, e tanto do ponto de vista social quanto do ponto de vista tecnológico. Porque quando nós nos propúnhamos a fazer a convergência dos movimentos sociais, esse pessoal estava convergindo praticamente. Eles estavam já reunidos e estavam tendo fóruns de articulação política contra o processo de liberalização econômica. Essa convergência prática não existe mais. Do ponto de vista da comunicação é um projeto, digamos, informativo e não é um projeto político mais. 
Mas o site do CMI é o único onde você vai ter, por exemplo, a luta pelo direitos animais ao lado das lutas pela causas gays ou étnicas. Não existe nenhum outro site onde essas duas coisas tenham a mesma dignidade. Mas essa convergência é uma convergência informativa. É um lugar onde você vai ver essas informações sobre tudo isso, e com dignidade. Mas esses movimentos estão convergindo, praticamente? Não. Esse projeto político faliu. E faliu quando o movimento antiglobalização, que é uma outra história, se dissolveu. Mas isso é outra coisa. Quando ele deixou de existir, esse projeto político prático desapareceu. Ele se transformou em um projeto informativo.

\section{Que valores você vê ainda no CMI?}

O CMI tem um certo histórico e uma baita visibilidade. Não tem mais ninguém nesse meio, nem do ponto de vista do número de acessos, que chegue perto do CMI. Ele tem muita visibilidade, e é um site histórico na internet, que cumpre ainda o papel de dar destaque a essa auto-publicação. Agora, ele não tem a mesma centralidade que tinha no momento original. Porque os movimentos arrumaram outros meios de autoexpressão.

Abaixo, temos um trecho da carta de apresentação do coletivo do CMI em São Paulo, em que, por proximidade, e também por ser o de maior atuação no Brasil no momento, nos focalizamos mais durante a pesquisa. O documento foi escrito na época da criação do coletivo, e nos foi fornecido por um de seus primeiros participantes.

\section{CARTA DE APRESENTAÇÃO DO COLETIVO CMI SÃO PAULO}

O coletivo CMI São Paulo é um grupo de pessoas que participa do projeto internacional do Centro de Mídia Independente. Os participantes envolvidos há mais tempo tomaram parte no processo de estabelecimento de um site nos moldes da rede global Indymedia.

Nossa organização é feita de forma horizontal, sem hierarquias. As tomadas de decisão são praticadas pela democracia direta e participativa, utilizando o consenso como meta final em todas discussões.

Nosso objetivo primário é contribuir para a democratização da mídia, com todas as implicações e desafios que isso traz. Acreditamos que a notícia deve ser produzida por pessoas e para pessoas. Procuramos em nossa atuação dar 
ênfase aos movimentos sociais de ação direta, às políticas que eles criticam e às ações que eles desenvolvem. Os princípios do coletivo são os apresentados na proposta de organização da rede CMI Brasil.

Atualmente trabalhamos em vários projetos visando nosso objetivo, dentre eles:

- Cyber café: Visando primariamente possibilitar o acesso à internet para todos que se interessem pelo projeto do cmi, mantemos o cyber café com acesso gratuito à internet. Essa iniciativa é totalmente mantida por trabalho voluntário e doações para cobrir as despesas.

- Envolvimento com movimentos sociais: Estamos discutindo atualmente formas de estabelecer um contato maior com os movimentos sociais que atuam em nossa região.

- Encontro de Mídia Alternativa: Estamos considerando a possibilidade de realizar um encontro com vários veículos de mídia alternativa, visando uma maior integração, troca de experiências e debates diversos sobre o assunto.

- Rádio: Pretendemos no futuro manter uma rádio pela internet, e como próximo passo, tentar uma associação com alguma rádio comunitária ou mesmo estabelecer nosso próprio transmissor. Atualmente o projeto está parado porque ainda não há conteúdo de áudio suficiente para manter uma rádio no ar.

- Jornal Impresso: A versão em papel das notícias do CMI é publicada quando o coletivo consegue dinheiro suficiente para uma tiragem. A distribuição é gratuita. O jornal chama-se "Ação Direta". As edições já lançadas foram temáticas. Por exemplo, houve uma edição sobre a Alca.

A grande maioria dos indivíduos que participam do coletivo atualmente é jovem e estudante. Como todos coletivos ligados à rede Indymedia, somos um coletivo sempre aberto a novos participantes.

Em junho de 2008, assistimos a uma reunião para novos voluntários do CMI São Paulo, e registramos falas dos organizadores aos participantes que também ajudam a esclarecer a proposta do grupo.

"O CMI é ligado à rede Indymedia, que surgiu nos protestos de Seattle, para fazer uma cobertura horizontal. É aberto a qualquer participante, e acho que essa é a maior força do CMI. Não tem um 'representante', um diretor, etc, que fale por nós." (Fala de voluntário em reunião) 
"O CMI Brasil é diferente dos outros países, pois é um site só para todos os coletivos regionais. Nos outros países há um site por coletivo. Mas alguns já estão adotando o mesmo modelo que a gente.” (Fala de voluntário em reunião)

"Para nos comunicarmos usamos muito email, chat e as listas dos coletivos de trabalho: editorial, de tradução, de vídeo, técnico, etc." (Fala de voluntário em reunião)

“Temos uma orientação específica, que é usar softwares livres, que são mais seguros e também por uma questão de coerência, não utilizando as ferramentas comerciais das megacorporações que lutamos contra. O conteúdo também é de livre uso e divulgação para fins não-comerciais.” (Fala de voluntário em reunião)

"Nossa política editorial não tem um objetivo único, é mais uma orientação, um princípio geral.” (Fala de voluntário em reunião)

“O trabalho voluntário aqui é aberto: não tem 'você tem que fazer só isso'. E os coletivos das cidades se organizam da maneira que querem, desde que sigam o princípio contra o capitalismo. Lembrando que o CMI é antipartidário, anticlerical e anticapitalista." (Fala de voluntário em reunião)

“O CMI não é um blog para colocar a opinião de ninguém. Não temos nada contra a pessoa divulgar o link do blog dela lá, mas nossa ideia é dar voz a quem não tem, principalmente aos movimentos sociais. Queremos também desmistificar essa ideia de que no Brasil nada acontece, de que o brasileiro é um povo passivo. Tem sim muitos movimentos acontecendo e muita repressão rolando em cima deles." (Fala de voluntário em reunião)

"[Queremos] desmistificar também o jornalismo como uma coisa exclusiva do jornalista profissional. É claro que nós também podemos melhorar nosso trabalho em várias coisas, e estamos sempre tentando isso.” (Fala de voluntário em reunião)

“Como o trabalho é voluntário, tem que ser uma coisa gostosa, o que você quer fazer. Mas há também algumas coisas que são meio chatas de fazer, só que a gente 
sabe que são tão importantes, então fazemos numa boa." (Fala de voluntário em reunião)

“Temos também outros projetos, como os jornais impressos: CMI na Rua e o Ação Direta. E temos uma idéia de fazer algumas revistas temáticas, o que ainda não foi para frente por falta de dinheiro.” (Fala de voluntário em reunião)

"Dinheiro a gente não tem, é muito difícil. Arrecadamos alguma coisa com a venda de camisetas, vídeos produzidos pelos coletivos nacionais e internacionais, ou que tenham a ver com a proposta, e a pessoa paga o quanto pode. Uma vez a Ford Fundation queria dar uma boa grana para a gente, rolou a maior discussão, mas acabou-se decidindo que não aceitaríamos, porque ia contra tudo que fazemos. Os CMIs dos países do norte, com mais dinheiro, costumam financiar os do sul. Mas no Brasil não recebemos ainda esta ajuda." (Fala de voluntário em reunião) 


\section{3 Como funciona o site do CMI}

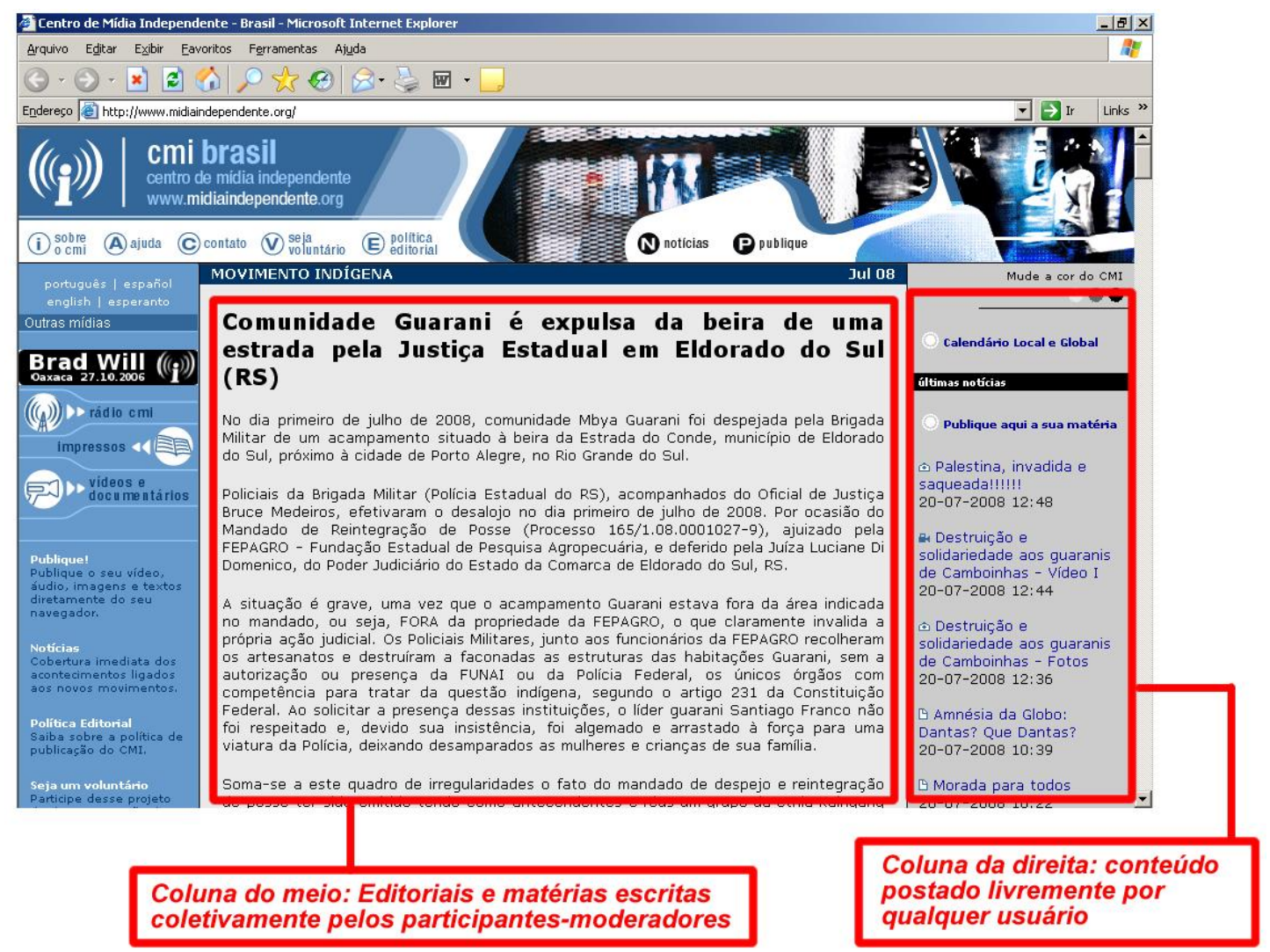

Fig. 1.1 Hierarquia de conteúdos publicados. (http://www.midiaindependente.org. Acesso em 08/07/2008)

$\mathrm{Na}$ coluna central do site do CMI encontramos os artigos publicados pelo coletivo editorial, que passam por um processo de seleção e edição conjunta pelo chamado "coletivo editorial" para ser alçado a este local de maior destaque. Na coluna da direita ficam os textos de publicação livre, aceitando-se qualquer contribuição que se relacione às temáticas listadas na política editorial. As que não se enquadrem, ou mesmo ofendam estes princípios, como, por exemplo, mensagens de teor racista e prócapitalismo não são apagadas, mas removidas por moderadores voluntários para uma seção denominada "Artigos escondidos".

O "coletivo editorial” é formado por pessoas que já atuam há algum tempo no CMI, e por um critério subjetivo - que é a confiança dos demais participantes que já tinham presença neste coletivo editorial - puderam nele entrar. O trabalho de redação ou seleção e edição de textos para a coluna central é feito quase que totalmente online, através de uma lista de emails. Apesar de apenas membros do coletivo editorial poderem participar de fato da lista, escrevendo emails, o conteúdo de suas mensagens 
é aberto, podendo ser acessado por qualquer pessoa em uma página na internet: http://lists.indymedia.org/pipermail/cmi-brasil-editorial. Ou seja: é possível acompanhar de fora o trabalho de redação e edição dos textos que são levados até a coluna central. E há a hipótese de que qualquer pessoa tenha um texto publicado nesta coluna, mesmo que ela não faça parte do coletivo editorial. Muitos textos da coluna da direita, por exemplo, acabam virando editoriais, mesmo que não tenham sido escritos por ninguém que faça parte do coletivo editorial. Se forem considerados interessantes por este grupo, e alguém de dentro dele sugerir, podem ser transferidos para a coluna central.

Também há diversos casos em que textos de pessoas que não fazem parte do coletivo editorial e nem publicaram na coluna da direita podem ser levados até a coluna central. Novamente, basta a sugestão de algum membro do coletivo editorial, e o aceite de pelo menos três outros membros - o que eles chamam de "três OKs", e que é o mesmo critério de aceitação para textos provenientes da coluna da direita ou escritos por algum membro do coletivo editorial.

O voluntário entrevistado Flecha, explica os critérios para uma pessoa entrar no coletivo editorial:

"A gente teve milhares de discussões sobre hierarquia, confiança e segurança. Já entendemos que realmente as informações com que a gente lida devem ter um sigilo maior, não por uma questão hierárquica, mas por uma questão de segurança da própria rede, para a rede se manter. Esse mês, por exemplo, já teve servidor apreendido lá no Reino Unido. Então acho que se não houvesse essa segurança, o CMI já não existiria, e já teria problemas piores. A segurança passa por uma restrição de informação. E aí você decidir quem que tem a permissão de acessar esta informação ou não. Eu diria que a maneira mais correta de fazer isso de uma forma que tente seguir ao máximo possível a horizontalidade é o coletivo editorial. É um processo de confiança, o qual quem está há mais tempo, ou quem está mais por dentro do CMI já entende. Então não está restrito a uma pauta, não está restrito a uma tendência só. A pessoa deve ter uma visão mais ampla da situação local, um pouco nacional - porque também uma pessoa saber tudo é difícil -, mas ter um enfoque maior para poder mediar essas situações de um artigo que diz respeito a Recife, por exemplo. Às vezes 
chega um artigo de Recife, e você está por dentro do que está acontecendo lá, ou então você tem que saber quem está, você tem que ter os contatos de quem está lá e peguntar: 'Isso está certo, o grupo é legal mesmo, é assim mesmo que está no artigo?' Para checar a credibilidade do artigo.

Tudo no site é na base do consenso, só que no inicio do processo a gente teve que estabelecer quando que o consenso é atingido ou não. Por exemplo, um artigo que foi publicado, e um voluntário jogou no "lixo aberto". Tem que ser consenso o artigo ficar no lixo aberto, se não for consenso o artigo permanece no site, entendeu? Se não for consenso, o artigo não vai ficar no escondido, vai ficar no lugar certo para todo mundo ver, exposto no site. E a mesma coisa com o editorial, mas com o editorial é muito mais rápido, porque já tem esse processo de confiança de que eu falei anteriormente. Normalmente, quem escreve para a coluna dos editoriais são os próprios voluntários que conhecem mais a política editorial. Já conhecem melhor a proposta do CMI, então escrevem uns editoriais mais propícios e por isso que é muito raro ter algum editorial que não vai para o ar. Por exemplo, no caso do meu primeiro editorial quando eu entrei no coletivo São Paulo, eu ainda não fazia parte da lista editorial, e eu fui fazer uma cobertura de uma manifestação anti-guerra do PSTU e depois de um grupo anarquista. Lembro que eu tirei as fotos e fiz uma proposta editorial, e eu era voluntário novo, não na lista editorial. A proposta foi barrada, mas por critérios de política. Não lembro exatamente qual foi o motivo, mas foi por não estar dentro dessa adequação à proposta CMI. Lembro que esse é um exemplo de como é importante que a pessoa faça parte do coletivo há algum tempo para entrar na lista editorial. Então foi um processo assim, em que eu fiquei até um pouco decepcionado por não ter sido aceito, mas hoje eu entendo que foi certíssimo, porque é questão de conhecer a estrutura, a política. Depois de um tempo eu até dei uma lida na proposta que eu fiz e disse: "nossa, se fosse hoje eu não teria feito assim. Se eu pudesse, deletava isto da lista no histórico" [risos]. Você chega e não entende direito como funciona, por isso que tem que ter essa confiança."

[Se não tem consenso, mas tem a maioria] a proposta é indiretamente arquivada e deixada para ser discutida em uma reunião nacional, pessoalmente.

[Se os três "OK” de pessoas da lista editorial para um artigo são atingidos, mas alguém do coletivo acha que isso não pode entrar de jeito nenhum] a pessoa tira o editorial do ar e manda email falando que não concorda por algum motivo, e aí isso vai ser discutido. Como o editorial em muitos casos trata de notícias com um tempo de 
validade, às vezes vale a pena uma discussão em cima dele, e às vezes não. Se é um editorial de algum fato, algum evento, por exemplo. No caso da inauguração do espaço Ay Carmela! $!^{14}$, a gente colocou o editorial e divulgou o evento. E isso gerou uma discussão na lista da necessidade de divulgar eventos locais em editoriais. A gente colocou um editorial, mas eu nem sei se agora o editorial está no ar ou não. Acho que ele ficou por um tempo, e até é uma proposta que eu ainda não fiz, mas em que vou pensar melhor depois: editoriais temporários. Mas enfim, gerou-se esse questionamento na lista editorial da necessidade de fazer um editorial chamando para eventos. Mas aí tem o seguinte: como você trabalha com consenso, e você sabe que consenso é difícil, às vezes você questiona aquela necessidade, aquela pauta, mas você acaba aceitando ali no momento para não travar o processo. Então a pessoa que questionou aceita. Porque você sabe que é difícil, lógico. É uma questão muito da pessoa. Então é por isso que não dá pra você colocar como administrador do site na lista de editorial qualquer voluntário que apareça (...) Você tem que saber se a pessoa tem esse bom senso, e a noção da dificuldade de trabalhar com consenso. Muitas vezes o consenso é você abdicar temporariamente daquela sua posição para discutir depois em um momento mais adequado. Então você guarda uma discussão para uma reunião nacional. Aí o que acontece? Aquele editorial em particular permanece, mas dali para diante não se faz mais editorial daquela forma. Isso de trabalhar com maioria não existe no CMI." (Trechos de entrevista com o voluntário Flecha. Íntegra no Capítulo 3)

Para manutenção da estrutura deste site, além do coletivo editorial, há diversos grupos de trabalho (manutenção técnica, tradução, produção de vídeos, contato e deliberação com coletivos internacionais e com o global, etc.), atuando em diferentes locais do Brasil e fora dele, e algumas vezes com pouco contato presencial. Alguns destes grupos mantêm uma lista de emails específica para o contato necessário às suas tarefas. Há também a lista de cada coletivo regional. O de São Paulo, que acompanhamos, realiza reuniões presenciais com um frequência no mínimo mensal. $\mathrm{Na}$ época em que acompanhamos este trabalho (entre 2008 e 2009), notamos que o

\footnotetext{
${ }^{14}$ Espaço físico gerido por grupos, coletivos e movimentos sociais, incluindo o coletivo do CMI São Paulo. Ver 15.
} 
quórum destas reuniões costuma ser baixo (de três a sete pessoas), mas as decisões eram tomadas e as tarefas encaminhadas por email, e mesmo quem não comparecia à reunião assumia algumas delas.

Entre estas tarefas estão gerenciamento financeiro, levantamento de pautas para serem sugeridas ao coletivo editorial (que é nacional), organização de eventos, apoio do CMI a algum grupo ou movimento que o tenha requerido, manutenção dos computadores e do espaço físico onde o CMI se reúne em São Paulo e promove algumas atividades.

O Espaço Ay Carmela! ${ }^{15}$ fica localizado no centro de São Paulo, e é utilizado e mantido também por outros coletivos e movimentos, como o MST, o Movimento pelo Passe Livre e a Bicicletada. No uso deste espaço fica bem clara a proposta da autogestão, que é a mesma do CMI: os grupos tanto atuam coletivamente, promovendo algumas ações e eventos conjuntos, como também o utilizam para suas atividades próprias, e não há nenhum tipo de hierarquia entre eles. Contribuem financeiramente para as despesas do local e também com mão-de-obra para manutenção. Para esta organização, há um comitê gestor de espaço, com um representante de cada coletivo que o utiliza.

Durante o período que acompanhamos a atuação do coletivo de São Paulo, notamos que boa parte de seus participantes mais atuantes (ou, pelo menos, que compareciam mais aos encontros presenciais e escreviam emails para a lista CMI São Paulo) tinham conexão maior com alguns movimentos sociais específicos: o movimento dos sem-teto - em particular o Fórum Centro-Vivo, que realiza ocupações em terrenos e edifícios abandonados da cidade; o Movimento pelo Passe Livre; o Movimento do Software Livre; e movimentos que defendem um uso político libertário da tecnologia, como o grupo Saravá ${ }^{16}$. A maioria dos participantes com quem tivemos contato também era vegetariana e defendia a causa da libertação animal. Em mais de

\footnotetext{
15 “O Espaço Ay Carmela! é um centro político-cultural autogestionário mantido por grupos, movimentos e indivíduos autônomos da cidade de São Paulo. Um lugar de construção de ações e conhecimentos coletivos, além de um pólo de produção, reunião e dispersão de informações, saberes e transformações. O Ay Carmela! é localizado no centro de São Paulo, próximo ao marco zero. E é mais uma forma de afirmar que o centro é nosso, das pessoas, de quem vive e circula por essa cidade e não do capital, das corporações ou do estado". (http://ay-carmela.birosca.org/Sobre. Acesso em 23/03/2010).
}

\footnotetext{
${ }^{16}$ A proposta deste coletivo pode ser consultada em seu site na internet: http://www.sarava.org. Acesso
} em 23/03/2010. 
uma ocasião participamos de eventos como almoços, jantares, exibição de filmes e festas cujo cardápio era sempre vegetariano.

Os itens a seguir, bem como as entrevistas realizadas com estes participantes mostrarão com mais detalhes as características deste grupo e de seu trabalho.

\section{Projetos múltiplos}

Conforme pontua Burguer (2004, p.14) o site não é um projeto do CMI exclusivamente ligado à internet, mas uma ponte entre a alta tecnologia e as tecnologias tradicionais de mídia, em particular rádio e jornal. Procura-se aliar as possibilidades técnicas da internet à difusão de informações por meios tradicionais. Arquivos de áudio hospedados no site são posteriormente veiculados em rádios livres e comunitárias. Coletivos também produzem boletins de notícias que são enviados para rádios, que por sua vez os utilizam em noticiários radiofônicos comunitários. $\mathrm{O}$ mesmo é feito na confecção de jornais impressos tradicionais, como o Ação Direta, ou jornais-poste como o CMI na Rua ${ }^{17}$ e O POSTe.

O CMI produz, ainda, documentários em vídeo, a exemplo de "Não começou em Seattle, não vai terminar em Québec" (sobre protestos contra a ALCA em São Paulo), “Anita Garibaldi” (sobre a maior ocupação urbana do Brasil), "Repórteres populares" (sobre a formação de repórteres em movimentos sociais), "Curtas pela democratização dos meios de comunicação", "Brad Will: uma noite nas barricadas (sobre a vida e a morte de um ativista que filmava a insurgência indígena em Oaxaca, no México), entre outros vídeos diversos com cobertura de manifestações e atos. Alguns são disponibilizados online, e outros comercializados, sendo o dinheiro arrecadado "usado na produção de novos vídeos, manutenção de equipamentos como filmadoras, gravadores, para compra de fitas de gravação, cópias de cartazes etc" ${ }^{\text {18 }}$.

\footnotetext{
${ }^{17}$ Anexos 2,3 e 4.

${ }^{18} \mathrm{http}$ ://www.midiaindependente.org/pt/blue/static/video.shtml. Acesso em 12/11/2009
} 


\section{Capítulo 2}

\section{Quem faz a mídia no CMI - a coluna da direita}

Entramos agora na proposta central desta pesquisa, que é tentar traçar um perfil dos usuários do CMI. Tanto aqueles que só postam conteúdo na parte aberta do site, sem uma participação mais ativa, quanto dos voluntários que mantêm o projeto e que já começamos a esboçar no capítulo anterior a partir da análise do discurso geral do grupo de voluntários e organizadores. Neste capítulo abordaremos o primeiro grupo.

\subsection{A coluna da direita}

Inicialmente, abordaremos o perfil do usuário da chamada "coluna da direita" do site do CMI, que permite a publicação por qualquer pessoa de textos, fotos e vídeos. A princípio, o material publicado só pode ser removido pelos voluntários moderadores do site deste local no caso de ferirem a política editorial do mesmo, exposta no Capítulo 1.

Por esta relativa liberdade de publicação o conteúdo da coluna da direita difere muito da coluna central, que tem um esquema de moderação mais rigoroso e complexo, ainda que, segundo os organizadores do site, qualquer pessoa que desejar ter um texto (chamado de "editorial") lá publicado tenha essa possibilidade, desde que siga alguns procedimentos e seja aprovado, de maneira consensual, pelo coletivo.

A tabela a seguir, organizada por voluntários do CMI, demonstra a quantidade de publicações feitas no site desde sua criação, em 2000, até o ano de $2009 .{ }^{19}$

\footnotetext{
19 "Publicação aberta": postagens na coluna da direita; “editoriais": postagens na coluna central; "lixo aberto": postagens removidas para a seção "Artigos escondidos", por estarem em desacordo com a política editorial, mas que ficam disponíveis para leitura; "lixo fechado": postagens removidas, por estarem em desacordo com a política editorial, e que não ficam disponíveis para leitura.
} 


\begin{tabular}{|c|c|c|c|c|c|c|c|c|c|c|}
\hline & $2000 / 2001$ & 2002 & 2003 & 2004 & 2005 & 2006 & 2007 & 2008 & 2009 & Total \\
\hline publicacao aberta & 4454 & 7793 & 12598 & 11827 & 14520 & 12595 & 13317 & 13871 & 12221 & 103196 \\
\hline editoriais & 112 & 266 & 445 & 272 & 408 & 601 & 419 & 264 & 205 & 2992 \\
\hline lixo aberto & 8 & 243 & 2172 & 6638 & 9110 & 2437 & 6521 & 2441 & 3170 & 32740 \\
\hline |ixo fechado & 1 & 6 & 79 & 233 & 659 & 613 & 3815 & 826 & 735 & 6967 \\
\hline & & & & & & & & & Total de Artigos & 145895 \\
\hline
\end{tabular}

Tab. 2.1 Total de postagens desde a criação do site do CMI Brasil.

Analisando o gráfico abaixo, relativo a estes quase dez anos, feito a partir da tabela, fica claro o peso da seção de publicação aberta, na coluna da direita, quando considerado o montante de publicações.

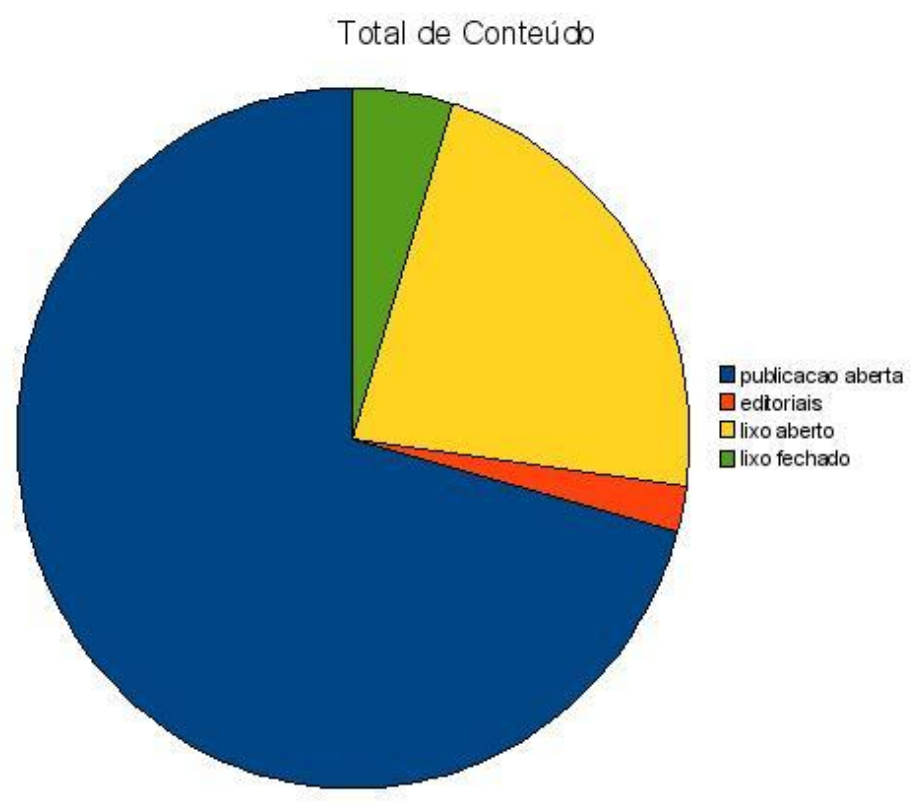

Fig. 2.1 Gráfico comparativo de postagens por seção

\subsubsection{Metodologia - pesquisa com usuários da coluna da direita}

A pesquisa empírica empreendida nos forneceu alguns dados tanto sobre as características dos usuários da coluna direita quanto sobre o conteúdo de suas postagens. As postagens, totalizando 487, foram selecionadas aleatoriamente, de 5 (mínimo) a 13 (máximo) por dia, durante 70 dias (29/11/2007 a 06/02/2008, excluídos dois dias deste ínterim em que não foram localizadas postagens no arquivo, perdidas por problemas técnicos do servidor do site). O único critério é que fossem escritas em português e divulgassem um email de contato do autor. Classificamos as postagens por "assunto" e por "formato" (gênero/estilo do texto), e enviamos um questionário 
por email para seu os autores. Foram escolhidas postagens feitas em horários variados, para evitar distorções em função de usuários que postam sempre em um horário, e também foram consideradas postagens de mesmos usuários que subiram mais de um texto no período. Apesar de não ter sido enviado mais de um questionário por pessoa, isto foi necessário para não produzir alterações na contabilização de tipo de conteúdo e temáticas mais frequentes.

\section{Sobre a categoria "assunto"}

Para os fins dessa pesquisa, os assuntos foram categorizados de maneira mais ou menos geral, já que cada um deles inclui vários subtemas e nuances. A ideia foi associá-los em grupos de afinidade para averiguar qual a preponderância temática. Ressalte-se que esta classificação leva um bom grau de subjetividade, tendo sido uma escolha particular para esta pesquisa. Mais uma observação: algumas postagens poderiam ser incluídas em mais de um assunto, casos em que a pesquisadora tentou avaliar qual era o assunto predominante.

A seguir, explicitamos os subtemas que incluímos dentro de cada categoria "assunto", dando alguns exemplos de postagens ou trechos de postagens que podem clarear as definições propostas. 
- Problemas sociais: qualquer postagem que noticie, discuta, critique ou denuncie problemáticas sociais que incluam as questões de moradia, saúde, educação, trabalho, violência, exploração econômica dos grupos mais favorecidos sobre os menos, questão agrária, distribuição de renda, desemprego, pobreza. Também inclui divulgação de eventos e ações relacionados e de grupos ou movimentos sociais que atuem nestas áreas.

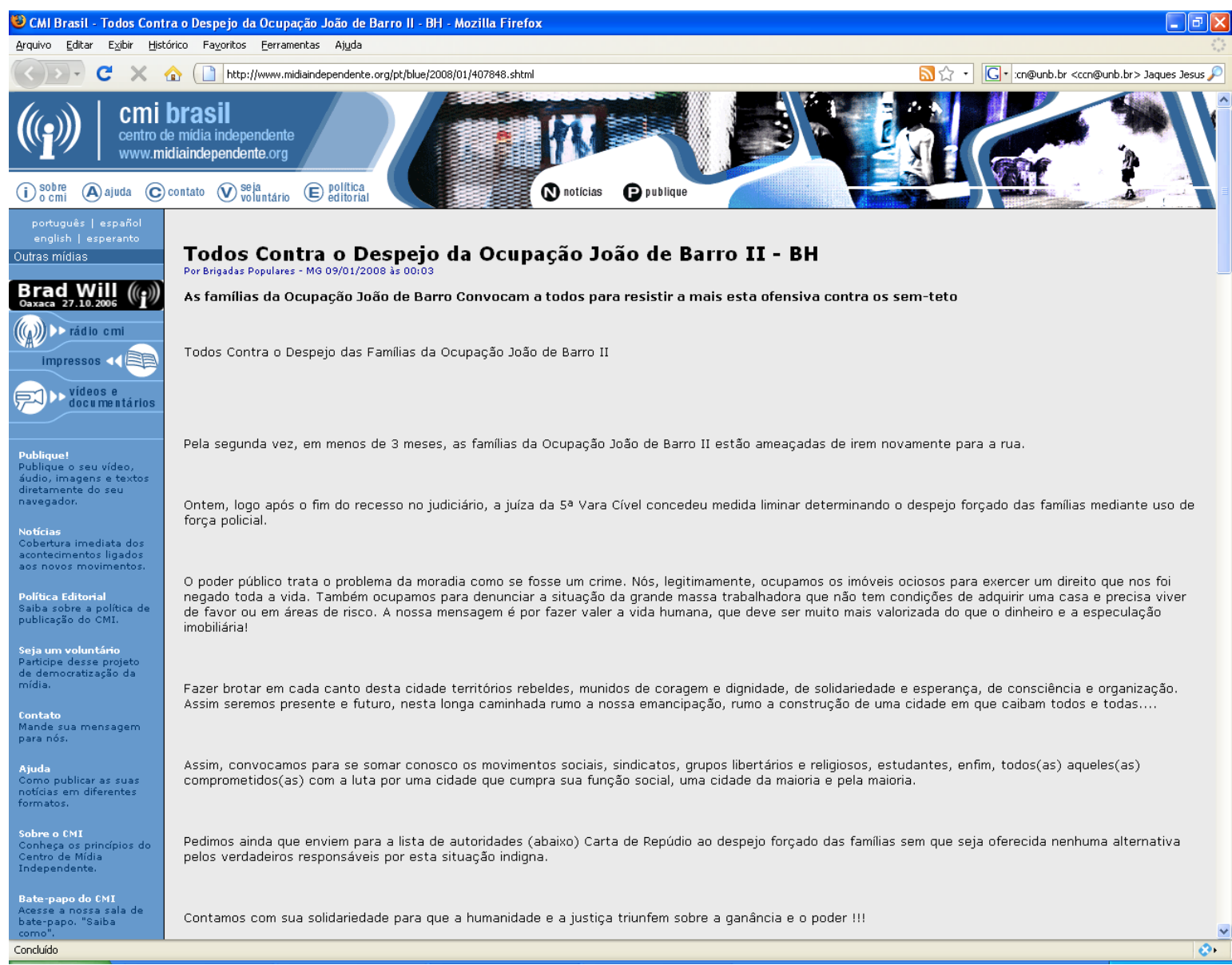

Fig. 2.2 Assunto: Problemas sociais 


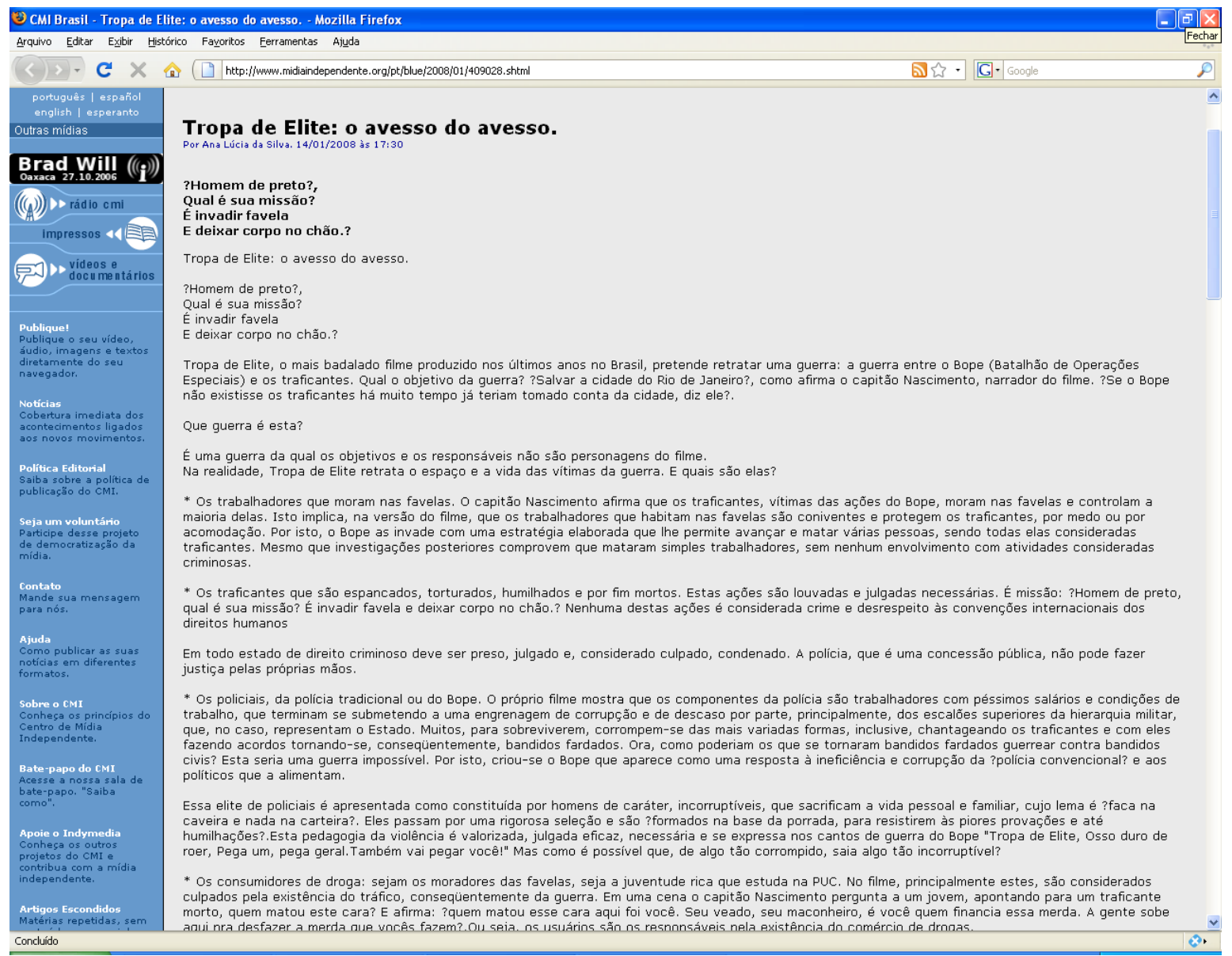

Fig. 2.3 Assunto: Problemas sociais 
- Problemas ambientais: qualquer postagem que noticie, discuta, critique, denuncie situações de degradação ambiental. Também inclui divulgação de eventos e ações relacionados e de grupos ou movimentos sociais que atuem nesta área.

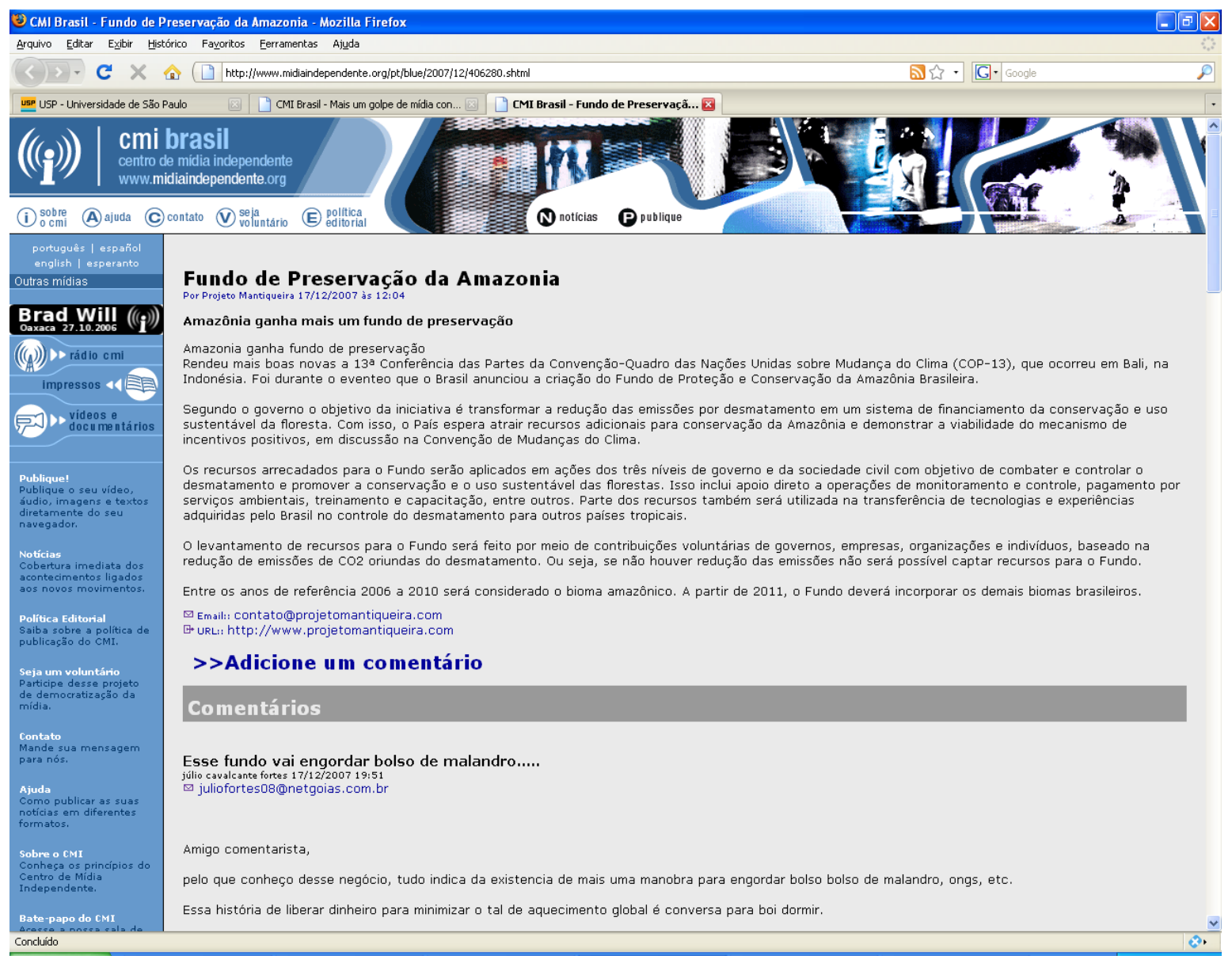

Fig. 2.4 Assunto: Problemas ambientais 


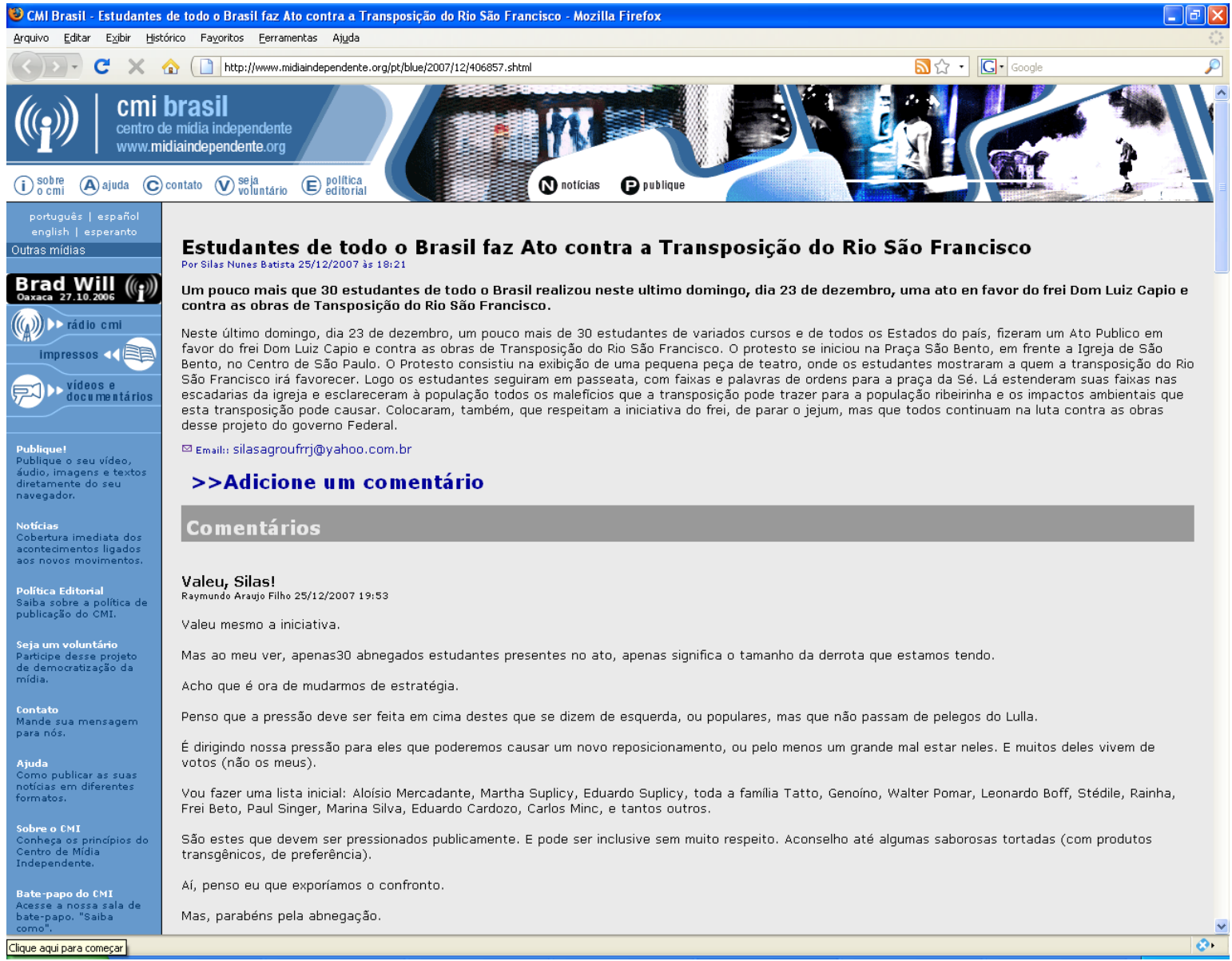

Fig. 2.5 Assunto: Problemas ambientais 
- Movimento pela libertação animal: qualquer postagem que noticie, discuta, critique, denuncie situações de exploração de animais. Também inclui divulgação de eventos e ações relacionados e de grupos ou movimentos sociais que atuem nesta área.

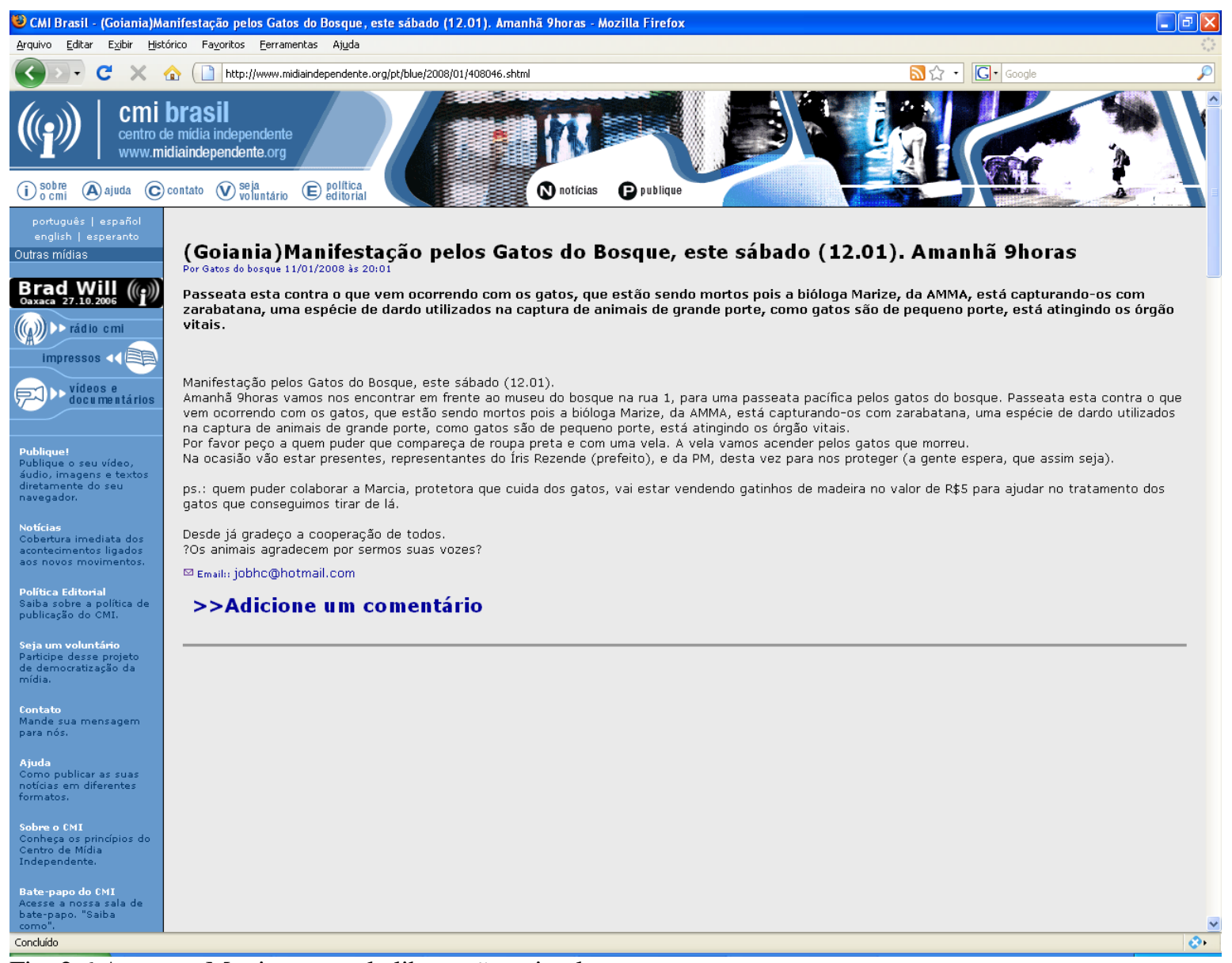

Fig. 2.6 Assunto: Movimento pela libertação animal 


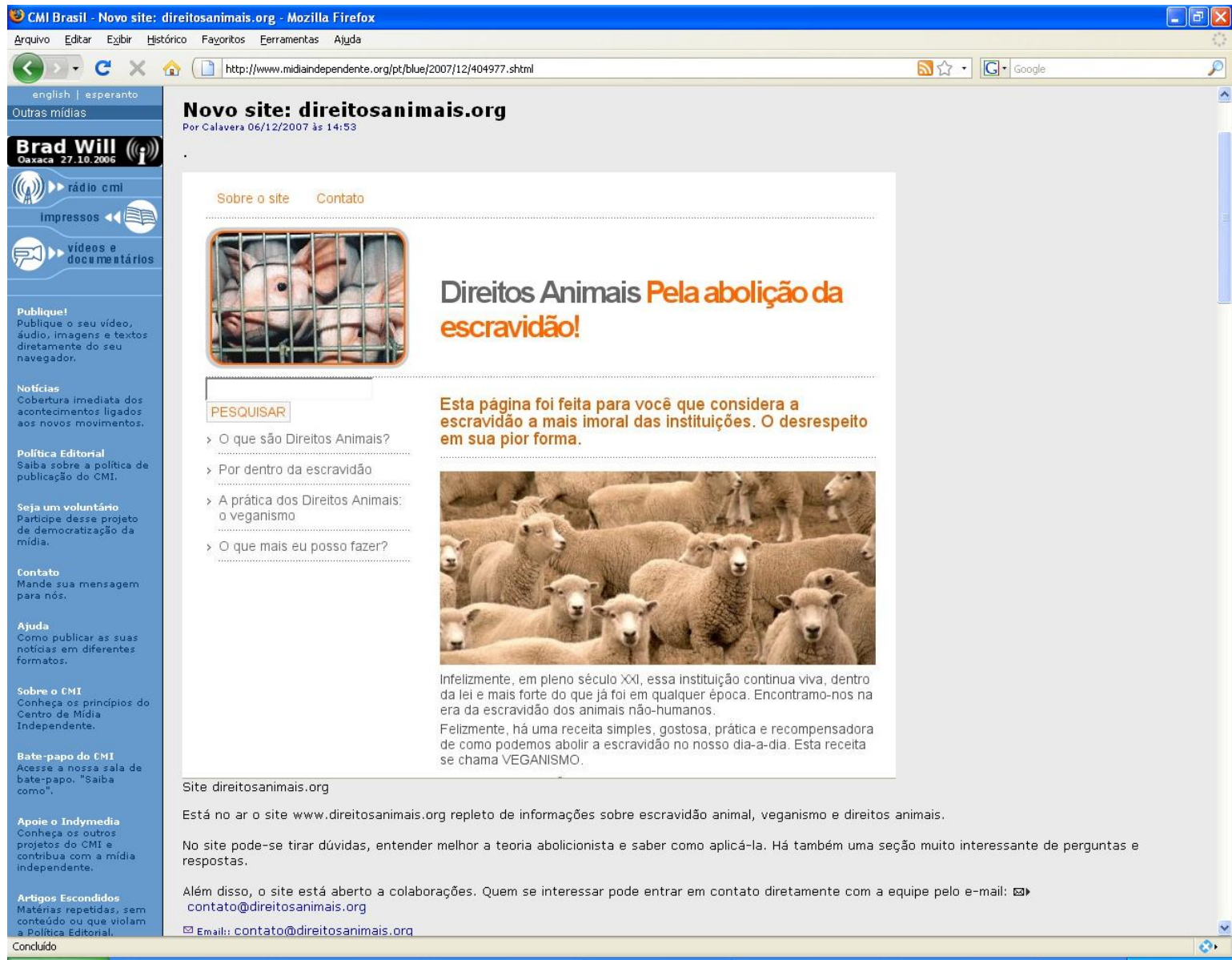

Fig. 2.7 Assunto: Movimento pela libertação animal 
- Direitos de minorias: qualquer postagem que noticie, discuta, critique, ou denuncie situações de discriminação e/ou desrespeito aos direitos de minorias, ou que promova as chamadas ações afirmativas e de exaltação da diversidade étnica. Também inclui divulgação de eventos e ações relacionados e de grupos ou movimentos sociais que atuem nesta área. Pela recorrência de dois subtemas distintos, foi possível dividir esta categoria em Direitos de minorias étnicas (negros, indígenas, e grupos étnicos minoritários em geral) e Direitos de minorias sexuais (GLBT e mulheres).

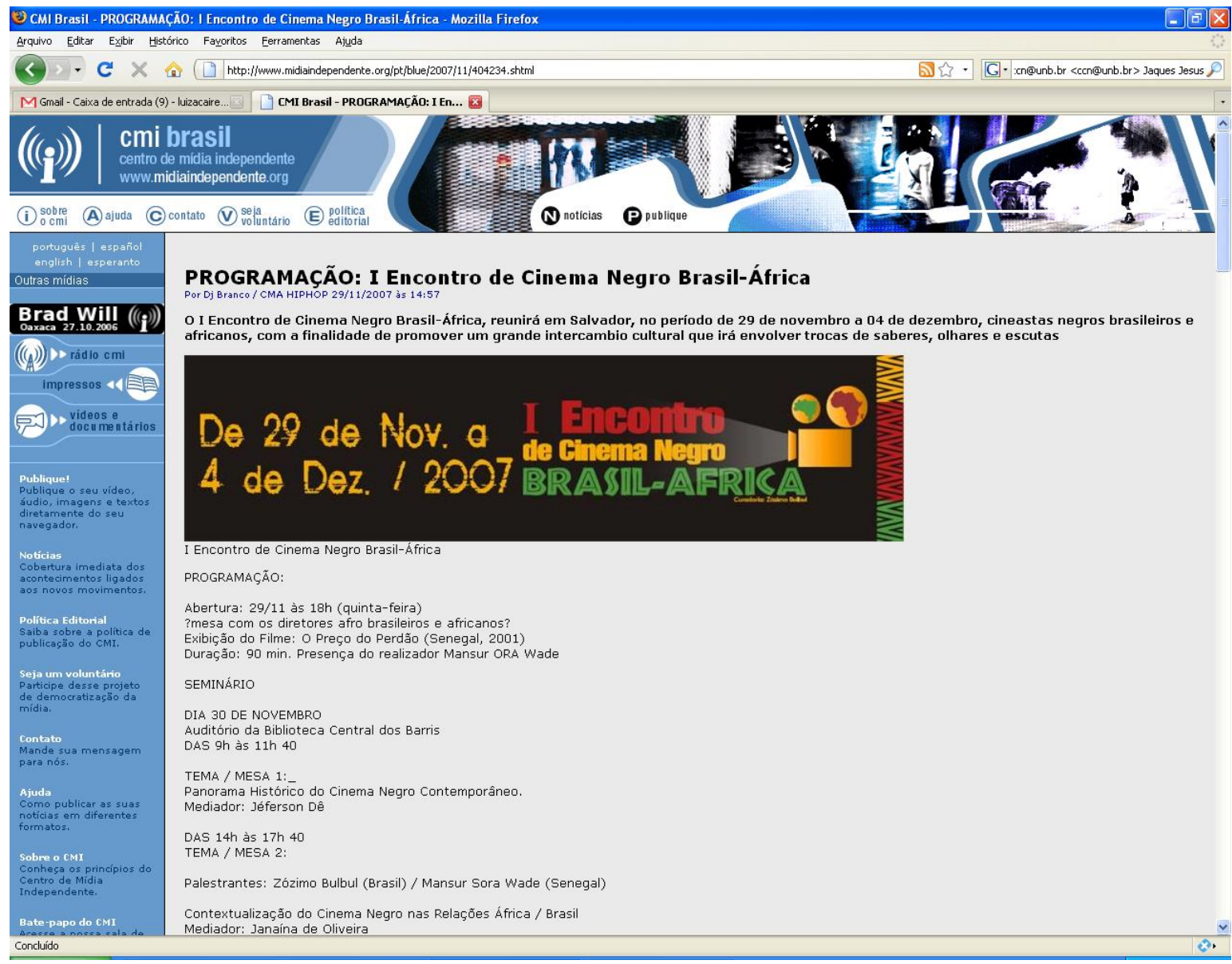

Fig. 2.8 Assunto: Direitos de minorias étnicas 


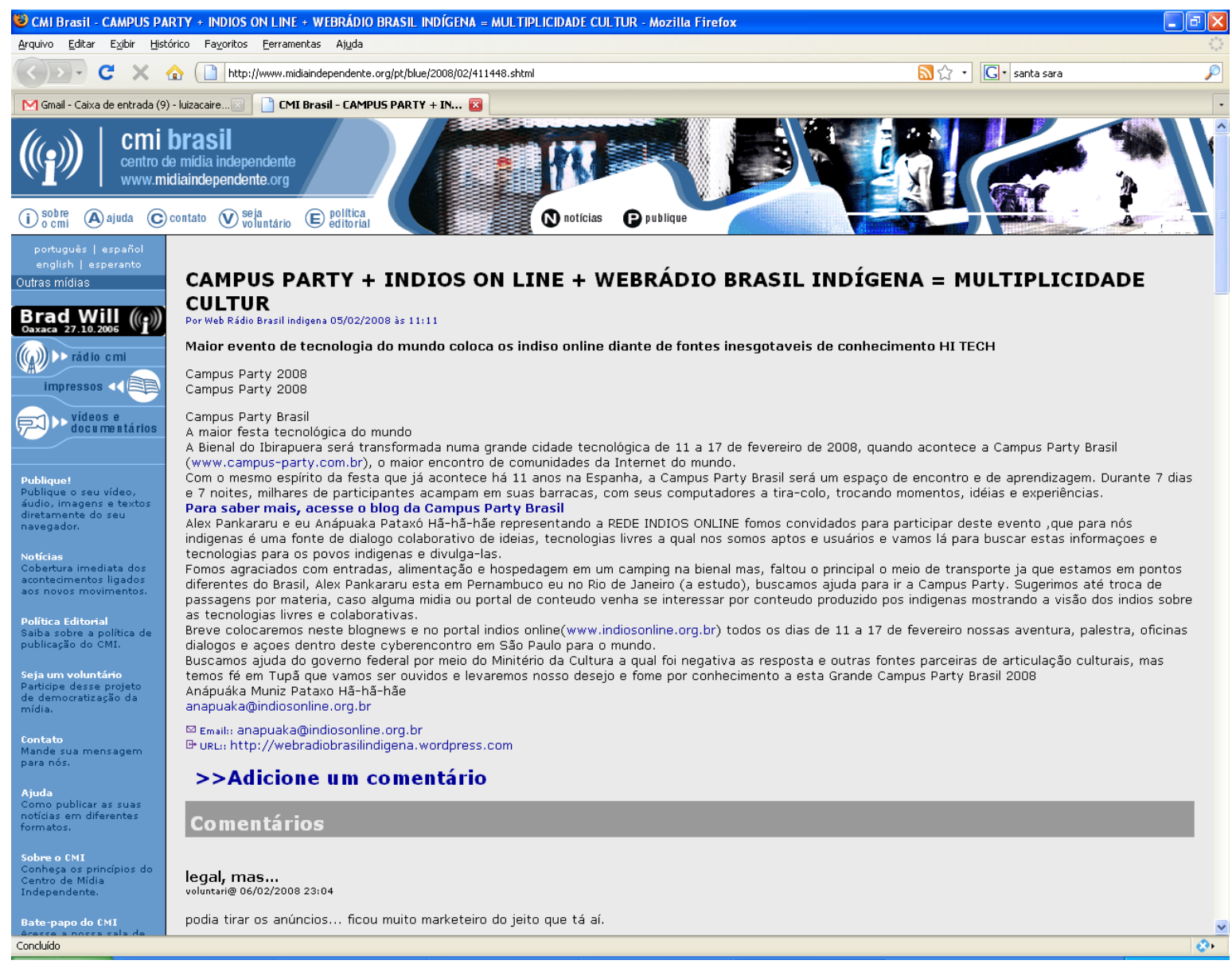

Fig. 2.9 Assunto: Direitos de minorias étnicas 


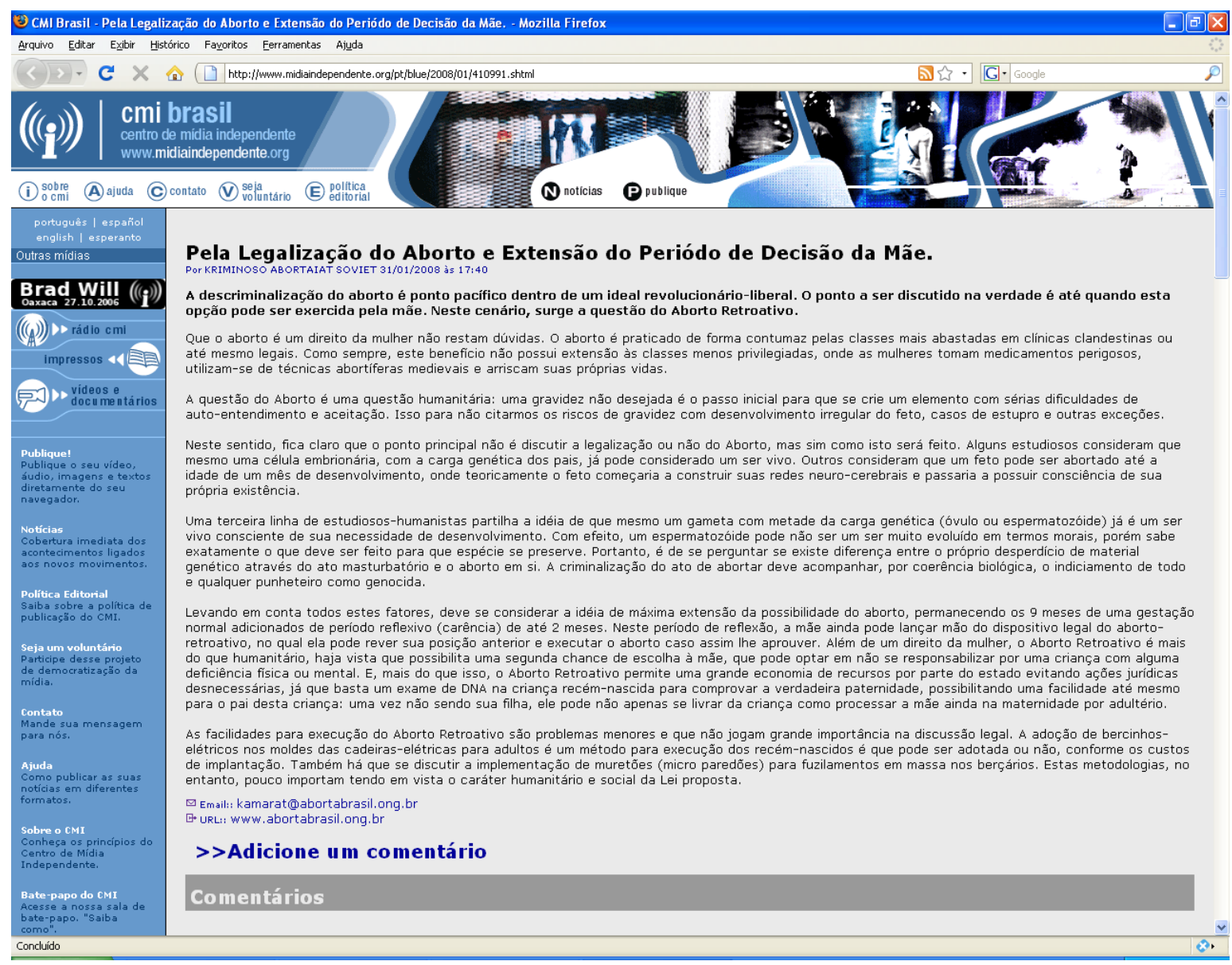

Fig. 2.10 Assunto: Direitos de minorias sexuais 
Arquivo Editar Exibir Histórice Fayoritos Eerramentas Aiuda

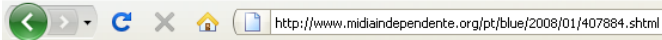

((()) $)$ cmi brasil

(i) sobre (A) ajuda (C) contato (V) voluntario (E) $\begin{gathered}\text { solitica } \\ \text { editorial }\end{gathered}$

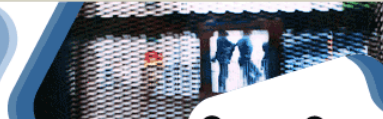

english I esperanto

Outras midias

$\underset{\text { Oaxaca 27.10.2006 }}{\text { Brad Will }}(($ p) )

\section{Licença Gala para GLBT em Diadema-SP}

((A)) $D \gg$ rádio cmi

Impressos 4 每目

A Prefeitura Municipal de Diadema-SP deu "licença gala" para sua funcionária quando esta oficializou sua relação com sua companheira! Este é o primeiro caso nesta prefeitura, que aventou também rever o estatuto para real equiparação de direitos!

Mãos unidas

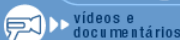

Costas e canto

Publique!
Publique o sen

No dia 20 de outubro de 2007 eu e minha companheira, com a qual compartilho a casa, a cama, a família, os afetos, enfim, a vida, assinamos o "Contrato de Convivência Homoafetiva", oficializando assim nossa relação! Nós, como muitas outras pessoas neste país, não temos o direito de nos casar. E o máximo que podemos fazer e assinar um contrato de união estavel e registrá-la em cartorio.

áudio, imagens e te
diretamente do seu
navegagdor.

Noticias

O Brasil, sendo um país declaradamente democrático e laico, infelizmente ainda se contradiz quando não dá a seus cidadãos direitos iguais para todos. Ao se casar o casal formado pessoas de sexos diferentes acessa inúmeros beneficios, que são negados aos casais do mesmo sexo(*). Sendo assim, ainda que conseguíssemos acessar um único beneficio, já seria uma conquista na busca por um mundo mais justo.

abcertura imediata dos
acostecimentos ligados
oos novos movimentos.

Politica Editorial

Quando decidimos oficializar nossa relação sabíamos das muitas dificuldades e nem cogitávamos a possibilidade de uma licença posterior ao dia do casamento, porquê não poder desfrutar de um beneficio como todos os demais funcionários públicos! Conversei com minha companheira e resolvemos que iríamos tentar

Saiba sobre a politica de
publicasăo do cMI.

Seja um voluntário
Participe desse projet

Procurei informações no ?Estatuto dos Servidores Públicos do Município de Diadema?, mas esse não ajudou. Algumas pessoas que trabalham na área de Recursos Humanos $(\mathrm{RH})$ da Prefeitura foram consultadas, mas também não sabiam como me orientar neste processo, pois esse seria o primeiro caso.

A única certeza de todos durante essas conversas era que proceder igual a outros funcionários que tiveram sua relação oficializada, mas com o nome de casamento, seria pôr em risco meu salário e meu emprego. Poderiam ser consideradas 08 (oito) "faltas injustificadas". Ou seja, quando alguns cidadãos se
unem, podem ter a licença gala, que seria uma licença para ?pompa; solenidade; regozijo; festa?, enquanto outras pessoas podem ter esse momento tăo feliz

contato interpretado como ?ausência sem motivo; descuido injustificado?.

Assim, procurei o Sindicato dos Funcionários Públicos de Diadema (Sindema). Segundo a diretoria, o mais prudente seria pôr a administração a par da solicitação que chegaria a eles: solicitaçăo de ?licença gala? por uma funcionaria que oficializou sua relação com outra mulher. Frente a tal dado, se a advogado na lista das providências do casório, junto ao bolo, flores e velas.

Como publicar as suas
noticias em diferentes

noticias em diferentes
formatos.

Sobre o CMI

centro de Midia
Independente.

o Sindema, apesar de abarrotado com entraves da pós-greve deste ano, se dispôs a fazer o delicado diálogo com a Prefeitura. O principal argumento era que Instituto de Previdência de Diadema (IPRED) já reconhecia os casais do mesmo sexo desde 2005. A administração então, não só se comprometeu a aceitar ?licença gala? da funcionaria, com a

Fig. 2.11 Assunto: Direitos de minorias sexuais 
- Política (geral): discussões teóricas e conceituais mais gerais sobre política, ideologia, regimes econômicos, críticas/definições de capitalismo, definições de anarquismo, socialismo, comunismo, blocos ideológicos e comportamentos adotados como posturas política. Algumas vezes contextualizam época e lugar dos problemas tratados, mas não citam esferas políticas específicas ou não se tratam de questões diretamente relacionadas à atualidade. Uma observação a ser feita é que tais postagens, por falarem de política mais abstratamente ou citando acontecimentos históricos e teorias, entraram praticamente todas na classificação de texto texto opinativo, exceto quando se tratava da divulgação de um evento para debater política, por exemplo, que entrava como notícia ou notícia de movimento ou organização.

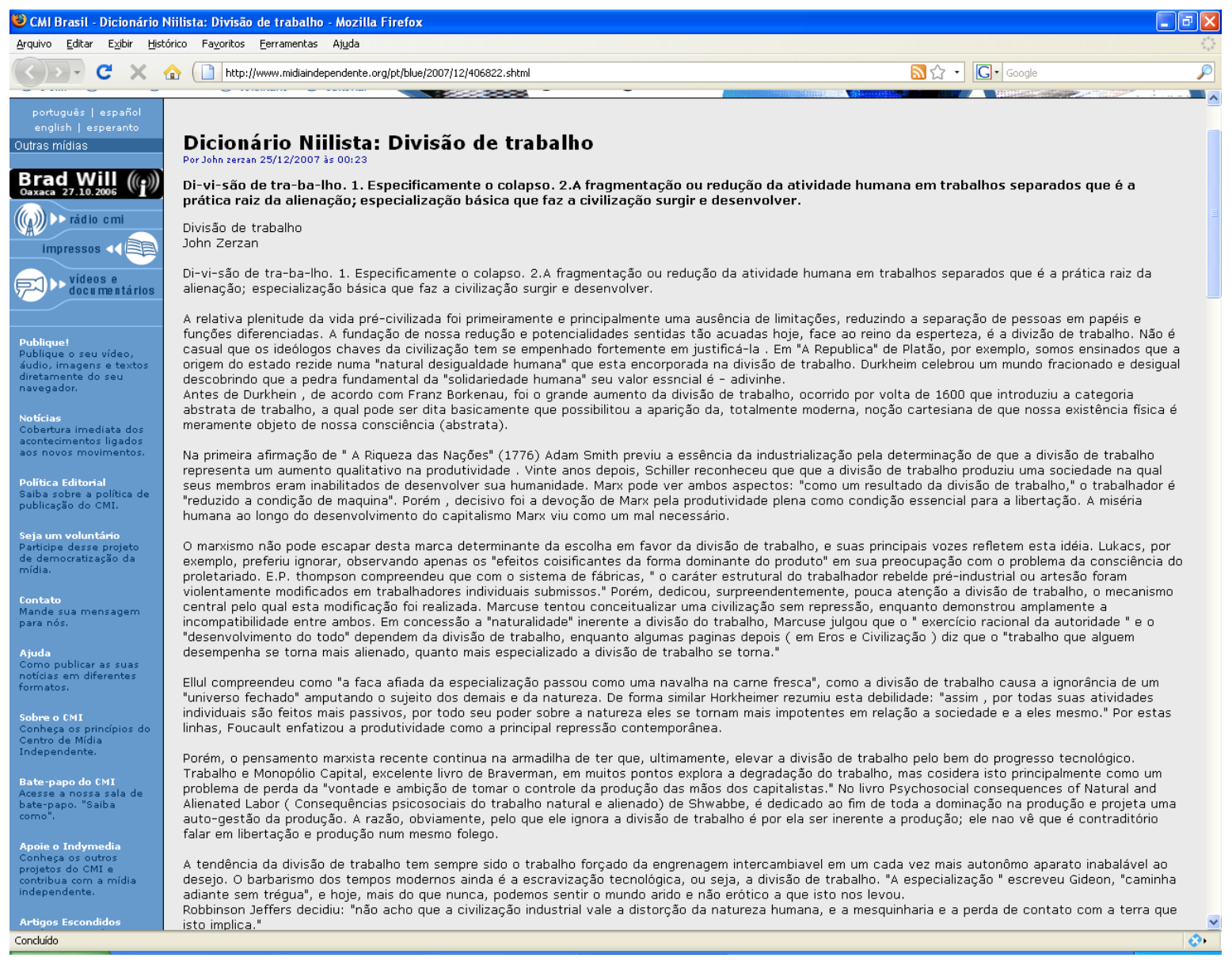

Fig. 2.12 Assunto: Política (geral) 
Arquivo Editar Exibir Histórico Fayoritos Ferramentas Aiud

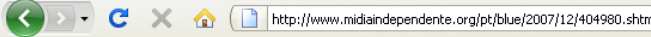

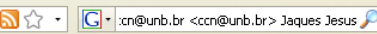

M Gmail - Caixa de entrada (9) - luizacaire... [ CMI Brasil - Outubro/90: Alec Nove $₫$

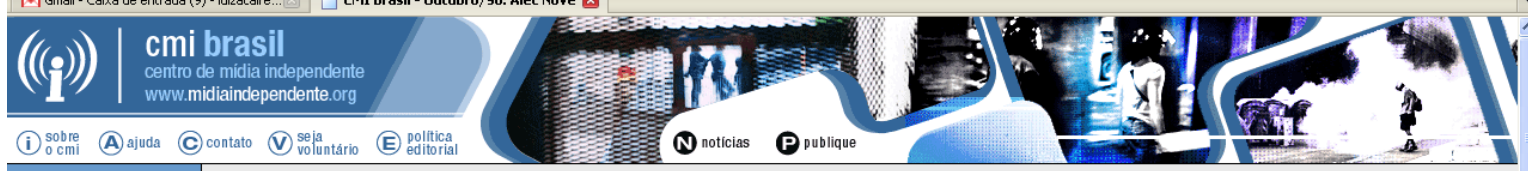

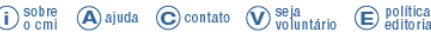

Outubro/90: Alec Nove

english | espe

$\left.\underset{\text { Oaxaca 27.10.2006 }}{\text { Brad Will }}\left(()^{2}\right)\right)$

((Q))) $\gg \gg$ rádio cmi

Impressos 4 雷

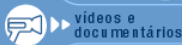

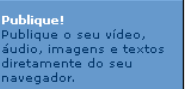

Cobertura imediata dos
contecimentos ligados

Política Editorial
Saiba sobre a polite

Saiba sobre a política
publicaşäo do cMl.

Seja um voluntário
Participe desse proje

Participe desse projeto
de democratizaçăo da

Contato
Marde sua mensagem
para nós.

Como publicar as suas
noticias em diferentes

formatos.

Sobre o CMI

Conhesa os prip
Centro de Midi
Independente.

ate-papo do CM Concluido Nós do Blog Na Prática a Teoria é Outra estamos publicando a série Outubro/90, uma série de resenhas de obras importantes sobre a revolução
de Outubro, que está completando 90 anos esse ano.

Outubro/90: História Econômica da URSS, de Alec Nove

Se você não tiver tempo e quiser ler um só livro sobre a URSS, leia esse. Vamos comentar para dar uma resumidazinha do processo todo, a ser discutido em outros posts.

Olivro da uma geralzinha sobre o desenvolvimento da Russia antes da Revoluçăo, a roubada que foi para o czarismo entrar na guerra, e o estado de desagregaça em que se encontrava a sociedade russa quando mela duzia de bolcheviques consegulu tomar o poder em um pais daquele tamanho. Frase: ?se um sujeito aromba uma porta com um unico chute, algum credito deve ser dado à porta?. Porta firme não quebra com um chute.

Nove descreve bem o comunismo de guerra, fase que vai de pouco depois da revolução até mais ou menos o fim da guerra civil, marcada por uma tentativa de estatização total da economia que deu grotescamente errado, com colapso da produção e crise de fome. Na verdade, o que se vê é que, quando os
bolcheviques diziam que acabariam com a moeda, estavam transformando a necessidade em virtude: eles não sabiam era como acabar com a inflação.

Segue-se a NEP, um recuo estratégico em que Lenin readmite as relações de mercado, com propriedade estatal na indústria, mas propriedade privada no campo (que os camponeses tomaram na marra dos antigos senhores e depois garantiram na marra contra os bolcheviques, até que o Stalin foi lá e matou eles todos)

Chegamos então a um novo agravamento da chamada ?crise das tesouras?: as tesouras são, em um gráfico, o preço dos bens agrícolas e dos bens industriais. Como a agricultura se desenvolveu bem mais, seus preços carram bem mais, a tesoura abriu, e surgiu o seguinte problema; pra que os camponeses Entinuar proço razoavel? Melhor voltar a produzir para a própria subsistência.

[os economistas lendo isso estão pensando: porque não importar bens industriais baratos, porque não derrubar os entraves à concorrência na industria; lembrem-se, estamos falando de um regime comunista ainda entusiasmado de ter vencido]

No livro do Nove vocês vão ver vários dirigentes propondo deixar o campo se desenvolver mais livremente e taxá-lo, investindo essa grana na indústria: diferentes versões dessa proposta circularam pela Rússia desde a época do czarismo.

Mas é claro que você também podia ir lá roubar tudo que os camponeses produziram e escravizar quem não morresse de fome, que foi o que o Stalin fez: a coletivização começa e progride desordenadamente, como confiscos de grãos, e depois vira uma competição de lealdade ideológica entre os comissários e burocratas, que não querem parecer ?fracos? diante dos camponeses. O nivel de alucinação disso é tão grande que o próprio Stalin escreve, no meio do processo, um artigo dizendo que alguns camaradas haviam ficado ?tontos com o sucesso? e cometido, enfim, alguns excessos. Que beleza.

Mas o melhor ponto do Nove é o debate sobre a industrialização e planificação. Ele reconstitui o debate dos excelentes técnicos soviéticos, divididos entre as ir) e como o primeiro plano quinquenal comeca qenético e termina alucinadamente teleolóqico (quem que ia discordar das revisões do plano para cima e ser

Fig. 2.13 Assunto: Política (geral) 
Arquivo Editar Exibir Histórico Fayoritos Eerramentas Ajudd

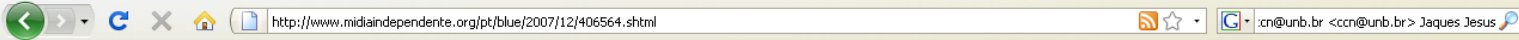

$\times$

english | esperart

Brad Will ((pi))

\section{Futuro Primitivo}

\section{$(((\mathbb{A}))) D r$ rádio cmi}

Ainda se invoca ao "homem das cavernas" e ?Neanderthal" para nos lembrar onde estaríamos sem a religião, o Estado e os trabalhos forçados. A Richard Lee e Marshall Sahlins.

E) $\gg$ videos e ecumentários

A divisão do trabalho, que tanto contribuiu para nos submergir na crise global de nosso tempo, atua cotidianamente para impedir-nos de compreender a origen do horror atual. Mary Lecron Foster (1990) e outros académicos afirmam, com muito eufemismo, que, hoje em dia, a antropologia esta "ameaçada por uma fragmentação grave e destrutiva". A voz de Shanks e Tilley (1987) faz eco de um problema similar "o objetivo da arqueologia não e somente interpretar o limitam a perspectiva e a profundidade da visão necessária que permitiriam uma reconstrução como esta. Em termos das origens e do desenvolvimento da humanidade, o leque de disciplinas e sub-disciplinas cada dia mais ramificado -antropologia, arqueologia, paleontologia, etnologia, paleobotânica,
etno-antropologia, etc., etc. - refletem a restrição, o efeito mutilador que a civilizaçẫo personificou desde o seu começo.

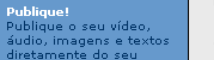

A literatura especializada pode, apesar de tudo, proporcionar uma idéia altamente apreciável, com a condição de abordá-la com método e consciência propriada, com a condição de deter a decisão de ultrapassar seus limites. De fato as deficiências no pensamento ortodoxo correspondem às exigências de uma sociedade cada vez mais frustrante. A insatisfação com a vida contemporânea se transforma em desconfiança frente às mentiras oficiais que servem para exaustivamente a renúncia e a submissão que caracterizam a vida moderna pela "natureza humana". Assim mesmo, o limite de nossa existência pré-civilizada, feita de privaçóes, de brutalidade e de ignorância acaba por fazer aparecer a autoridade como um beneficio que nos salva da selvageria. Ainda se invoca ao "homem das cavernas" e ?Neanderthal" para nos lembrar onde estaríamos sem a religião, o Estado e os trabalhos forçados.

Cobertura imediata dos
aconterimentos ligados
wos nowos nowinatos.

Politica Editorial

Porém, esta visão ideológica de nosso passado foi radicalmente modificada no curso das últimas décadas graças ao trabalho de universitários como Richard Lee e Marshall Sahlins. Têm-se assistido a uma mudança quase completa na ortodoxia antropológica de importantes consequeências. Admite-se a partir de agora que antes da domesticação, antes da invenção da agricultura, a existência humana passava essencialmente no ócio, que descansava na intimid natureza, sobre uma sabedoria sensual, fonte de igualdade entre sexos e de boa saúde corporal. II
aproximadamente dois milhões de anos, antes de nossa submissão aos sacerdotes, reis e patrốes.

Recentemente se fez outra revelação surpreendente, ligada à primeira e dando-lhe outra amplitude, que mostra quem fomos e o que nós poderiamos ser. 0 principal motivo de rejeição às novas descriç̃óes da vida dos caçadores-recolhedores consiste, em considerar este modo de vida com condescência, como 0
máximo a que podia chegar a espécie nos primeiros estágios de sua evolução. Assim, os que ainda propagam esta visão consideram que teria um longo periodo de graça e de existência pacifica, mas dizem que os humanos simplesmente não tinham a capacidade mental para mudar sua simplicidade por complexidade social e realização tecnológica.

Em um golpe fundamental à civilização, agora aprendemos que não só foi a vida das pessoas uma vez, e para tão muito tempo, um estado que não sabia a alienação ou a dominação, mas como as investigaçôes desde os anos 80 por arqueólogos John Fowlett, Thomas Wynn, e os outros mostraram, aqueles seres origens com uma luz nova.

\section{Sobre o CMI}

Com a finalidade de colocar a questão de nossa capacidade mental em seu contexto, é útil rever as diversas interpretações (com frequeência carregadas de num grau ligeiramente menor, Desmond Morris e Lionel Tiger. Na mesma direçâo, Sigmund Freud e Konrad Lorrenz descreveram a depravaçẫo inata da espécie, num grau ligeiramente menor, Desmond Morris e Lionel Tiger. Na mesma direção, Sigmund Freud e
contribuindo assim com uma pedra no edificio da aceitaçẫo da hierarquia e do poder no presente.

Felizmente, um panorama muito mais plausivel acabou por emergir, correspondendo a um conhecimento geral da vida paleolitica. O compartilhar e repartir os alimentos foram finalmente considerados como um aspecto importante na vida das primeiras sociedades humanas (i.e. Washburn and Devore, 1961). Jane dois milhôes de anos. Esta teoria avançada nos inícios dos anos 70 por Linton, Zihiman, Tanner e Isaac, da tese de cooperação, acabou por ser a dominante. Um dos elementos convincentes a favor da tese da cooperação, contra a da violência generalizada e da dominação dos machos, é a da diminuiçẫo, já nos primeiros estágios da evolução, da diferença de tamanho e peso entre machos e fêmeas. O dimorfismo sexual era inicialmente muito pronunciado, incluindo tais

\section{Fig. 2.14 Assunto: Política (geral)}


- Política nacional: assuntos que envolvem diretamente atuação das esferas políticas institucionais (sejam nacionais ou regionais), na maioria dos casos citadas nominalmente no texto (figuras da política, partidos, governos federal, estadual e municipal, atuação ou omissão dos mesmos, corrupção).

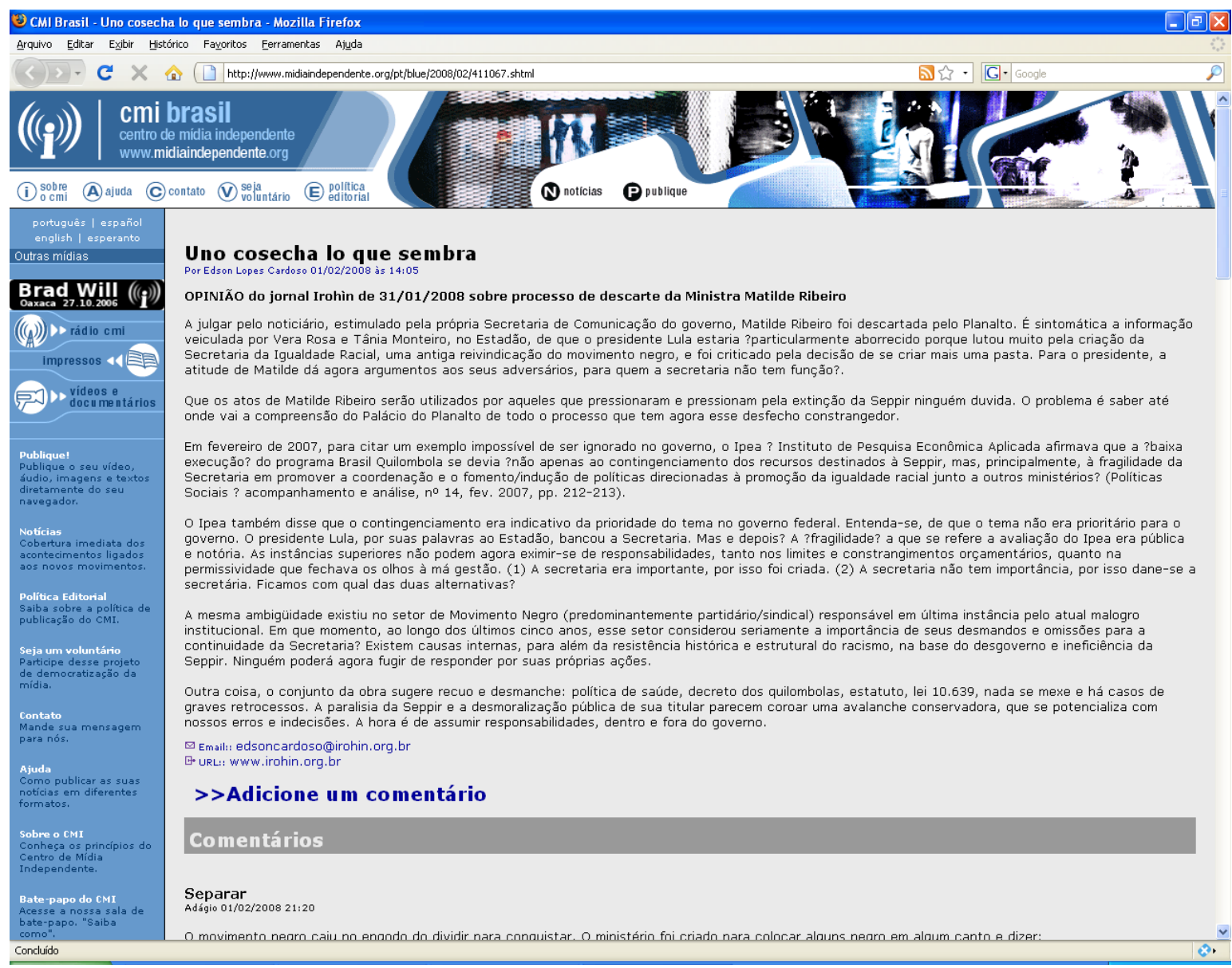

Fig. 2.15 Assunto: Política nacional 
Arquivo Editar Exibir Histórico Fayoritos Ferramentas Ailuda

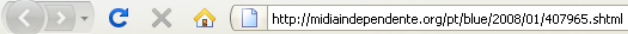

((())) $\mid \begin{aligned} & \text { cmi brasil } \\ & \text { centro de midia independente } \\ & \text { www.midiaindependente.org }\end{aligned}$

(i) 0 cobre (A) ajuda (C) contato (V) voluntário (E) politica
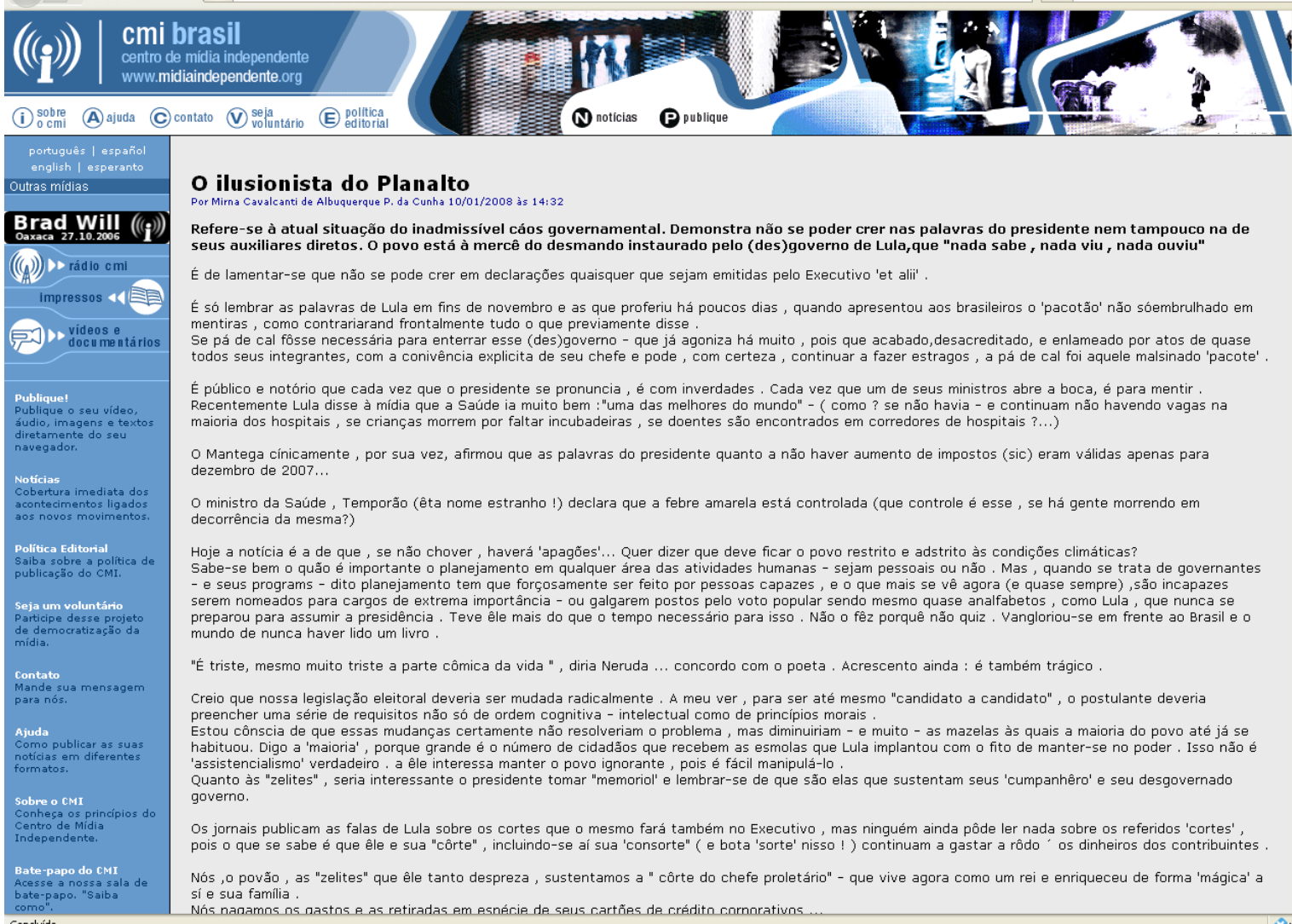

\section{O ilusionista do Planalto}

Refere-se à atual situação do inadmissivel cáos governamental. Demonstra não se poder crer nas palavras do presidente nem tampouco na de seus auxiliares diretos. O povo está à mercê do desmando instaurado pelo (des)governo de Lula, que "nada sabe, nada viu, nada ouviu"

É de lamentar-se que não se pode crer em declarações quaisquer que sejam emitidas pelo Executivo 'et alii'

É só lembrar as palavras de Lula em fins de novembro e as que proferiu há poucos dias, quando apresentou aos brasileiros o 'pacotão' não sóembrulhado em mentiras, como contrariarand frontalmente tudo o que previamente disse. Se pá de cal fôsse necessária para enterrar esse (des)governo - que já agoniza há muito, pois que acabado, desacreditado, e enlameado por atos de quase
todos seus integrantes, com a conivência explicita de seu chefe e pode, com certeza, continuar a fazer estragos, a pá de cal foi aquele malsinado 'pacote'

É público e notório que cada vez que o presidente se pronuncia, é com inverdades. Cada vez que um de seus ministros abre a boca, é para mentir , Recentemente Lula disse à mídia que a Saúde ia muito bem :"uma das melhores do mundo" - (como ? se não havia - e continuam não havendo vagas na maioria dos hospitais, se crianças morrem por faltar incubadeiras, se doentes são encontrados em corredores de hospitais ?...)

o Mantega cínicamente, por sua vez, afirmou que as palavras do presidente quanto a não haver aumento de impostos (sic) eram válidas apenas para

o ministro da Saúde, Temporão (êta nome estranho !) declara que a febre amarela está controlada (que controle é esse, se há gente morrendo em decorrência da mesma?)

Hoje a notícia é a de que , se não chover , haverá 'apagões'... Quer dizer que deve ficar o povo restrito e adstrito às condiç̃̃es climáticas?

(eje serem nomeados para cargos de extrema importância - ou galgarem postos pelo voto popular sendo mesmo quase analfabetos, como Lula, que nunca se preparou para assumir a presidência . Teve êle mais do que o tempo necessario para isso. Nẵo o fêzz porquê não quiz . Vangloriou-se em frente ao Brasil e o mundo de nunca haver lido um livro.

"É triste, mesmo muito triste a parte cômica da vida ", diria Neruda ... concordo com o poeta . Acrescento ainda : é também trágico .

Creio que nossa legislação eleitoral deveria ser mudada radicalmente . A meu ver, para ser até mesmo "candidato a candidato", o postulante deveria preencher uma série de requisitos não só de ordem cognitiva - intelectual como de princípios morais. ". Estou cônscia de que essas mudanças certamente não resolveriam o problema, mas diminuiriam - e muito - as mazelas às quais a maioria do povo até já se

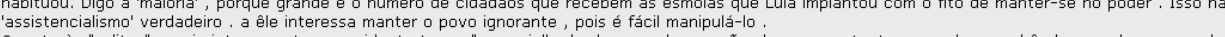
'Quanto à "zelites", seria interessante o presidente topor "memoriol" e lembrar-se de que sẫo

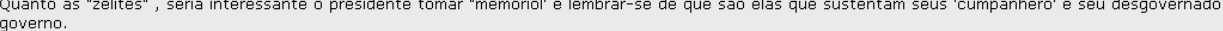
Os jornais publicam as falas de Lula sobre os cortes que o mesmo fará também no Executivo, mas ninguém ainda pôde ler nada sobre os referidos 'cortes', pois o que se sabe é que êle e sua "côrte", incluindo-se ai sua 'consorte" (e bota 'sorte' nisso !) continuam a gastar a rôdo " os dinheiros dos contribuintes Nós ,o povão, as "zelites" que êle tanto despreza, sustentamos a " côrte do chefe proletário" - que vive agora como um rei e enriqueceu de forma 'mágica' a Nós nanamns ns nastns e as retiradas em esnécie de seus cartões de créditn cornorativns

Fig. 2.16 Assunto: Política nacional 
- Política - internacional: postagens que tratam de temas políticos específicos de determinada região do mundo que não o Brasil, e que envolvem atuação das esferas políticas institucionais. Por notar a recorrência de determinadas regiões, dividimos esta categoria em: Política - internacional (América Latina); Política - internacional (EUA); Política - internacional (Oriente Médio); Política - internacional (Europa).

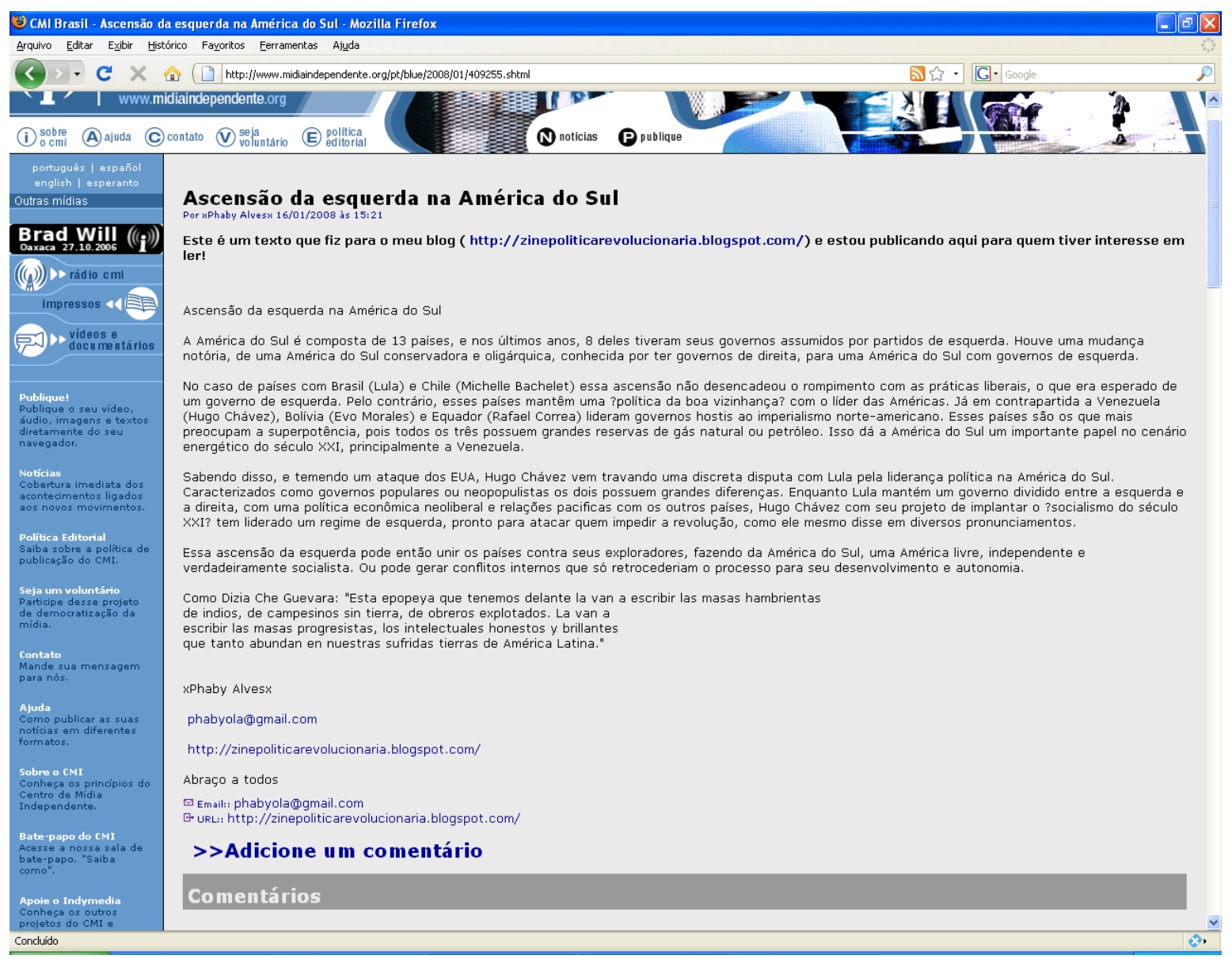

Fig. 2.17 Assunto: Política - internacional (América Latina) 


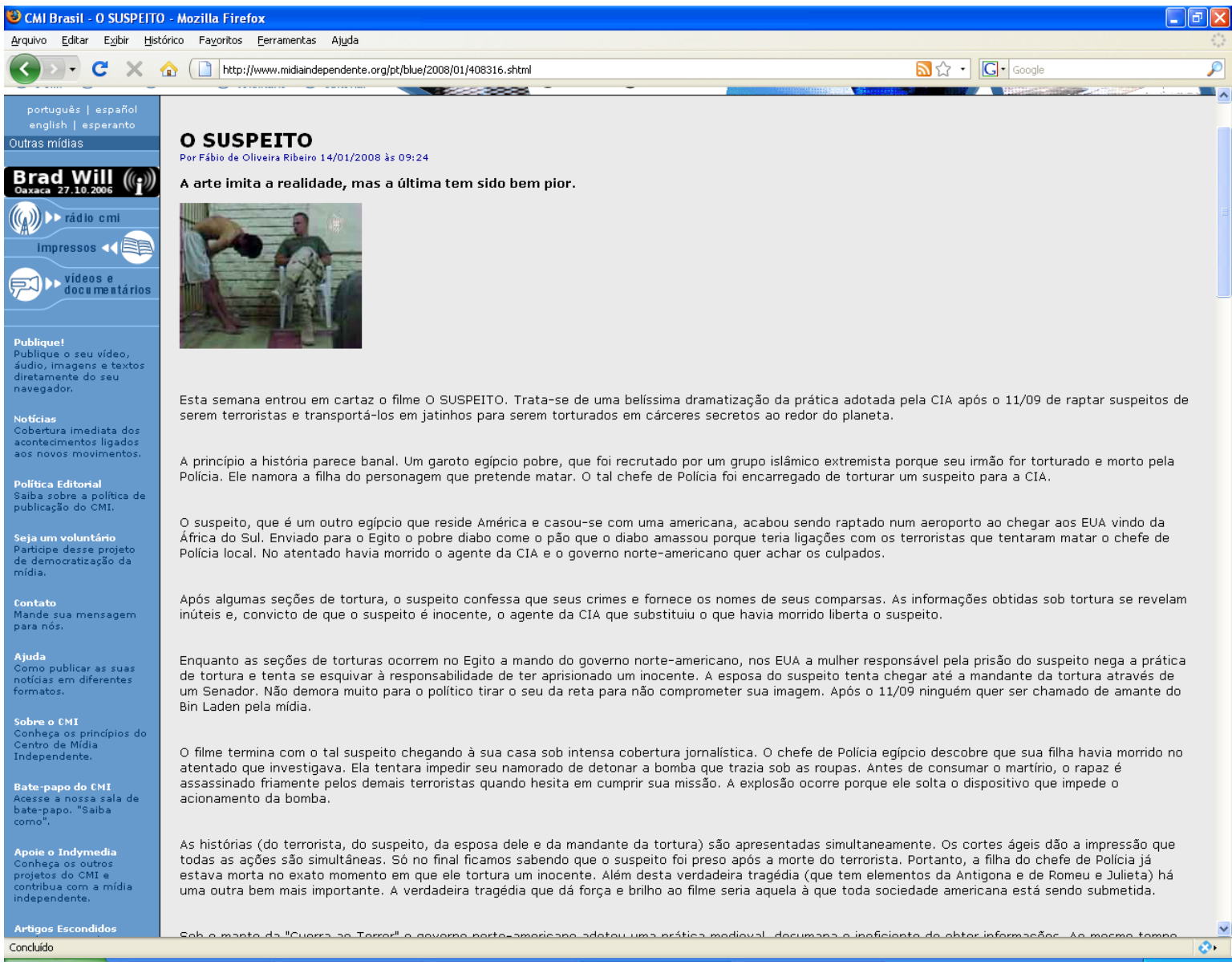

Fig. 2.18 Assunto: Política - internacional (EUA) 


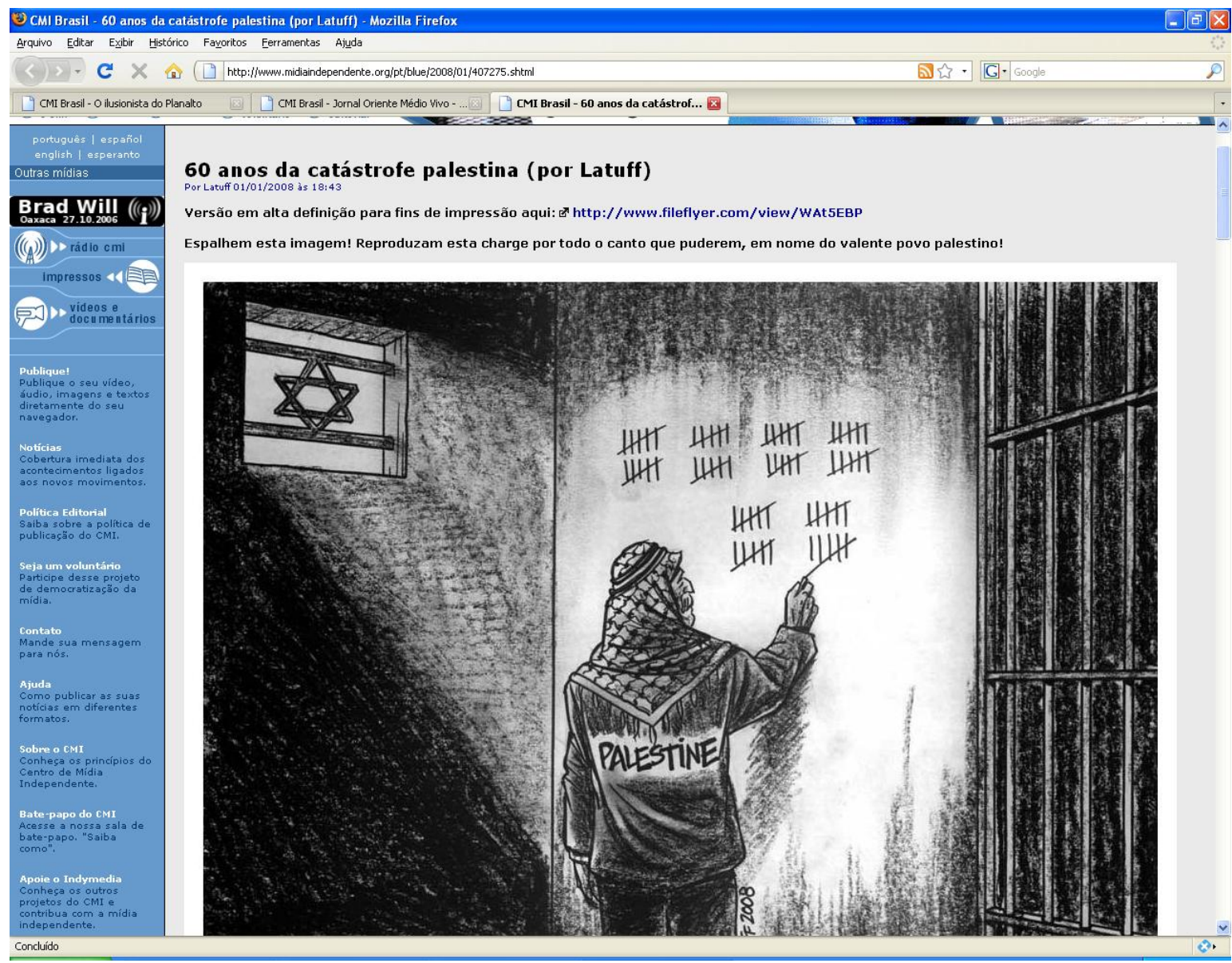

Fig. 2.19 Assunto: Política - internacional (Oriente Médio) 


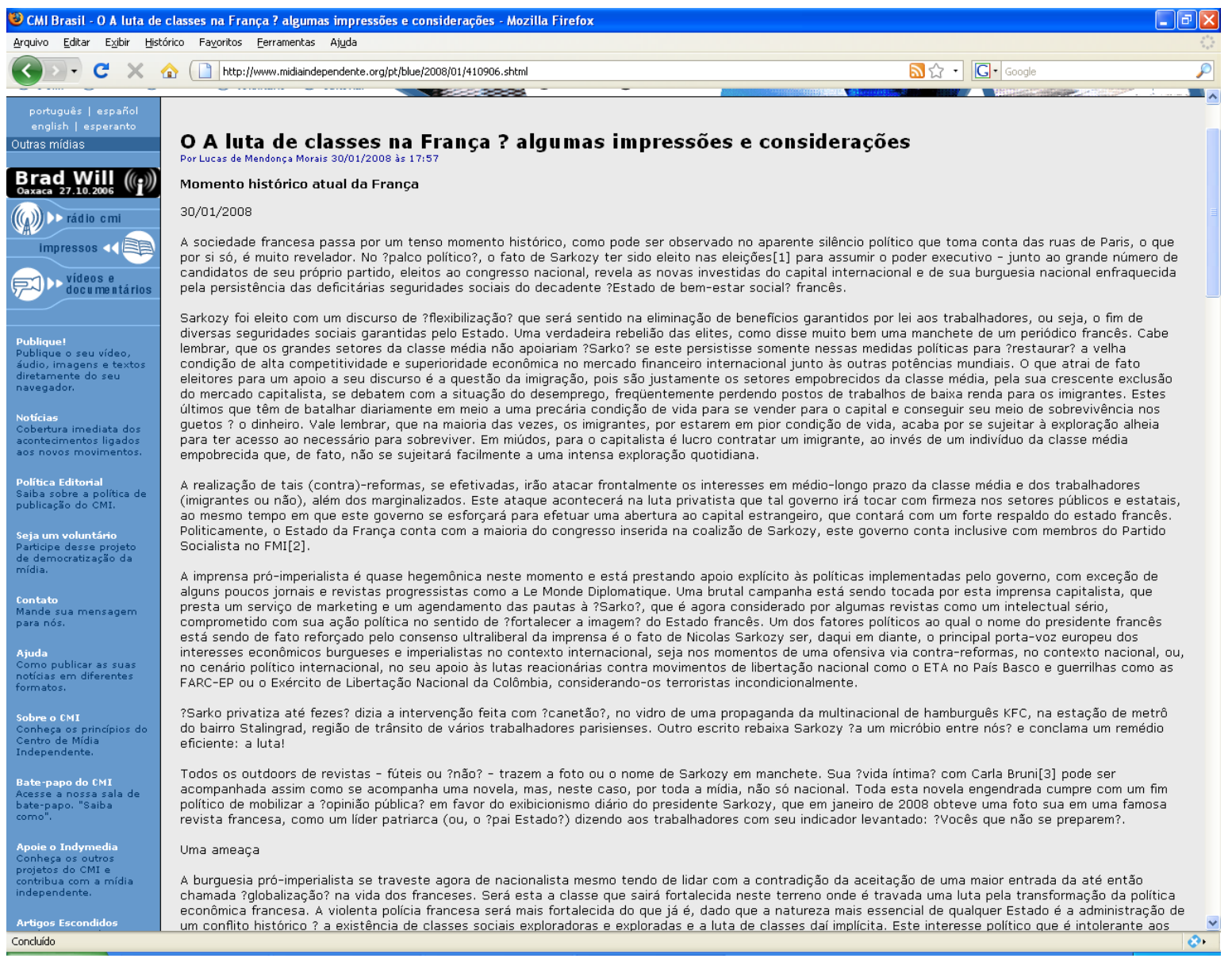

Fig. 2.20 Assunto: Política - internacional (Europa) 
- Mídia: análises e críticas de veículos de mídia específicos ou dos meios de comunicação comerciais como um todo. Divulgação de iniciativas de mídia alternativa e/ou comunitária, como por exemplo, as rádios livres.

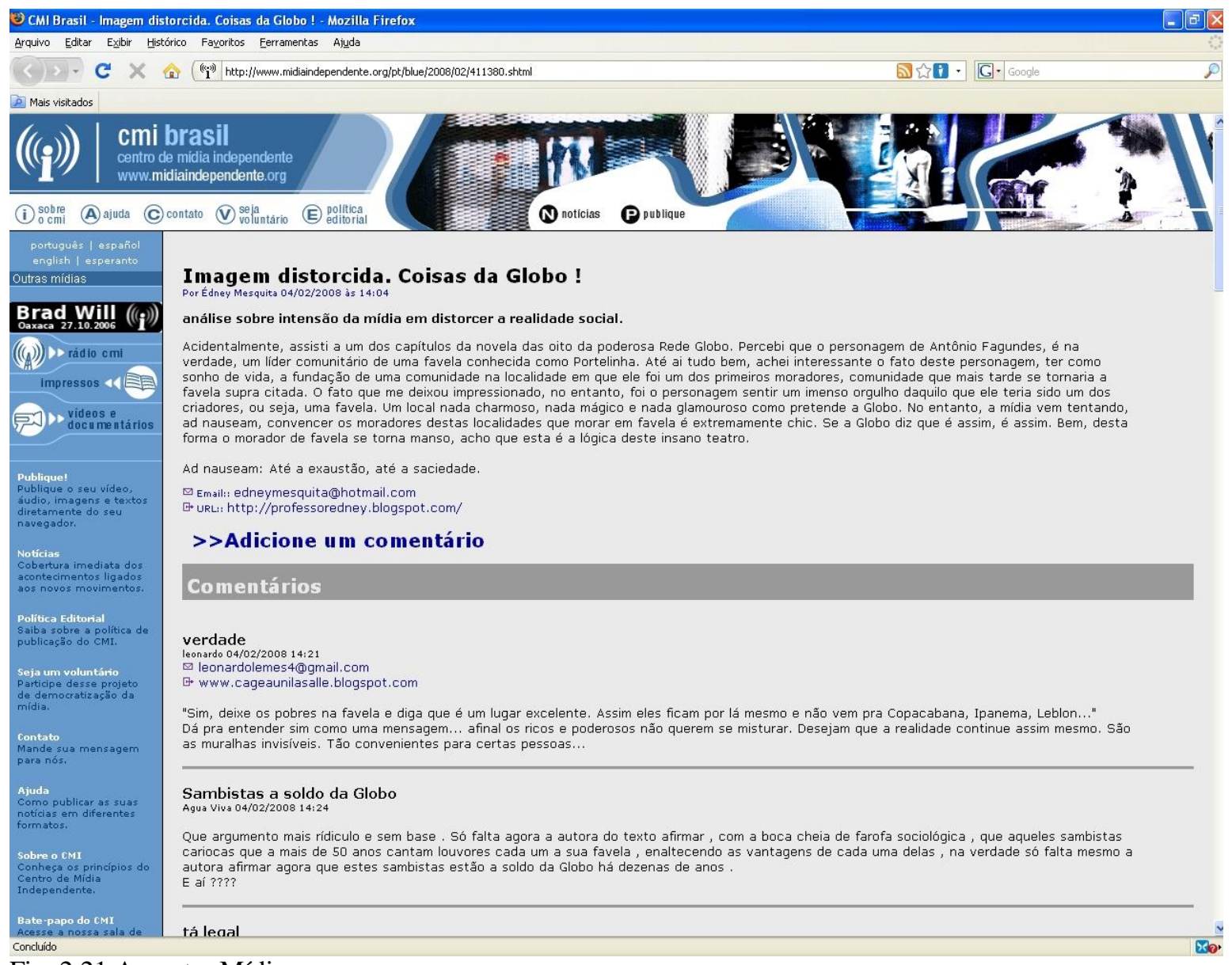

Fig. 2.21 Assunto: Mídia 


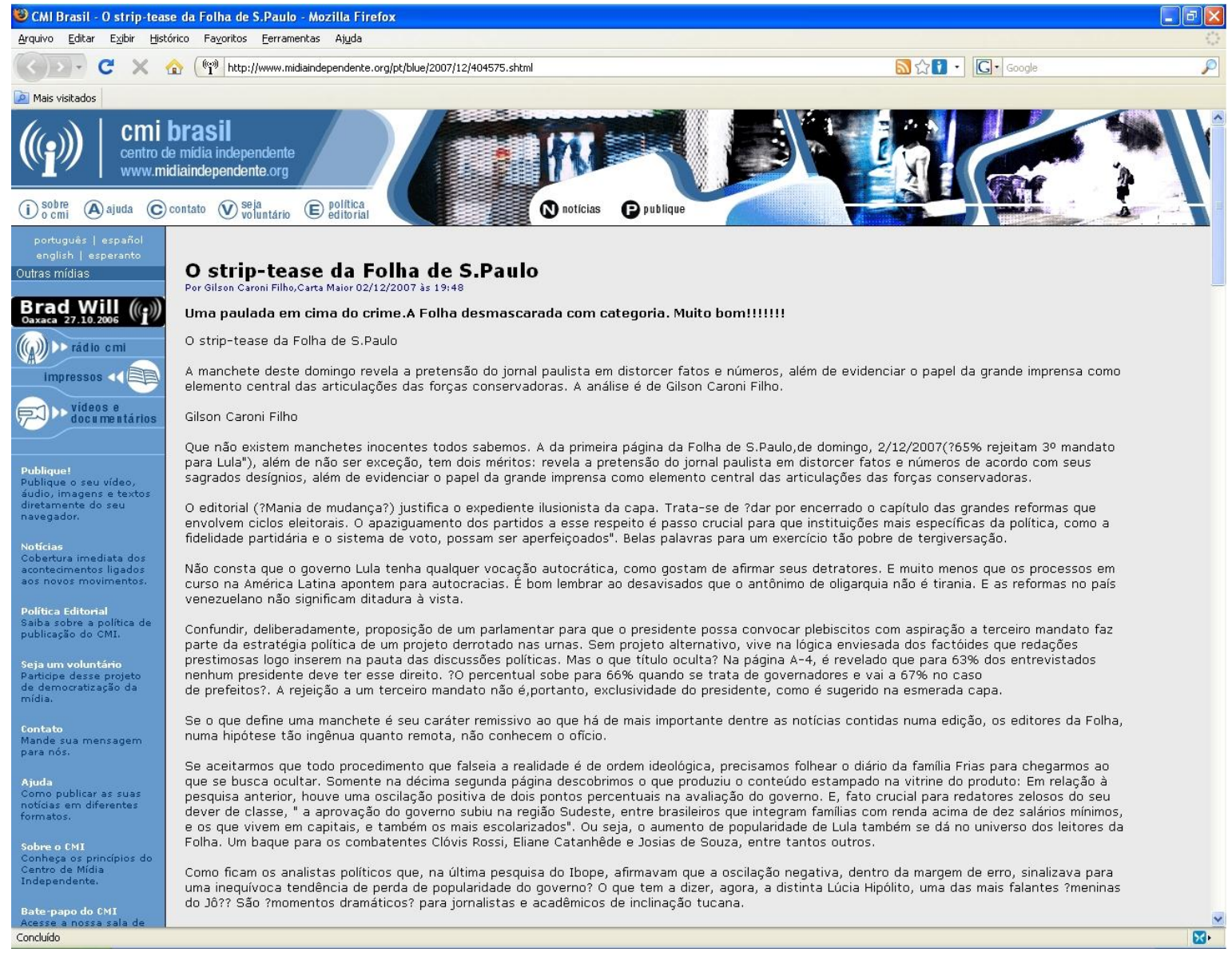

Fig. 2.22 Assunto: Mídia 
- Movimento estudantil: postagem em que as questões do movimento estudantil sejam o foco principal.

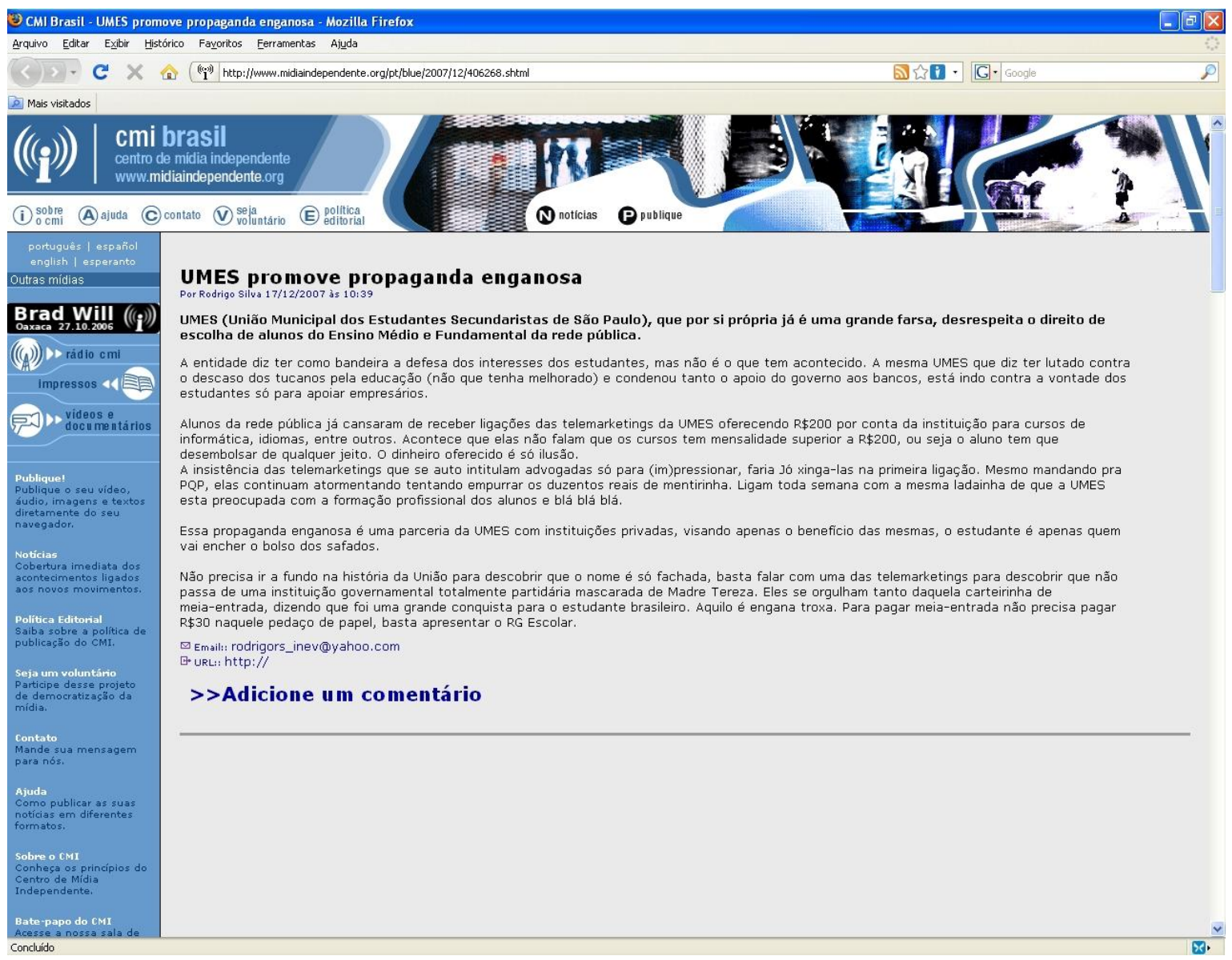

Fig. 2.23 Assunto: Movimento estudantil 
Arquivo Éditar Exibir Histórico Fayoritos Eerran

\$ڤ? G. Google

20. Mais visitados

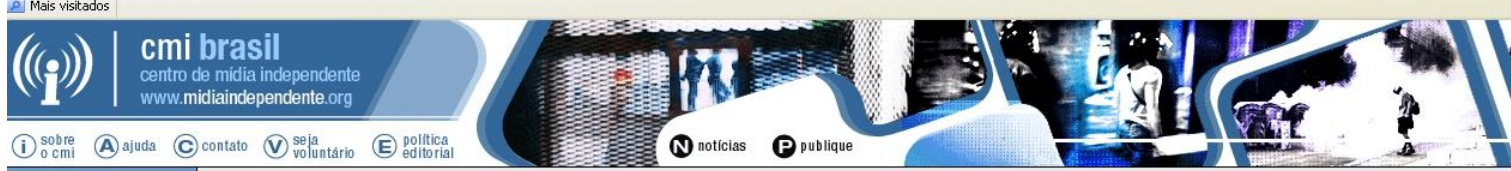

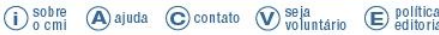

O Estudante projeta o que vive, Ele é um ser social

$\underset{\text { Baxaca 27.10.2006 }}{\operatorname{Brad}}((-p))$

((Q)) $)$ P rádio cmi impressos 4 每目

国 $\longmapsto \begin{aligned} & \text { videos e } \\ & \text { documentários }\end{aligned}$
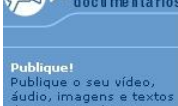

Sudio, imagens a te
diretamente do seu

diretamente
navegador.

Noticias
Cobertura imediata dos
Contecimentos ligados

aconterimentos ligados
aos novos movimentos.

Politica Editori

Saiba sobre a politica de
publicaşo do CMI.

Seja um voluntánio

Sarticipe desse projeto
de democratizasăo da

Contato
Mande sua mensagem
para nós.

para nós.

Ajuda
Como publicar as suas
oticias em diferentes

ooticias em dif
colmatos.
Sobre o CMI

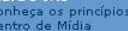

Centro de Midia
Independente.

Bate- papo do CMI
Acesse a nossa sal

Bate-papo
Acesse a no
Concluído

Dá para captar os fundamentos teóricos positivos de uma realidade que teima em ser, paradoxa, cruel e desumana. Pare e recomece.

Qual a motivaçã̃o para o estudante brasileiro ? todo dia ele consome a bomba da

realidade desumana e cruel em que vive, Estado inpeto, corrupção escancarada,

politicos corruptos impunes, violencia nos presidios, os fortes matando e

chateação e da cobrança. - O Que foi que tu ganhaste com esta tua honestidade ?

- Esta honestidade serve para que mesmo? Enfim, estamos vivendo um época da

inversão de valores. Neste terreno fácil, do mundo fácil, pela queima de etapas

o palhaço, o clandestino da malversaçãa ridicula de uma politica que beneficia

honestos, os cidadãos, os baranabés, os homens de bem, é uma polica muito

interessante, contanto que não se espere muito da aprimoração intelectual da

socidade, principalmente, da classe estudantil. Primeiro: o estudante está se

um doutor para viver no meio dos oportunistas? Vale a Pena ser um construtor

social no meio dos espertalhões? Vale a pena ser um barnabe para ser vaiado

pelos gaiatos de um Capitalismo selvagem que somente benencia os que so serven

para ser garotos ou garotas de marketing de um capitalismo excludente e que

greve é logo taxado de oportunista, idiota. O Que esperar da classe estudanti

quando "os sem diplomas" são os grandes diplomados na arte de concentrar

capitais, poder, prestígio, dinheiro e lucro fácil. Os Estudantes devem

realmente passar por um crise ou "uma bomba de realidade táo forte", tão intensa,

que estudar ja não é táo importante pelo menos no momento atual. Mas a qualquer

sim, deveremos investir no "ser", através do estudo da prática do bem comum, da

ética, do respeito, do compromisso com a socieade, com o Estado, com a familia.

Afinal "o ter" passa, porém, -o SER é Eterno.

घmaili: deuteronomioarte@bol.com.br

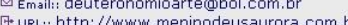

> >Adicione um comentário

Fig. 2.24 Assunto: Movimento estudantil 
- Movimento sindical: postagem em que as questões do movimento sindical sejam o foco principal.

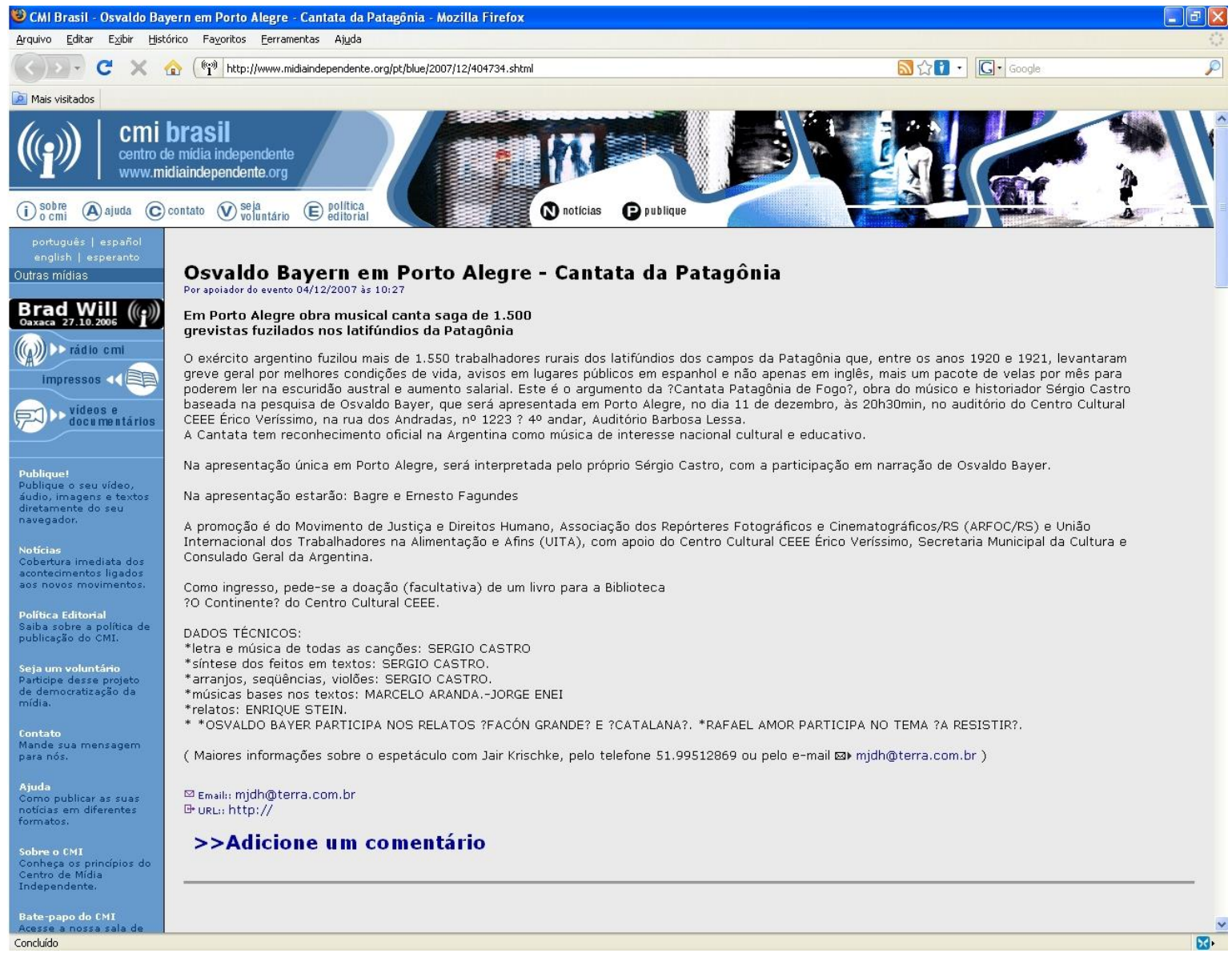

Fig. 2.25 Assunto: Movimento sindical 
20) Mais vistados

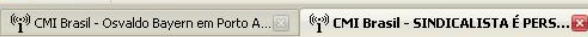

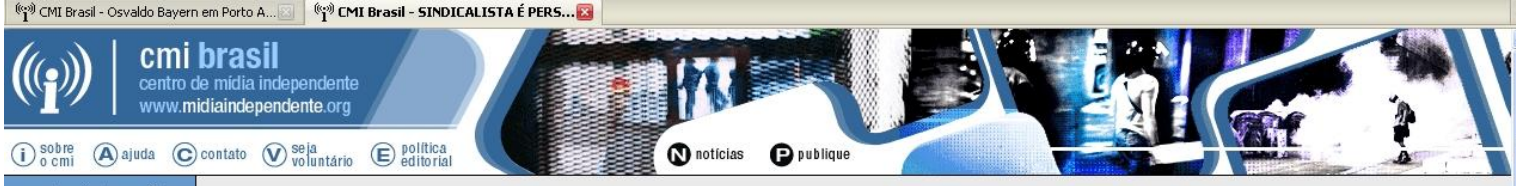

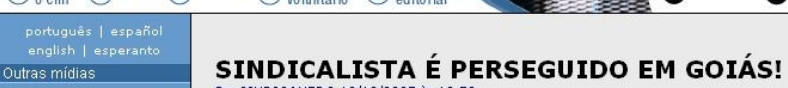

\section{Brad Wiill $(((p)))$}

$(($ (p)) $)$ Pr radio cmi Impressos 4 具
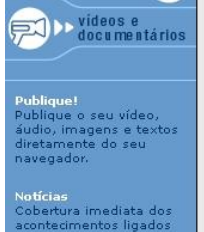

aos novos movim
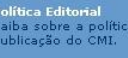

Seja um voluntário
Participe desse projeto

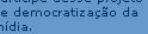

contato

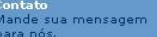

Ajuda

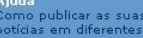

formatos.

Sonhesa o chi

Conhesa os prin
centrod de Midia
Independente.

Concluido o diretor juridico do Sindicato dos Trabalhadores Municipais de Senador Canedo - Go está sofrendo fortes retaliaçóes por organizar a luta classista dos trabalhadore

A Prefeitura de Senador Canedo têm perseguido um membro do Sindicato dos Trabalhadores Municipais de Senador Canedo ? Go (SINDICANEDO) na e paralisar aqueles que estão dispostos a lutar pelos direitos do povo. A vítima da perseguição é o nosso diretor jurídico Marcelo Antônio de Bastos.

Sindicanedo e a Liga Operária vêm batendo de forma firme na prefeitura, que tem como atual prefeito o empresário Vanderlan Vieira Cardoso, um dos maiores industriais do país no ramo alimentício, que procura desenvolver um brutal sistema de exploração dos trabalhadores da prefeitura e de suas empresas.

To têm um grande histórico de lutas em defesa dos interesses dos trabalhadores locais, sendo um dos mais ativos organizadores trabalho (todas sem justificativas!). Depois de participar de uma reuniẫo com a Secretaria de Educação para cobrar melhorias do sucateado transporte escolar, foi transferido para o caminhão de lixo de forma arbitrária e antidemocrática.

thistorico de perseguição e o seguinte: o companheiro Marcelo trabahou por quatro anos na ambulância. Iniciaram a perseguição através da transferência para todas as ambulancias. Logo apos foi posto em disposição durante dois meses. Foi transferido para a lluminaçăo, onde trabalhou Cemitério durante uma semana. Trabalhou na caminhonete A-10 do Seinfra e foi transferido novamente, para trabalhar um dia no Caminhão caçamba. Foi encaminhado para trabalhar no Caminhão Pipa. Foi lotado na Secretaria de Educação, onde trabalhou um mês e de lá foi transferido para o Transporte da Educação, trabalhando o mesmo tempo. De lá foi transferido para a coleta de lixo e agora está no banco.

O banco e uma punição imposta para os motoristas municipals que não rezam na cartilha da prefeitura. Esses trabalhadores são impedidos de dirigir os que passou a agitar, panfletar e organizar os trabalhadores com maior intensidade. Na tentativa de cala-lo, o transferiram novamente, porém, para, um banco separado dos demais trabalhadores. Não aceitando essa imposição o companheiro voltou para 0 antigo banco e voltou a denunciar as artimanhas da prefeitura.

Para piorar a situação, o companheiro Marcelo foi intimado pelo Sr. Ronan (chefe da Secretaria de Infra-Estrutura - SEINFRA) para receber uma advertência no dia 04/12/07, alegando que esse ?náo estava sentado no banco certo?, sendo que o funcionário se encontrava no local de trabalho.

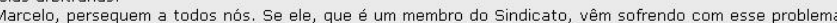
podemos nos indignar com a repressão contra os trabalhadores no dia a dia de trabalho. Esses ataques são formas de tentar nos intimidar, nos fazer recuar da posição de luta, o que jamais permitiremos que aconteça.

(ascismo que se alastra pelo pais, onde as classes exploradoras ampliam a repressão estão à lei contra as greves em curso no congresso nacional, que é produzida com aval do governo federal e do Ministério do Trabalho. Essas açốes são tentativas de conter a rebelião das massas exploradas, já que a situação revolucionária se desenvolve por todo o país, com combativas greves e grandes ocupações de terras. Convidamos todos os democratas a lutar contra mais esse abuso. Por esse motivo pedimos que todos enviem e-mails para o Ministério do Trabalho e
para a prefeitura de Senador Canedo, pedindo que cesse a perseguição e que retorne o companheiro Marcelo para a Secretaria que estava lotado. Os

Fig. 2.26 Assunto: Movimento sindical 
- Conteúdo sem relação com a política editorial: postagens que, apesar terem assunto fora do escopo definido na política editorial, tenham permanecido fora da seção

“Artigos escondidos".

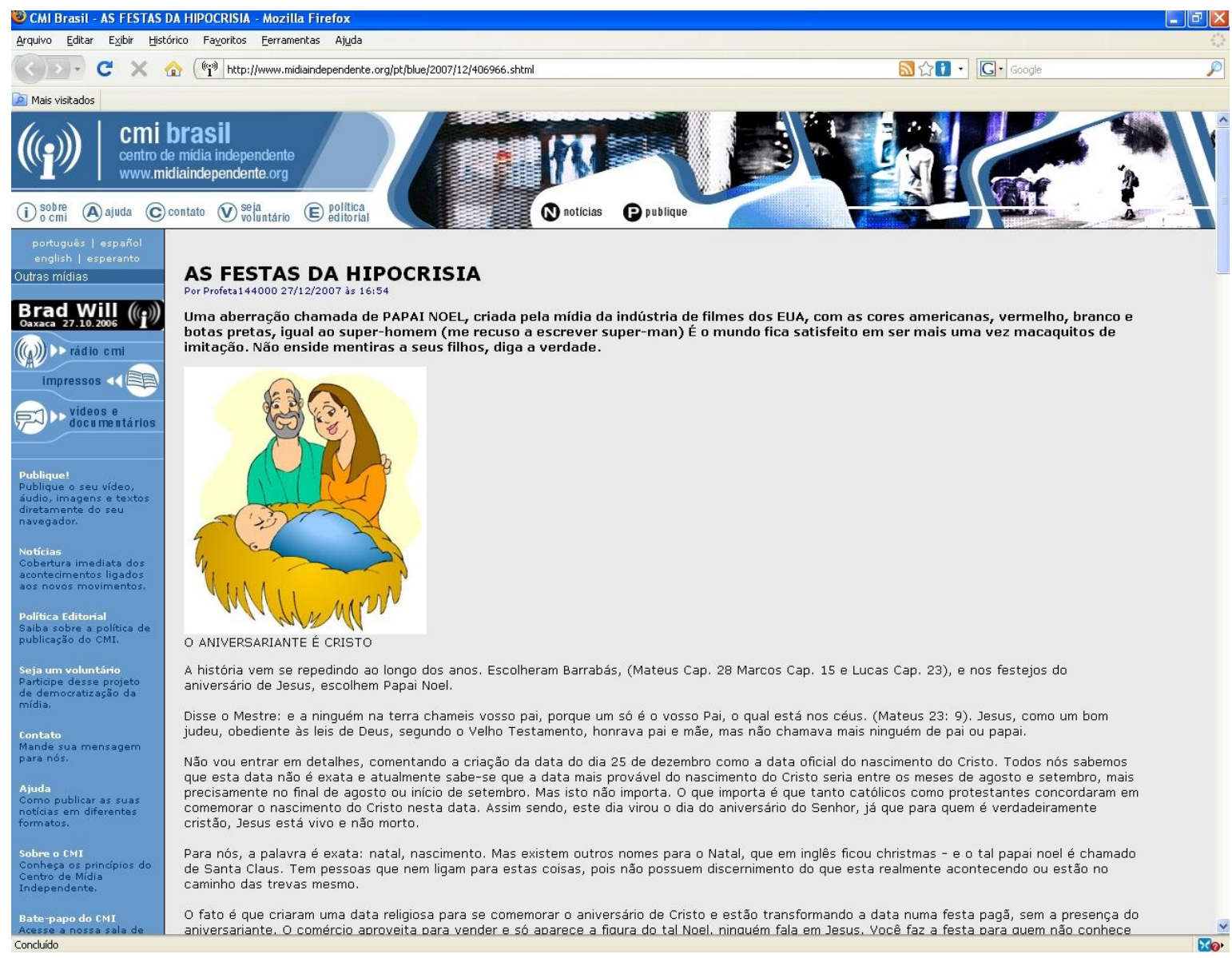

Fig. 2.27 Assunto: Conteúdo sem relação com a política editorial 
Arquivo Editar Exibir Histórico Fayoritos Ferramentas Aild

[0] Mais visitados

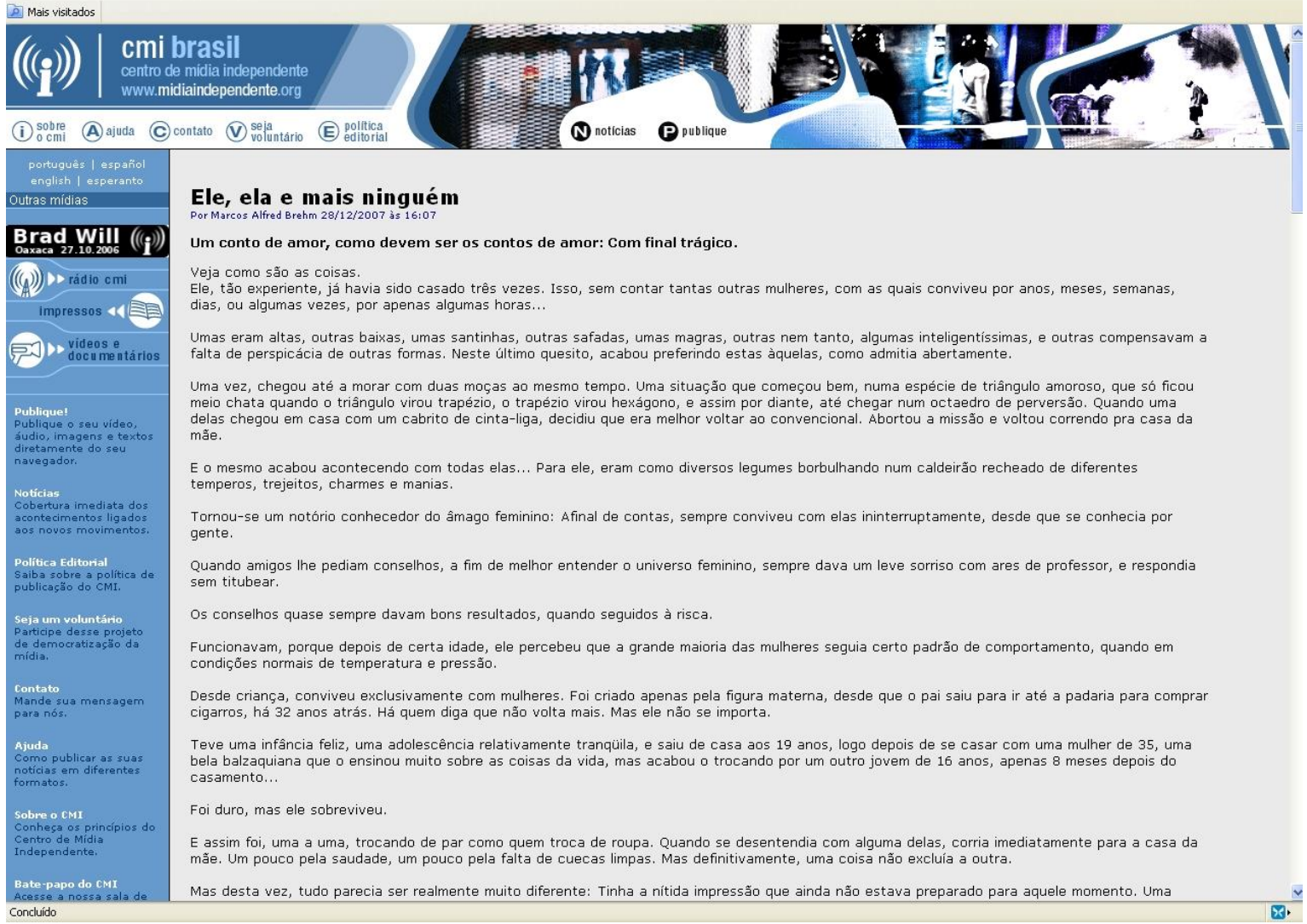

Fig. 2.28 Assunto: Conteúdo sem relação com a política editorial 


\section{Sobre a categoria "Tipo de postagem"}

Apesar da grande variedade de formatos de texto, pudemos observar grupos de postagens com características comuns neste quesito, categorias que organizamos como a seguir.

- Notícia de movimento/organização: texto ou imagem com texto com característica de atualidade (relato de fatos recentes ou anúncio de eventos programados) redigido por representante ou em prol da causa de algum movimento, organização social ou coletivo de ativistas específico, mencionado na postagem.

- Notícia opinativa: texto ou imagem com texto com característica de atualidade (relato de fatos recentes ou anúncio de eventos programados) e comentário explicitamente opinativo sobre os fatos relatados. Uso numeroso de adjetivos, juízos explícitos, tomada de partidos. Destacamos aqui o fato de serem explícitos, por ser ponto quase pacífico entre os teóricos atuais do jornalismo que não há notícia que não leve algum grau de subjetividade e opinião, porém, em geral transmitida de forma indireta, nem sempre consciente, pela abordagem do fato e pelo foco que se escolhe dar a ele.

Como sugere Bucci:

A objetividade no jornalismo, que é intersubjetividade, não pede isenção total pede equilíbrio. Nas duas hipóteses (excesso de frieza ou excesso de emocionalismo), pode-se atribuir um déficit de qualidade à má adequação entre as convicções do repórter e sua tarefa de obedecer um relato eficiente dos acontecimentos: ou ele encenou neutralidade e frustra seu público, ou produziu uma narrativa panfletária, e confunde o público. Por uma e por outra desinforma. (Bucci, 2000, p.95).

No caso desta categoria, a opinião é dada de forma direta, algumas vezes até assumida como tal, com uso, por exemplo, da primeira pessoa (ponto de vista), alternando-se com a terceira (quando vai se falar do fato em si).

- Notícia: texto ou imagem com texto com característica de atualidade (relato de fatos recentes ou anúncio de eventos programados) e que não seja redigido por representante ou em prol da causa de algum movimento, organização social ou 
coletivo de ativistas específico, mencionado na postagem - e também que não tenha as características opinativas explícitas que descrevemos no formato Notícia opinativa.

- Texto opinativo: texto ou imagem com texto sem característica de atualidade que permita defini-lo como "notícia" e que explicite opiniões diretas sobre o tema discutido.

- Texto de movimento/organização: texto ou imagem com texto sem característica de atualidade que permita defini-lo como "notícia", e redigido por representante ou em prol da causa de algum movimento, organização social ou coletivo de ativistas específico, mencionado na postagem.

- Charge: texto imagético com teor de sátira ou crítica (fotomontagens, desenhos, tiras, caricaturas, cartoons).

- Outros: poesia, texto científico, letra de música, entrevista, texto acadêmico entre outros que não se incluem especificamente nos formatos acima. Por não haver um número expressivo de cada tipo, e para fins de contagem, optamos por colocá-los em uma mesma categoria à parte.

\section{Questionário}

Enviamos, por email, um questionário para os autores das postagens que registramos durante estes 90 dias. A intenção foi a de aferir dados básicos sobre os usuários da coluna da direita, por meio de questões objetivas (seleção de alternativas) que atendessem ao propósito de traçar suas características gerais. Procuramos não estender demais o número de questões e alternativas para não desestimular a participação. Em apenas uma das questões, que demandava este tipo de abertura, constou uma alternativa "Outra", com espaço para nomeação pelo próprio respondente. Referimo-nos à questão sobre qual era sua "orientação política", de certa maneira controversa, e de difícil delimitação - como, por exemplo, definir-se "de esquerda", seja liberal ou autoritária, atualmente ${ }^{20}$ - mas que mesmo com esta

\footnotetext{
${ }^{20}$ Concordamos com Azzi (2007, p.96), que, recorre a Bobbio para avaliar que "As noções de esquerda e direita, sobretudo hoje em dia, estão bastante opacas e indistintas, mas o referencial amplo aqui utilizado tem sido o de que '(...) o que caracteriza a esquerda perante a direita é o ideal, inspiração ou a
} 
ressalva optamos por inserir no questionário, julgando que seria interessante ouvir o que os participantes diriam a respeito.

A última questão foi a única inteiramente aberta, onde pedimos para o participante deixar um comentário geral ou opinião sobre o CMI. Uma pergunta um tanto quanto vaga, mas que, por isso mesmo, esperou proporcionar uma brecha para a livre manifestação dos participantes da pesquisa, que poderiam contemplar voluntariamente alguns pontos que não incluímos na mesma.

É preciso observar que, por motivos óbvios, os resultados traçam um perfil aproximado somente do público que posta e registra um email de contato. Não há como pesquisar o público que posta sem deixar dado de contato e, embora acreditemos que seja o caso, não se pode afirmar categoricamente que ambos guardem as mesmas características.

Abaixo, o questionário enviado.

Olá,

Meu nome é Luiza Caires, e faço uma pesquisa de mestrado para a USP sobre o perfil do público que utiliza o www.midiaindependente.org.

Você postou conteúdo no site do CMI e deixou seu email, por isto te convido a participar.

\section{NÃO É NECESSÁRIO SE IDENTIFICAR.}

Basta responder às 10 questões abaixo e enviar a resposta para este email.

Muito obrigada.

Faça um $\mathrm{X}$ ao lado da alternativa escolhida:

1) Sexo:

a) Feminino

b) Masculino

2) Idade:

a) Menos de 18 anos

b) Entre 18 e 25 anos

paixão que costumamos chamar de "ethos da igualdade"' (Bobbio, 2001, pp. 150-152, 156). Se for correto situar o movimento antiglobalização num espectro político ao qual geralmente damos o nome amplo de esquerda, então é preciso situar também qual é a ampla direita em relação à qual se situa. (...) [P]ara efeito de análise desses movimentos a direita contemporânea deve ser compreendida como aquelas forças políticas que, nos campos econômico, político e cultural, operam a favor da liberdade do capital e contra as formas dissensuais da política atual, o que não é compatível com qualquer 'ethos da igualdade". 
c) Entre 25 e 35 anos

d) Mais de 35 anos

3) Região do País onde mora:

a) Sudeste

b) Nordeste

c) Centro-oeste

d) Norte

e) Sul

4) Nível educacional mais alto que possui:

a) Ensino Básico incompleto

b) Ensino Básico completo

c) Ensino Médio incompleto

d) Ensino Médio completo

e) Ensino Superior (completo ou incompleto)

5) Há quanto tempo acessa o CMI:

a) 1 ano ou menos de 1 ano

b) Mais de 1 ano e menos de 2 anos

c) Mais de 2 anos e menos de 3 anos

d) Mais de 3 anos

6) Orientação política:

a) Anarquista

b) Esquerda liberal

c) Esquerda autoritária

d) Direita liberal

e) Direita autoritária

f) Outra

7) Pertence a alguma organização ou movimento social?

a) $\mathrm{Sim}$

b) Não

8) Escreve em um blog ou algum outro site?

a) $\mathrm{Sim}$

b) Não

9) Qual tipo de conteúdo você posta ou postava com mais frequência no CMI?

a) Notícia redigida por você

b) Notícia redigida por outra pessoa

c) Texto opinativo redigido por você

d) Texto opinativo redigido por outra pessoa

e) Foto ou charge

f) Vídeo ou áudio

10) Você participa ou já participou de algum coletivo regional/nacional do CMI (lista de emails e/ou reuniões presenciais)?

a) $\mathrm{Sim}$

b) Não

* Deixe sua opinião ou um comentário sobre o site do CMI: 


\subsubsection{Resultados - pesquisa com usuários da coluna da direita}

\section{Assuntos da postagem}

Entre um total de 487 postagens classificadas, tivemos o seguinte resultado:

\begin{tabular}{|c|c|c|}
\hline Assunto & Número de postagens & Porcentagem \\
\hline Problemas sociais & 115 & $24 \%$ \\
\hline Política nacional & 67 & $14 \%$ \\
\hline Política (geral) & 57 & $12 \%$ \\
\hline Conteúdo sem relação com a política editorial & 57 & $12 \%$ \\
\hline Política internacional & 54 & $11 \%$ \\
\hline Política internacional (América Latina) & 29 & \\
\hline Política internacional (Oriente Médio) & 7 & \\
\hline Política internacional (EUA) & 13 & \\
\hline Política internacional (Europa) & 5 & \\
\hline Direitos de minorias étnicas & 32 & $6 \%$ \\
\hline Problemas ambientais & 30 & $6 \%$ \\
\hline Direitos de minorias sexuais & 21 & $4 \%$ \\
\hline Mídia & 20 & $4 \%$ \\
\hline Movimento estudantil & 18 & $4 \%$ \\
\hline Movimento pela libertação animal & 9 & $2 \%$ \\
\hline Movimento sindical & 7 & $1 \%$ \\
\hline Total & 487 & $100 \%$ \\
\hline
\end{tabular}

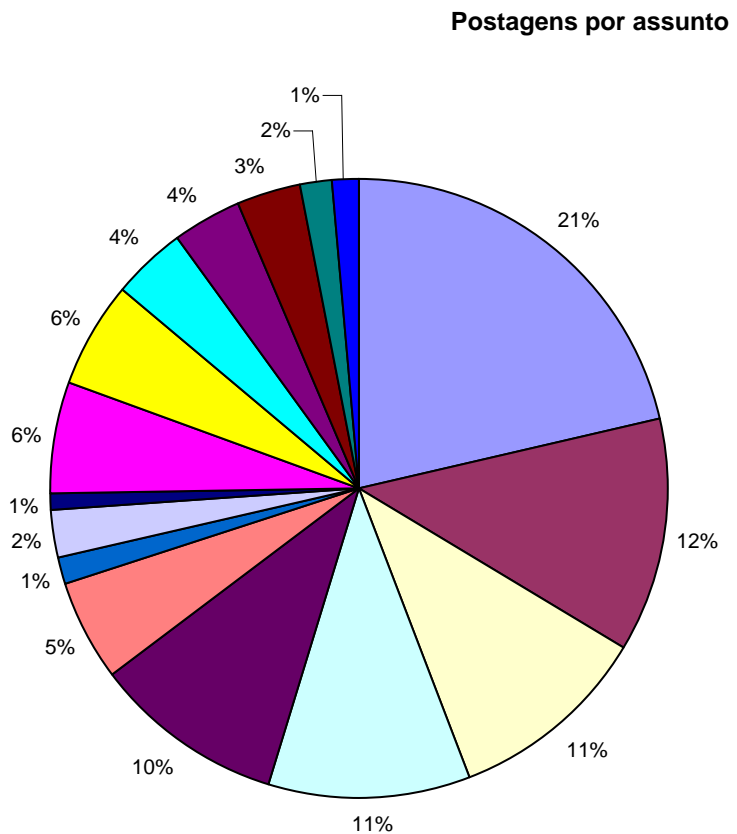

$\square$ Problemas sociais

$\square$ Política nacional

$\square$ Política (geral)

$\square$ Conteúdo sem relação com a política editorial

$\square$ Política internacional

$\square$ Política internacional (América Latina)

口Política internacional (Oriente Médio)

$\square$ Política internacional (EUA)

- Política internacional (Europa)

$\square$ Direitos de minorias étnicas

$\square$ Problemas ambientais

$\square$ Direitos de minorias sexuais

$\square$ Mídia

- Movimento estudantil

Movimento pela libertação animal

- Movimento sindical

Fig. 2.29 Gráfico de postagens por assunto 


\section{Formato da postagem}

Entre um total de 487 postagens classificadas, tivemos o seguinte resultado:

\begin{tabular}{|l|r|}
\hline Formato & Número de postagens \\
\hline Texto opinativo & 225 \\
Notícia de movimento ou organização & 122 \\
Notícia opinativa & 55 \\
Notícia & 35 \\
Texto de movimento/organização & 24 \\
Texto sem classificação & 14 \\
Charge & 12 \\
\hline Total & 487 \\
\hline
\end{tabular}

Postagens por formato

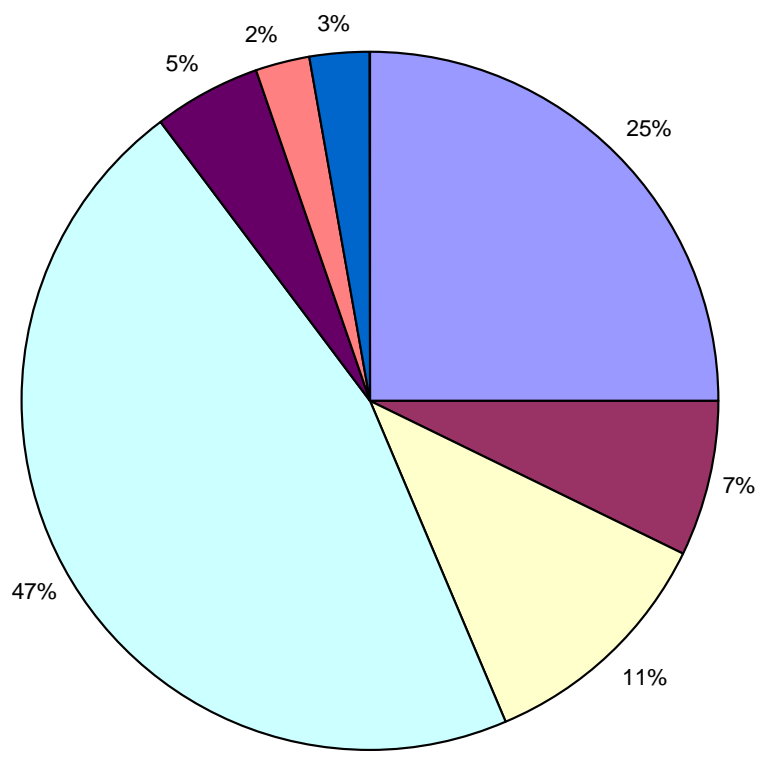

Notícia de movimento ou organização $\square$ Notícia

$\square$ Notícia opinativa

$\square$ Texto opinativo

$\square$ Texto de movimento/organização

$\square$ Charge

$\square$ Texto sem classificação

Fig. 2.30 Gráfico de postagens por formato 


\section{Respostas ao questionário}

Respostas em número e porcentagem em relação ao total de questionários respondidos (56).

\begin{tabular}{|l|r|}
\hline 1) Sexo & \\
\hline Masculino & 44 \\
Feminino & 11 \\
Sem resposta & 1 \\
\hline Total & 56 \\
\hline
\end{tabular}

Sexo

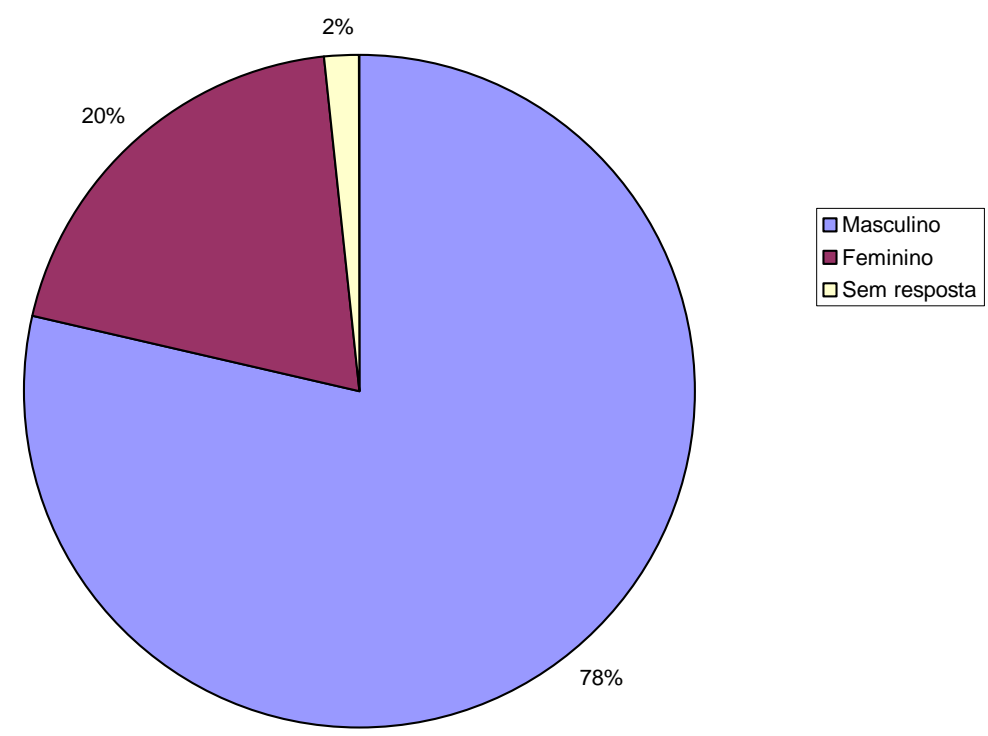

Fig. 2.31 Gráfico de usuários por sexo 


\begin{tabular}{|lr|}
\hline 2) Idade \\
\hline Mais de 35 anos & 24 \\
Entre 18 e 25 anos & 16 \\
Entre 25 e 35 anos & 15 \\
Sem resposta & 1 \\
Menos de 18 anos & 0 \\
\hline Total & 56 \\
\hline
\end{tabular}

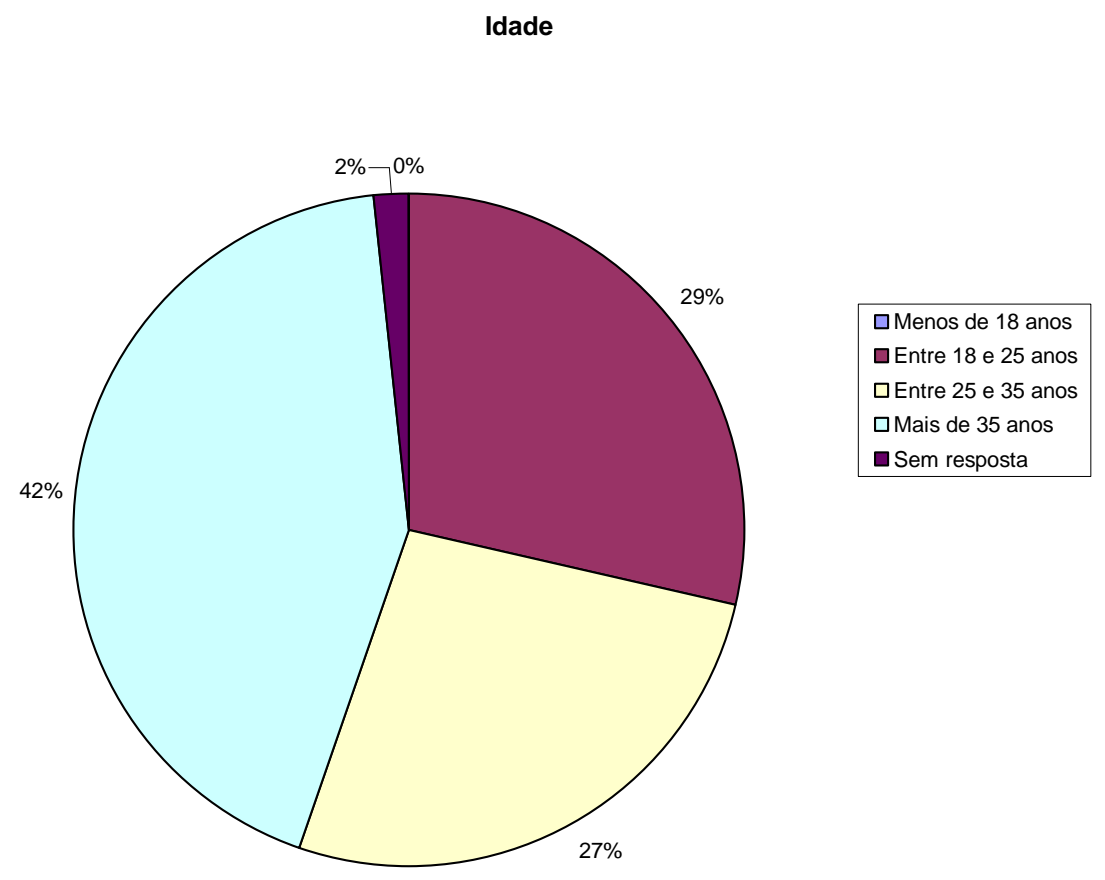

Fig. 2.32 Gráfico de usuários por idade 


\begin{tabular}{|c|c|}
\hline \multicolumn{2}{|c|}{ 3) Região onde mora } \\
\hline SE & 28 \\
\hline $\mathrm{NE}$ & 10 \\
\hline$S$ & 7 \\
\hline $\mathrm{CO}$ & 7 \\
\hline $\mathrm{N}$ & 2 \\
\hline Sem resposta & 1 \\
\hline Total & 56 \\
\hline
\end{tabular}

Região

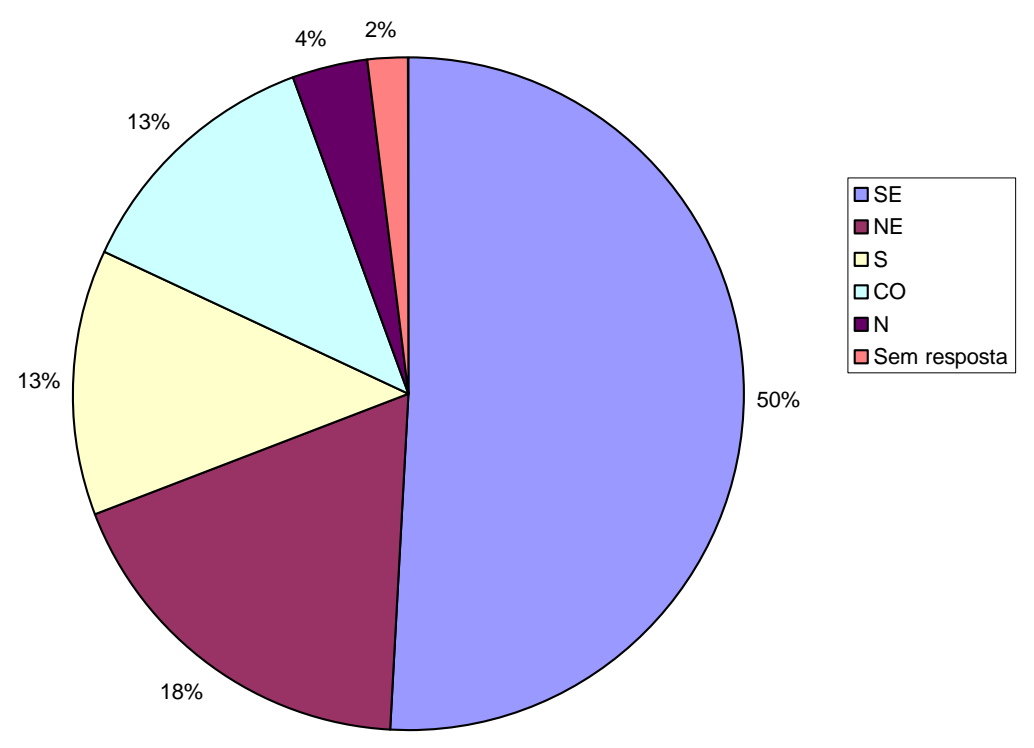

Fig. 2.33 Gráfico de usuários por região 


\begin{tabular}{|lr|}
\hline 4) Maior nível educacional \\
\hline Ensino Superior & 44 \\
Ensino Médio completo & 9 \\
Ensino Médio incompleto & 1 \\
Sem resposta & 1 \\
Ensino Fundamental & 0 \\
\hline Total & 56 \\
\hline
\end{tabular}

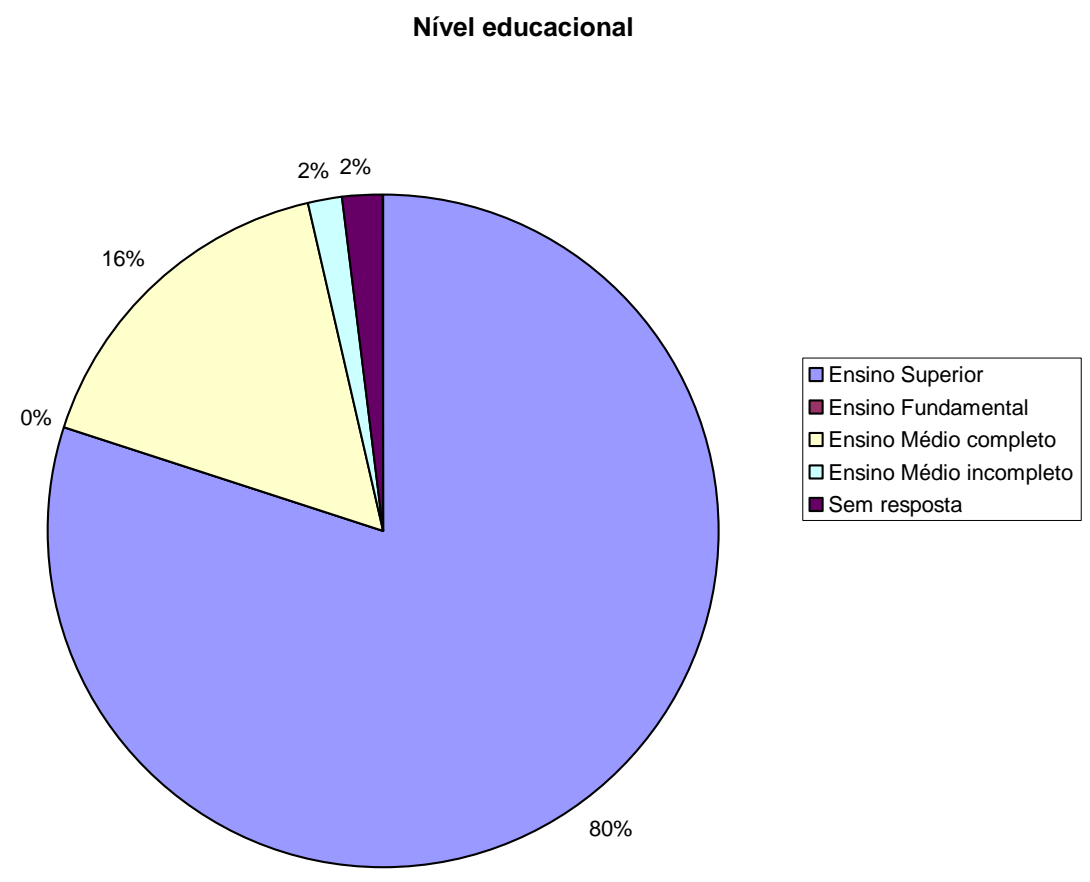

Fig. 2.34 Gráfico de usuários por nível educacional 


\begin{tabular}{|lr|}
\hline 5) Acesso ao CMI & \\
\hline Mais de 3 anos & 28 \\
Mais de 2 anos & 12 \\
Mais de 1 ano & 10 \\
Menos de 1 ano & 6 \\
\hline Total & 56 \\
\hline
\end{tabular}

Tempo há que acessa o CMI

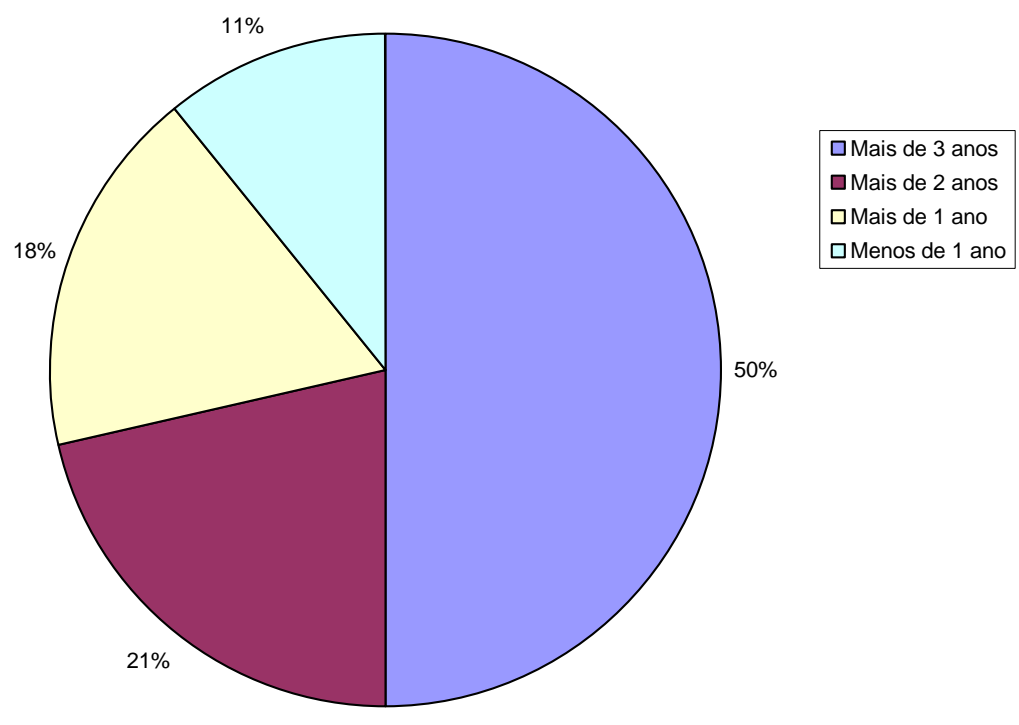

Fig. 2.35 Gráfico de usuários por tempo há que acessa o site do CMI 


\section{6) Orientação política}

Outra (especificadas: 5 "comunista", 2 "libertário", 2 "nenhuma")

Anarquista

Esquerda liberal

Esquerda autoritária

Sem resposta

Direita autoritária

Direita liberal

0
56

Orientação política

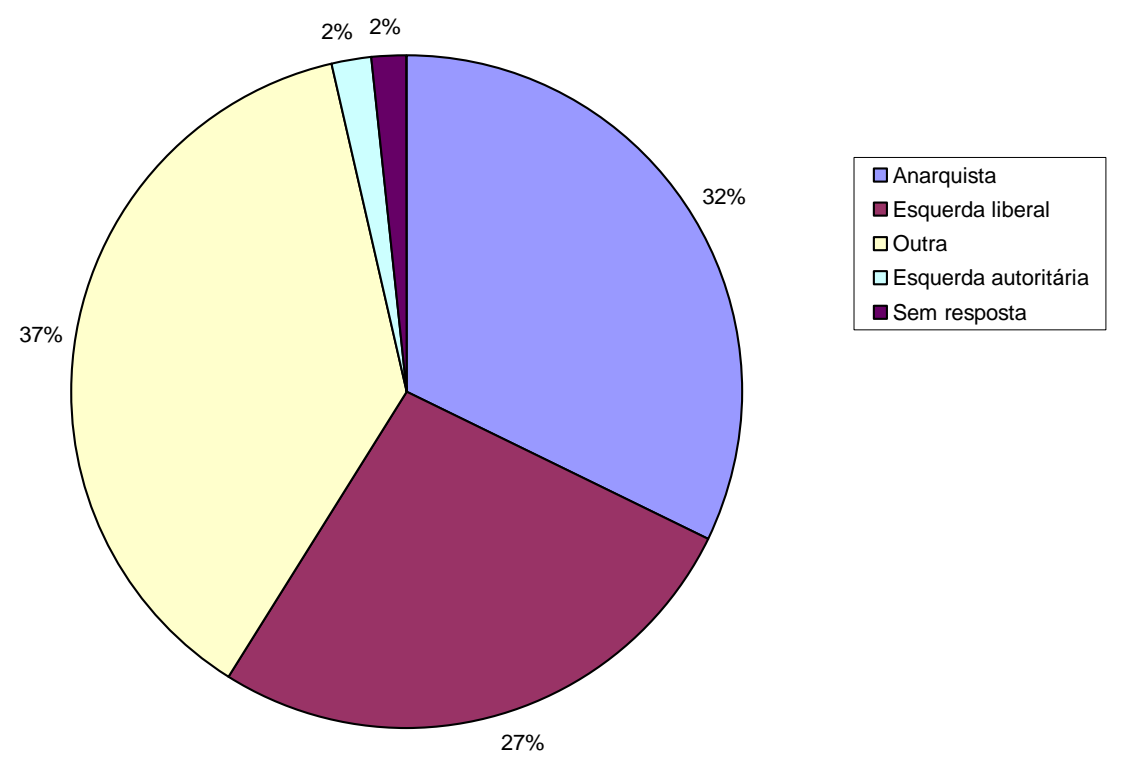

Fig. 2.36 Gráfico de usuários por orientação política 


\begin{tabular}{|l|r|}
\hline 7) Pertence a alguma organização ou movimento social? \\
\hline Sim & 34 \\
Não & 21 \\
Sem resposta & 1 \\
\hline Total & 56 \\
\hline
\end{tabular}

Pertence a alguma organização ou movimento social

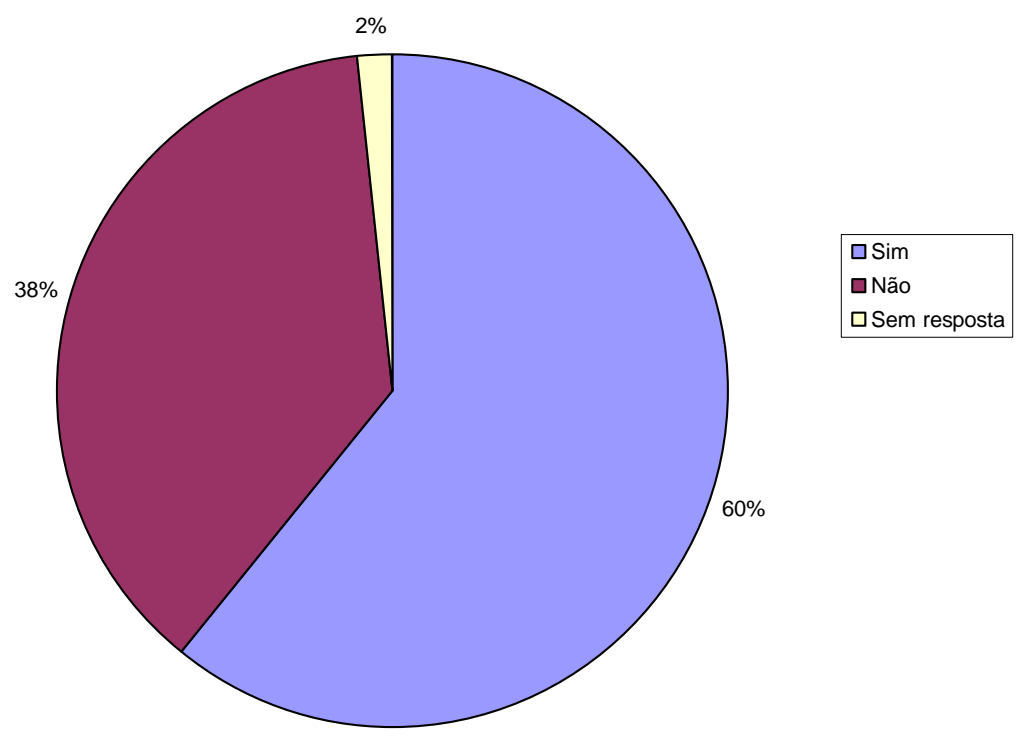

Fig. 2.37 Gráfico de usuários por participação ou não em organização ou movimento social 


\begin{tabular}{|l|r|}
\hline \multicolumn{2}{|l|}{ 8) Escreve em outro site ou blog } \\
\hline Sim & 48 \\
Não & 8 \\
\hline Total & 56 \\
\hline
\end{tabular}

Escreve em outro site ou blog

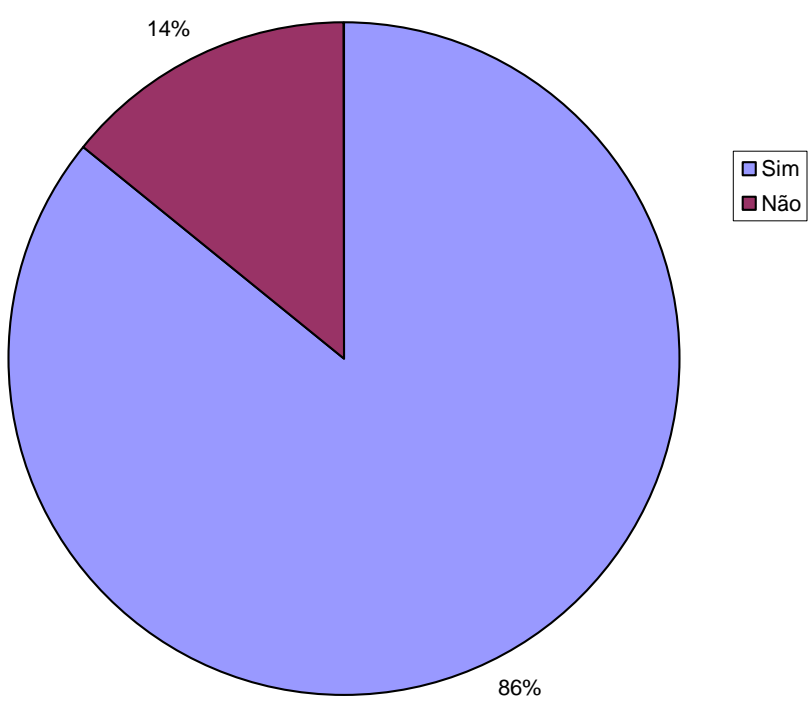

Fig. 2.38 Gráfico de usuários por participação ou não em outro site ou blog

\section{9) Tipo de texto predominantemente postado}

Observação: a maior parte dos respondentes selecionou mais de uma alternativa, por isso não apresentamos porcentagens.

Notícia redigida por você 31

Texto opinativo redigido por você 26

Notícia redigida por outra pessoa 8

Foto ou charge 2

Texto opinativo redigido por outra pessoa 2

Sem resposta 1




\begin{tabular}{|l|r|}
$\begin{array}{l}\text { 10) Participa/participou de reunião ou lista } \\
\text { de emails de coletivo do CMI }\end{array}$ \\
\hline Não & 45 \\
Sim & 8 \\
Sem resposta & 3 \\
\hline Total & 56 \\
\hline
\end{tabular}

Participa/participou de reunião ou lista de emails de coletivo do CMI

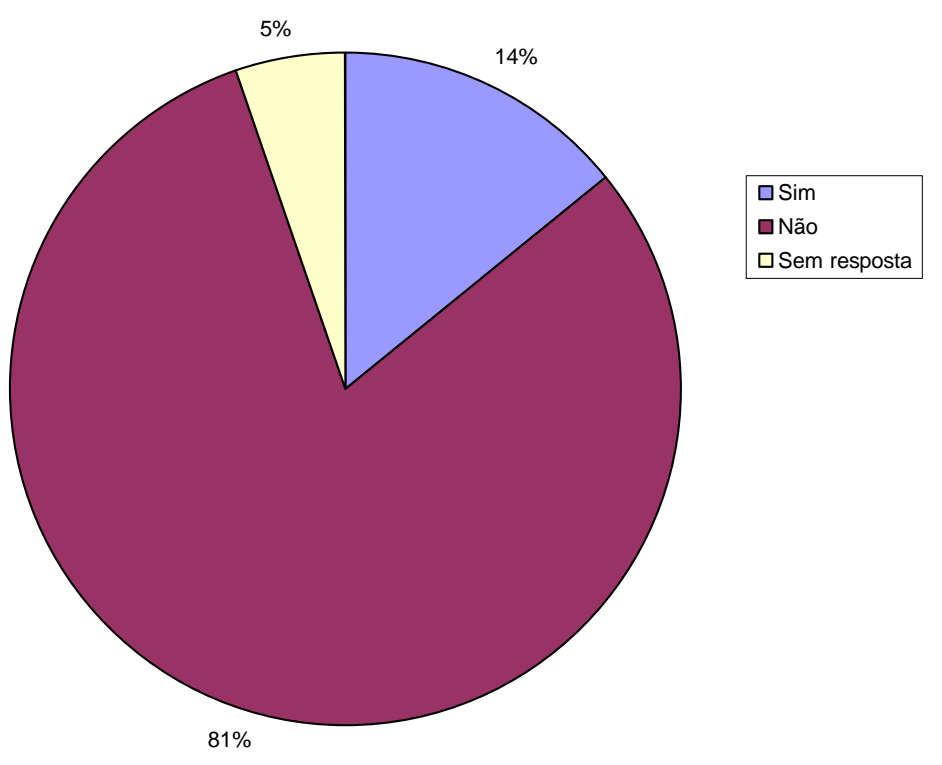

Fig. 2.39 Gráfico de usuários por participação ou não em reunião ou lista de emails de coletivo do CMI

\begin{tabular}{|l|r|}
\hline 11) Opinião/comentário \\
\hline Responderam & 43 \\
Sem resposta & 13 \\
\hline Total & 56 \\
\hline
\end{tabular}




\section{Comentários /opiniões enviados em resposta à questão 11 (aberta)}

O site é uma ótima realidade. Entretanto, falta união nos movimentos sociais para auxiliá-lo a ser o que pretende: um meio central de divulgação de vários movimentos sociais interligados, de forma independente, sem vincular-se a nenhum deles.

O site do CMI, como todos os outros, deve ser acessível às pessoas com deficiência visual ou cegas.

Utilizo o site como uma fonte alternativa e independente de informações, porém, muitas vezes o vejo tendencioso e pouco fundamentado. Louvo a iniciativa dos mantenedores do site e desprezo a mídia de massa das grandes emissoras.

Muito bom!!!

Vários anos depois de Seattle, estava na hora de rediscutir o que conta como progressista nas propostas iniciais do altermundismo. A seção de comentários é completamente dominada pela esquerda tradicional, e o site vergonhosamente apóia a esquerda autoritária andina sem nenhum senso crítico. O nível da maioria das notícias é desolador. O que vale mais são algumas notícias sobre atividades de movimentos sociais, e a política de publicação livre continua sendo uma boa ideia: só falta o site imaginar uma nova maneira de atrair leitores melhores.

Somos um coletivo (o Coletivo Libertário) e temos diferentes opiniões relativas sobre o CMI, mas no geral vemos o CMI como uma mídia liberal. Achamos que ela peca por não ter princípios nítidos, claros, na ânsia de trabalhar com 'todos'.

Além do mais, mantendo um discurso semi-libertário, o CMI pratica uma discriminação contra o Movimento Libertário Brasileiro (MLB), renegando sua existência e atividade e com isso se somando com a burguesia e o Estado que também negam nossa existência! Mas o CMI conta com aliados para manter esse discurso, são os assim chamados 'especifistas', que dizem que só vai existir movimento anarquista depois que eles dominarem tudo, o que é uma grande besteira! 


\begin{abstract}
É uma iniciativa muito importante, mas ultimamente a qualidade das matérias enviadas pelas pessoas tem caído bastante. É um desafio para o CMI. Mas sempre passo lá para saber das notícias sob um ponto de vista diferente.

É muito bom que exista o CMI! Abraços a toda a equipe.

O sítio virtual em questão auxilia o movimento social combativo a ter notícias sobre o que está acontecendo pelo Brasil, já que tais informações sempre precisam ser extraídas das grandes mídias através da análise do discurso e geralmente estão incompleta.

Representa o que temos de mais comprometido com o movimento social. É um canal fundamental para a divulgação das questões sociais pelo país. Não censura, não tem manipulação e podemos nos expressar livremente.

Atualmente devido à censura sionista e o medo do CMI em garantir a liberdade construtiva de expressão, eu e vários outros amigos estamos mais distantes. Dá pena a perda de mais um espaço democrático. A discussão e a beligerância entre extremos opostos via net, longe da ideia de racismo, por incrível que pareça, nos aproxima fraternalmente e é um elemento fundamental para a paz e uma harmonia forte e duradoura. Perdemos todos. Perdem judeus, cristãos, budistas e muçulmanos.
\end{abstract}

Eu considero o mesmo uma revolução de ideias.

O site é interessante pois aglutina bastante conteúdo intelectual, apesar de as vezes ser um tanto tendencioso em direção a argumentos esquerdistas. O que mais incomoda, no entanto, é a falta de moderação que evitasse a postagem de imensas bobagens e lixo textual, principalmente nos comentários das postagens.

Um site muito bom, que contribui com a democratização da mídia no Brasil.

O site tem sido usado de forma indiscriminada por panfletários dessa ou daquela organização, o que compromete a exposição de fatos noticiosos, por exemplo. Os comentários são muitas vezes vexatórios e agressivos. Por isso a sua credibilidade é 
abaladíssima como fonte de notícias.

Infelizmente, há algum tempo não tenho acompanhado o trabalho do CMI, mas quero me manter mais atualizado. Procuro interagir melhor com canais mais democráticos. Infelizmente ainda não populares.

Maravilhoso. Uma pequena semente rumo à informação livre e a democratização dos meios de comunicação.

O CMI Brasil é um jornal eletrônico sério, responsável, comprometido com os valores sociais, democrático, é uma luz, é um novo amanhecer, pois todos nós integrantes do CMI prezamos pelo respeito, pela cidadania, meus trabalhos nunca foram censurados, as questões colocadas no site, sempre são atuais, As minhas postagens geralmente são artigos, que levam a uma problematização do homem no espaço social, tratam na amplitude maior, geralmente, sobre as questões sociais, políticas, ambientais, estruturais da existência humana na postagem do universo curvo, planeta terra. - Brasil. Ser este pequena parte ligada ao CMI Brasil é ter a certeza de que esta tribuna livre é um altar mor de discussões, debates, questionamentos, sobre os problemas do Brasil, Entendo o CMI como a maior revista eletrônica do Brasil, pois aqui todos tem oportunidade, liberdade, seriedade e compromisso para com o desenvolvimento do Brasil.

O CMI, como um dos grandes veículos de mídia dos oprimidos, é aquilo que a mídia convencional não é, traz aquilo que os portais da Globo, Abril, etc. não trazem. Não fosse o CMI, dificilmente saberíamos algo sobre, por exemplo, a declaração de independência dos Lakota (que, a saber, poucas nações levaram a sério, infelizmente) e algumas atividades contra o abuso e exploração de animais. Tenho prazer de postar artigos no portal sabendo que isso ajuda, como tijolos na grande construção, a ao menos renovar as esperanças por um mundo mais justo.

O melhor sobre o CMI é sua abrangência.

Interessante. 
Muito bom site, liberal e anárquico histórico.

Sou devoto fiel do CMI e divulgo-o para todos que querem algo assim e que não o conhecem. É um exemplo, como o próprio nome diz, de independência, permitindo comentário sobre o que é publicado. Não censura, mas apenas coloca a publicação que fere a política editorial na seção Arquivos Escondidos. Só tenho elogios para esta iniciativa que existe em quase todos os países do planeta!

Parabéns.

Interativo, organizado, informativo, etc.

Desde quando conheci o CMI achei uma experiência interessante. Uma ferramenta de gente que participava de movimentações sociais e políticas e que não tinha os vícios comuns a organizações, como os partidos de esquerda burocratizados. Ultimamente tem perdido um pouco seu caráter e aos poucos vai se transformando num fórum opinativo, apesar de que ainda mantém sua estrutura básica, a cobertura jornalística própria (digo não do jornalismo formal) das movimentações sociais e políticas.

CMI desempenha um papel muito importante socializando informação e colocando em cheque a mídia corporativa. Espero que o CMI Brasil ainda mantenha o seu site por muitos anos.

O CMI tem um potencial enormemente desperdiçado, pois como mecanismo social de democratização da imprensa poderia lançar iniciativas, projetos e campanhas de forma mais atuante. A principal otimização a ser feita é a união dos coletivos estaduais em prol da disseminação desta nova forma de fazer mídia. O meio para ser eficiente deve ser visto (ou lido), e projetos de capacitação para produção de mídias poderiam fomentar esse processo. Uma boa ferramenta é a oficina de educomunicação. O NCE/USP possui um núcleo específico para o estudo desta tecnologia social. Vale a parceria.

Acho que o CMI é de extrema importância para o exercício democrático, e gostaria que fosse mais difundido fora da internet. 


\begin{abstract}
Bom para democratizar informações de esquerda e da mídia alternativa
Onde se encontra a verdade sobre os fatos.

Um site fundamental para a democratização da produção e distribuição da informação! Mantenham o bom trabalho!

Muito bom mesmo. No entanto, se houvesse mais divulgação poderia estar sendo melhor aproveitado e beneficiando a formação social e política de mais quantas pessoas?! Por exemplo: hoje existem milhares de bibliotecas virtuais nas escolas públicas onde, gratuitamente, milhões de alunos de todas as séries acessam alguns endereços na internet. Sugiro uma parceria com esses municípios. Na minha cidade, por exemplo, existe um espaço desses em cada bairro da cidade, aberto à comunidade em geral, além de salas com computadores em cada escola, inclusive nas da zona rural. Também poderiam levar o CMI aos sindicatos patronais e de trabalhadores; as associações de bairros, aos clubes de serviços, aos órgãos e entidades sociais, culturais e afins, enfim... Nada lhes custaria e o resultado seria fantástico. O que este país precisa é de mais e mais e mais cabeças pensantes. O CMI pode mais que isso.
\end{abstract}

Espaço importante de contraposição à mídia convencional de divulgação das notícias dos movimentos sociais, que não aparecem em outros veículos de comunicação.

O CMI é muito legal, mas de tempos para cá as pessoas estão escrevendo mais anonimamente, escrevendo muitas besteiras só para provocar os outros.

O CMI é ou procura ser um espaço de debate livre de ideias, tão livre que ás vezes até deixa os idiotas dos analfabetos PENTECOSTAIS ficarem postando suas idiotices superficiais, que só servem para vender os dois produtos deles: $\mathrm{O}$ tal do Cristo e o tal do Diabo, quando um mais lucrativo do que o outro. Alguns anarquistas dizem que na rede de voluntários do CMI há até SKINHEADS de direita infiltrados. Não duvidaria de nada disso. Afinal eu acredito que a direita seja SKINHEAD, ou seja, PENTECOSTAL é capaz de qualquer coisa. Aliás, eu tenho mais medo dos PENTECOSTAIS do que dos SKINHEADS. Eu cheguei a me envolver com um, por causa de vacilo meu, 


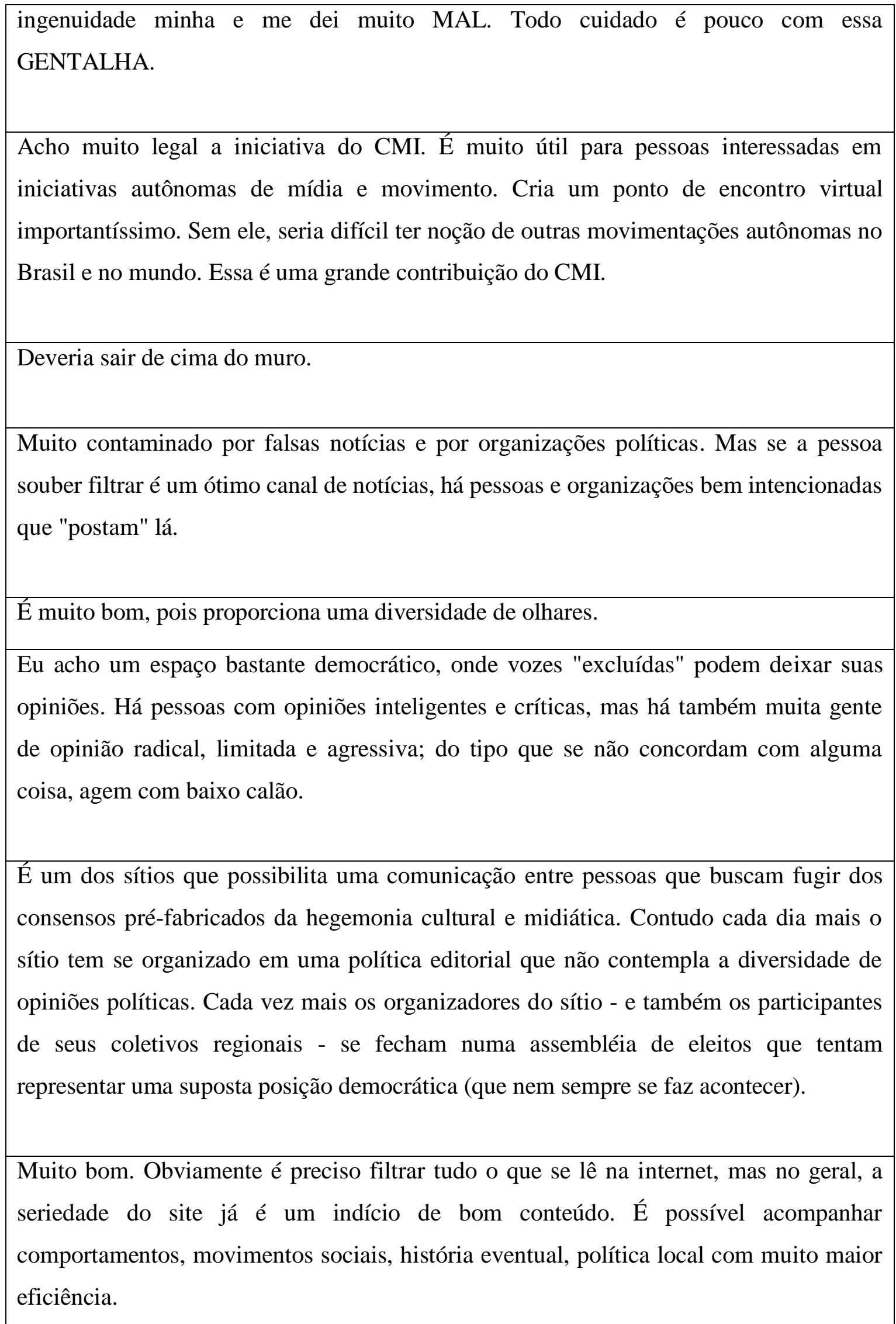


2.2 Considerações a partir dos resultados - pesquisa com usuários da coluna da direita

Alguns resultados obtidos na pesquisa com os usuários da coluna da direita do CMI nos chamam imediatamente a atenção. Por definição, já que um dos seus grandes objetivos é a abertura da mídia, o CMI é uma iniciativa que busca contemplar a maior diversidade possível do público sintonizado com objetivos semelhantes.

Porém, ao menos na seção do site que aqui analisamos, há algumas "maiorias esmagadoras" ou pelo menos números expressivos que demonstram não ser esta a realidade - a não ser que todas as pessoas sintonizadas com estes objetivos tenham um perfil muito homogêneo. Não acreditamos ser esta segunda hipótese o caso, porque os objetivos da Rede Indymedia contemplam metas bastante gerais, e de certa maneira comuns entre grande parte dos participantes de movimentos sociais e de contestação da ordem contemporâneos.

Quanto à explicação para por que isto acontece, no escopo delimitado desta pesquisa, apenas a formulação de hipóteses é possível - mas acreditamos que a simples constatação do que acontece, e a produção de um certo estranhamento e curiosidade - ainda que não chegando a explicações fechadas - já é um passo bastante importante na reflexão sobre a práxis do veículo que estudamos, e até da temática mídia alternativa e/ou de movimentos sociais como um todo.

Vamos então discutir estes dados e maiorias que nos chamam a atenção.

\section{Assuntos e formatos: texto opinativo, política e a desobediência à política editorial}

- Por que $12 \%$ do conteúdo que analisamos não tem relação com a política editorial - ao menos em nossa visão, quando comparamos o que está escrito na política editorial com o assunto da postagem - e ainda assim permanece junto das demais postagens? Há, entre os moderadores, um forte receio em remover postagens que não apresentem casos extremos de violação da política editorial, como as racistas ou que citem partidos políticos? Ou faltam ‘braços' voluntários para uma moderação mais criteriosa? 
- Considerando que o CMI se pretende uma mídia de conteúdo em grande parte jornalístico (novamente, baseando-se no que está escrito na política editorial: "publicar sua própria versão dos fatos"; romper "o papel de espectador(a) passivo/a" e transformar "a prática midiática"; "colocando no ar notícias, artigos, comentários, fotos, áudios e vídeos; e promovendo o "rompimento da mediação do/a jornalista profissional (...) no conteúdo das matérias"), 46\% não é um número muito alto para o formato "texto opinativo", isto é, sem atualidade e o outras características necessárias para que sejam considerados notícias ${ }^{21}$ ?

- Por que não apareceram postagens em política internacional cujo assunto fosse o continente africano - para que o mesmo ganhasse uma categoria própria, ou em que não fosse a região mencionada apenas para falar da questão do negro e do racismo? As questões que envolvem Estados Unidos, Europa e Oriente Médio (para não falar da América Latina, cuja proximidade e afinidade com questões brasileiras de certo modo justificam a preponderância nos assuntos) têm mais importância para quem se envolve - seja participando, seja só acompanhando - com a temática dos movimentos sociais no Brasil? Poderíamos nos perguntar o mesmo sobre outras regiões da Ásia que não o Oriente Médio, mas a África nos chama atenção pela relação histórica com o Brasil e pela situação social emergencial em que se encontram muitos países deste continente.

\section{Usuários: homens do sudeste com mais de 35 anos e ensino superior}

- Ao menos 78\% dos usuários da coluna da direita serem homens é um número assustador. O que faz o público feminino participar tão pouco da seção? Será que a proporção de mulheres envolvidas com as questões políticas ainda é tão menor que a de homens? Ou há algo específico da estrutura do site que as atrai menos à participação?

- 43\% dos usuários têm mais de 35 anos. O que nos causaria mais estranhamento e até a impressão de que o público mais velho é quem domina o CMI

\footnotetext{
${ }^{21}$ A discussão teórica dos conceitos de notícia - entre os quais o componente de atualidade ou correspondentes quase sempre aparecem - em que nos baseamos para esta pesquisa está em: Kovach e Rosenstiel, 2003; Lage, 1985; Traquina, 2004.
} 
se, ao ter contato com os organizadores e voluntários do site não tivéssemos visto e maior variedade etária (o que foi confirmado pela entrevistada Foz no Capítulo 2, página 167), mesmo que não tenhamos empreendido pesquisa empírica desta natureza com este outro grupo. Podemos supor que o público que posta na coluna da direita $50 \%$ há mais de 3 anos e $21 \%$ há mais de 2 anos - é um público fiel, já acostumado com a dinâmica do site, bem acessível do ponto de vista técnico e que quase não mudou ao longo dos anos. O que, por outro lado, também pode ter afastado os mais jovens, em contato com uma variedade maior de ferramentas tecnológicas, mais facilmente adaptáveis a mudanças constantes e inovações, e até atraído pelas mesmas.

Podemos também apenas conjecturar sobre a influência recíproca de idade e sexo dos participantes na preponderância temática. Pode ser que textos opinativos sobre política geral ou sobre política nacional sejam assunto e formato da preferência de homens maiores de 35 anos, que por isso os contemplam em suas postagens. Será que um público mais feminino e mais jovem não alteraria essa preponderância temática e de formato? E, na outra via, é possível que o público feminino e mais jovem, ao ter contato com tantas postagens com este formato e assunto, não se sinta desmotivado a participar?

- O fato de $80 \%$ dos participantes apresentarem ensino superior completo ou incompleto é mais um dado expressivo. Com raciocínios semelhantes aos expostos no item anterior, podemos relacionar este perfil dos usuários com a preponderância temática das postagens. Outro aspecto a ser pensando, considerando que ensino superior é um traço mais comum a um público de origem social favorecida, é a dificuldade de pessoas com condições econômicas e educacionais ruins em participarem de iniciativas que têm a internet como vetor. Mas não só a chamada “exclusão digital” é a responsável. A literatura sobre novos movimentos sociais anterior à difusão da internet já apontara a classe média de nível universitário como ator principal:

A análise desenvolvida por Habermas trata os movimentos como indicadores do potencial de crise do capitalismo tardio. Em sua obra Teoria da ação comunicativa, ele identifica os novos movimentos sociais com a resistência defensiva aos processos de extensão da racionalidade técnica dentro de todas as esferas da vida social. (...) Para o autor, os novos problemas sociais têm relação com qualidade de vida, igualdade de direitos, auto-realização individual, 
participação e direitos humanos. Contrastando com a velha política dos trabalhadores, a nova política advinda dos novos movimentos sociais advém basicamente da nova classe média, da geração dos jovens e dos grupos sociais com mais alto grau educacional. (Gohn, 1997, p.140)

Acrescentamos que tempo e recursos materiais disponíveis, bem como maior acesso a informações que estimulam uma postura crítica e politizada são motivos de ordem prática prováveis.

- Sobre a questão da "orientação política" dos participantes, 32\% se declararem anarquistas é um número até menor do que seria esperado, já que a estrutura de funcionamento do CMI Brasil claramente segue tendências anarquistas e libertárias (autogestão, decisões por consenso e não por maioria, e sem hierarquia formal). O nosso contato com voluntários que participam de reuniões, listas e da manutenção em si do veículo permitiu notar - ainda que não contabilizássemos isto - a quase totalidade desta orientação política (ou pelo menos simpatia pela sua ideologia) entre este outro grupo.

- 61\% participarem de algum movimento social, apesar de maioria, ainda é um número pequeno, em nossa opinião. $37 \%$ deste público apenas escreve sobre política e movimentos sociais, sem um envolvimento direto e prático? Em caso afirmativo, isso nos lembra a expressão irônica "revolucionários de sofá", e também nos faz reforçar a impressão de que há uma tendência de esvaziamento na participação dos movimentos sociais atualmente. Mas é preciso fazer a ressalva de que é possível que parte deste público não tenha declarado fazer parte de um movimento ou organização específico, mas participe de iniciativas variadas de alguns deles: manifestações, protestos, etc. Dentro do escopo desta pesquisa, não foi possível determinar isto.

- O fato de no mínimo $81 \%$ do público analisado que posta na coluna direita nunca ter participado de uma reunião presencial de um coletivo do CMI e nem sequer estar integrado em uma das listas de email do CMI é bastante notável. Poderíamos dizer que o público que posta nesta seção não tem um conhecimento razoável das atividades do CMI ou mesmo da sua dinâmica de funcionamento, só utilizando o site como um canal onde podem postar à vontade e serem mais lidos do que o seriam em 
um blog pessoal. Isso talvez explique a "desobediência" à política editorial que constatamos nesta seção, e mesmo a divergência de perfil e temáticas abordadas que notamos entre o público que posta na coluna da direita e o grupo que mantém de fato o site (os "voluntários").

Reafirmamos que apenas uma outra pesquisa que contemplasse esses aspectos junto aos participantes poderia esclarecer a validade dessas hipóteses. Mas, novamente enfatizamos, avaliamos ser de alguma utilidade já o fato de levantá-las, estimulando futuras pesquisas e mesmo os usuários e voluntários do site a refletirem sobre as questões colocadas em evidência.

As respostas à questão em que se pedia para deixar um comentário sobre o CMI, em alguns casos, reforçam a hipótese de desconhecimento do projeto:

- "Há pessoas com opiniões inteligentes e críticas, mas há também muita gente de opinião radical, limitada e agressiva; do tipo que se não concordam com alguma coisa, agem com baixo calão.” - Divulgação de opiniões não é a meta do site.

- “As minhas postagens geralmente são artigos, que levam a uma problematização do homem no espaço social, tratam na amplitude maior, geralmente, sobre as questões sociais, políticas, ambientais, estruturais da existência humana na postagem do universo curvo, planeta terra. - Brasil." - Divulgação deste gênero de artigos não é a meta do site.

- "O site é interessante pois aglutina bastante conteúdo intelectual, apesar de as vezes ser um tanto tendencioso em direção a argumentos esquerdistas." - Divulgação de conteúdo intelectual não é a meta do site, não se trata de uma biblioteca virtual de artigos.

- "Deveria sair de cima do muro." - O CMI tem uma linha e uma política editoriais bem claras, mesmo que talvez não tão conhecidas. Se o usuário está chamando de "sair de cima do muro" assumir orientações partidárias, aí o desconhecimento fica mais patente. 
Em outros casos, porém, estas respostas reafirmam crenças que apareceram nas entrevistas com os organizadores, e mesmo críticas pertinentes:

- "O que vale mais são algumas notícias sobre atividades de movimentos sociais, e a política de publicação livre continua sendo uma boa ideia: só falta o site imaginar uma nova maneira de atrair leitores melhores."

- "O que mais incomoda, no entanto, é a falta de moderação que evitasse a postagem de imensas bobagens e lixo textual, principalmente nos comentários das postagens."

- "O site tem sido usado de forma indiscriminada por panfletários dessa ou daquela organização, o que compromete a exposição de fatos noticiosos, por exemplo. Os comentários são muitas vezes vexatórios e agressivos. Por isso a sua credibilidade é abaladíssima como fonte de notícias." - Comentários agressivos são constantemente encontrados.

- "Procuro interagir melhor com canais mais democráticos [como o CMI]. Infelizmente ainda não populares." - de fato, o CMI ainda não tem uma prática que pode ser chamada de jornalismo popular, já que ainda há mediação, como discutiremos mais à frente.

- "É uma iniciativa muito importante, mas ultimamente a qualidade das matérias enviadas pelas pessoas tem caído bastante. É um desafio para o CMI. Mas sempre passo lá para saber das notícias sob um ponto de vista diferente”. - Há realmente, mesmo na coluna central, matérias cuja qualidade jornalística (apuração, fontes, boa redação, que facilite o entendimento do leitor) deixa a desejar.

- "Não fosse o CMI, dificilmente saberíamos algo sobre, por exemplo, a declaração de independência dos Lakota." - Aqui aparece um dos principais diferenciais do CMI: publicar o que não se publica em outros veículos da mídia. 
- "Sem ele, seria difícil ter noção de outras movimentações autônomas no Brasil e no mundo. Essa é uma grande contribuição do CMI.” - O mesmo dito em relação ao comentário anterior se aplica aqui.

- "Uma ferramenta de gente que participava de movimentações sociais e políticas e que não tinha os vícios comuns a organizações, como os partidos de esquerda burocratizados. Ultimamente tem perdido um pouco seu caráter e aos poucos vai se transformando num fórum opinativo." - Crítica pertinente, e mostra conhecer o histórico do CMI. 


\section{Capítulo 3}

\section{Quem faz a mídia no CMI - voluntários e organizadores}

\subsection{Metodologia - pesquisa com voluntários e organizadores do CMI}

Do ponto de vista das ciências humanas, qualquer pesquisa que investigue agrupamentos de pessoas sempre trabalham com significados, motivações, valores e crenças, que são noções muito particulares. Assim, nem sempre é suficiente a simples coleta de dados por meio de questionário fechado. No caso da pesquisa com os usuários da coluna da direita esta metodologia teve sua utilidade, já que se trata de um grupo, até onde tenhamos conhecimento, nunca antes pesquisado, e cujos dados que obtivemos trazem indicativos inéditos e passíveis de reflexão. Além de trabalharmos com um grupo de pessoas bem maior, e de localização bastante heterogênea, o que dificultaria entrevistas pessoalmente, os resultados que obtivemos já preenchem - ao menos no escopo específico desta pesquisa - as lacunas de informações que pretendíamos em relação àquele grupo.

Já em relação aos voluntários organizadores do CMI, a meta foi outra. Optamos por focalizar os valores, discursos e estilos de vida do grupo pesquisado, abrindo mão de catalogar dados mais "concretos" como, por exemplo, idade, região e sexo, em prol de uma investigação de nível mais profundo. Assim, em primeiro lugar, realizamos uma observação assistemática, para conhecer o grupo e o funcionamento de suas atividades. Enviamos email para a lista do coletivo em São Paulo do CMI, e nos foi aberta a possibilidade de participação em reuniões. Esta participação, aliás, é aberta a qualquer pessoa que os contate, bastando para isso uma breve apresentação. Aproveitamos a oportunidade destes encontros, que acompanhamos durante os anos de 2008 e 2009, para conhecer o grupo, e também realizar contatos para as entrevistas planejadas.

Alguns contatados optaram pela não participação nas entrevistas. Outros foram avessos no começo - um "espírito antiacadêmico" que observamos, talvez por toda carga de autoritarismo, hierarquia e não democratização do conhecimento muitas vezes associada às universidades, como inclusive apareceu explicitamente em algumas 
de suas justificativas para a negativa. Mas após ficarem mais claras as intenções da pesquisadora, simpatizante de alguns dos ideais do grupo - o que não julgamos ser um problema revelar, para não manter uma neutralidade artificial - acabaram concordando em participar.

O número de voluntários contatados foi bem menor, porém as entrevistas foram feitas pessoalmente, com duração entre uma e duas horas, e sem um esquema rígido de perguntas, que não permitisse desvios e digressões - tanto do entrevistado quanto da entrevistadora: a chamada entrevista aberta.

A técnica de entrevistas abertas atende principalmente finalidades exploratórias, e é bastante utilizada para o detalhamento de questões e formulação mais precisas dos conceitos relacionados. Em relação a sua estruturação, o entrevistador introduz o tema e o entrevistado tem liberdade para discorrer sobre o tema sugerido. É uma forma de poder explorar mais amplamente uma questão. As perguntas são respondidas dentro de uma conversação informal. A interferência do entrevistador deve ser a mínima possível, este deve assumir uma postura de ouvinte e apenas em caso de extrema necessidade, ou para evitar o término precoce da entrevista, pode interromper a fala do informante. (Boni e Quaresma, 2005, p.74)

Assim, procuramos traçar um pré-roteiro com perguntas que julgamos pertinentes ao nosso objetivo - revelar as crenças, valores e hábitos de cada entrevistado, bem como detalhar melhor o funcionamento do grupo (CMI) ao qual ele pertence - somando-se a isso as perguntas que surgiam como válidas no decorrer da entrevista.

Também não foram exatamente iguais os roteiros pré-estabelecidos para cada entrevistado. Por já termos algum contato anterior com cada um deles e conhecer sumariamente sua atuação no grupo, elaboramos as perguntas que achávamos mais adequadas àquele entrevistado específico. Porém, em todas as entrevistas procuramos fazê-los refletir, do ponto de vista da comunicação, da tecnologia e dos movimentos sociais, sobre suas práticas, e expor estas reflexões. A trajetória do entrevistado no CMI também foi levantada em todas elas, por meio da chamada história de vida tópica.

Com relação à história de vida (HV), [...] abordaremos como uma entrevista em profundidade na qual o pesquisador constantemente interage com o 
informante. Sua principal função é retratar as experiências vivenciadas por pessoas, grupos ou organizações. Existem dois tipos de HV: a completa, que retrata todo o conjunto da experiência vivida, e a tópica, que focaliza uma etapa ou um determinado setor da experiência em questão (Minayo, 1993). A HV tem como ponto principal permitir que o informante retome sua vivência de forma retrospectiva. Muitas vezes durante a entrevista acontece a liberação de pensamentos reprimidos que chegam ao entrevistador em tom de confidência. Esses relatos fornecem um material extremamente rico para análise. Neles se encontram o reflexo da dimensão coletiva a partir da visão individual. (Boni e Quaresma, 2005)

A edição das entrevistas foi feita de modo a propiciar maior legibilidade, sendo adaptadas para a linguagem escrita unicamente características próprias de linguagem oral que atrapalhariam o entendimento do leitor. Ainda assim, as entrevistas transcritas foram enviadas por email para cada um dos entrevistados, que tinham a opção eles mesmos de editarem, suprimirem ou acrescentaren informações - embora a maior parte tenha preferido não fazê-lo. Antes da realização da entrevista, deixamos claro que teriam esta possibilidade, contribuindo assim para tranquilizá-los em falar à vontade.

Apesar de trechos serem expostos ao longo dos capítulos, essas entrevistas serão dispostas aqui na sua integralidade, pois consideramos que a leitura completa de cada uma delas proporciona narrativas coerentes úteis aos nossos propósitos neste trabalho, e um conhecimento mais contextualizado de cada entrevistado. Porém, antes de cada uma delas, destacamos os assuntos mais abordados na ocasião e tecemos alguns comentários. 


\subsection{Entrevistas}

\section{Pablo Ortellado}

Consideramos esta primeira entrevista muito importante, por se tratar de um dos primeiros voluntários do CMI Brasil, já afastado das atividades, mas que teve papel de destaque na montagem do coletivo nacional, em 2001. Bem mais do que mostrar, a partir das respostas, um pouco do seu perfil, o entrevistado nos dá um relato valioso do histórico do CMI e uma análise pessoal, de alguém com muito conhecimento neste aspecto, do empreendimento CMI no bojo do contexto em que surgiu.

Chama a atenção, primeiramente, o diagnóstico que faz sobre a evolução do CMI e o principal acontecimento que o forjou: o movimento antiglobalização. Para Pablo, a meta deste movimento era unificar todas as lutas sociais - operária, ambientalista, feminista, étnica, entre outras - contra um inimigo em comum que as atingia: o processo de liberalização econômica. A Rede Indymedia seria então o veículo da convergência destes movimentos, dando espaço às suas questões específicas e também às comuns. E o CMI nacional, do qual participou da criação, seria o espaço para isso no Brasil. Em sua visão, porém, do mesmo modo como o movimento antiglobalização não teve êxito em fazer estas lutas convergirem na prática, o projeto do CMI também não o fez - embora ele veja um grande valor no fato de o veículo manter lado a lado, sem preferência para um ou outro, conteúdos dos diversos movimentos.

Pablo também valoriza bastante o fato de os sites da Rede Indymedia terem sido os primeiros a utilizarem extensivamente a publicação aberta, que hoje se banalizou com blogs e outros recursos que permitem a expressão de qualquer pessoa na internet. Mesmo com esta banalização, um site como o CMI, por ter sido pioneiro, ainda é a referência neste aspecto, em particular para participantes de movimentos sociais e lutas políticas que desejam divulgar informações. Atualmente professor universitário, e com algum contato com estas temáticas, ele reclama do fato de a literatura sobre jornalismo colaborativo ou cidadão ter quase que "apagado" da história a iniciativa do CMI e da Rede Indymedia como um todo. Na internet brasileira, segundo Pablo, ainda não há nenhum veículo do gênero que supere o CMI em importância e mesmo em número de acessos. 
O entrevistado acredita, entretanto, que o CMI precisa se reformular, tanto do ponto de vista de seu projeto ideológico quanto tecnológico, para perder a característica de anacrônico que adquiriu nestes pontos e readquirir a importância que teve em 2001, por exemplo. Critica uma certa "guetização" do grupo que o mantém no Brasil, muito ligado à política autonomista e antipartidária. Afirma ainda que a cobertura realizada pelos voluntários do CMI por vezes deixa a desejar em quesitos como apuração e checagem, e que por ser uma cobertura não profissional, livre das pressões, teria que ser infinitamente superior à da mídia convencional. Para Pablo, falta também interesse em refletir mais sobre questões do jornalismo e da comunicação relacionadas à prática do veículo.

\section{Conte um pouco da formação do CMI no Brasil, e do seu papel nisso.}

Quando o Indymedia nasceu em Seattle, muito vinculado ao movimento antiglobalização - em particular contra a OMC, em 1999 -, o objetivo inicial era bem diferente do que é atualmente. Se você pegar os primeiros documentos, a idéia era um pouco a da Ciranda da Informação, aquele grupo ligado ao Fórum Social Mundial. Era fazer um site de trabalho cooperativo, no qual diferentes veículos independentes colaborariam, sem direitos autorais, por ele ser livre, de maneira que substituísse uma cobertura concorrente por uma cobertura cooperativa. Eu poderia pegar todas as entrevistas que outros veículos fizessem e que pudessem servir para o meu veículo, e a mesma coisa com as minhas entrevistas. Ele já nasceu muito multimídia, embora em 1999, por exemplo, a possibilidade de você fazer vídeo efetivamente fosse muito pequena, porque os vídeos eram pesados e a qualidade era baixa. Mas já se deixava claro no projeto que ele poderia ter vídeo, texto, áudio e imagem - os quatro tipos de mídia.

Durante os protestos de 1999, as pessoas se apropriaram dos veículos de comunicação, e ele mudou completamente a cara. Então, ele deixou de ser um projeto de jornalistas que estariam cooperando, e passou a ser um projeto no qual as pessoas seriam os verdadeiros atores. Esse foi um entendimento com que o próprio público da internet estava sinalizando. No momento em que se desenhou o site poderiam entrar apenas pessoas cadastradas. Mas, por uma opção de alguns desenvolvedores é que a característica de publicação aberta foi incorporada. Foi uma casualidade. A ideia de que qualquer um pudesse publicar foi uma casualidade, porque eles usaram uma plataforma que já existia e que já tinha sido usada pelo movimento antiglobalização 
no ano de 98, e adaptaram para aquela circunstância. Ele a incorporou. E sendo possível publicar abertamente, as pessoas fizeram uso maciço do site, que então deixou de ser feito por veículos de comunicação para ser feito pelas pessoas. E passou a ter um projeto próprio, com o espírito da publicação aberta. Essa foi a evolução. Isso só ficou claro em meados de novembro e dezembro de 99. Porque o site foi ao ar poucos dias antes do protesto - o protesto foi no dia 30 de novembro - e ele passou a ser utilizado dessa maneira.

Digamos que essa consciência se formou entre dezembro de 1999 e janeiro de 2000. Imediatamente depois, o Indymedia começou a se descentralizar, mais ou menos acompanhando os protestos contra os organismos internacionais. Era um pouco a lógica do movimento naquela época, de a gente fazer encontros tentando barrar os encontros dos organismos mundiais: OMC, FMI, Banco Mundial, G8. Em cada lugar onde acontecia um desses protestos, tinha um CMI. O primeiro da América Latina, que foi o do México, era um movimento muito forte, de um dos grupos que estava ligado nessa rede de grupos autônomos mundiais que se formou na história do movimento antiglobalização. Então foi para o México, e acho que depois foi pra Bolívia, e depois para o Brasil.

Quando o CMI Brasil foi criado, a gente já tinha o entendimento da publicação aberta como coração do nosso projeto - isso já tinha se consolidado imediatamente após Seattle. Mas, ao mesmo tempo, o que confundia muito o projeto do CMI com o projeto do movimento antiglobalização, é que o CMI era o veículo oficial de comunicação do movimento antiglobalização. Só que esse movimento antiglobalização tinha uma ambiguidade, que era ser por um lado um novo movimento social e por outro se apresentar apenas como uma convergência de todos os movimentos. O nosso discurso em 2000 era: "nós estamos superando a fragmentação dos movimentos dos anos 60 e 70". Houve um histórico que vai do final do século XIX, até os anos 70, onde o movimento social estava atuando sob o guarda-chuva do movimento operário. Nos anos 70 ele se fragmenta com a luta das mulheres, dos negros, dos jovens, e a luta ecológica.

O movimento de antiglobalização faria a convergência dessas lutas. O processo de liberalização econômica estava fazendo com que essas lutas convergissem do ponto de vista prático, porque ele afetava simultaneamente todas elas. Parecia, de longe, uma coisa sem pé nem cabeça, um movimento que não sabia o que era. Mas isso era para quem estava olhando de fora, porque para gente era exatamente isso: o 
processo de liberalização econômica estava afetando todos esses movimentos e permitia que a gente construísse uma plataforma comum. Na verdade, em muitas ocasiões, o movimento antiglobalização efetivamente foi isso: a convergência de todos esses movimentos. No entanto, teve uma parte de ativistas - em particular os politicamente mais ligados aos grupos autônomos - que o tomaram em sua primeira causa. Tinha gente fazendo militância antiglobalização e ponto: não estava necessariamente vinculada a algumas dessas causas que convergiam. E às vezes, dependendo de como a gente fala "movimento antiglobalização" no sentido estrito, estamos falando dos grupos que tomaram a liderança dos processos de 1998 até 2002. Eram grupos, do ponto de vista político, bem horizontalistas, e eram principalmente jovens urbanos, mas, dependendo do país, também grupos camponeses. O CMI também permitiu que diversos grupos que estavam atuando se encontrassem na parte de comunicação.

\section{E sua participação dentro desse processo?}

Em 1999, para quem estava mais ou menos envolvido no campo político, ficou claro que havia uma movimentação, que estava surgindo alguma coisa, muito antes de Seattle.

No primeiro período, quem efetivamente liderou o movimento antiglobalização no mundo inteiro foram grupos de jovens urbanos que estavam ligados a uma rede chamada Ação Global dos Povos (AGP), porque foi a partir daí que nasceram os Dias de Ação Global. Era uma rede que tinha um objetivo: protestar durante os dias de encontros de organismos multilaterais, como o G8. Seriam, digamos, manifestações e ações diretas em diversas cidades do mundo pressionando contra essas instituições multilaterais. Essa estratégia que foi definida pela AGP foi o germe, na minha leitura.

Então esse era um processo que já vinha acontecendo, já tinha grupo em São Paulo se organizando nesse sentido. Nossa primeira manifestação mais séria foi no $1^{\circ}$ de maio de 2000. E depois, em 26 de setembro, foi nossa estreia mesmo, em São Paulo, com o movimento bem organizado e tal. Então, durante o ano 2000, imediatamente após Seattle, a gente teve um processo de preparação e de edição do movimento. E o CMI era uma parte disso, de uma maneira muito individualizada. Eram dois grupos, e tinha gente que estava no movimento antiglobalização, mas não 
estava no CMI; mas não havia no CMI quem não estivesse no movimento antiglobalização.

\section{Como você definiria o CMI?}

Porque o CMI é um conjunto de projetos, ele é de difícil definição. Diria que o CMI é uma rede de mídia que busca promover a capacidade das pessoas falarem por si próprias. De maneira vaga acho que é alguma coisa assim. Quando incluímos esse conceito de publicação aberta, o site Indymedia teve mais de um milhão de acessos, no final de novembro de 1999. Enfim, foi um marco na história da comunicação quando não tinha blog e outras ferramentas como hoje, em você publica à vontade. $\mathrm{Na}$ época tinha os grandes portais, onde os analistas escreviam. Os sites pessoais eram muitos pequenos.

\section{Que outros projetos são estes do conjunto que você falou?}

Produção de vídeo, rádio comunitária, canal web, jornal-mural, cyber café, vários. Cada coletivo tem as suas dezenas de projetos.

E qual é a relação dos movimentos sociais com o CMI? As pessoas que fazem parte de um movimento social buscam o CMI como um canal? Como funciona isso?

Ele nasceu como um veículo do movimento. Quem o fazia eram as pessoas do movimento antiglobalização no sentido estrito, aqueles que se dedicavam ao movimento antiglobalização. E era praticamente só usado pelo movimento antiglobalização. Por outro lado, ele tinha de ser a convergência. Então era tudo: o movimento feminista, movimento verde. A primeira cara do site do CMI eram três cores e três colunas: uma preta, uma vermelha e outra preta. Já era por causa de Seattle, por causa da liberdade, e do movimento ecológico. Já tinha essa idéia de unir os movimentos na própria organização estética do site. Era o nosso discurso, mas acho eu - que ele era usado de fato pelo movimento antiglobalização. Que de certa maneira era a convergência, e de certa maneira não era, porque tinha um grupo de pessoas ali que só se dedicavam ao movimento antiglobalização. 


\section{Mas isso foi mudando durante o tempo?}

Foi mudando, porque quando esse movimento antiglobalização desapareceu, as pessoas se voltaram para os outros locais e aí o CMI assumiu o papel de tentar fazer, do ponto de vista da comunicação, e não do ponto de vista prático - como era a nossa plataforma no ano 2000 - essa convergência. Só que, na minha opinião, com pouco sucesso.

\section{Até que ano você continuou atuando?}

Eu não saí oficialmente do CMI, pois continuo na lista do CMI São Paulo. Estou bem afastado, mas estou na lista, acompanhando.

\section{E o que você percebeu de mudanças, ao longo do tempo?}

Primeiro: o CMI é um projeto anacrônico, a meu ver, e tanto do ponto de vista social quanto do ponto de vista tecnológico. Porque quando nós nos propúnhamos a fazer a convergência dos movimentos sociais, esse pessoal estava convergindo praticamente com as suas limitações. Eles estavam já reunidos e estavam tendo fóruns de articulação política contra o processo de liberalização econômica. Essa convergência prática não existe mais. Do ponto de vista da comunicação é um projeto, digamos, informativo e não é um projeto político mais.

Mas o site do CMI é o único onde você vai ter, por exemplo, a luta pelo direitos animais ao lado das lutas pela causas gays ou étnicas. Não existe nenhum outro site onde essas duas coisas tenham a mesma dignidade. Mas essa convergência é uma convergência informativa. É um lugar onde você vai ver essas informações sobre tudo isso, e com dignidade. Mas esses movimentos estão convergindo, praticamente? Não! Esse projeto político faliu. E faliu quando o movimento antiglobalização, que é uma outra história, se dissolveu. Mas isso é outra coisa. Quando ele deixou de existir, esse projeto político prático desapareceu. Ele se transformou em um projeto informativo, por isso eu disse que eu acho ele anacrônico.

Então você não via o CMI, originalmente, como um projeto de mídia? Era uma coisa maior, e o que ficou foi só a parte de mídia?

Ele nasceu como um projeto de mídia, aquilo que eu e contei da época da Ciranda, com uma formação independente, só que ele tinha uma outra cara. A de um veículo de auto-representação do movimento. E no fundo, com essa ambição de que o 
movimento era o movimento dos movimentos, de auto-representação da sociedade na sua contestação. Então, o lugar em que você vai ver todos os movimentos se autoexpressando e se auto-comunicando. Essa era a nossa ambição política. Era um projeto de comunicação que estava articulado com um projeto político realmente. Essa circunstância prática desapareceu. Por isso fica com aquele status muito forte de projeto anacrônico: porque a circunstância prática do movimento desapareceu. Também porque ele é anacrônico do ponto de vista tecnológico. Nós fizemos uma verdadeira revolução, mas não só em fazer publicação aberta. A grande contribuição do ponto de vista da história da informação foi ligar a publicação aberta com a ideia de uma coluna editorial. O CMI já nasceu com aquelas duas colunas: do lado direito publicação aberta, qualquer pessoa publica; e na coluna do meio, a parte editorial. Mas a nossa política sempre foi: vamos construir o editorial não só nós, que fazemos o site, as pessoas vão publicar na coluna da direita e a gente pega esse conteúdo da coluna da direita e o organiza, como um editorial.

\section{Mas isso não acontece atualmente?}

Não sei dizer se está acontecendo ou não, mas essa é a ideia que estava por trás desde o começo. E acho que essa foi a grande inovação do CMI: fazer jornalismo a partir da auto-representação das pessoas. Que é uma ideia banalizada hoje com blogs, e com o chamado "jornalismo cidadão". Mas, na época, não existia nada disso.

\section{O fato de estar banalizado, ou amplamente difundido deixa a coisa} anacrônica?

Tecnologicamente anacrônico. No momento em que não havia nada disso, a gente era a plataforma tecnológica que podia realizar essa missão.

\section{Que valores você vê ainda no CMI, então?}

O CMI tem um certo histórico e uma baita visibilidade. Não tenho dúvida de que ele é o maior site de notícias de esquerda na internet, e de longe - a não ser que você considere "Carta Capital" de esquerda. Não tem mais ninguém, nem do ponto de vista do número de acessos, que chegue perto do CMI. Ele tem muita visibilidade, e é um site histórico da internet, que cumpre ainda o papel de dar visibilidade a essa autopublicação. Agora, ele não tem a mesma centralidade que tinha no momento original. Porque os movimentos arrumaram outros meios de auto-expressão. 


\section{O que seria necessário, na sua opinião?}

O CMI precisa se reinventar. Eu e vários companheiros do CMI estamos falando há muito tempo que ele precisa ser reinventar. A gente tem que falar que o CMI foi vítima do seu próprio sucesso, na minha avaliação. Porque o CMI, quando nasceu, teve um milhão de acessos. Imagina: foi uma coisa extraordinária, e a gente adotou aquele modelo, e tem seguido, sem mudanças no conceito, desde 1999. Já se passaram 10 anos.

Quais são as maiores diferenças, ou pelo menos quais eram quando você atuava mais fortemente, entre o CMI Brasil e os de outros países?

O coletivo do Brasil sempre foi um dos coletivos mais organizados do mundo, na minha opinião. E ele sempre teve boa comunicação com os movimentos sociais, coisa que a maioria dos outros não têm, com exceções, como o da Argentina, por exemplo. Mas eu não sei, eu acho que o CMI Brasil, tirando algumas características mais acentuadas do que outras, é um coletivo CMI típico.

\section{E em relação à orientação política?}

Tem CMIs que são mais anarquistas, tem CMIs que são mais, sei lá, profissionais. Tem uns que são mais autonomistas, outros são mais um gueto.

\section{E o CMI Brasil, você classifica como?}

Eu acho que ele é mais anarquista/autonomista. Embora não devesse ser. Isso é uma grande briga que a gente teve dentro do CMI, porque penso que ele deveria perder essa marca. Essa é a minha posição, mas as pessoas acham que não. Eu sempre fui a favor de que ele fosse apartidário, e não anti-partidário. Ou seja, dentro do CMI ninguém tem partido e ninguém atua em nome do partido. Então os caras com uma camiseta do PT, andando ali como um militante do PT, ou mesmo de uma maneira dissimulada, por mim tudo bem. Mas tinha gente que achava que militante de partido não tinha lugar lá. Eu achava que se entrássemos só nesse campo autonomista ele ia se "guetizar", como de fato, durante muitos anos, ele se "guetizou". O CMI foi realmente ganhar importância no Brasil depois de uns dois ou três anos já de existência. Ele era muito pequeno. Era um publicando para o outro, a gente tinha 300 acessos diários, era pequeno. Ele ganhou essa dimensão nacional bem depois. 
Em que medida você acha que o CMI, como rede de mídia, alcançou, alcançou parcialmente ou não alcançou os objetivos propostos?

Os objetivos originais? Eu acho que ele cumpriu a sua função por um tempo. $\mathrm{O}$ site do CMI colocar lado a lado para o leitor o movimento gay, a causa dos direitos dos animais e a luta sindical, sendo um lugar onde tudo é igualmente importante, cumpre um papel, mas não é o papel que tinha antes, no início. Naquela época a gente estava tentando fazer isso praticamente, fazer com que esses movimentos cooperassem para a construção de uma alternativa ao processo de liberalização econômica. Agora não, agora é, digamos, a difusão de todas essas causas.

\section{Você vê o CMI como um movimento social também?}

A gente não era um movimento, a gente era um grupo. Um grupo que estava ligado a um movimento social, que era o movimento antiglobalização. Hoje, embora ele tenha contato com outros movimentos sociais - em alguns casos, bem próximo ele não é um movimento social. É aquele grupo de pessoas que você está vendo. Basicamente se encontram com esses movimentos, apóiam esses movimentos, mas, praticamente, não são um movimento. O movimento tem que ser uma coisa de massa, de maior expressão. Tem que ter um objetivo político comum. Se você pensar, os organizadores do grupo são umas 150 pessoas. Elas não fazem um movimento. E se você pensar nas pessoas que usam o site, aquelas milhares, elas também não fazem um movimento porque não são pessoas organizadas buscando um objetivo político comum.

\section{Como você definiria o perfil dos organizadores do CMI Brasil?}

Originalmente eram jovens urbanos, ligados ao movimento antiglobalização, de orientação autonomista/anarquista. Esse perfil era o perfil de quem fazia o CMI e acho que ainda é. Uma coisa importante: isso nunca foi feito por gente com reflexão sobre comunicação. A gente tem uma anedota que ilustra bem isso. Fizemos um encontro da rede CMI Brasil, não me lembro o ano, no Rio de Janeiro, e eram dois dias de discussão. Um dia para gente discutir sobre a organização do CMI, sobre gestão, horizontalidade, decisão por consenso. E outro para falar sobre comunicação, profissionalismo, imparcialidade, neutralidade, perfil de fonte, questões jornalísticas e de comunicação que estavam relacionadas à produção do CMI. No primeiro dia, foi 
um dos maiores debates que eu já participei na minha vida, com pessoas muito abertas, com muita clareza, e experiência de organização horizontal. Foi um debate maravilhoso, cheio de gente, 100 pessoas debatendo de uma maneira madura e extremamente produtiva. No dia seguinte, tinha 15 ou 20 pessoas, e falaram 3 pessoas. Aquele silêncio... As pessoas não têm reflexão sobre comunicação. Sempre foi um fato que, para elas, aquilo era uma organização política. Porque quando acabou o movimento antiglobalização, começou ter gente que era militante do CMI e ponto. $\mathrm{Na}$ época, todo mundo era do movimento antiglobalização e do CMI, e depois teve uma geração de gente que não viveu o movimento antiglobalização e que achava muito legal o que tinha acontecido, tinha até uma visão meio mítica, heróica daqueles anos, e o CMI era uma espécie de herdeiro disso para eles. Então elas ficavam ali do mesmo jeito.

Você acha que isso seria uma deficiência do jornalismo que continua no jornalismo cidadão, a falta de reflexão? Isto é, só a prática, sem a reflexão...

Não sei avaliar esse tipo de experiência.

Dentro do próprio CMI, partindo-se do pressuposto que o CMI tem alguma característica que o aproxima do jornalismo cidadão.

Ele tem sim essa característica. Curiosamente, ele foi apagado da história... Pode ler aí em qualquer história sobre jornalismo cidadão: o CMI desaparece. Falam do Slashdot, por exemplo, que é um site importante ainda de tecnologia. Mas mesmo em número de acessos, ele é uma formiguinha perto do CMI.

Ele foi apagado da história, por um lado, por preconceito de quem escreve a história. Porque o CMI era uma experiência radical. E por outro, pelo próprio sectarismo do CMI. Pessoas super radicais e sectárias, muitas vezes não vão em encontros acadêmicos, têm resistência a se comunicar com as pessoas que estão escrevendo essa história, e a se colocar, falar: "não, fomos nós que começamos". Eu acho que o CMI nunca soube se impor, nesses termos. Ele sempre foi muito sectário, muito avesso à universidade. Enfim, perdeu seu lugar. Perdeu, efetivamente. E conheço mais ou menos essa literatura porque é minha área de estudo, e vejo que ele não está nesse histórico. Ele vai desaparecer da história de uma maneira extremamente injusta, porque o CMI é uma coisa muito importante. 


\section{Com que tema você trabalha nos seus estudos?}

Com a propriedade intelectual. Dou aula na EACH/USP, na disciplina de teoria política. Mas a minha pesquisa não é sobre teoria política, e sim sobre propriedade intelectual. O objeto é a propriedade intelectual e o seu conflito com a liberdade de informação.

\section{De alguma maneira tem alguma coisa a ver com sua atuação no CMI, não?}

Tem a ver no sentido que de o CMI tem licença livre, mas assim, eu não vejo a aproximação acadêmica com a militância. Não há nenhum vínculo direto. E o CMI é um projeto muito mais amplo que isso. Tem a ver com as discussões sobre comunicação e a supressão da figura do jornalista, questões relativas à qualidade, e que para mim sempre foram importantes. Eu sempre pedi isso também no CMI. Para mim, o CMI, por ser um projeto antiprofissional, deveria ter qualidade superior à profissional. A gente até dizia: o jornalista é profissional. Ele é restrito, porque está subordinado a um editor, a uma relação hierárquica, e ele está produzindo industrialmente. Ele tem que vender jornal, e isso constrange um pouco a notícia, o limita, porque ele está falando de alguma coisa que ele não sabe, ele não participa do movimento. Então a gente tem que fazer muito melhor, com excelência.

\section{Excelência em que parte?}

Nossa cobertura de qualquer coisa tem que ser infinitamente melhor que a do profissional. Infinitamente melhor. Nós não temos chefe, não temos rabo preso com ninguém, fazemos com nosso tempo. Não são as entrevistas de 15 minutos por telefone que o jornalista profissional faz sobre um assunto com o qual ele nem está envolvido. Se a nossa cobertura não conseguir ser melhor do que a dele, tem alguma coisa errada.

Se você sabe escrever, jornalismo se torna uma banalidade. Você responder as sete perguntas, montar um lead... isso é uma banalidade. Se você que é alfabetizado e participa do movimento não faz melhor que um jornalista profissional, tem alguma coisa errada aí.

Algumas pessoas criticavam essa postura minha e de outros dizendo: "estão querendo profissionalizar o CMI". Isso é uma coisa que me irrita, eu sempre achei que a gente deveria buscar essa excelência. Eu sempre achei que a pessoa do CMI vai saber muito melhor... Se o MST ocupou um terreno em Taboão e um integrante do 
CMI não estiver melhor informado que um jornalista... E te digo: a gente sempre estava melhor informado, mas a única coisa que estava melhor representada no CMI era o ponto de vista.

As pessoas não se interessavam e nem sabiam deixar de uma maneira clara o que aconteceu, separar fato de opinião. Verificar, checar. Coisa banal, pegar um telefone. O CMI não faz. Nunca se levou isso a sério. Ou então não ligavam porque tinham vergonha de ligar. Enfim, e é um veículo com 30 mil acessos por dia, o que dá um milhão de acessos por mês. Não é um "sitezinho da esquina".

A impressão que eu tinha é de que iria encontrar no CMI mais pessoas da área de comunicação trabalhando de uma maneira diferente do que elas trabalham eventualmente no emprego delas. Você acha que a presença maior de jornalistas, ou de pessoas com afinidade com estas práticas teria ajudado nisso?

A gente teve um monte de jornalista. Nunca foram a maioria, mas a gente sempre teve.

\section{Então a minha pergunta já esta respondida: não adianta.}

Não, não adianta. Não precisaria ser uma coisa muito sofisticada. E isso mesmo é uma prova de que o profissionalismo pode ser superado. Por exemplo, falando de outras limitações. Essas discussões de comunicação nunca avançaram. $\mathrm{O}$ pessoal do CMI não tem interesse na comunicação. Vou te dizer coisas que aconteceram. Eu sempre achei - e coloco em primeira pessoa, mas outras pessoas também achavam -, por exemplo, que a gente deveria, ao contrário dos últimos grandes periódicos, fazer uso de fontes primárias.

Por quê? Porque a gente está lidando com um veículo na internet, a gente trabalha basicamente com a internet. A gente tinha a possibilidade, nas nossas matérias, de simplesmente linkar para a decisão de um juiz, porque era uma decisão pública, e incorporar aquela decisão do juiz de maneira a emancipar o nosso leitor da mediação jornalística que era a nossa tarefa primeira. Poderia se fazer isso em massa, para tudo, linkando a fonte primária. A gente tem multimídia. Linka a entrevista em MP3, linka a entrevista em vídeo, linka a decisão do juiz, linka a lei. Isso funcionaria como um elemento fundamental na compreensão da história. De maneira que nosso leitor não precisasse daquele resumo do jornalista, que frequentemente vem distorcido porque ele não entende do que está falando. Mas a gente não fez isso. E não fez 
porque? Porque não tinha discussões sobre linguagem, sobre internet, a função do jornalista. Em todas nossas discussões era sempre um grupo pequeno de pessoas que estava preocupado com a comunicação.

\section{Miryám Hess}

A ativista Miryám Hess, que prontamente se disponibilizou a conceder esta entrevista, é uma voluntária de personalidade marcante dentro do grupo do CMI que acompanhamos em São Paulo. Além de sua postura bastante combativa, demonstrada por suas falas e seu histórico como ativista, trata-se de uma personagem multifacetada: uma judia que defende tanto o respeito a seus pares de ascendência quanto aos povos árabes; que se apresenta com tendências políticas "anarco-punk", como afirma, mas prefere adotar um visual inspirado nos nossos indígenas; que trabalha oito horas por dia como geóloga numa repartição pública, mas encontra tempo e disposição para militar pelos direitos humanos de etnias das quais não faz parte. Que com mestrado concluído e doutorado em vista, afirma morar na favela e criar galinhas - não para comer sua carne, pois é vegetariana.

Afora estes aspectos pessoais, ressaltamos suas ações no intuito de trazer mais destaque no CMI para a temática do movimento indígena brasileiro, do qual participa, e sua crítica a como a grande mídia trata a questão. Também se destaca o seu relato da atuação da Rede Indymedia por ocasião do acirramento do conflito entre judeus e palestinos, e de como neste caso, segundo ela, a tecnologia da comunicação bem empregada contribuiu para salvar vidas.

Miryám faz ainda um interessante paralelo entre a concentração de terras no país e a dos meios de comunicação: o latifúndio da terra, que começou com a Lei de Terras de 1850, e o latifúndio das mídias, expresso no regime de concessões de rádio e TV e na posse por alguns grupos restritos dos maiores meios de comunicação impressos.

\section{Qual sua profissão Miryám?}

Sou funcionária pública. Trabalho como geóloga, especialista em desenvolvimento urbano, aqui na Subprefeitura do Butantã. 


\section{Quais são suas áreas de atuação principais nos movimentos sociais?}

Eu atuo em direitos humanos e em questões étnico-raciais há mais de 20 anos, sou Promotora Legal Popular e atuo mais dedicada nas lutas indígenas, através da Rede GRUMIN de Mulheres Indígenas ${ }^{22}$, e nas lutas camponesas, apoiando a Via Campesina e o MST.

\section{Que tipo de ações você faz nestes grupos?}

No GRUMIN eu faço representações que vão para a Presidência da República, para o Ministério Público. Muitas das petições e documentos sou eu que redijo. Por ser Promotora Legal Popular e ter contato com a parte de direitos humanos, tenho algum conhecimento jurídico que me permite isso. Participo de eventos e conferências representando o movimento indígena, e também aciono as autoridades, repassando denúncias de graves violações de direitos humanos, não apenas de indígenas, mas de outros grupos.

\section{Como você conheceu o CMI e começou sua participação?}

É engraçado que eu não me lembro de como eu conheci o CMI, mas me lembro muito bem de 2001, de quando eu já estava lá dentro do coletivo, da gente atuando em conjunto, eu e um árabe. Foi um trabalho muito sério, de ir ao front de guerra e conseguir salvar vidas, da maneira mais rudimentar possível.

Tenho duas fases no CMI. A primeira foi esta em que eu entrei e atuei muito na questão da guerra, lá no Oriente Médio e a gente conseguia realmente salvar vidas. Foi um trabalho muito importante porque, enquanto o Estado de Israel bloqueava toda a imprensa e até mesmo a imprensa alternativa, nós conseguíamos ter acesso a informações através da forma mais humilde possível: a vítima se comunicava em árabe com o CMI Jerusalém, lá era traduzido para o inglês e do inglês para os demais idiomas. Em duas horas tínhamos aqui no Brasil em português o que a vítima havia declarado por celular em árabe. Então, neste período de duas horas, tínhamos aqui notícias que eram segredo de Estado. Com isso, a gente conseguia ter um movimento de ação em defesa da população civil que salvou muitas vidas - não todas que gostaríamos, mas foi um trabalho seríssimo este de ir ao front de guerra e fazer uma mídia alternativa.

\footnotetext{
${ }^{22}$ Site: http://www.grumin.org.br. Aceso em 20/08/2008.
} 
Fiquei afastada do CMI por seis anos e voltei recentemente pela ocasião de um ato no Ibama onde encontrei um voluntário do CMI. Então retomei o contato e acabei voltando. Na verdade, eu já estava com este projeto de retornar porque precisamos de canais alternativos para divulgar as lutas indígenas. A mídia pilantra mente muito sobre a questão indígena, incitando ódio contra os povos indígenas, racismo, xenofobia. Dá versões totalmente distorcidas. Na imensidão dos latifúndios, as milícias oficiais e as dos latifundiários se confundem; existem muitos indígenas trabalhando em situação de escravidão nos latifúndios, existem torturas contra as pessoas camponesas. E na grande imprensa, os paramilitares que estão estuprando e torturando passam como pessoas de bem, e indígenas passam como criminosos.

No movimento indígena, temos uma rede em que as lideranças das próprias comunidades vítimas entram em contato por telefone, ou por email, quando sabem escrever em português e têm acesso aos equipamentos. Então isto vai para a lista de contatos do movimento indígena e entramos com representações, acionamos o Ministério Público, e sempre que possível divulgamos também no Exterior. Estou pleiteando também um espaço específico no Centro de Mídia Independente para a cobertura das questões indígenas, porque as violações de direitos humanos estão cada vez mais graves com o avanço do neoliberalismo.

Em uma palestra do [José] Arbex [Jr.] na USP, ele estava ridicularizando o fato de o governo Bush chamar os índios de terroristas. No intervalo o chamei de lado e disse: Arbex, não ria não, porque a coisa é séria. Eles sentem mesmo os indígenas como ameaça. Se você parar para pensar, o modo de vida indígena é sim uma alternativa ao modo de vida no sistema capitalista. E eles têm uma luta anticapitalista muito consistente, desde Chiapas - e veio depois Oaxaca, para mostrar que eu não estava mentindo.

Você se lembra de um exemplo de matéria com estes problemas que você apontou anteriormente?

Temos vários, você pega, por exemplo, toda a cobertura sobre a questão de Raposa Serra do Sol, que você vê claramente. Foi comentado até no Observatório da Imprensa. Inventam que os arrozeiros estavam lá há muito tempo, sendo que, na verdade, esta já era uma terra indígena demarcada. Tivemos um ato com a participação do jurista Dalmo de Abreu Dalari e da Dra. Deborah Duprat em que foram listadas as mentiras ditas no caso Raposa Serra do Sol, em defesa dos 
arrozeiros, que na verdade poluem, degradam o meio ambiente, ameaçam os indígenas, os atacam e queimam as malocas - e nada disso a grande imprensa mostra. Na revista Veja só se encontram matérias dando a versão dos arrozeiros. A verdade não costuma ser expressa na grande mídia, o que fez com que as lideranças da terra indígena Raposa Serra do Sol fossem ao Exterior, clamando por auxílio da União Européia e da ONU. Então, no Indymedia, temos que fazer este contraponto.

Outro exemplo é a cobertura feita pela grande mídia sobre o Santuário dos Pajés, na qual índios foram chamados de "ex-índios"- coisa que não existe. O próprio Governo de Brasília acusa-os de grileiros de terras, de oportunistas, invasores de terras públicas. Todavia, aquelas são terras indígenas ancestrais, onde se supõe que as escavações arqueológicas possam dar indícios mais seguros do Peyabiru, caminho que ligava o Atlântico ao Pacífico nas rotas pré-colombianas. No Indymedia, vemos os indígenas em vários vídeos fazendo rituais. São povos que, como costumo lembrar, estão em situação de genocídio cultural e físico há 515 anos aqui no continente (AbyáYala).

Além de atuar no GRUMIN, costumo trazer estas problemáticas para o CMI, avisando sobre situações graves de que fico sabendo, levando pautas para a lista do CMI, escrevendo textos. Não faço parte do coletivo editorial, apesar de ter interesse em fazer. Quando escrevo, publico na coluna da direita, como qualquer pessoa que entra lá.

\section{Por que você não participa do coletivo editorial?}

$\mathrm{Na}$ verdade eu não tenho acesso direto, e quando quero mandar alguma pauta para os editoriais eu passo para outro voluntário, que tem acesso a esta lista, e fico aguardando o aval. Quando eu voltei para o CMI, fui entendida como uma pessoa nova, pois boa parte dos que me conheciam de 2001, que eram do meu tempo, não estavam mais lá, estavam envolvidos em outras atividades. A lista editorial não é aberta diretamente para todos, é preciso um tempo para ser aceito/a.

\section{Você acha que mesmo dentro da mídia alternativa há uma concentração} maior em alguns temas do que em outros?

Sim. O coletivo aqui de São Paulo, por exemplo, é formado por uma equipe muito pequena e que trabalha mais a questão de moradia. Quando eu cheguei, ninguém tinha muita familiaridade com a questão indígena. Tinha apenas uma pessoa 
que dava notícias nesta área e eu comecei a dar outras mais amplas e o pessoal achou legal. Eles não tinham contato nem com as lideranças da cidade de São Paulo de Piratininga, como a cacique Jandira e os caciques Timóteo Verá e Popyguá.

\section{Como você entrou em contato com esta temática, isto é, o que te despertou}

\section{para a questão indígena?}

Foi da maneira mais dramática possível. Quando eu era criança, eu era vizinha de uma índia que era daquelas vítimas de genocídio pelo próprio Estado Brasileiro, que catava pessoas a laço. Elas eram laçadas como gado, retiradas da sua comunidade e trazidas à força para a cidade. Na época ela tinha cerca de 75 anos de idade e eu cinco. Em Santo Amaro, onde eu morava, todos tinham uma série de restrições a ela; não queriam que nos aproximássemos dela, coisas assim. Ela era alcoólatra pela violência que sofreu e era tratada como louca. Eu sou uma testemunha viva que pode dar este depoimento: conheci uma das vítimas indígenas que foi caçada a laço.

Acho interessante que durante muitos anos eu me esqueci dela, pois ela morreu quando eu era muito pequena. Então, na época em que eu estava fazendo meu mestrado, lá pelo terceiro ano, eu me lembrei claramente daquela figura olhando para mim, eu como criança. Aos catorze anos me marcou também uma ocasião em que um europeu virou para mim e perguntou se índio era gente. Eu virei para ele e perguntei se ele era gente, e ele não me respondeu, e morreu sem responder.

Além da questão indígena eu sempre chamo atenção para a situação das questões negra, cigana, árabe, e judaica, que são muito graves também. Até hoje ciganos, judeus, negros são mortos por causa da sua condição étnica, então não é dizer que não é uma situação grave. Mas considero a situação indígena ainda mais grave, pois se chega ao ponto de se questionar se índios são humanos até hoje. E não estou brincando, não. Lembro-me de uma matéria antiga que li, e na época fiquei tão chocada que joguei o jornal fora. Hoje vejo que deveria ter guardado. Era um genocida de indígenas que dizia que, quando ele promovia seus assassinatos, "as fêmeas choravam e se grudavam nas crias como se fossem gente".

O CMI congrega vários movimentos e temáticas. Você apóia todas elas ou tem restrições a alguma?

Eu sou originária de dois movimentos: o de direitos humanos e o ambientalista. Fiz parte do Greenpeace e de outras ONGs ambientais. Só que eu saí do 
movimento ambientalista porque, em geral, os/as participantes são muito despolitizados/as. Então se colocam a falar contra pessoas pobres em geral, sobretudo acusando os indígenas de cometerem crimes ambientais - e daí meu "racha" com o movimento ambientalista de foco eurocêntrico/etnocêntrico. Você tem que saber exatamente quem degrada o meio ambiente e, ao contrário do que se pensa, os ricos degradam muito mais do que os pobres.

No meu mestrado ${ }^{23}$ no Instituto de Eletrotécnica e Energia da USP, discorri justamente sobre isto. A Unesco e outras entidades estão ensinando uma coisa errada por aí, que é atrelar o índice de qualidade de vida (IDH) ao alto consumo de energia per capita, que é a quantidade de energia gasta pelas pessoas. E o que pesquiso é uma inversão disto: quanto mais se gasta energia, menor é a qualidade de vida, por conta do estresse, da poluição, entre outros danos graves à saúde. Até mesmo a iluminação que utilizamos é excessiva, e isso estressa o organismo. Na época, foi uma coisa bem polêmica levar a Escola de Frankfurt e o questionamento do "desenvolvimento" e da "neutralidade da ciência" para a discussão acadêmica na USP, no âmbito da Poli. Na minha pesquisa eu questiono: "Desenvolvimento para quem, cara pálida?"

Então, voltando, eu não aceito este discurso de alguns ambientalistas de que os indígenas destroem o meio ambiente. Ainda discuto as questões ambientais, mas desde que elas sejam embasadas em parâmetros de biogeoquímica que determinam a sustentabilidade ambiental. Quando começa um discurso truncado de que "índio é problema para parque", eu paro e digo: "Não. Desculpe, mas o parque é que é problema para índio, porque os parques são demarcados em terras indígenas”. Existe, em geral a sobreposição das terras indígenas em áreas ambientalmente preservadas, e os indígenas sempre perdem nos tombamentos ambientais de uso restrito.

Você citou alguns grupos com posturas bem radicais. No âmbito dos movimentos sociais você também encontra pessoas com estas posições muito dogmáticas?

Sim, encontramos bastante. No Brasil, há um ódio muito grande contra a cultura judaica. Este ódio veio dos portugueses e é fortíssimo. Até dois anos atrás você ouvia falar "morte aos judeus!" na avenida Paulista, na República do Líbano, na porta da Hebraica. Eu mesma cheguei a passar por uma tentativa de estrangulamento por ser

${ }^{23}$ Rondani, 2002. 
judia, numa manifestação pela paz no Oriente Médio. Um indivíduo, que acha que a solução para paz no Oriente Médio é matar judeus, começou a por em prática isso lá na Praça da Sé, naquela ocasião. Como a judia que estava exposta era eu, fui o primeiro alvo. E nada aconteceu com ele, não foi preso, não aconteceu absolutamente nada com o agressor.

No próprio CMI, por causa da liberdade para publicar e da permissão de anonimato, estamos com um problema que é a presença de nazistas que estão usando o site como parque de diversões para a publicação de conteúdos racistas.

Em outra ocasião, eu usava uma camiseta com a bandeira de Israel junto da bandeira da Palestina, e discutia sobre assuntos do Oriente Médio na Rua da Consolação, na quadra da CIP, com uma amiga de ascendência judia, quando um nazista chegou e me empurrou com um golpe de ombro que me fez dobrar a coluna, e eu quase bati a cabeça na guia. Por pouco não estaria aqui hoje conversando com você [risos].

\section{Com essas experiências que teve, você pensou algum momento em se afastar} do ativismo?

Machuca né, você fica combalida. Eu sofri reações de antissemitismo no grupo anterior do CMI. Não era todo o grupo nem era a maioria, mas eu fiquei muito machucada e saí. O brasileiro tem esse problema de, quando lida com a questão do Oriente Médio, colocar o árabe como "coitadinho" e o judeu como "monstrinho" - e não é assim. Tem radicais dos dois lados, baixarias como morte de crianças, dos dois lados. Se você fosse uma judia morando num kibutz, sem fazer mal para ninguém, e esfaqueassem e matassem seus filhos e você, daria para perguntar: será que todos os árabes são tão bonzinhos assim? Ou então o pessoal que não tem conhecimento e defende, sem saber, os califados, a alta burguesia - que o próprio povo árabe fala: “pelo amor de Allah, não defendam nossos opressores!” Existe terrorismo dos dois lados, e mesmo que o terrorismo de Estado seja muito mais condenável do que o de grupos e indivíduos, e que a população palestina seja muito mais atingida, não dá para dizer que a população civil de nenhum dos lados tenha que conviver com o terrorismo, seja ele de Estado, grupos ou pessoas.

Teve um fato hilário que aconteceu naquele debate sobre a questão do Oriente Médio no Sintusp. A Federação Israelita Paulista, que ia, na última hora não quis comparecer. A Direção do Sintusp, que me conhece, me chamou para falar na mesa, e 
fui enquanto comunidade judaica. A minha fala foi uma fala de tentativa de conciliação, num local onde estavam presentes membros dos partidos como PSTU, além da Federação Árabe Palestina, e do próprio Sintusp. Havia pessoas que apoiavam um levante das massas árabes para exterminar seis milhões de judeus israelenses! E mesmo assim consegui fazer uma fala conciliatória, levando a problemática indígena, negra, pedindo para o pessoal, por exemplo, olhar a questão da Colômbia, que não é menos grave do que a dos territórios ocupados, para as pessoas sendo exterminadas pela etnia em vários locais. Isto ocorre em todo o Planeta: no Tibet, no Timor Leste, e por aí vai. Sem polarizar o discurso, ou tratar os territórios palestinos como único caso do Planeta. Consegui a vitória de, não defendo a destruição de Israel, não ser vaiada. Embora, para deixar explícito, em longo prazo eu defenda a "destruição" de todos os Estados. Mas, no presente, por que destruir só Israel? Isto é anti-semitismo - por que os brasileiros ficam querendo destruir um Estado que está em outro continente e não se movem para "destruir" o Estado Brasileiro também? Coloquei estas questões na mesa, e eu, judia, no término do debate estava sendo abraçada por um libanês - em plena guerra do Líbano! - o que para mim é uma vitória.

\section{O que mais te realiza nestes trabalhos?}

Eu sou uma pessoa voltada para as políticas públicas, e é no ativismo que posso desenvolver isto. Estudei durante 16 anos em universidades públicas, gratuitas, financiadas pela sociedade e almejo devolver para a sociedade esta riqueza que me foi propiciada. É o que eu tento, inclusive, no mestrado.

\section{Nos meios institucionais você acha que isto não é possível?}

A gente, como funcionária pública não tem espaço. No meu caso, tenho que ficar "de boca fechada", não posso falar nada em nome da Subprefeitura. Isto não tem nada a ver com este ou aquele partido, trata-se da norma da Empresa e está atrelada ao Estatuto do Funcionário Público, que é da época da ditadura militar e está em vigor, com pequenas alterações, até os dias de hoje.

\section{Eles sabem da sua ligação com os movimentos?}

Sim, até porque eu tenho que avisar algumas vezes quando vou a algum evento, em que participe Governo e Sociedade Civil, para deixar evidente que não 
estou falando em nome do Governo, mas em nome de uma das organizações que participo.

Com seus colegas de trabalho, você conversa sobre estes temas?

Não... Geralmente não rola [risos].

\section{Politicamente você se define como?}

Eu sou anarquista, com uma certa tendência anarco-punk, só que eu não adoto o visual americanizado de alguns punks que usam coisas muito sintéticas e industrializadas. Eu assumo um visual indígena, enquanto anarquismo mesmo. São ações afirmativas que despertam a identidade indígena nas pessoas que olham os adereços indígenas que eu uso. De certo modo, a roupa que você usa é sua segunda pele, e você coloca sua ideologia política nela. Pensando assim, a forma como eu me visto é, em si, uma ação anticapitalista.

\section{Você tem religião?}

Eu sou Xamã. Participei também de religiões Afro, mas como no Candomblé eu teria que sacrificar animais - e isso não faço - para dar continuidade, então acabei saindo.

\section{Reparei que tem bastante gente vegetariana no CMI. Você é?}

Carne eu não como de jeito nenhum, mas sem ser vegana, pois como derivados de leite e ovos das galinhas que crio. Mas lá tem bastante gente vegana, sim.

\section{E há preconceito com quem come carne?}

Olha, se tem eu não sei - eu nunca vi. É tudo normal. O máximo que aconteceu foi eu levar uns pães de queijo para o pessoal comer porque não sabia, e alguns não quererem, pois tinha queijo e os veganos não comem.

Queria te perguntar da relação da tecnologia com a comunicação nos movimentos sociais. Você acha que as coisas estão mais fáceis agora, como os relatos que você fez das comunicações por celular, por email, etc?

Faz muita diferença, como nos casos que relatei, do uso do celular pelas vítimas do bombardeio, impedidas de se comunicar pelo Estado de Israel. A 
tecnologia na mão de povos em situação de genocídio físico e cultural pode ser usada como socorro, e para fazer denúncias de violações graves de direitos humanos.

\section{Você vê a internet como um divisor de águas na articulação destes grupos?}

Olha, vou te dizer que a gente sempre deu um jeito enquanto imprensa alternativa. Lembro de um jornal levado pela ECA, pelo pessoal do Oboré ${ }^{24}$ e o Serjão [Sergio Gomes], que era afixado na USP, cada número de uma cor para verem que não era o mesmo. Eles tinham estratégias de se encontrar, em plena ditadura militar, arriscando a vida. Se você pega a Inconfidência Mineira, por exemplo, também tinham ações na imprensa clandestina. Se você for até a África, você tem os tambores rufando e anunciando os inimigos; e, em Abya-Yala, tinha os sinais de fumaça. Então a humanidade sempre dá um jeito de se comunicar. Mas a internet ajuda bastante sim. Quando o Arafat foi preso, por exemplo, foi pelo site do CMI que fiquei sabendo que não estavam dando um remédio que ele precisava tomar todo dia. Então eu fiz uma carta enviada por email para várias embaixadas, inclusive a de Israel, dizendo que se o paciente (Arafat) tivesse a medicação cortada ele poderia morrer e quem seria responsável pela morte de Arafat seria o Estado de Israel. Sei que logo depois voltaram a dar o remédio a ele - não tenho como provar que foi em razão da divulgação da notícia e destes emails que enviamos, mas o Arafat não ficou mais sem a medicação.

E dentro da crítica da mídia tradicional, não alternativa, você vê algum caminho possível?

Há vários. Existem articulações muito interessantes, como o Observatório da Imprensa. E há outros caminhos de atuação, a exemplo do que vem sendo trilhado pelo Intervozes, Oboré e o Portal Gens ${ }^{25}$.

Mas, no meu entender, é preciso ir mais além do que a simples reforma do sistema de "latifúndio das mídias", com suas concessões de rádio e TV vencidas e que continuam nas mãos dos mesmos. A partir da Lei de Terras (1850), legaliza-se o latifúndio da terra. E assim começa o "latifúndio da grande mídia", que passa a pertencer aos mesmos donos dos latifúndios da terra, criando uma retroalimentação de poderes econômicos, sociais e midiáticos. Então, a questão fundiária se desdobra, até

\footnotetext{
${ }^{24}$ Site http://www.obore.com. Acesso em 20/08/2008.

${ }^{25}$ Site http://www.portalgens.com.br. Acesso em 20/08/2008.
} 
porque muitos dos donos das redes de mídia são também latifundiários e políticos, e isso se perpetua desde 1850 até os dias atuais, este é o cenário político que explica, por exemplo, a atuação do Congresso Nacional e o estranho comportamento do Ministério das Comunicações.

Outro fator que devemos levar em conta é que a Lei de Terras (1850) inviabilizou o processo de libertação de indígenas (1590) e afrodescendentes (1888). Isto ocorre porque a libertação de uma pessoa escrava requer, necessariamente, o acesso à terra para agricultura de subsistência. Por isto, nós que lidamos com as questões étnico-raciais afirmamos que se encontra inconcluso o processo de libertação de indígenas, desde 1590, e afrodescendentes, desde 1888. Logo, não há como desatrelar a Lei de Terras do racismo institucional, e de toda injustiça social que dele emana. Então, são três tipos de "reforma agrária" que defendo: da terra, das mídias e do saber dentro das universidades, porque todos eles, no caso do Brasil, caracterizamse pelo eurocentrismo e pelo etnocentrismo.

\section{Quais são seus planos para o futuro?}

No CMI eu pretendo que a presença indígena seja mais forte, que tenhamos um espaço dedicado à causa indígena. E estou preparando meu projeto de doutorado em Antropologia.

\section{Flecha}

Boa parte dos voluntários do CMI prefere adotar um codinome para sua identificação. A segurança pessoal é a justificativa. Estudante de Geografia, o voluntário conhecido como Flecha afirma se interessar por atuação política desde que participava do movimento estudantil secundarista, ainda em Manaus, onde morava. Ao ter contato com o CMI, vindo para São Paulo, conheceu diversos outros movimentos sociais, e essa variedade de lutas foi um dos pontos que mais o interessou na proposta do coletivo, além estrutura não hierárquica que permitia sua expressão em condições de igualdade com qualquer outro voluntário. Flecha explicou detalhadamente como funcionam os processos decisórios, por consenso, tanto de propostas de mudanças técnicas quanto na produção de conteúdo para os editoriais da coluna central - as dificuldades sendo sobrepostas pela vantagens desde tipo de estrutura. Ressaltou a importância do veículo como divulgador das temáticas dos movimentos sociais para pessoas que as desconhecem, relatando sua atuação como 
fotógrafo e destacando o aumento na liberdade de expressão propiciada pela internet, quando comparada a outras mídias (TV, jornal) de produção mais custosa e mais regulada pelo Estado.

Flecha também relembrou algumas ocasiões de maior satisfação pelo trabalho desenvolvido, seja pela divulgação das imagens que produziu, seja pela interação tanto com os próprios colegas do CMI quanto com as pessoas envolvidas nos diversos movimentos sociais.

\section{Primeiro eu gostaria que você contasse como começou seu envolvimento com o CMI.}

$\mathrm{Eu}$ comecei frequentando sites de notícias alternativas de manifestação. Eu morava em Manaus e já gostava de manifestação, já era ligado nessas coisas políticas. Aí me ligaram uma vez falando que estava passando uma cobertura de uma manifestação na "Buzina do Cazé", lá da MTV, e eu vi que era um grupo CMI que estava organizando. Então eu fui atrás do site e comecei a visitá-lo. Foi aí que eu conheci o site Mídia Independente. Com o tempo eu fui analisando a estrutura, como o site funcionava, a participação. Então um voluntário, que estava passando por Manaus, fez um encontro comigo e com uma garota que estava interessada em formar um coletivo em Manaus.

\section{E vocês entraram em contato por email?}

Foi, na primeira vez eu entrei em uma lista de discussão e falei que eu estava com interesse de participar do CMI. Eles falaram que era para eu ler uns textos de formação de novos voluntários. Só que quando aquele voluntário foi para Manaus, eu já estava com a mudança programada para São Paulo. Quando eu cheguei em São Paulo, mandei email perguntando onde é que aconteciam as reuniões, e então eu comecei a frequentá-las.

Nesta época você já estava aqui em São Paulo. Você chegou a frequentar reuniões lá em Manaus?

Lá nós fizemos uma, só que depois a outra garota se desinteressou por formar o coletivo e aí eu mudei pra cá e abandonei o de lá. 


\section{O que mais te chamou atenção no CMI?}

$\mathrm{O}$ que muito me chamou atenção foram as pautas, as notícias, porque eu sempre fui muito mais ligado ao movimento estudantil. E quando eu conheci o CMI em 2005, o pessoal aqui em São Paulo estava mais engajado no lance de moradia, de habitação. Então para mim, que nunca participei de nada relacionado a esses assuntos, chamavam a atenção essas pautas alternativas de políticas públicas referentes a habitação e moradia. E eu lá, distante dessa realidade, achei interessante e comecei a frequentar.

Você acredita que conheceu outros movimentos sociais além do movimento estudantil por conta deste contato?

Com certeza. Várias formações que eu tive foram no decorrer dessa história. Quando eu comecei a me interessar por política, comecei pelo movimento estudantil, então não sabia direito o que era DCE, não sabia dos movimentos dos partidos dentro dessa estrutura do movimento estudantil. Foi no tempos finais em que eu estava em Manaus que eu fui descobrindo isso, a ligação dos partidos com o movimento estudantil. O que me chamou muita atenção quando eu entrei no coletivo de São Paulo foi essa não-ligação direta que se tem com os partidos. Lógico, tem essa possibilidade de ser de algum partido, mas o CMI não assume nenhum específico, e tem uma restrição a assumir alguma linha partidária.

O CMI não assume, mas se tiver algum voluntário que faça parte da algum partido, independentemente, não tem problema?

Exato. Inclusive tinha, no passado, um garoto do PSOL que frequentava direto as reuniões. Ele era um associado voluntário.

Eu queria que você falasse mais coisas que o agradam no CMI e, se houver, algumas coisas que, a seu ver, precisam mudar, melhorar.

Mais coisas que me agradam no CMI? Ah, eu acho que essa estrutura, que para mim era novidade, essa estrutura da anarquia. Por exemplo, eu entrava, e tinha um voluntário, que era professor já, o Pablo, eu ali estudante secundarista e ele discutindo comigo no mesmo patamar hierárquico. A gente na mesma posição política de pautas e discussões do CMI. Isso foi para mim uma novidade muito agradável. E as pessoas ficaram como um grupo de amizades, até mesmo para além do CMI. 


\section{Houve afinidade...}

Total. E acho que ajudou bastante também; isso ajuda muito na interação. Você acordar às vezes 10 horas da manhã, às vezes de madrugada com os caras, e poxa, vai conversando e ficando amigo da pessoa. Já teve casos de a gente dormir cinco voluntários no carro esperando uma ocupação do MST. Então ficam cinco pessoas juntas, a noite inteira, a madrugada inteira, acaba tendo um relacionamento mais próximo com essas pessoas. E agora, mudanças?

\section{Algo como "não é bem por aí", em que seria legal ter alguma modificação.}

Então, de mudança, que eu acho que cai na mesma posição, é esse lance pessoal dos voluntários. Para mim foi bom porque eu não tive nenhum problema pessoal com nenhum voluntário, mas isso às vezes se torna um problema. A gente está pensando ainda uma forma de resolver essas situações, quando intrigas pessoais transcendem essa parte pessoal e se tornam uma briga maior, no coletivo.

Quando você está fazendo um trabalho voluntário que não te obriga a fazer nada, vai muito da sua disponibilidade de tempo, da sua disposição, e isso às vezes causa algum atrito se alguém que topou fazer alguma coisa não faz. E aí entra naquele campo da cobrança. Mas isso ocorreu há um tempo atrás, agora não está mais ocorrendo.

É lógico que a rede em si tem problemas, mas eu teria que pensar. Agora eu não saberia citar um problema. São coisas pontuais que quando ocorre a gente fala: "nossa, isso é um problema que a gente tem que realmente conversar sobre”. Só que, como há esse distanciamento - a internet não substitui tudo - então falta um convívio com a pessoa, porque às vezes você manda um email na melhor das intenções, e é interpretado de uma outra forma, e que se tivesse dito pessoalmente não ocorreria esse tipo de atrito.

Em relação ao que estava sendo comentado em uma reunião, de um certo esvaziamento dos voluntários. Como você vê isso? Vocês estavam falando que são como ondas.

Ah, eu vejo como uma coisa não específica do CMI, como um esvaziamento geral do interesse atual das pessoas em política, em atividades extra-obrigatórias. Acho que você nota isso em movimentos sociais, no CMI, em atividades de movimento estudantil. 
Não é que esteja esvaziando aqui e indo pra outro lugar, não é?

Não, acho que é mais uma coisa geral que não sei se é que não se está conseguindo mobilizar, ou se é um tipo de desinteresse. Eu ainda não consegui, pessoalmente, detectar o que é exatamente, mas tenho quase certeza de que não é um problema específico do CMI.

Você falou das divergências. Acha que o fato de o CMI congregar movimentos bem diversos é um dos motivos para isso se aprofundar?

Não. Eu acho que isso não é o motivador dos problemas. Acho que é realmente uma questão de divergências, às vezes políticas, às vezes pessoais que se misturam, o que é normal. Cada um tem um jeito de trabalhar e o de aceitar o trabalho do outro, entende? De repente eu não me incomodo se alguém me cobra, tem gente que se incomoda com qualquer cobrança. Então as pessoas são diferentes e essa forma de você lidar diferente é o que às vezes dificulta o trabalho. Principalmente nessas questões políticas como o CMI, ou em organizações políticas, onde a sensibilidade da pessoa fica mais aguçada, as características ficam mais fortes, e então ela se ofende.

Você acha que o perfil da pessoa que é voluntária no movimento social seria também parte disso?

Pode ser também. Acho que isso também conta. É o jeito de você trabalhar. Se você trabalha em uma empresa, a empresa tem aquele jeito que tem que trabalhar. Já o CMI não tem aquele jeito que você "tem" que trabalhar, então cada um faz de um jeito diferente, e isso às vezes dificulta um pouco, trabalhar-se com uma diversidade muito grande. Na maioria dos casos tem dado certo, mas é lógico que ocorrem problemas. Atualmente, como a gente falou anteriormente, há uma falta de entrada de voluntários, e se tenta ao máximo evitar a saída de antigos. Então, quando se tem uma entrada de voluntários, é o caso de lidar melhor com a situação. Sabe, "sangues novos", que não participam dessas divergências, entram participando, mediando mesmo os dois lados. É uma das vantagens da estrutura que eu falei, da horizontalidade. 
E em relação às ideias do CMI que as pessoas que entram e não conhecem ainda? Pode ser que a pessoa chegue com um comportamento inadequado, e tenha que ser dialogado com ela como é que funcionam as coisas ali, por exemplo. Isso é tranquilo?

Nunca tivemos nenhum problema de a pessoa já entrar tumultuando. Porque normalmente, quando a pessoa entra, ela está interessada no projeto, está interessada em participar, só que ela não conhece a estrutura interna do CMI. Quando você vai numa reunião, é muito diferente do que você vê no site. A primeira atitude da pessoa não é ela tomar uma frente já logo de cara e querer opinar. Normalmente, as pessoas que entram são novas, elas ficam mais retraídas por não entenderem direito. Como são várias pessoas, de vários movimentos sociais, várias tendências, então é uma complexidade muito grande. Mesmo que a pessoa já tenha uma experiência de movimento social.

Até pegando o exemplo do Movimento do Passe Livre, que tem uma estrutura parecida com a do CMI. Já teve voluntário que participou do MPL e entrou no CMI e teve essa postura de primeiro ficar retraído para saber como é que é, quem são as pessoas, se conhece alguma, se conhece todas. E a gente tenta trabalhar assim, agregar essa pessoa o quanto antes para ela participar. Então quando alguém entra, normalmente a gente tenta colocar um voluntário mais antigo sentado do lado da pessoa para poder, em uma conversa paralela, se a pessoa não entendeu algum artigo, alguma coisa, ou algo da própria reunião, parar e perguntar: "não sei o que é esse assunto de que estão tratando, não estou sabendo a pauta", e aí explicar com a maior paciência possível.

Vocês têm problemas com, por exemplo, a pessoa chegar lá e já querer se destacar, achar que ela não tem que fazer nenhum outro trabalho, só vai escrever $e$ que vai sair no editorial?

Não. Dentro do CMI você estabelece, mais ou menos, a sua atuação. É lógico, cada um tem suas preferências. A mim agrada mais trabalhar com foto do que escrever texto. Então ficou meio que definido que o Flecha seria o fotógrafo. Não sou fotógrafo oficial, nem profissional, mas é o que me agrada mais. Tem gente lá que vai na reunião e fica um tempão em lista de tradução. Só gosta de fazer tradução, não quer saber de outra coisa. A pessoa começou a frequentar as reuniões, não gostou das reuniões, mas continua no CMI na lista de tradução. Porque ela não se interessa muito 
por essa discussão mais prática, e gosta só da parte de tradução. Ou se interessa pelo projeto, mas a disponibilidade de tempo dela é somente para a parte de tradução.

A impressão que eu tinha, quando eu conheci o CMI, é que nas reuniões se discutia sobre o que ia ser o conteúdo do site. Mas há várias outras coisas sendo discutidas, e por isso eu lhe fiz essa pergunta. As pessoas chegam lá geralmente com uma idéia errada? Vêem que tem muita coisa pra fazer, e às vezes coisas trabalhosas e que nem são bacanas de fazer, mas precisam ser feitas, e às vezes se desinteressam?

É, normalmente as pessoas têm uma ideia errada. É lógico que tem pessoas assim com menos dedicação, mas elas não participam diretamente do CMI. São pessoas que visitam frequentemente o site, escrevem muita coisa - não tanto na coluna editorial, por uma falta de interesse, ou por uma falta de conhecimento da possibilidade de escrever para a editorial - mas são pessoas que estão direto no site, escrevendo artigos e postando conteúdos sem participar de fato do coletivo.

Falando sobre a coluna da direita, tem muita gente que escreve coisas lá que não estão dentro da política editorial ou que são textos meramente opinativos. Seria uma preguiça das pessoas em se informarem? - porque existe no site um link com as informações sobre o CMI. Ou você acha que tem alguma coisa a mais aí atrapalhando as pessoas de saberem o que é o CMI de verdade. Não sei se é só uma opinião pessoal, nem sei se está certa, mas eu vejo muita gente que tem uma visão equivocada do que é o CMI.

Não sei, cada visão é um caso diferente. Teve gente que falou que achou o site complicado, eu quando entrei não achei complicado. Inteirei-me rápido sobre o que era o CMI e sua proposta. Mas já me falaram que o visual do site é complicado, e tem gente que não tem realmente interesse em saber mais do site. Pesquisou alguma matéria no Google, achou o site, entrou na página principal e viu lá que podia publicar alguma coisa, sabe? E nem conhece a linha editorial.

No momento a gente está, no coletivo editorial, com propostas para melhorar a filtragem. A gente recebe muita publicação, então temos que tentar melhorar a qualidade dessas informações. Realmente tem muita informação que não seria o caso de estarem lá. Estamos com uma proposta aprovada, e só falta a implementação técnica. Ainda não está totalmente definido como vai ser isso, se vão ser só os 
administradores e o pessoal da lista editorial que irão moderar, ou se a gente vai abrir uma forma de cadastro dos usuários, e aí todo mundo que visita o site vai poder escolher as melhores matérias, que estão com uma qualidade boa, mais enquadradas na política editorial, para terem um destaque no site, uma diferenciação. É a chamada publicação promovida, que já é uma política usada em outros CMI pelo mundo.

\section{E as pessoas que fazem parte do coletivo editorial, quais são os critérios para} uma pessoa entrar nele?

A gente teve milhares de discussões sobre hierarquia, confiança e segurança. Já entendemos que realmente as informações com que a gente lida devem ter um sigilo maior, não por uma questão hierárquica, mas por uma questão de segurança da própria rede, para a rede se manter. Esse mês, por exemplo, já teve servidor apreendido lá no Reino Unido. Então acho que se não houvesse essa segurança, o CMI já não existiria, e já teria problemas piores. A segurança passa por uma restrição de informação. E aí você decidir quem que tem a permissão de acessar esta informação ou não. Eu diria que a maneira mais correta de fazer isso de uma forma que tente seguir ao máximo possível a horizontalidade é o coletivo editorial. É um processo de confiança, o qual quem está há mais tempo, ou quem está mais por dentro do CMI já entende. Então não está restrito a uma pauta, não está restrito a uma tendência só. A pessoa deve ter uma visão mais ampla da situação local, um pouco nacional - porque também uma pessoa saber tudo é difícil -, mas ter um enfoque maior para poder mediar essas situações de um artigo que diz respeito a Recife, por exemplo. Às vezes chega um artigo de Recife, e você está por dentro do que está acontecendo lá, ou então você tem que saber quem está, você tem que ter os contatos de quem está lá e peguntar: "Isso está certo, o grupo é legal mesmo, é assim mesmo que está no artigo?" Para checar a credibilidade do artigo.

\section{E tem aquele esquema dos três “OK”, não é?}

Tudo no site é na base do consenso, só que no inicio do processo a gente teve que estabelecer quando que o consenso é atingido ou não. Por exemplo, um artigo que foi publicado, e um voluntário jogou no "lixo aberto". Tem que ser consenso o artigo ficar no lixo aberto, se não for consenso o artigo permanece no site, entendeu? Se não for consenso, o artigo não vai ficar no escondido, vai ficar no lugar certo para todo mundo ver, exposto no site. E a mesma coisa com o editorial, mas com o editorial é 
muito mais rápido, porque já tem esse processo de confiança de que eu falei anteriormente. Normalmente, quem escreve para a coluna dos editoriais são os próprios voluntários que conhecem mais a política editorial. Já conhecem melhor a proposta do CMI, então escrevem uns editoriais mais propícios e por isso que é muito raro ter algum editorial que não vai paro o ar. Por exemplo, no caso do meu primeiro editorial quando eu entrei no coletivo São Paulo, eu ainda não fazia parte da lista editorial, e eu fui fazer uma cobertura de uma manifestação antiguerra do PSTU e depois de um grupo anarquista. Lembro que eu tirei as fotos e fiz uma proposta editorial, e eu era voluntário novo, não na lista editorial. A proposta foi barrada, mas por critérios de política. Não lembro exatamente qual foi o motivo, mas foi por não estar dentro dessa adequação à proposta CMI. Lembro que esse é um exemplo de como é importante que a pessoa faça parte do coletivo há algum tempo para entrar na lista editorial. Então foi um processo assim, em que eu fiquei até um pouco decepcionado por não ter sido aceito, mas hoje eu entendo que foi certíssimo, porque é questão de conhecer a estrutura, a política. Depois de um tempo eu até dei uma lida na proposta que eu fiz e disse: "nossa, se fosse hoje eu não teria feito assim. Se eu pudesse, deletava isto da lista no histórico" [risos]. Você chega e não entende direito como funciona, por isso que tem que ter essa confiança.

Pelo o que você está me relatando, os processos editoriais funcionam bem, certo? E a gente vê, tem uma atualização até rápida. Mas e em relação a outros processos do CMI, como funciona esse consenso? Porque eu imagino que tem coisas que são grandes, que têm que envolver diversos coletivos. Você vê uma demora em chegar a consensos para implementar outros processos?

Com certeza. A dificuldade do consenso consiste em duas frentes: a primeira é ter o consenso da diversidade. É você conseguir fazer uma proposta sua, perante a diversidade de toda uma rede, então acho que aí já é uma dificuldade com que você vai trabalhando na discussão. Em segundo fica a questão tempo. $\mathrm{O}$ consenso não é uma coisa rápida: quando precisa de algum consenso nacional, você dá 15 dias, um mês, e, a depender da proposta, até mais para os coletivos locais terem tempo hábil de discutirem nas suas reuniões. Cada coletivo local tem a sua periodicidade de reunião "x"; alguns fazem uma reunião por semana, outros a cada 15 dias, ou uma vez por mês. 
Não dá pra passar por cima, assim, não é?

Não, dependendo da proposta você estabelece uma data, um limite de uns 15 a 30 dias. Se for uma proposta muito importante para a rede, você dá um tempo maior, para um maior número de pessoas discutir.

\section{Dê um exemplo de proposta que foi feita nesse esquema.}

Um exemplo de proposta é essa da publicação promovida, feita por um voluntário para a rede nacional. Aí a gente deixou 30 dias para os coletivos discutirem, mas ocorreu de algum coletivo não ter tido tempo. Chegou a discutir, estava em ata que eles começaram a discussão, mas não tiveram tempo de terminar. Então a gente estendeu o prazo para o coletivo decidir se era a favor ou não. E, lógico, nesse meio tempo, o coletivo gerou dúvidas em sua reunião, que foram enviadas para a rede e discutidas.

As discussões acontecem dentro de cada coletivo, e depois entre os coletivos?

Sim, exatamente. Se algum coletivo não concorda, ele terá que colocar o motivo de não concordar e aí trazer uma contra-proposta. Não que a contra-proposta seja obrigatória, mas é que o bom senso leva a dizer a quem bloqueou deve colocar alguma contra-proposta, alguma sugestão de alteração, e aí ela entra na discussão.

Chega um momento em que não tem consenso, mas tem a maioria. Isso é válido também?

Não.

\section{A democracia...}

Não, aí a proposta é indiretamente arquivada e deixada para ser discutida em uma reunião nacional, pessoalmente.

E isso para tudo? Por exemplo: para um editorial entrar no ar, tem que ter os três "OK" de pessoas da lista editorial, e isso é atingido. Mas alguém que já é do coletivo editorial vai e fala assim: "Não, acho que isso não pode entrar de jeito nenhum desse jeito”. Então, mesmo que tenha os três “OK”, não entra?

A pessoa tira o editorial do ar e manda email falando que não concorda por algum motivo, e aí isso vai ser discutido. Como o editorial em muitos casos trata de 
notícias com um tempo de validade, às vezes vale a pena uma discussão em cima dele, e às vezes não. Se é um editorial de algum fato, algum evento, por exemplo. No caso da inauguração do espaço Ay Carmela! ${ }^{26}$, a gente colocou o editorial e divulgou o evento. E isso gerou uma discussão na lista da necessidade de divulgar eventos locais em editoriais. A gente colocou um editorial, mas eu nem sei se agora o editorial está no ar ou não. Acho que ele ficou por um tempo, e até é uma proposta que eu ainda não fiz, mas em que vou pensar melhor depois: editoriais temporários. Mas enfim, gerouse esse questionamento na lista editorial da necessidade de fazer um editorial chamando para eventos. Mas aí tem o seguinte: como você trabalha com consenso, e você sabe que consenso é difícil, às vezes você questiona aquela necessidade, aquela pauta, mas você acaba aceitando ali no momento para não travar o processo. Então a pessoa que questionou...

\section{Não está $100 \%$ satisfeita, mas aceita.}

Exatamente. Porque você sabe que é difícil, lógico. É uma questão muito da pessoa. Então é por isso que não dá pra você colocar como administrador do site na lista de editorial qualquer voluntário que apareça, entendeu?

Entendi. Para não aparecer um “casquinha de ferida” lá que implique com tudo e atravanque os processos.

Exatamente. Você tem que saber se a pessoa tem esse bom senso, e a noção da dificuldade de trabalhar com consenso. Muitas vezes o consenso é você abdicar temporariamente daquela sua posição para discutir depois em um momento mais adequado. Então você guarda uma discussão para uma reunião nacional. Aí o que acontece? Aquele editorial em particular permanece, mas dali para diante não se faz mais editorial daquela forma. Isso de trabalhar com maioria não existe no CMI.

Conte agora um dia ou um acontecimento que marcou você dentro do CMI.

\section{Pode ser positiva ou negativamente.}

Não tem um específico que me marcou mais, são vários acontecimentos que vão ocorrendo, vão marcando e vão dando uma satisfação cada vez maior. De insatisfação são raros. É um trabalho, é um trabalho voluntário, e é lógico que às vezes

\footnotetext{
${ }^{26}$ Ver 15
} 
tem algumas pressões, você fica um pouco cansado do fluxo de emails, ou está em um momento pessoal difícil e isso acaba refletindo um pouco na sua atividade no CMI. "Putz, não aguento mais a discussão", sabe? Você fica de saco cheio. Mas não lembro de um específico, assim. Agora, de satisfação são vários. Eu tenho uma imensa satisfação de tirar uma foto para o CMI e depois ver essa foto circulando. Por exemplo, de uma manifestação. Outro dia eu estava andando aqui pela PUC e vi uma foto que eu tirei de uma manifestação num cartaz. Aí eu falei: “nossa!”.

\section{Não estava nem assinada?}

Não, tinha os créditos de CMI, porque eu tiro às vezes fotos como "CMI-São Paulo" e às vezes como "Flecha", então tinha lá o crédito, mas assim, sabe, isso aí, o crédito... A partir do momento que você está fazendo um trabalho voluntário, o crédito é só para ter uma fonte de onde você tirou aquilo, só para indicar para as pessoas que não conhecem.

\section{Em situações como essa você vê o resultado, não é?}

Exatamente. Estou ali, andando, e vejo a foto, é claro que foi muito bom.

\section{Você sabe que foi para frente.}

Isso. Ou quando você vai em alguma ocupação, e aí o pessoal te recebe super bem, te oferece um café da manhã - não têm nem onde morar e dizem: "não, não, toma aquii", e você: "não, não quero", e aí: “não, toma aqui, por favor, não vai fazer essa desfeita, toma um leitinho" [risos]. Você acaba interagindo e isso eu acho demais, são essas as satisfações e as gratificações.

Como que você vê o trabalho dos movimentos sociais, que ao que parece, na maioria das vezes não mostra um resultado imediato. Você às vezes se incomoda com o ritmo como as coisas andam?

Eu vejo isso assim, que realmente a atividade que você faz pode gerar um resultado diferente. Não atinge aquele objetivo que você queria, mas tem um outro resultado muito bom, positivo. Um caso, por exemplo, foi a ocupação da reitoria da USP. Foi um trabalho muito bom que o CMI fez. Uma cobertura, e não só a cobertura: a gente conseguiu interagir com essa ocupação e ajudar o pessoal. Eles não permitiam que nenhum veículo de comunicação fizesse contato, e o CMI eles não consideravam 
um veículo de comunicação grande contra a ocupação, assim pudemos realizar matérias lá. E a gente concordou com as premissas da ocupação, de não tirar foto lá dentro, e fazer filmagens sim, mas mantendo a privacidade das pessoas. Isso no CMI a gente já conhece. Se você vai numa reunião, deve ter o consenso do grupo ali que está fazendo a reunião para você levar um gravador e fazer a gravação, ou tirar uma foto, filmar. Então acho que de resultados assim, você tem variados, diferentes resultados para diversas ocasiões. Às vezes positivos, e às vezes, lógico que não é aquilo que você esperava. Eu vejo a função do CMI como um divulgador de atividades. Como a ocupação do Edifício Mercúrio, o CMI trabalha como um divulgador do que ocorreu. É um registro do que ocorreu no Mercúrio. Aquilo não é registrado pelos grandes veículos de comunicação.

\section{Só o fato de você estar registrando e divulgando é importante...}

Isso, são outros objetivos, diferentes dos do movimento em si, porque é lógico, o CMI quer que o pessoal tenha habitação, moradia, e apóia isso, mas na forma de um divulgador. O objetivo do CMI é mais o de fazer com que aquele assunto se torne uma pauta de discussão entre os movimentos sociais ou entre as pessoas que frequentem o site. Eu acho que isso é super válido, até porque, como você vê, o perfil do usuário que acessa o CMI é muito variado. Eu estava fazendo cursinho esses dias e uma garota falou que entrava no CMI para ver as notícias da época dos ataques do PCC. E ela não participa de movimento social, não é ligada a política, não se interessa por isso, mas frequentava, começou a frequentar o CMI. Então, essa é uma maneira de você trazer essas pessoas que às vezes não conhecem essas atividades - assim como eu lá no início -, de trazer essa pauta para a pessoa, para ela questionar e se inteirar do assunto, do que está acontecendo. E às vezes essas pessoas se interessam e vão trabalhar com o movimento. Tanto que tem muita gente que entra no CMI e depois começa a militar em outros movimentos, paralelamente ao CMI. Então isso já é um apoio aos movimentos, já é um fruto da divulgação, que é uma das funções guia.

\section{Seria uma frente de comunicação dos movimentos?}

Sim, seria uma frente de comunicação dos movimentos sociais, mas a nossa intenção não é que sejam os voluntários essa frente, a intenção é que os movimentos utilizem o CMI para fazer a sua divulgação. Não é ser necessário ter um voluntário lá 
do CMI tirando foto, mas que tenha alguém do próprio movimento com câmera lá, tirando foto, e tenha essa possibilidade de publicar no CMI depois.

Sim, eu estava reparando que é difícil encontrar pessoas que são "só do CMI”. Geralmente a pessoa está em pelo menos mais um movimento.

Isso que causa a diversidade do CMI. Porque cada um atua paralelamente em um movimento social diferente, e aí traz sua pauta para o CMI.

Qual é a sua opinião sobre a mídia praticada de maneira geral no Brasil? Como você vê essa mídia?

Como que eu vejo a mídia nacional? Eu acho que ela está fazendo parte do jogo político e econômico que ocorre no Brasil. Do mesmo jeito que você tem dentro da política algumas pessoas interessadas em fazer coisas boas, coisas legais para a sociedade, e outras que não vêem isso como uma prioridade e querem se promover e buscar seus próprios interesses. Acho que a mídia reflete esse jogo político e o jogo econômico. Enfim, acho que está atrelado, e não só por parte dos veículos de comunicação, como também dos reguladores, como a Anatel.

Mas, fora do CMI, é possível praticar uma mídia alternativa? Existem alternativas?

Sim, acho que é possível. O CMI é só um exemplo. Quando eu conheci o CMI, eu entrava também em um outro site, que não existe mais. Eu era mais voltado para movimento anarco-punk, mas frequentava os dois. Lembro de ouvir críticas sobre o CMI nesse outro site. Só que achei os assuntos que aquele site abordava muito restritos ao movimento anarco-punk, e tem aquelas fichas já demarcadas, aqueles tópicos. Mas penso que era válido aquele site, era uma outra forma de fazer notícia, uma outra forma de você divulgar as suas atividades. Citando um outro exemplo, tem um jornal que um garoto faz em que escreve só sobre o Oriente Médio. Ele mandou um email para o CMI, em 2006, e a gente fez contato, aí ele começou a publicar no CMI. Então gerou essa união de mídias alternativas, e foi bastante válido.

De uma maneira mais genérica, qual a importância do jornalismo para você?

Nossa, profunda, hein? [risos] Qual a importância do jornalismo? 
Você está trabalhando e não é jornalista profissional, mas de qualquer maneira você é um foto-jornalista, então isso deve significar alguma coisa para você, em termos de "por que eu estou fazendo isso?", "por que eu acho que a comunicação é importante?".

Sim, essa troca de informação que a internet possibilita, sabe? Eu estando aqui em São Paulo e cobrir uma manifestação e informar, ou então fotografar como que foi a manifestação para quem, por motivos geográficos ou outros, não pôde estar ali. Eu mesmo, morando em Manaus, achava muito importante essa cobertura de eventos, atos, manifestações.

\section{Você acha que as pessoas precisam ter acesso, então?}

Sim, eu não conhecia tanto os movimentos locais, então para mim era essencial ter contato com os movimentos daqui, ver que tinha gente mobilizada. Se não, você olha ao redor e vê que só tem você, e isso o desmotiva um pouco a fazer as coisas. Mas quando você tem um veículo que demonstra que você não está sozinho, que tem um monte de gente fazendo uma correria em outros lugares, você fala: "nossa, eu quero trazer isso para cá”. Que foi o que aconteceu lá em Manaus. Eu falei: "nossa, eu quero trazer o CMI para cá".

Então acho que a importância do jornalismo para os movimentos é essa. Não você ser o "rei da informação", mas poder demonstrar globalmente o que está acontecendo ao seu redor. Demonstrar que o pessoal está na atividade, não está parado. Acho que isso motiva coisas em outros lugares. E no caso da internet, é uma forma viável de a gente fazer isso, já que eu acredito que perderam um pouco do controle da internet. Se a gente tivesse essa possibilidade, talvez o CMI tivesse um canal de televisão, por exemplo.

Mas aí é como eu falei anteriormente, de estar tudo sob controle, tudo nesse jogo já estabelecido, e você não tem essa possibilidade. Um jornal é muito mais caro, e muito mais difícil as pessoas terem acesso a um jornal. Por isso também que o CMI deu certo, porque ele é um veículo de comunicação cibernético. Lógico que não dá pra você pensar "Ah, então está certo, estamos bem, vamos manter o site só". Não, eu acho que o site é o primeiro passo, e aí você se encaminha para outros meios, o áudio, o impresso, o vídeo. 
Essa era uma das minhas perguntas com relação à tecnologia. Você acha então que a internet facilitou bastante a comunicação dos movimentos sociais?

Sim, eu acho que facilitou muito. Ainda pode facilitar mais, porque não é o todo movimento social que tem dinheiro para comprar uma câmera e nem tem interesse de comprar uma câmera para ficar divulgando na internet. Mas eu acho sim que a internet se tornou uma forma de você poder se expressar. Agora estão tentando limitar isso com leis, o "Projeto Azeredo" no Brasil e as leis internacionais que limitam essa possibilidade de você poder se expressar. Mas, por enquanto, acho que ainda está dando. E enquanto der, o CMI se manterá no ar. Penso que o CMI se fortaleceu exatamente por isso, por ter explorado essa forma nova de mídia. Agora não é novidade, todo mundo já faz um vídeo, coloca lá no Youtube, ou já tem uma troca de informação pela Wikipedia, que é muito grande, o Google já dominou a informação na internet, então eu acho que hoje tudo ficou muito mais claro para a sociedade. Mas veja, o CMI surgiu em 1999, e sua a proposta já era uma diferença tremenda, uma mudança na forma de se comunicar. As pessoas em 99 usavam o quê? Usavam ICQ para se comunicar, e só. Entravam ali no site do UOL e tal, e aí surgiu o CMI como uma opção. E acho que isso deu certo e estamos aí até hoje por causa disso.

Que temas, dentro dos movimentos sociais, despertam mais sua atenção? Isto é, com que lutas você se identifica mais?

O que eu participo com um gosto maior pessoal é o movimento estudantil. Tenho um interesse maior pelo movimento estudantil, e lógico, depois acabo assumindo outras pautas que os outros colocam e que eu concordo. Não dá pra você participar de tudo e ser um super expert em tudo. Até porque tenho a minha vida pessoal também, tenho que estudar. Mas acabo tendo uma simpatia por todas as pautas que o CMI coloca. Não teve nenhuma pauta que eu falei: “essa aí não me agradou”. Eu, no início, por não conhecer, não tinha uma simpatia pelo movimento de habitação, de moradia, e acho que com o tempo eu fui me inteirando e, lógico, cada vez me interessando mais. Se o dia e a vida fossem mais longos, acho até que me envolveria mais com outras pautas também, com outras atividades. 
Você tem a impressão de que fazem todos parte de uma coisa só, esses diferentes movimentos? Eles não estariam ligados de alguma maneira?

Eu acho que de alguma maneira estão todos ligados sim, porque eles estão querendo quebrar com essa estrutura atual, desde o MST querendo quebrar o latifúndio, até o Software Livre querendo quebrar a estrutura da Microsoft, que era hegemônica, na internet, nos computadores. Então acho que sim, eles estão ligados nessa tentativa de mudança. Mas cada um trabalha de um jeito diferente. Se você vai conversar com o pessoal do Software Livre, todos são adeptos do software livre, mas nem sempre a pessoa que está apoiando o software livre apóia, por exemplo, um MST. Às vezes ela tem uma visão política diferente daquela que você imagina. Então acho que os projetos em si estão ligados, mas nem sempre tem essa interação de militância, de voluntários entre essas organizações e movimentos diferentes.

\section{Mas eles se respeitam, certo?}

Exatamente, eles se respeitam, mas há uma diferença muito grande entre eles. O MST apóia o Software Livre, tem esse link, mas nem todo mundo do Software Livre tem uma visão política mais profunda.

\section{Ou nem conhece o movimento direito.}

Isso. Acho que tem também as divergências no modo de trabalhar. $\mathrm{O}$ do Movimento do Passe Livre, por exemplo, é diferente do do CESP e do CEDISP, que estão lá na sede do MST, e que são organizações mais antigas, e com voluntários de outra faixa etária. Mas, estão juntos, e acho que se tivesse que juntar todo mundo daria certo. Se o mundo caminhasse para uma catástrofe global, acho que daria para todos esses movimentos se unirem sim, seria uma possibilidade.

O próprio CMI, por exemplo. A gente apóia o MST, mas tem discordâncias fortes com ele, políticas mesmo. Mas se o ocorre uma desocupação importante dentro do MST é lógico que a gente vai apoiar o MST. Mas não é um apoio cego, a gente questiona. Só que em um momento importante ali, sabe, é a mesma coisa do consenso. Às vezes você tem que, para não ficar travado, abdicar um pouco das suas discordâncias, e aí naquele momento você apóia, e depois você vai opinar. Então não é um apoio cego, mas você também não pode negar apoio. 


\section{Você, politicamente se define como anarquista? Ou você "não se define"?}

Eu não digo que eu sou um anarquista, mas tenho uma simpatia pela organização, pelas estruturas anti-hierárquicas. Para você se autodefinir anarquista, deve ter um embasamento teórico daquela política, e eu acho que ainda tenho pouco. Então não gosto de me definir como anarquista porque eu não tenho essa visão mais teórica.

\section{Isadora}

Envolvida de 2001 a 2008 nas atividades do CMI, a historiadora e pesquisadora Isadora relatou várias experiências de atuação no coletivo: cobertura, atos de protesto, produção de conteúdo, discussões e realização de oficinas de publicação aberta. Vê com um certo pessimismo a situação dos meios de comunicação, concentrados, apesar de acreditar, obviamente, na importância de iniciativas alternativas como o CMI. Assim como Flecha, valoriza bastante a maneira autogestionária em que os processos são conduzidos no CMI, ao que contrapõe as discussões pesadas, retóricas e hierárquicas do movimento estudantil ou de movimentos de esquerda tradicionais - mesmo que também tenha algumas críticas sobre alguns processos do CMI, em particular uma preocupação exagerada, em sua opinião, com segurança. Está atualmente afastada do ativismo direto, mas, pela facilidade prática, escreve em um blog, onde ainda expressa opiniões e repercute fatos relacionados aos movimentos com os quais têm mais afinidade, como o de minorias sexuais. Apesar disso, fala com certa nostalgia do período em que participava do coletivo, quando segundo ela, aprendeu muito sobre novas formas de se atuar com política e movimentos sociais

\section{Eu queria que você me contasse primeiro como começou o seu envolvimento} com o CMI. Há quanto tempo foi, como você conheceu?

Bom, eu entrei entre 2001 e 2002, bem no começo do CMI. Mas na verdade eu comecei a minha atuação política no movimento estudantil - na USP, no curso de História, logo quando entrei, em 1998. No movimento estudantil eu conheci outras pessoas que estavam articulando as questões do movimento que depois passou a ser chamado de antiglobalização aqui no Brasil. A primeira manifestação foi chamada de S26, ou 26 de setembro, e era contra o BID e a OMC. Depois de participar dessa manifestação comecei a participar mais ativamente da Ação Global dos Povos, que é 
uma rede de organizações e de grupos pelo mundo. E nas preparações para o A20, contra a ALCA, eu acabei já participando meio marginalmente do CMI. Na verdade eu ajudei, pois eu estava no lugar onde eles se encontravam, no ICAL, o Instituto de Cultura e Ação Libertária, e o pessoal estava fazendo uma edição do Ação Direta um jornal impresso do CMI - e eu sempre gostei de escrever, escrevia bem.

\section{Está falando do CMI na rua, o jornal-poste?}

Não, o Ação Direta era um outro jornal impresso, com formato tablóide, que tinha pequenos textos focados na questão da ALCA, e também algumas brincadeirinhas, como palavra-cruzada, alguma coisa assim, meio que brincando com esse formato jornal. E aí eles precisavam de alguém pra revisar textos, ou para formatar algumas coisas, e eu acabei fazendo e me interessando. Foi então que comecei a frequentar as reuniões do CMI.

Você ficou sabendo destas ações por meio de contatos no movimento estudantil?

Sim. Eu era bem antiga do movimento estudantil, onde também havia pessoas ligadas a esse lance de um movimento mais autonomista, mais antiglobalização. Peguei uma época do movimento estudantil lá no curso de História em que se falava muito da questão da autonomia, da autogestão, e então as coisas se cruzavam um pouco. De lá eu conheci pessoas que estavam no CMI e também se articulando com o movimento antiglobalização. Comecei a participar das primeiras reuniões, fazendo essa ponte. Eu continuei no CMI com períodos de afastamento, e voltando, com períodos menos ou mais ativos, até 2008, quando realmente saí de vez. Mas antes de sair eu fiquei um ano e meio ou dois anos ainda nas listas [de email], ajudando pontualmente.

\section{Quais eram as suas atividades até esse período?}

O meu período mais ativo foi até o meio do meu mestrado, 2005, no máximo. Eu fazia de tudo, menos vídeo porque nunca soube mexer com vídeo, e também não tinha muita paciência para aprender. Mas eu participava das reuniões, ajudava a administrar o site, e nas poucas situações de manifestação, de coisas mais ativas nesse sentido de luta pela democratização da mídia, eu participei também. Participei, e ajudei a organizar, por exemplo, o ato em que trocamos o nome da Avenida Roberto 
Marinho para Vladimir Herzog. E participava da administração do site, mas sempre gostei muito de fazer as coisas estando mais próxima dos movimentos sociais; então eu também participava muito do que chamávamos de cobertura. Algum evento importante, alguma movimentação que estivesse ocorrendo. Atuei bastante na cobertura da causa dos sem-teto.

Mesmo depois do movimento, entre aspas, "antiglobalização" - eu sempre falo entre aspas porque eu sou controversa em relação a essa denominação, mas enfim, só para ficar mais legível - eu participei também. Eventualmente fazia alguma tradução, entrava nas discussões das listas, ou fazia algum editorial. Fui para o Fórum Mundial Social com o pessoal do CMI, participei das atividades lá também.

Acho que eu tive uma participação bem espraiada por todos os âmbitos, não era muito dada à parte internacional, às listas e esse trabalho de ligação das discussões nacionais com as internacionais, nunca foi muito a minha praia. Fazia também oficina sobre publicação aberta e sobre o CMI em vários lugares. Essas eram as coisas que eu gostava de fazer, que eu achava legal, e em que poderia contribuir. Escrever matérias, fazer oficinas, divulgar as propostas do projeto, participar das reuniões - porque também é importante opinar.

Quando você fala de cobertura, é texto e foto, ou uma coisa mais concentrada que a outra?

Eu fazia texto e fotografia na mesma proporção. O texto dependia um pouco da urgência da coisa, e do tipo de informação que se queria passar. Então, muitas vezes, acabava publicando mais fotografia e textos menores também, porque muita coisa era urgente. Quando dava tempo, e mais na elaboração de editoriais, eu trabalhava com texto. Mas eu gostava muito de fotografar, sempre gostei, e nunca gostei muito de fazer entrevista. Mesmo rádio, essas coisas de mexer com áudio, porque as coisas técnicas não eram muito a minha praia, a não ser fotografar mesmo, e então eu ficava muito na parte de fotografar e escrever.

Em relação aos temas dentro dos movimentos sociais, com quais que você se identificava mais?

Por afinidade imediata e por proximidade, eu acabei cobrindo muita coisa de movimento feminista e LGBT. Porque eu tinha acesso, e quando a gente começou no movimento antiglobalização, eu e outras pessoas tentamos formar um grupo neste 
sentido, só que essa questão da sexualidade acabou não indo para frente. Mas eu sempre tentei discutir com outras pessoas a questão de gênero e de sexualidade dentro do movimento. Então, por afinidade e proximidade, eu acabava cobrindo muito esse tipo de assunto, era mais fácil, chegava mais informação, eu estava dentro das listas, tinha mais contanto com o movimento.

Fora isso, posteriormente, eu trabalhei muito com o tema das ocupações e movimento dos sem-teto - que era também uma coisa que me interessava muito, a própria questão da cidade. A questão da democratização da mídia, e do movimento antiglobalização, do exterior ou aqui do Brasil, eram também outros temas com que eu me envolvia bastante, pelo site. Questões relacionadas ao meio ambiente eu pouco me envolvia, mesmo que acabasse opinando em tudo.

\section{Que características do trabalho que é feito no CMI mais lhe agradavam, que} chamaram mais sua atenção quando resolveu participar?

A proposta do CMI era - e continua sendo - muito sedutora, no sentido de você poder fazer a sua própria versão. De certa maneira, isso que me atraiu, porque eu gostava de escrever - sempre gostei, sempre me expressei bem nessa forma - não é à toa que eu fiz graduação na área de Humanas e continuei na pós-graduação. E essa proposta me parecia uma possibilidade de usar essa ferramenta para algo para o bem coletivo, uma aplicação política.

\section{Quais eram os pontos fortes do CMI que você não via em outras ações do gênero?}

Às vezes fica até difícil separar o CMI do movimento antiglobalização em que eu estava, porque algumas discussões eram parecidas, e foi um momento de encantamento com as duas coisas ao mesmo tempo. Bom, eu sempre participei do movimento estudantil, mas eu nunca tinha estado em um grupo, em um movimento, em que tivesse tanto poder de falar. Que eu pudesse ser ouvida, e também me sentisse ouvida e com poder de participar e influenciar as decisões, então acho que isso era o que funcionava melhor.

\section{A que você atribui isso?}

Eu acho que o próprio espírito do movimento que estava se formando na época, no sentido de defender fortemente a horizontalidade e de que todo mundo 
soubesse o que isso significava. Outra coisa que pode ter influenciado nisso, que também me encantava não ter no CMI, e que era uma coisa bem do movimento estudantil, era a coisa da retórica e aquelas plenárias - e esse é um lado em que os homens dominam muito mais, a retórica e o discurso - enfim, tinham as plenárias em que havia aqueles discursos enormes sobre a conjuntura internacional e a esquerda. E no CMI não tinha isso, se fazia uma discussão política muito profunda, muito radical, mas muito menos fechada no sentido de ter que dominar uma retórica " $\mathrm{x}$ " muito bem para poder fazer sua voz ser ouvida. O CMI tinha gente que não tinha entrado na faculdade ainda, ou que não ia entrar e que não tinha essa perspectiva, ou gente que era das Exatas, a menina mais novinha, as pessoas mais velhas, então desde uma pessoa que estava fazendo doutorado, até alguém que estava no cursinho, ou até uma pessoa que não estava a fim de nada disso, que não estava a fim de cuidar dessa coisa mais acadêmica. E eu acho que isso também sempre foi saudável para o CMI e me fez me sentir mais em casa. Criou outro ambiente de atuação, e isso me fascinou bastante. Era isso, a coisa da transparência, da horizontalidade, de poder fazer as coisas. Era tudo muito prático, tinha um sentido, era tudo muito direto. A qualidade da discussão política era muito grande e eu aprendi muito com o CMI e o meu ativismo no movimento antiglobalização. São coisas que eu levo para a vida, e que eu usei em outros âmbitos também. Eu trabalhei no mestrado com antropologia da política, e aquele aprendizado de que as coisas podem ser de uma forma mais bacana, de uma forma menos hierárquica, mais transparente, também influenciou o modo como eu interpretava depois os outros movimentos e como as coisas se davam.

E esse sentido de poder ousar, de poder pensar diferente, de poder desafiar o estabelecido, o status quo, de ter uma perspectiva crítica em relação ao Estado, ao mercado, que acho que quando se fala de Centro de Mídia Independente se fala disso. Enfim, são coisas que me atraíam muito na época e mesmo ainda hoje, apesar de eu não estar mais no coletivo.

Não vou falar que era um mar de rosas; é claro que tinham brigas, que tinham questões de poder, tinha conflito, quer dizer, tinha um monte de coisa. Como acontece em todo grupo, toda organização ou coletivo com fim político, havia diferenças de perspectivas em relação ao papel do CMI, mas eu não consigo lembrar de algo pontual. 


\section{E em relação ao modo como CMI funcionava, tinha alguma coisa que você não achava legal, que poderia ser diferente?}

Com o tempo eu acabei desanimando um pouco. Primeiro porque eu comecei a achar a estrutura muito pesada. Ao mesmo tempo em que tinha uma coisa muito legal de discutir tudo, isso acabava deixando a estrutura muito pesada, o que até influenciou um pouco na minha saída. Havia debates intermináveis sobre coisas que talvez não fossem tão importantes. Isso aconteceu quando a coisa cresceu muito - porque quando eu entrei no CMI havia três ou quatro coletivos no máximo. Quando a coisa cresceu muito, todos os processos ficaram mais complicados, e acabou sendo difícil de gerenciar o coletivo, porque tudo tinha que ser discutido, e era muito mais gente discutindo, muito mais gente com diferentes perspectivas, inclusive de coletivos regionais. Isso acabou atravancando um pouco, contribuindo para que as coisas ficassem mais morosas.

O CMI lidava também com assuntos que desafiavam a ordem institucional, e trabalhava com movimentos que praticavam desobediência civil, e de certo modo desafiava o Estado, desafiava a lei, e isso trazia questões de segurança que eram complicadas. Mas também traziam um dilema: como um grupo que quer influir politicamente, que quer acessar as pessoas, as mais diferentes pessoas, ele tem que se abrir um pouco para o mundo, ao mesmo tempo em que tem que garantir sua segurança, e a segurança das pessoas envolvidas nas coberturas. E isso criava situações meio complicadas também. Em alguns momentos eu acho que o grupo se fechou muito, mesmo por questões de segurança, que eu acho legítimas, que são compreensíveis, mas que penso que esse dilema não foi tão bem resolvido na estrutura interna do CMI. Debates que eram para ser mais amplos, que podiam ser mais amplos - e a maioria, na verdade todos os debates do CMI não causavam problema nenhum em serem mais amplos, abertos - acabavam sendo fechados.

\section{Em lista fechada, você diz?}

Sim, em lista fechada, ou entre as pessoas que às vezes tomavam muito cuidado. Então essas são questões que em algum momento me incomodaram.

\section{Um exagero na preocupação?}

Sim, um exagero na desconfiança em relação a quem chega. Porque não se estava fazendo nada ilegal. Não tem nada ilegal. E mesmo que tivesse, no âmbito da 
desobediência civil, ninguém vai matar por matar alguém do CMI, enfim, nada disso. Era muito no âmbito da ação coletiva, da desobediência civil. É claro que complica quando se começa a trabalhar com outros movimentos um pouco mais de gente grande". Mudar o nome de uma placa é diferente de ocupar um prédio, ou ocupar um terreno. Entendo as preocupações em relação à segurança, do site ser um ambiente seguro para os movimentos usarem o CMI como ferramenta, porque a proposta era que os movimentos usassem o CMI como ferramenta, e aí a segurança tem a ver com criar um ambiente seguro para isso, mas é complicado do ponto de vista do público que quer influenciar no debate.

Conte alguma experiência ou algum acontecimento que tenha lhe marcado mais dentro do CMI, positiva ou negativamente.

O que me marcou mais foram dois momentos: o Fórum Social Mundial - um dos primeiros, acho que em 2002 -, que foi muito bacana como crescimento político individual.

\section{O que vocês fizeram como CMI nesse Fórum?}

Havia um plano de se fazer um Fórum paralelo para se discutir a proposta da autonomia, da autogestão, do anarquismo, e nós íamos ocupar um lugar no Fórum e fazer desse um lugar de discussões paralelas. Acabou não rolando por problemas operacionais, mas foi muito bacana porque eu tive uma dimensão do que é esse movimento de uma forma mais próxima, do que era o CMI em termos internacionais. Foi uma ocasião em que eu acabei conhecendo voluntários dos Estados Unidos, da Itália, e de uma série de outros lugares. Trocar com essas pessoas foi muito especial e me deu um pouco a ideia do que era essa dimensão global do CMI. Lá também nós tínhamos um espaço de produção de mídia independente. Tive contato com o pessoal das rádios livres, do Software Livre, e de outros grupos, e essa troca foi muito bacana para discussão sobre mídia.

Outra coisa marcante para mim no CMI foi o envolvimento com o movimento dos sem-teto, e o movimento de ocupação. Foi uma grande experiência chegar mais próximo dessa realidade. Eu nunca havia entrado em uma ocupação e era impressionante como realmente fazia muita diferença o CMI estar presente nos momentos das desocupações, em que poderia haver problema com a polícia, enfim, de o CMI documentar esses conflitos. Mostrar também como as pessoas viviam nas 
ocupações e o que se reivindicava. Quer dizer, a gente sentia que o trabalho fazia muita diferença, porque eram movimentos que a mídia estava completamente contra, ou então não dava a mínima para eles. A gente sentia um papel muito importante de denunciar, ou até mesmo coibir qualquer episódio de violência policial. É claro que a gente não conseguia sempre, e acabava tomando porrada às vezes, mas pelo menos estava sendo documentado - e, se não fosse a gente, nem isso estaria acontecendo. Então acho que ganhava muito sentido participar. É uma pena que realmente não deu para aproximar esses movimentos a ponto de eles mesmos usarem o site como ferramenta, mas de qualquer forma foi uma experiência bem bacana.

Outra coisa também que eu sempre gostei de fazer eram as oficinas, falar com as pessoas, participar de debates - achava que eram coisas importantes.

\section{Oficina sobre o quê?}

Sobre publicação aberta, como funciona o CMI, qual a proposta, como se pode publicar. Sempre iam alguns voluntários. Não foram tantas as oportunidades, mas eram oportunidades legais.

Gostaria que você falasse mais, de uma maneira geral, do que vislumbra da situação da mídia no Brasil.

É complicado porque, na maior parte das vezes, nós falamos de mídia corporativa, grandes conglomerados de mídia quando se pensa em mídia de massa, comunicação de massa. E aí tem todas as questões, primeiro de não se desafiar o que é o senso comum, o que é estabelecido, então fica sempre em um discurso mediano. Tem a coisa também do famoso rabo preso: a mídia está em massa em uma rede de interesse dos mais diversos, e não necessariamente interesses que têm a ver com as camadas da população que têm menos poder de voz - os mais pobres, os LGBT, as mulheres. Não dá para dizer que a mídia tem um comprometimento nesse sentido, muito menos uma responsabilidade em termos do que veicula, então esse é o cenário da mídia maior. Fora isso tem alternativas, mas o difícil é fazer frente a esse cenário, porque quem detém as licenças para o meio de comunicação, detém parte dos meios se for pensar em televisão, rádio - e é outra escala, é outra coisa. Por outro lado, e acho que o CMI também tem a ver com isso, as coisas mudaram muito com a internet e as mídias instantâneas. Isso deu acesso muito maior às pessoas, muito mais pulverizado, porque há uma diversidade de iniciativas, não é como estar metade do 
Brasil assistindo ao Jornal Nacional. Eu acho que isso colabora em algum sentido. Mas nem por isso também a internet deixa de ter seu lado comercial.

\section{Não é a solução final, é isso?}

Não, porque é um acesso delimitado a meios específicos, e que também são acessados por determinadas camadas da população; não é mídia de massa. Mas acho que não é só o acesso aos meios, mas sim o que você faz com isso. E é complicado, é difícil, mas tem alternativas. Eu tenho um blog, por exemplo, que é meu instrumento de pesquisa, mas também é um lugar em que cada vez mais eu posto as coisas que eu tenho vontade, e que têm um teor político, às vezes. Claro, eu não passo para quase ninguém, mesmo em comparação com o CMI, deve ter umas seis pessoas que lêem meu blog. Ninguém comenta, pelo menos.

Isso, aliás, era uma coisa em que eu acho que o CMI vacilou um pouco. Porque o CMI já existe há muito tempo, e tudo o que foi construído foi com muita discussão, muito trabalho, só que nesses anos que o CMI está aí, as coisas ficaram muito mais rápidas, instantâneas, mudaram. Talvez para CMI fosse legal pensar agora em uma estrutura mais ágil, mas não sei como fazer isso. Mas a coisa dos blogs - eu vejo também por causa da minha pesquisa de doutorado: tem uma serie de blogueiros gays que espalham informações. Sai em um blog, no outro, e de repente a coisa se espalha de uma forma tal que eu fico impressionada. É uma rede de indivíduos, e as mobilizações se espalham. E blog não é uma coisa muito nova, estão surgindo e vão continuar a surgir cada vez mais novas mídias e as pessoas vão ter acesso, mas a questão é saber e conseguir utilizar isso de uma forma que aproveite a rapidez dessa coisa toda, mas não superficialmente, e sim de uma forma inteligente politicamente falando. Eu fiquei impressionada também com o Twitter. Por exemplo, uma pessoa postou uma proposta de manifestação no Twitter, e em alguns dias de repente 20 mil pessoas estavam lá. Agora a briga é como que a gente pode usar isso. Como que a gente vai brigar no Twitter para, por exemplo, não virar uma ferramenta só da Época, da Veja, da Folha. Elas estão todas no Twitter também. E como é que nós, pessoas comuns, que não temos grandes patrocinadores para as nossas causas, como é que se vai usar essas ferramentas todas de uma forma a criar ação coletiva? Acho que esse é um dilema, porque muitas vezes elas são usadas de forma individualizada mesmo. Mas em alguns momentos você vê um potencial enorme delas se usadas para a ação coletiva. O CMI se beneficiou muito disso. Com a publicação aberta e a coisa das 
listas, há uma organização que é global e em que as discussões se dão, na maioria das vezes, de forma virtual, o que é uma coisa notável. Acho que o CMI usou muito, mas deve olhar para isso cada vez mais. Parou um pouco na estrutura pesada, mas esses modelos continuam aparecendo, essas novas ferramentas, e acho que é tentar pensar como usar isso para a ação coletiva. E entrar na briga.

Partindo do princípio que também é jornalismo o que se faz no CMI, qual é o papel do jornalismo para você, de maneira bem geral?

Nunca pensei nisso.

Porque você foi, ou ainda é jornalista, através do seu blog, de alguma maneira...

É, na verdade essa coisa do blog você acaba repercutindo mais do que fazendo notícia.

\section{Mas você cobriu, fez cobertura...}

Sim, para o CMI com certeza. Difícil pensar, mas eu acho que no sentido do CMI era um pouco disso, de comunicar algo. E comunicar uma informação de qualidade, responsável, politicamente comprometida. Quer dizer, tinha um sentido, aquela coisa do CMI de buscar uma sociedade mais justa, igualitária, que preserva o meio ambiente. Isso tem um sentido para o jornalismo que se fazia ali. Então acho que transmitir informação, não necessariamente, mas na maioria das vezes, não hegemônica, de coisas que você não vai ver no Jornal Nacional o tempo inteiro - ou se pelo menos você vai ver, filtrar essa informação de forma diferente. E pensando nisso, na promoção de uma sociedade mais justa, de uma sociedade melhor, então é uma informação comprometida politicamente. Mesmo no meu blog eu falo um monte de bobagem, você vai ver lá a tag "inutilidades", uma das que mais tem conteúdo, mas tem um sentido. Eu sempre escrevo coisas que estão relacionadas ao meu dia-a-dia, mas que também transbordam para um universo maior. Como estou inserida um pouco na coisa LGBT, eu acabo comentando muito as coisas relacionadas ao LGBT, à sexualidade e ao gênero, e faço muito uma coisa de cotidiano. Por exemplo, hoje fui, por motivos profissionais, no albergue conversar com as travestis que estão lá albergadas, e aí eu fiz um texto falando de toda a condição que é estar albergada como travesti e como é complicado, como só tem um albergue que permite a elas se 
vestirem como mulheres, e como nos outros é uma violência para elas terem que botar roupas do sexo masculino. Então é engraçado, porque é uma coisa profissional, por causa de uma pesquisa que eu estou envolvida, relacionada a saúde e travestis, mas aquele foi o lugar de eu poder - para além da pesquisa que só vai ter resultado depois e não dessa forma - externar isso, passar essa informação. Comunicar essa injustiça e levar isso adiante.

E isso era uma coisa muito legal no CMI - você sabe pelo jornal, você sabe porque você leu, você sabe porque alguém conta, você sabe porque esse jornal é da sua casa; mas a experiência de falar com as pessoas e sentir de perto o seu drama e suas dificuldades é algo totalmente diferente. E no meu blog tem muito disso, de tentar transformar aquilo que você passa e nem vê, tentar humanizar aquelas histórias.

Há um lado também - e isso acabou atrapalhando e foi um dos motivos pelos quais eu saí do CMI - muito difícil depois de 10 anos ativa em movimentos sociais, pesadamente. Chega uma hora em que está tudo uma bagunça e você precisa se voltar um pouco para sua vida pessoal, família, estudo - tem uma tese pra fazer, casa para sustentar, namorada para dar conta, mãe, pai, enfim, é complicado dar conta de tudo. Então, por mais que você veja sentido político nas coisas que você está fazendo, fica difícil conciliar a coisa do ativismo com tudo isso o tempo inteiro. Mesmo no meu blog eu tento colocar coisas diferentes também, não vou encher só de política que ninguém mais vai ler, entendeu? Vou colocando as coisas meio que paulatinamente, mas também vou colocando coisas que me divertem sabe? Que me dão prazer de colocar ali. Mas enfim, o que eu ia dizer é que tudo isso torna complicado você fazer um trabalho realmente consequente, dedicado, político, mas a gente tenta fazer na medida do possível.

Outro aspecto que esqueci de falar quando você perguntou sobre o que eu mais gostava, é que, para mim, o CMI tinha uma coisa onde prazer e ativismo andavam muito juntos, então toda essa coisa de falar com essas pessoas, ou mesmo de aprender com as ferramentas, de fotografar, e um pouco do que eu sei de edição de áudio, de HTML, de aprender coisas, tudo isso era muito vívido e gerava uma atuação muito prazerosa. Diferentes convivências, diferente dessa idéia mais tradicional de política que é só chata, que é só trabalho, só obrigação. Era uma coisa que você fazia com tesão de aprender, com tesão de conhecer o novo, então tinha esse lado que é uma coisa que também curto no blog, pesquisando coisas. O post que eu ia colocar, e então pensava: tem que colocar um link aqui para o fulano. E então ia caçar na Wikipédia, e 
de lá já via um negócio e falava "pô, eu não sabia isso". É uma coisa prazerosa, pois você vai caçando muito mais coisas. Acho que eu dei uma direcionada agora, porque é tanta informação... Por exemplo, meu Twitter está carregado com um monte de informações e eu mal consigo ler. Então tem que dar uma limpada. O problema dessa abundância de ferramentas é isso, também tem um monte de informação que vem de todo lado e que não necessariamente é uma informação de qualidade e comprometida socialmente.

\section{Tem mais alguma coisa que você queira falar?}

Eu fico chateada de não estar no CMI agora, mas eu acho que é complicado conciliar esses âmbitos todos da vida, sabe? E a proposta é de que não seja um fardo você ter uma atuação política. Não pode ser um fardo para sua vida. Então tem que ser com tesão, com prazer, e tem que ser uma coisa que esteja mais ou menos integrada. Chateia o fato de eu não ter conseguido conciliar, nesses últimos, anos esse lance todo. E acho que o CMI não descobriu ainda - embora o CMI tenha uma estrutura muito mais móvel que a maioria dos outros grupos - como lidar como coletivo com os momentos pessoais, com os momentos das pessoas para se dedicar mais ou se dedicar menos. Isso é complicado em termos de coletivo. Enfim, é complicado, porque quem esta lá na reunião todo o tempo vai se ressentir se você passar um tempo só mandando email, ou só atuando via internet, e tem toda razão. Mas, ao mesmo tempo, tem que descobrir um jeito de conseguir manter toda uma estrutura flutuante em volta que não está absolutamente comprometida, para não perder os ativistas. Eu tentei ficar flutuante, em volta, por um bom tempo, mas não rolou. Chegou um momento que eu me sentia como se estivesse sacaneando o grupo, quer dizer, fazendo corpo mole e o pessoal trabalhando. Eu me sentia mal de estar naquela posição, mas há de se pensar em como que a gente consegue articular diferentes modos e momentos de atuação política para as pessoas, para que se consiga manter essa rede. Eu tenho perspectivas, não sei se de voltar ao CMI, mas de voltar a participar de um grupo com uma ação coletiva. Eu também fiquei muito tempo na Associação da Parada, e é muito mais árduo, muito mais desgastante do que qualquer atividade no CMI que eu tenha participado. Também deu um cansaço, mas eu tenho perspectiva de voltar a atuar de uma forma mais coletiva. Não sei se o CMI me atrai tanto, por causa disso, dessas condições. É muito mais fácil eu pegar uma coisa, escrever aqui rapidinho e botar no 
meu blog. Então, eu não sei, acho que a questão aí é discutir outros formatos, outras possibilidades para voltar a participar. Tenho isso como perspectiva.

\section{Marcelo "Tech"}

Atuante no CMI em mais de uma frente, mas sobretudo a tecnológica, Marcelo leva os ideais do movimento do Software Livre, comungados pelo CMI, às práticas do grupo. Em sua entrevista, apresenta algumas peculiaridades do CMI Brasil, como algumas características que, para ele, lembram a anarquia - posição política que ele defende, e o fato de ser independente financeiramente de qualquer empresa, grupo ou indivíduo em particular.

Marcelo relata que a Rede Indymedia foi a primeira experiência da web 2.0, sendo seu site diferenciado dos das empresas e corporações que seguiram esta tendência, entre outras coisas, pelo uso "banal" que as pessoas fazem dos mesmos, e por não recolher contrapartidas dos usuários, como o fornecimento de dados para pesquisas de mercado. Ele explica também o conceito de ação direta, que é adotado em manifestações pelo grupo do CMI e por boa parte dos movimentos associados a ele, como a Rádio Livre.

\section{Primeiro eu queria que você contasse como começou a participar do CMI.}

$\mathrm{Eu}$ comecei por indicação de um amigo meu, anarquista, e como somos dois anarquistas, um dia ele falou para eu ir no CMI, que ia gostar, etc. Uma coisa curiosa no começo é que no CMI o pessoal tinha muito medo de polícia, de repressão, o que tem os seus porquês. Então, para o pessoal ter confiança em mim demorou de dois a três meses. Mas eu já sabia disso, então esperei. Qualquer outra pessoa que não soubesse, talvez se enchesse, perderia a paciência e sairia do CMI.

\section{Mas que tipo de medo havia?}

Eles pensavam que eu era um policial infiltrado, por causa da minha postura. Eu tenho um jeito sério de falar, cabelo cortado [risos]. Eu não sei exatamente por que, mas eu sabia que eles tinham um pouco essa paranóia. Hoje isso já não existe mais, o CMI já está mais tranquilo, apesar de a gente ter sofrido algumas perseguições a que eu mesmo assisti... Eu entrei em outubro de 2002, e de lá para cá muita coisa aconteceu. 
No Brasil teve uma coisa que foi séria, na época em que houve os protestos contra o Papa Bento XVI, porque ele foi da juventude nazista, colocaram uma imagem dele com a suástica, e então dois amigos nossos foram visitados - e a gente suspeita que tenha sido pela Interpol. E essas pessoas, que eles não chegaram a encontrar na hora em que apareceram, perguntaram para os vizinhos quem eles eram, e como coringa, para conseguir a cooperação de todo mundo, falaram que estavam investigando um caso de pedofilia, porque assim todos iam ajudar, abrir a boca, etc. E ficou muito mal para os meus amigos. O clima pesou, porque isso se espalhou, e foi uma coisa muito desagradável, eles até mudaram do local onde moravam.

Na Itália também houve um caso que foi sério. Nós temos email seguro - e não vou discutir aqui sobre direito à privacidade. Mas, na Itália, a polícia conseguiu de alguma forma conversar com o provedor para quebrar essa segurança, e a polícia lia seis mil contas de email, durante três meses, até isso ser descoberto. Então há essas coisas que acontecem.

E vale a pena mencionar o sequestro do servidor principal do CMI em 2007, a mando do FBI, por um pedido de outro país, que por acaso era a Itália também.

\section{E o que te atraiu para entrar no CMI?}

O que me atraiu? Nada. Talvez fosse melhor você perguntar o que me manteve lá. Eu fui conhecer a proposta do CMI com eles mesmo, não cheguei sabendo. E mesmo assim, eu só fui entender o CMI, ou ter minha concepção do CMI bem depois. Mas o que me manteve foi o projeto de as pessoas serem a mídia, de não ficaram só acreditando em televisão, saber que existem versões dos fatos. Além de ser uma coisa horizontal, para mim que sou anarquista. Quer dizer, ele tem uma formação, não exatamente anarquista, mas uma horizontalidade, um trabalho com consenso, que lembra a anarquia. E tem uma base anarquista por causa dos fundadores e das pessoas que o mantêm.

\section{Todos os coletivos ou o do Brasil especificamente?}

Não, o do Brasil é diferente dos outros países. Nos Estados Unidos, por exemplo, há alguns coletivos que acham que é legítimo receber dinheiro de organizações ou de empresas, e a gente é contra. Não aceitamos dinheiro nem de ONG, só de pessoas físicas, ou com a venda de uma camiseta, um DVD. Temos esta postura, com que eu particularmente concordo muito. Mídia alternativa que recebe 
dinheiro de fundação já existe. O CMI é o grande veículo de mídia alternativa no mundo que não tem financiamento de ONG ou empresas. Então é uma experiência sociológica única; se começarmos a aceitar dinheiro vamos ficar igual a todo mundo. Não que eu seja contra mídia alternativa que receba dinheiro de governo, fundação, mas acho que temos que ter esta diversidade: os diversos tipos de mídia, tendo suas próprias características. Quando falamos "Centro de Mídia Independente", é independente de fato, inclusive financeiramente. O interesse é dar voz ou mostrar as versões que não aparecem na grande mídia. Só. Não tem rabo preso com nada.

\section{E o que mais tem "mantém" no CMI?}

O CMI tem um potencial grande, mas atualmente não sabe o que fazer. Ele precisa se reinventar. A internet como a gente conhece hoje mesmo, o primeiro grande movimento de web 2.0, foi o Indymedia. A ideia de as pessoas publicarem elas mesmas foi apropriada por toda a internet, inclusive pelos sistemas capitalistas. Hoje há blogs, fotologs, Twitter, Orkut, muitas coisas de graça, mas as pessoas publicam onde? No site de uma empresa. Uma empresa que normalmente está analisando o que você está escrevendo e gerando base de dados para estatísticas e pesquisas de marketing. Como é que Gmail, Hotmail, todos eles, fornecem tanta coisa de graça? $\mathrm{Na}$ verdade, não é de graça. Lá nas letrinhas pequenas desses contratos que você aceita está escrito que eles podem gerar informação a partir do seu conteúdo. E isso acaba com toda a privacidade da pessoa.

Enfim, mas quem começou este movimento mesmo, em 1999, foi o Indymedia, mostrando que isso era viável. Não se tornou um movimento mais conhecido porque não tem um apelo de marketing - o CMI não faz publicidade, e nem tem dinheiro para isso. Outra coisa que cresceu mais notoriamente foi, por exemplo, a Wikipedia. Mas ainda assim o CMI tem um potencial enorme, para alguma coisa diferente. Isso pode até ser alguma espécie de fé minha, enfim. Mas ele está em um momento em que está precisando se reinventar. Está completando 10 anos, e precisa descobrir alguma coisa que seja uma grande novidade, e que desta vez não possa ser copiada sem prejuízo pelo capitalismo. 
Para você então precisa de "novidade”? Não basta fazer o que já vem sendo feito?

Bastaria sim, mas ainda precisa ter uma modificação no formato. Talvez não na proposta. Eu não mudaria o projeto do CMI. Mas o modo como ele se apresenta para a sociedade, como está sendo distribuído, ainda precisa de alguns ajustes, mais técnicos do que teóricos. Com relação à organização, também não precisa de tanta renovação, muito pouco. O CMI já tem uma estrutura organizacional global super consolidada, que funciona.

Existem, é claro, problemas pessoais, e esse hoje acho que é o maior problema do CMI, já emendando outro assunto. As pessoas têm muita liberdade, e talvez não saibam lidar com esta liberdade, e acabam discutindo, brigando. E, boa parte das vezes, saem do CMI reclamando do CMI, quando, na verdade, foram brigas pessoais que tiveram - eu mesmo já tive problemas, e fiquei dois anos afastado por causa de um problema pessoal, na época em que eu cuidava das finanças do coletivo. Mas eu nunca falei mal do CMI, que é maior que minha briga pessoal e que meus simples entendimentos.

Com o que você trabalha no CMI? Sistemas, informática, por ser engenheiro?

Não, eu já fiz editoriais também. Eu acabo sendo mais técnico por causa da minha formação, mas no CMI você não precisa ser técnico porque você é engenheiro, você pode ser repórter.

\section{E nesta área técnica, o que você faz exatamente?}

A licença do CMI, que é copyleft, a nossa própria forma de distribuição de notícias, é inspirada no Software Livre, que é um movimento anterior ao próprio Indymedia. Queríamos então fazer as coisas com softwares livres, e no começo eu fazia testes. Ia na casa das pessoas, instalava Linux para elas, ensinava como usar. Também tinha uma questão de segurança, porque o Windows é muito vulnerável. Como a gente é visado, digamos, pelos falsos democratas que existem pelo país, tínhamos um certo receio de polícia ou governo começarem a colocar softwares espiões entre os nossos computadores.

Queríamos ter um trabalho seguro, com uma comunicação segura. Por exemplo, o que chamamos de ocupação, dos sem-teto, que a grande mídia chama de 
invasão. Quando os sem-teto resolvem fazer uma ocupação em algum prédio abandonado, ou que não está cumprindo sua função social, às vezes nos avisam com antecedência, para acompanharmos, cobrirmos, filmarmos. Não exatamente fazer a ocupação, mas estar lá, mostrando o que está acontecendo. Até porque a gente tem uma clareza muito grande de que, quando você leva uma filmadora, a violência policial diminui. Isso é algo consumado, já verificado, sabemos disso. Então não queremos trabalhar com tecnologias de comunicação inseguras, para a polícia saber com antecedência e já reprimir a priori. Não temos nada a esconder, mas há coisas que não são nossas, que são de outros movimentos, e a gente tem que dar uma segurança para esses movimentos.

\section{Você já era ativista em algum outro lugar antes de entrar para o CMI?}

Não. Não tinha também nenhum envolvimento com partido, com grupo anarquista... E naquela época não existia nem a bicicletada como movimento, só como grupo. Eu participava da lista brasileira de ciclismo, mas era mais uma lista de encontro, não de ação - não os considero um grupo ativista.

\section{O CMI, pelo menos o coletivo de São Paulo, tem alguma conexão maior com} certos movimentos, como o dos sem-teto?

O CMI sempre buscou proximidade com os movimentos sociais diversos, de todo o tipo, inclusive tentando levar esta ideia dos movimentos fazerem suas próprias mídias. Então, por exemplo, hoje há o site do Fórum Centro Vivo, que foi uma pessoa do CMI que ajudou a fazer. O CMI adquiriu um know-how técnico e começou a ajudar outros movimentos a terem seus sites, etc. Mas queríamos muito que tivesse uma pessoa de cada movimento dentro do CMI, para falarmos sobre a técnica jornalística, de redação, e levar essa consciência sobre mídia, sobre imprensa, para dentro dos movimentos.

E sempre abrimos o site para eles mandarem seus editoriais, o que querem que a gente coloque com destaque - até por que o CMI tem uma facilidade: se algo entrar no CMI Brasil, pode se espalhar para o mundo. Já tivemos oficinas de jornalismo, por exemplo, mas menos até do que deveríamos fazer. Acho que a gente deveria fazer isso mais vezes. Mas no momento não temos fôlego para isso. 


\section{E o que mais você acha que poderia melhorar no CMI, no geral?}

Essa é uma pergunta muito difícil de responder. Para o aniversário de dez anos do CMI, em 2010, que o coletivo global está decidindo onde vai ser e tudo mais, uma coisa já está acertada: não vamos discutir problemas passados, só pensar para frente. Então realmente eu ainda não sei, é algo complexo. O que o CMI tem que tentar é fazer mais parte da vida das pessoas. E isso vai acontecer no boca-a-boca mesmo. Com o tempo a sociedade vai conhecendo o CMI. Precisa também melhorar um pouco a qualidade dos editoriais. Há uns três anos atrás tinha uns editoriais melhores. As pessoas procuravam se aprofundar mais. O CMI tem que fazer um jornalismo mais investigativo, a gente não pode fazer um jornalismo de massa.

\section{E como você diferencia os dois?}

Pela profundidade mesmo. Pode haver um jornalismo na grande mídia bom, mais analítico, mostrando mais de uma versão. Essa noção de versões de fato é uma coisa que deveria ser passada para as pessoas desde o ensino médio, na minha opinião, antes de virarem eleitores.

O CMI para você é um movimento social ou é um veículo de um movimento?

É um movimento, não é um veículo, porque as pessoas se reúnem por um propósito, e por algumas afinidades que elas têm. Como em qualquer movimento, há alguma ação, iniciativa ou propósito e as pessoas se reúnem por aquilo. Reúnem-se, como a gente gosta de chamar, em um grupo autônomo, que é um tipo de organização civil que não é reconhecida juridicamente. Em um país você tem empresa, sociedade anônima, sociedade limitada, organização não-governamental, mas não existe grupo autônomo. Não sei se isso é bom ou se é ruim, mas de qualquer forma a constituição brasileira protege este tipo de reunião de pessoas.

\section{Para você, a tecnologia contribuiu para os movimentos sociais?}

O CMI foi o primeiro grande movimento que se alastrou pelo mundo de web 2.0. A web 2.0, tecnicamente se alastrou, mas o propósito do CMI não. Quer dizer, as pessoas fazem uso da tecnologia e do poder da internet para publicar coisas banais, como ter um blog para discutir o vestido da fulana que estava em uma festa, ou mostrar suas fotos de viagem - o que não é algo exatamente banal, mas não tem nenhum propósito ativista, de modificar o mundo, de melhorar a sociedade. Então a 
tecnologia melhorou sim, a mídia. Tecnicamente, as pessoas conseguem se enxergar mais, mas o uso que fazem desta tecnologia ainda é muito pífio perto do que elas poderiam fazer. No Brasil a gente tem bastante iniciativa de governo eletrônico, governança na internet. As pessoas poderiam tomar suas decisões pela internet.

\section{Mas ainda não têm essa vontade...}

Não têm vontade e não têm preparo. Nossa educação não prepara a gente para isso, mas para o modelo que aqui está, não para um modelo diferente. Está certo que no momento, pelo menos no caso do Brasil, a gente não têm nada que possibilite a tomada de todas as decisões pela internet. Mas como sou engenheiro, sei que é tecnicamente possível, por exemplo, eliminar a Câmara dos Deputados - e as próprias pessoas fazerem os projetos de leis, trocando informações. É claro que não podemos tirar tudo de uma vez, mas a primeira coisa que eu eliminaria, sem dúvida, seria a Câmara dos Deputados. Com tanta tecnologia, se as pessoas fossem formadas para serem críticas - que não é o que acontece...

Para mim vivemos num sistema dito democrático que não é nada democrático. A própria palavra "democracia" é muito contaminada. O sistema representativo não legitima de fato um presidente da república a dizer que está lá representando uma nação. E nem na democracia participativa. Então o CMI tem aquela coisa de ação direta, que vai no sentido de uma sociedade mais justa, que hoje poderíamos traduzir como democracia direta.

\section{E o que é ação direta?}

É algo que o CMI faz, assim como alguns movimentos sociais. O movimento dos sem-teto, por exemplo: tem um prédio há dez anos desocupado, e aí um monte de gente com necessidade de morar em algum lugar... Eles vão lá e ocupam. O CMI, quando fez o protesto lá na Avenida Roberto Marinho, uma intervenção urbana, renomeando a avenida para "Vladmir Herzog"... Eu mesmo colei quatro placas. Então você fazer esta intervenção direta no meio público - e que não foi depredação, apenas colamos adesivos... Eu sou contra a depredação.

Outra terminologia associada a isso é o que chamamos de desobediência civil. As leis são construídas por um grupo de pessoas que não representam a sociedade, feitas principalmente para este grupo de pessoas - e se não estão nos atendendo vamos lá e subvertemos mesmo, desobedecemos. Há, por exemplo, até uma juíza 
federal, em relação ao movimento de rádios livres, que escreve: desobedeça, faça a rádio livre. O pessoal chama de "rádio pirata" e a gente sabe que, tecnicamente, não tem nada a ver isso, de que derrubam avião ou interferem com a comunicação da polícia - mesmo porque, se alguém derrubasse avião, seria a Jovem Pan, a Transamérica, de mil, dois mil watts de potência, e não uma rádio livre ou comunitária. Então sabemos que há muitas mentiras, ditas pela própria Anatel. A Anatel para mim é uma grande droga. Infelizmente, esse modelo de agências do governo, que vem do governo Fernando Henrique, em algumas coisas foi positivo, mas em outras muito negativo, e a Anatel é uma delas. Eu sou a favor de que as universidades públicas fizessem o papel da Anatel, em seus cursos de rádio, televisão, com a participação dos estudantes. Sou muito mais isso do que uma agência que regulamenta a favor de uma elite. Então, rádio livre é outra forma de ação direta.

\section{Chamou sua a atenção a identificação, afinidade que você sentiu entre a sua} visão política e o que você encontrou quando chegou ao CMI?

Sim, mas não só isso. Mais o potencial que o CMI tem de modificar a sociedade. A gente não é só um grupinho fechado que fica lá discutindo opiniões. Esse potencial - não vou falar de motivação, porque a gente sabe que motivação é uma coisa intrínseca, mas de estímulo, talvez - de as pessoas pensarem um pouco mais. Vemos estudantes de comunicação, pessoas de vários lugares, que entram no CMI e começam a ler as matérias... Não dá para entrar no CMI sem mudar um pouco a sua consciência, sua percepção a respeito da mídia. Isto, para mim, é literalmente ótimo. Então não é só um grupo de afinidade que discute entre si, mas com este potencial de expansão.

\section{Algo mais que você queira acrescentar?}

Infelizmente, a gente tem uma carga de trabalho grande, e a sociedade é construída para isso: para as pessoas não refletirem. Se elas não ficassem tão esgotadas, tendo, por exemplo, uma jornada de seis horas de trabalho, poderiam usar as outras duas para fazer ativismo... [risos] Já ia dar uma boa modificada. Isso acontece comigo também. Se as pessoas conseguirem ter um tempinho a mais para não ficar somente nos postos de trabalho estabelecidos ou fazendo coisas relativamente fúteis na internet - Orkut, MSN... Se elas pegarem um tempinho... Cada pessoa no Brasil pegando duas horas por semana para fazer ativismo seriam 200 
milhões de horas de ativismo! Parece pouco, e até um discurso retórico, mas se cada um fizer um pouquinho... Vemos ONGs assistencialistas dizendo coisas parecidas, e ajudam. Parte das pessoas podem fazer sim as ações assistencialistas, que são importantes, mas outra parte tem que fazer as ações ativistas, e deveria aumentar o número deste segundo grupo.

Não sei se dá para fazer um paralelo, mas sinto que estamos caminhando para um sistema muito parecido com a ditadura militar. Eu não sou filósofo - e os filósofos devem reclamar muito dessa minha entrevista, pelas palavras usadas, mas eu chamaria de totalitarismo. É basicamente uma sociedade controlada, em que as pessoas não acreditam que estão sendo controladas: "estou com comida no prato, estou com emprego, então está tudo certo". Não importa quem colocou a comida no seu prato ou criou este emprego, desde que tenha isso. Então as pessoas estão numa sociedade de controle e deixam de experimentar sua própria humanidade; são mais ferramentas de uma estrutura organizacional e governamental do que propriamente pessoas pensantes que querem modificar suas condições de vida. Estamos num caminho perigoso. Eu percebo muito isso. O governo Lula é muito isso, o governo Serra é muito isso. Os dois grandes partidos que temos hoje estão direcionando bastante a sociedade neste sentido, de se construir essas estruturas totalitárias que são simpáticas, mas que tiram das pessoas sua essência maior, que é o próprio intelecto humano.

\section{Foz e Drebs}

Participante quase sempre presente nos eventos e reuniões do período que acompanhamos o coletivo do CMI em São Paulo, Foz declaradamente gosta do contato com pessoas e suas experiências, daí a valorizar especialmente a rede de trocas entre grupos e indivíduos que a Indymedia representa. Jornalista de formação, nunca atuou profissionalmente na área, e mostra-se bem decepcionada com a formação, para ela restritiva, que as faculdades de jornalismo em geral proporcionam. Reafirma em seu depoimento a crença de que as pessoas podem elas mesmas falar da sua realidade, com o menor uso possível de intermediários, concepção que ela deseja trazer cada vez mais para a prática do CMI - embora isso nem sempre seja possível, devido ao acesso pouco democrático aos meios tecnológicos e de comunicação.

Para ela, embora haja diversas coisas a melhorar - e que estão sendo discutidas e postas em prática na elaboração do novo site - o CMI evoluiu muito, em particular quanto a uma variedade maior entre os participantes, originários de diversos 
movimentos e de perfil variado, ao contrário das acusações que o grupo sofria no início, segundo ela, de ser um "um bando de burguesinhos da USP e dá PUC (...), pessoal só de universidade, e que daí era muito fácil”. Enfatiza bastante em suas falas também a incompatibilidade do jornalismo com o comércio, já que deste modo sempre haveria interesses econômicos e políticos cerceando a atividade.

Atuante na parte de tecnologia, Drebs, cuja entrevista não estava de início programada na ocasião, fez algumas intervenções na fala de Foz - em particular apoiando a crítica à mídia comercial - e acabou dando um pequeno depoimento de sua participação no CMI também.

Primeiro eu queria que você falasse quando e como você conheceu o CMI, sua participação, e um pouco do seu histórico no projeto desde então.

Eu era do interior e vim para São Paulo em 2000. Desde que cheguei eu procurava algum grupo para me envolver, passei por vários grupos, mas todos tinham envolvimento com partido, e isso me deixava super desanimada. E ao mesmo tempo, eu nem sabia que existia organização autônoma, movimento autônomo. O próprio anarquismo, eu conhecia muito pouco.

Você diz que procurou grupos, que tipo de grupos?

Políticos...

\section{Movimento social?}

Sim, social e político. Eu tinha vontade de discutir, de atuar em algum grupo que fosse comunidade, quer dizer, tudo que os grupos autônomos têm como princípios era o que eu gostava. Eu queria fazer parte de um grupo em que eu não tivesse que seguir alguma coisa que o "mestre" falasse, sabe, ou em que alguém fosse mais importante por ser mais velho ou porque teve mais educação, frequentou universidade ou alguma coisa assim. E não consegui achar. Fui em várias reuniões, vários lugares, e nunca consegui. Me chamou a atenção o ato que rolou em 2001 aqui, que foi o A20. Foi a primeira vez que eu ouvi e disse "nossa, que coisa interessante", mas não conhecia ninguém... 


\section{E ficou sabendo por meio de quem?}

Por meio televisivo, por jornal mesmo. Daí eu ouvi falar do $\mathrm{ICAL}^{27}$, não sei se você sabe, que era um espaço que tinha na Vila Madalena, com princípios anarquistas, e que existiu mais ou menos nesta época. Era uma convergência de grupos. Cheguei a ir lá, mas estava fechado, e desencanei. Então, foi em 2003 que, pesquisando na internet, eu conheci o site do CMI e achei muito bacana. Aí fui ver os princípios, mas super desconfiada de que houvesse partido por trás, quem quer que fosse.

Foi até engraçado porque na época eu comia carne e estavam marcando reunião, mas não tinham onde fazer. Daí eu falei: "pô gente, vamos fazer um churrasco lá na minha casa!" E eles me detonaram, assim “meu, quem que é essa menina, já chega aqui falando em churrasco?!" [risos].

\section{Ficaram bravos mesmo?}

Sim, de verdade. Daí eu mandei um email falando: "que isso, pessoal, vamos fazer um churrasquinho de couve-flor" [risos]. Aí falaram, "não, beleza..." e me explicaram que já tinha uma discussão acumulada quanto a fazer reunião na casa de pessoas. Não achavam legal, porque acaba virando um pouco um grupo de afinidades. E preferiam fazer num lugar aberto, para facilitar a participação e para evitar personificação, por exemplo, que alguém que queira participar e não goste de mim, deixe de ir à reunião porque é na minha casa. Nessa época o pessoal estava se reunindo ali na Ação Educativa ${ }^{28}$, foi ali, em 2003 que fui na primeira reunião. Já entrei com um "gazão", assim, porque gostei muito da ideia, debati muito já quando entrei. Queria saber tudo, se realmente era autônomo, horizontal, por consenso. Consenso era uma coisa que eu já pensava que era possível, mas eu não tinha uma ideia teórica, nunca tinha lido sobre consenso.

\section{Você foi entrar em contato com isso no CMI?}

Sim, no CMI. Comecei a ver que aquilo não era uma ideia só da minha cabeça e que tinha um monte de gente fazendo há tempos. Tem discussão acumulada sobre isso, sabe? E o CMI tem essa preocupação de documentação muito forte, documentação de processo, o processo pelo qual passou o coletivo de São Paulo, e eu li uma boa parte dessa documentação, que existe até hoje na rede. É uma

${ }^{27}$ Instituto de Cultura e Ação Libertária, em São Paulo.

${ }^{28}$ ONG. 
documentação muito boa, acho muito especial a documentação do CMI. Lá tinha a explicação de consenso e várias coisas que me deram um pouco de base para discutir melhor entre as pessoas, entender como funcionam as reuniões, as decisões, as listas [de email], que é um pouco complicado de você entender quando começa no CMI, fica um pouco confuso: lista editorial, lista local, lista fechada, lista aberta... No comecinho foi interessante utilizar essa documentação que já tinha sido feita por várias pessoas, mesmo gente que já nem estava mais ali no coletivo, e eu podia aproveitar a experiência, o acúmulo deles, para continuar a partir dali. E ressaltando que nessa época o coletivo estava muito forte, tinha muita gente, muitas atividades.

Além dessas características que você mencionou que entrou em contato, o que mais você valoriza no CMI como um todo?

A rede, sem dúvida. Essa rede de pessoas, de contatos, de universos diferentes. Eu aprendi muito com isso. Desde que entrei, viajei já o país inteiro, conhecendo gente do CMI do país inteiro, desde do Rio Grande do Sul até do Amazonas, Goiânia, Salvador, todo lugar. E gente de fora, um pessoal da Espanha passou três meses aqui... A gente aprende muito com as experiências que eles trazem de lá, as ações, muda até um pouco o nosso foco de atuação. A gente para para refletir, por exemplo, que estamos pondo uma energia muito grande em determinada coisa, e que de repente dá para por uma energia menor de outro jeito. O mais rico mesmo é você ter uma rede internacional de pessoas com uma ideia, que é anticapitalista e autônoma. Isso é o mais interessante, e que está fazendo funcionar uma coisa que a priori muita gente acha que é utópico, inalcançável, haver uma rede no mundo inteiro de produtores de mídia voluntários, e que não estão fazendo para uma ONG, não estão promovendo nada, nenhum Estado, nenhuma instituição. O retorno é para a própria comunidade, não para uma pessoa, etc.

\section{E o que você acha que ainda precisa melhorar?}

Ah, tem muita coisa. Primeiro de tudo, mais gente. Para funcionar, essa rede precisa de gente, com as mais diferentes habilidades, conhecimentos, experiências de vida, luta, sabe, é isso que faz o CMI funcionar, ir para frente. E ser inovador, realizar projetos em diferentes áreas. Uma coisa que desde o começo a gente tenta é não fazer trabalho só na internet, mas a tendência é a gente sempre acabar caindo e se dedicando muito às coisas da internet, então este é um trabalho constante que tem que ter. Pensar 
em sair da internet porque, principalmente se a gente pensar no Brasil, ainda é muito restrito o acesso à internet. Em São Paulo a realidade é uma, mas se você sair de São Paulo é muito pouca gente com acesso, ou que tem, mas com uma banda pequena. Então, promover outros meios é essencial. No Brasil falta muito ainda, até por questão econômica. “Ah , a gente podia fazer uma rádio”. É lógico que a gente podia fazer uma rádio, só que o equipamento é muito caro para ser aprendido em uma rádio por mês. Que é a questão também da criminalização [dos movimentos sociais].

Outra questão essencial para o CMI Brasil, não estou falando da Rede Indymedia, é a reformulação do site, que é uma coisa com que a gente já está trabalhando faz anos, e infelizmente leva muito tempo, porque a gente é voluntário, é um trampo de formiguinha. Se a gente fosse uma mega-corporação, em um mês a gente refazia o site, mas não é a ideia. E fora refazer o site, tem toda discussão por trás do site: como a gente vai disponibilizar a informação, para quem, de que jeito. $\mathrm{Na}$ verdade, em tudo isso tem uma discussão política.

\section{É por isso que demora mais?}

Claro, porque como você disponibiliza isso é político. Se você privilegia a informação de São Paulo, isso é uma posição política. Então temos que tentar fazer com que tudo isso reflita os nossos posicionamentos políticos, o site em si, a ferramenta.

\section{Já está em discussão?}

Já está em discussão faz três anos, e acho que teve um avanço muito grande nos últimos seis meses. Decidimos fazer em outra ferramenta, que é uma ferramenta mais popular, digamos assim, na questão de administração, desenvolvimento e programação do site. É uma ferramenta mais popular, que tem uma comunidade muito grande, e nesses últimos meses a gente está tendo uma ajuda também. Gente que nem é do CMI, e ficou sabendo, está se oferecendo, o pessoal da própria comunidade do Drupal está entrando no chat do CMI para conversar com a gente, dando dicas preciosas, estão à disposição também para ajudar a gente. Quer dizer, isso é fantástico, e ainda falta agregar gente um pouco.

E que o que teria que ser feito, que iniciativa teria que ser tomada pelas pessoas do CMI para isso melhorar? 
Uma coisa é que, como tem pouca gente, os tempos são mais lentos, e isso num momento me angustiou mais. Hoje em dia não me angustia, prefiro pensar que é um tempo que a gente tem que ter: se tiver mais gente vai mais rápido, se não tiver, vamos no nosso tempo. Mas vamos fazer, a gente, com ferramenta livre, do jeito que a gente acredita que tem que ser. As discussões quanto ao site, por exemplo, são muitas, mas acho que é importante este tempo. Outras coisas?

Se tem alguma atitude que é um erro, que pode fazer as pessoas deixarem de entrar mais...

Acho que tem, bastante coisa. Faz tempo, por exemplo que a gente não se dedica a levar o CMI para outros lugares. Tinha uma época em que a gente participava muito de várias atividades para falar do CMI, apresentar o CMI. Hoje, como são poucas pessoas, a gente tem um pouco de preguiça disso, ou até falta tempo, porque está tendo que se dedicar a outras coisas. Mas acho que é um processo natural que, quando as pessoas entram no CMI, elas se dedicam muito. Aí elas começam a ter contatos com vários grupos de que não tinham conhecimento, e acabam encontrando alguns grupos de mais afinidade, e se dedicando mais a estes grupos. Algumas vezes elas se afastam totalmente do CMI, outras não, mas o tempo de dedicação ao CMI acaba diminuindo um pouco. Por um lado é ruim porque a gente tem menos tempo de dedicação desses voluntários para o CMI, mas ao mesmo tempo é muito bom, porque essas pessoas estão atuando em outros grupos, estão tendo um acúmulo de outros conhecimentos, que acabam trazendo para o CMI, sendo ou não voluntário. Uma pessoa, por exemplo, entra no CMI, e depois vai para o movimento GLBT. Até sai do CMI, mas entra no site do CMI para publicar as coisas. Então isso também é uma função que a gente espera para o CMI. Essa utilização é o que a gente quer na verdade. Então está sendo legal, pois tem uma diversidade de grupos que utilizam o CMI hoje um pouco em função disso.

A avaliação que eu costumo fazer muito quando as pessoas falam assim: "ah o CMI está defasado, virou um blog" - tem muita crítica quanto a isso - é de que quando o CMI começou, realmente tinha muita gente e era ponta de linha em termos de tecnologia, porque não tinha nenhum site de publicação aberta. Só que nessa época, existia um problema, que era as pessoas serem muito do mesmo grupo no CMI. Então era muita gente, mas eram todos universitários, estudantes, na mesma faixa de idade, militavam nos mesmos movimentos, que eram os movimentos antiglobalização - não 
era tão plural, se pensarmos. Hoje em dia, se olharmos para quem está no CMI, veremos uma diferença bem grande. Não só no coletivo de São Paulo, como em outros coletivos. Está muito mais diversa a participação das pessoas em questão de idade, escolaridade e, principalmente, na questão de atuação e inserção em outros movimentos. Então, se há nove anos atrás estávamos super inseridos na luta antiglobalização, nas ruas, e fazendo muita coisa nessa luta, em outras absolutamente não. Movimento GLBT, movimento de mulheres, movimento de moradia, movimento de população de rua, movimento de catadores...

Estes são separados do movimento antiglobalização, que é uma coisa mais geral, certo?

Sim, são bem separados. Na verdade, houve uma época em que o pessoal ia e fazia mobilização junto, mas não tinha uma articulação muito grande entre estes movimentos. Hoje, tem gente do CMI que participa do Fórum Centro Vivo, do movimento por moradia, do movimento GLBT, da Biroska ${ }^{29}$, assim, "ene”. Então o pessoal que está no CMI é muito atuante em outros movimentos. O CMI conseguiu se capilarizar dentro dos movimentos sociais. Até pode ter movimento que não tem gente que faz parte do CMI, mas aquele movimento conhece o CMI, já o utilizou ou utiliza, coisa que há nove anos atrás não rolava. Então, se por um lado antes o pessoal do CMI estava na ponta de linha da tecnologia, gastava um bom tempo nisso, e tinha muita gente atuando em um movimento só, hoje estas pessoas estão inseridas e outros movimentos, e não têm mais tanto tempo de dedicação ao CMI como era antes, mas estão trazendo estas coisas para o CMI.

Então você faz uma análise contrária à das pessoas que acham que o CMI está de certo modo "decadente"?

Não acho, para mim, de certo modo o CMI teve um ganho muito grande nestes últimos anos e quem não enxerga é porque não quer ver. A ponto de a gente fazer nosso encontro de 2007 numa base do MST lá em Brasília. Fomos numa ocupação e fizemos nossa reunião nacional lá dentro, coisa que seria inimaginável antes. Quando temos problemas jurídicos recebemos ajuda de advogados de diversos lugares, sabe?

\footnotetext{
${ }^{29}$ Projeto de servidor (ou "servidora", como chamado) mantido por um grupo de mulheres, em que procuram "se juntar desenvolver, aprender, compartilhar seus talentos e conhecimentos ao mesmo tempo que podem apoiar outros projetos relacionados com a questão de gênero e tecnologia". (http://docs.birosca.org/wiki/projeto. Acesso em 13/02/2010)
} 
O que eu vejo então é um grande ganho. Sinceramente, a crítica para o CMI antes era que seria um bando de burguesinhos da USP e dá PUC que estavam ali fazendo isso, pessoal só de universidade, e que daí é muito fácil, etc. Hoje não, essa crítica corremos atrás [de superar].

\section{Integrar-se mais?}

Integrar-se com os outros movimentos, com o que está acontecendo na realidade, apresentar mesmo o CMI para essas pessoas, tentar fazer elas usarem. Alguns movimentos se apropriaram, outros não. Outros a gente tenta até hoje conversar, explicar como é que publica. E para o novo site a gente já está pensando nisso também. Por que nem todos os movimentos se apropriaram do CMI? Alguns porque realmente os caras não têm habilidade na internet. E aí é legal, por exemplo, o cibercafé, que a gente teve muito tempo no Ação Educativa, ficou um tempo sem, e agora estamos retomando no Ay Carmela! Esse é um projeto "fora" da internet, que o CMI já faz há muitos anos e é absolutamente importante, tem que ser multiplicado.

\section{Você falou de atuação fora da internet. Dê outros exemplos.}

Por exemplo, mostras de vídeo. No ano passado aconteceu com alguma regularidade durante metade do ano. Isso é fantástico, é um jeito de você estar junto com as pessoas, ter um debate crítico. Você apresenta um vídeo, um audiovisual, que é uma super ferramenta de reflexão, e não precisa de internet. Quer queira, quer não queira, há muita gente que não tem acesso ao cinema, porque é caro. Essa é uma forma de atuação, e uma outra é rádio. Estamos nos empenhando já faz dois anos para conseguir fazer uma rádio, e se tudo der certo vai sair logo. E uma coisa que é fantástica que funcionou durante muitos anos é o CMI na $R u a^{30}$. Era regra, todo mês tinha CMI na Rua. Todo mês saía gente para pregar, era o encontro da galera mensal: sair para colar o CMI na Rua. Então foi uma produção muito intensa durante anos, e se tudo der certo, a gente retoma.

\section{Agora está saindo, mas sem periodicidade...}

É, sem periodicidade, mas já começou de novo, e o fato de ter o Ay Carmela! ali no centro vai acabar colaborando, tanto para ter um lugar para produzir, quanto

\footnotetext{
${ }^{30}$ Ver Anexos 2 e 3. Mais sobre os impressos produzidos pelo CMI também pode ser encontrado em http://www.midiaindependente.org/pt/blue/static/impressos.shtml. Acesso em 03/03/2010.
} 
para ter um lugar para se reunir e sair, cada um colar, e tal. O Ay Carmela! está sendo um lugar que é nosso, a gente tem a chave, faz programação, e a gente também tem que se preocupar em manter, pagar as contas, tudo. Esse primeiro ano todo mundo teve que se dedicar muito, porque leva tempo para você ter um espaço social, um espaço comunitário, porque não tem jeito mesmo. Tem que todo mundo conhecer, começar a colaborar, ter consciência de sua própria responsabilidade dentro do espaço. Agora que está começando a caminhar para uma coisa que a gente não vai precisar ficar tanto em cima de fazer dinheiro, e se dedicar mais a fazer coisas lá dentro, coisas legais. Esse ano [2010] acho que vai ser muito especial para o CMI ali dentro e para os outros grupos também.

Dentro destes movimentos que os participantes do CMI fazem parte, ou que estão conectados de alguma forma ao CMI, você tem mais afinidade com algum?

Com um não, com muitos. Eu atuo em muitos, colaboro em muitos mesmo. Tem o Fórum Centro Vivo ${ }^{31}$, que eu fui muito ativa durante muitos anos, ao mesmo tempo com o CMI, e hoje eu estou um pouco afastada. Conheci o movimento através do CMI, de coberturas e atos no centro, e aí comecei a frequentar as reuniões, me envolvi, dei uma super força no site... Agora estou um pouco mais afastada porque não dá tempo, é muito coisa. Estou tentando ir mais certeira, pegar umas coisas e meter a cabeça só nelas, sabe. Mas sou apoiadora do Fórum Centro Vivo, vou sempre ajudar, estou sempre junto. Tem a Rádio Livre, que conheci através do Centro de Mídia Independente, e participei, participo...

\section{O que é?}

Como é que pode definir o que é a Rádio Livre? É um movimento?

Drebs: É um aglomerado.

Foz: É um aglomerado. São pessoas que lutam...

Drebs: Convergência.

\footnotetext{
${ }^{31}$ Grupo que articula "pessoas que lutam pelo direito de permanecer no Centro e transformá-lo num lugar melhor e mais democrático, contrapondo-se, assim, ao processo de renovação urbana e exclusão que vem ocorrendo em São Paulo". http://www.centrovivo.org/historia. Acesso em 03/04/2010.
} 
Foz: Uma convergência! Convergência é bom. Tem uma lista da Rádio Livre que está bem paradinha, mas vira e mexe tem uma reunião em algum lugar do país, para tentar discutir alguma coisa, e acaba virando mais festa do que discussão [risos]. Mas Rádio Livre tem um pouco esta característica. E foi pelo CMI que eu conheci. A Rádio Livre vai muito de encontro ao que eu penso, sobre comunicação livre, acho que isso é uma das coisas que materializam o que eu penso, uma das coisas concretas. Tem a Biroska que também é um grupo de mulheres, que têm um servidor com software livre, e a ideia é ensinar as meninas que fazem parte deste grupo a usar software livre, admnistrando um servidor de internet, que abriga sites não comerciais, que vão de encontro com o que a gente acredita.

\section{No CMI especificamente o que você faz?}

Nossa, eu faço muita coisa. Eu participo da lista editorial, sou uma das pessoas que têm uma "nóia" de ficar de olho na coluna da direita, então todos os dias quando acordo, geralmente a primeira coisa que eu faço no dia é ver a coluna da direta, tudo que foi publicado e ver se tem alguma publicação fora da política editorial, para evitar de ficarmos sustentando matérias que vão exatamente contra o que a gente quer. $\mathrm{Na}$ lista editorial também, estou sempre propondo editorial...

\section{Que você mesma escreve?}

$\mathrm{Eu}$ escrevo. Ultimamente eu tenho escrito pouco, porque eu estava viajando, mas eu sempre fui de propor muita coisa, e muita coisa que eu trazia do Fórum Centro Vivo. Porque como o Fórum Centro Vivo é uma convergência de grupos e movimentos sociais do centro, toda semana tinha muita coisa nova: um despejo, alguma questão relativa aos moradores de rua ou aos camelôs... Então eu chegava na reunião lá, conversava com as pessoas, e já tinha muito material para subir no site. Era bem interessante, vinha muito editorial de lá.

\section{E cobertura?}

Cobertura no CMI São Paulo eu fiz dois anos, especificamente vídeo. Em 2004 e 2005 eu fiz muito vídeo para o CMI. Mas depois eu fui fazendo muito isso profissionalmente e fui deixando de fazer isso dentro do CMI por uma questão de estar cansada já de ficar gravando e editando, então quando eu estava no CMI queria 
fazer outra coisa. Fiz muito CMI na Rua, diagramação, texto... E colagem, muito mesmo. O CMI na Rua foi uma coisa que me dediquei, e sempre quando tem eu curto muito, eu vou feliz, adoro sair na rua. Já fui também em muitos encontros - talvez isso seja até uma coisa que a gente deva retomar e seja um problema do CMI, aquela pergunta que você tinha feito, sobre coisas que podem melhorar. A gente tinha muita preocupação em formar as pessoas, então sempre tinha muita oficina no CMI, quando eu entrei, de 2003 a 2005, tinha muita mesmo. Oficina de tudo: quem queria aprender qualquer coisa que não sabia, sempre tinha gente disposta a ensinar, e era muito legal. Desde mexer no Open Office ${ }^{32}$, a diagramar um CMI na Rua, editar um vídeo, publicar uma foto na internet... Tudo. Sobre tudo o pessoal dava muita oficina o tempo inteiro, tinha essa preocupação. E eu já falei várias vezes que eu acho essa uma falha do CMI, a gente tem que correr atrás, e um dos resultados disso é o curso de Linux que vai começar depois do carnaval. Então já é um pouco pensando nisso. Formar as pessoas ao nosso redor, tanto para colaborar com o CMI quanto para a própria vida.

\section{E o que você mais gosta de fazer?}

Gosto bastante de diagramar, fazer cartaz, fazer vídeo também, quando estou menos cansada. E gosto muito de confraternização, momentos de encontro, de troca de conteúdo, informação e conhecimento. Sempre que tem oficina eu adoro: eu adoro ver as pessoas interessadas, eu adoro aprender coisas e eu adoro ensinar coisas. Esse ano tivemos alguns eventos assim no $A y$, como a oficina "Faça você mesmo".

\section{Conte algum episódio que te marcou no CMI.}

São muitos. A cobertura que rolou dos movimentos de moradia em 2004 e 2005, sem dúvida, foi um tesão. Tanto o movimento estava super ativo, quanto a gente estava muito articulado, daí nestes dois anos aconteceram muitas coisas. Havia muita violência por parte da polícia, então a gente tinha que ter estratégia. A gente armava esquema com advogado, caso alguém fosse preso. A gente montava uma base, que era a casa de alguém, para onde as pessoas podiam ligar a cobrar durante a noite para contar o que ia acontecendo, e a pessoa ia publicando. Vídeo, a gente passava a madrugada editando para depois estar online logo de manhã... Isso tudo sempre foi muito legal. Acho que todas as reuniões nacionais que eu participei foram marcos,

\footnotetext{
${ }^{32}$ Conjunto de softwares livres de edição de textos, planilhas e imagens.
} 
tanto por conhecer pessoas de outros lugares e suas realidades quanto por aproveitar a experiência do CMI de outros lugares.

A gente fez muita ação. Eu gostava da época que o CMI bancava fazer as ações. Mudança de nome da Avenida Roberto Marinho para Vladmir Herzog. Foi fantástico. Teve uma vez que a gente fez um protesto num evento da Microsoft no Conjunto Nacional. Distribuímos panfletinho sobre Linux... coisinhas pequenas, que marcaram. Teve eventos em outras cidades que foram muito marcantes também, por exemplo, no Sonho Real ${ }^{33}$.

O que mais? Bem, a morte do $\mathrm{Brad}^{34}$, acho que o pessoal aqui no Brasil ficou meio amortizado, foi muito forte. Ele ficou muito tempo aqui no Brasil, e ficou muito próximo de todo mundo.

Outros momentos também foram sequestros de servidores, todos eles foram muito fortes. Isso tem a parte ruim que é essa ação de violência do Estado, mas também quer dizer que a gente está incomodando, é prova que estamos incomodando e sendo reprimidos. Então a repressão é real. Muita gente fica falando que não existe, que isso é da nossa cabeça, que a gente que é radical e não sei o quê. Mais pessoas mais velhas ou que não são do meio dizem: imagina, vocês estão viajando, não existe isso... e a hora que você mostra um evento destes fica bem palpável.

Drebs: Mas na ditadura era pior!

Foz: [risos] É, isso é uma coisa que sempre que a gente discute aparece, e isso causa um conformismo nas pessoas hoje em dia. Eu realmente não acho que na ditadura era pior, eu não acho que estava tendo menos morte que hoje em dia.

Drebs: E quem fala isso é de classe mais alta.

Foz: Se você for em diversos locais, tem pessoas morrendo. Não tem permissão nem para eles irem, a gente sabe, não precisa ir distante. Qualquer periferia, mulher depois de onze da noite não pode circular. Você vai no Rio de Janeiro, o pessoal nos morros não pode circular. Então espera aí, que democracia é essa, para

\footnotetext{
${ }^{33}$ Despejo de ocupação por famílias no Parque Oeste Industrial em Goiânia (GO), em 2004.

${ }^{34}$ Voluntário da Rede Indymedia morto com um tiro durante cobertura de vídeo da rebelião popular em Oaxaca, no México, em 2006.
} 
quem? Está funcionando mesmo, está melhor do que na ditadura? Não sei, eu tenho mesmo minhas dúvidas.

\section{Politicamente você se define como, se é que você se define?}

$\mathrm{Eu}$ não me defino não. Eu gosto muito das ideias anarquistas, até frequento alguns grupos anarquistas, mas tenho resistência em falar que sou anarquista. Acho que sou mais autonomista do que anarquista. Mas como eu acho meio burro se autodefinir... Você não precisa se autodefinir.

Sobre a relação da tecnologia com a comunicação nos movimentos sociais: você acha que as coisas estão mais fáceis agora para quem se envolve com ativismo?

Eu acho que sim. Tem uma parte da tecnologia que está bem mais acessível. Celular com câmera de foto e vídeo, isso é uma coisa que seria inimaginável há dois, três anos atrás. O movimento nacional de população de rua ter câmera fotográfica não era uma coisa que rolava, e hoje já tem, já tem bastante. Só que ainda tem um problema de acessibilidade. Por exemplo, você tira foto, como disponibilizar isso? Aí o cara sabe mandar em email, mas daí manda um email muito grande e ninguém abre, ou lota a caixa. Ainda têm algumas coisas que não estão sendo usadas com praticidade pelos movimentos sociais. E acho que a tecnologia que eles têm nas mãos hoje daria para fazer muita coisa que ainda não é feita.

Drebs: E também 65\% dos brasileiros nunca acessou a internet, nem uma vez, o que é uma estatística muito alta. Todo mundo tem celular, todo mundo tem câmera, mas $65 \%$ nunca acessaram a internet. É esquisito, aqui no centro da cidade a gente não consegue imaginar isso, fica mais longe. É muito concentrado, e a gente não consegue ter a dimensão dessas pessoas.

Foz: É verdade. A pessoa tira uma foto e vai por aonde? Não tem um jornal próprio, não tem acesso à internet. Tem um acesso à tecnologia, mas não é total. Quando tem foto não tem internet, quando tem internet não sabe escrever, quando sabe escrever não sabe gravar um áudio, quando sabe gravar não sabe onde disponibilizar... 
Se o acesso é o problema, supondo que o acesso fosse bem democratizado, você acha que resolveria bastante?

Eu já vejo muita mudança de 2003 para hoje, nestes movimentos que eu atuo mais aqui no centro de São Paulo, que de certa maneira têm um pouco mais de acesso que outros movimentos em periferias, cidades menores ou distantes. Eu já vejo uma melhora bem grande até em coisa de mandar texto por email. "Gente, ontem mataram um morador de rua, o nome dele era Fulano de Tal, foi assim, assim, assado..." Coisa que nem existia em 2003, a galera não fazia isso. Então, em coisas simples você vê uma evolução. Quando eles têm um espaço comum como o Ay Carmela!, com computador, com acesso à internet... Você vê como isso vai melhorando. Só que este é um trabalho de formiguinha, não têm um impacto muito grande, se você for pensar: "Nossa, mas isso muda todos os movimentos?” Não, é bem pouquinho.

E isso que você falou, de quando o acesso for bem democrático, não vai ser bem democrático, sabe? É só pegar o que o governo está fazendo agora, de acesso à internet pelas empresas, é ridículo. Não é para ter acesso para todos. O próprio governo podia dar acesso, mas o lobby por trás é muito maior. Se for aprovada a Lei Azeredo nem será possível as poucas cidades que fazem isso hoje darem acesso gratuito. Logo se vê que não há uma vontade de democratização. Por que é que rádio de pequena potência não pode? Não faz sentido nenhum, e não pode. Então não existe uma vontade política de democratizar a comunicação. Quando tem, tem ONG que vai ser o intermediador para a coisa acontecer, e isso não é democratizar. Você depender de um intermediador para a pessoa poder ter acesso à internet enquanto aquela ONG estiver a fim não é uma solução.

\section{Como você nomearia o site do CMI, é um veículo jornalístico?}

As pessoas têm aquela coisa de dizer que o CMI é um blog, que virou um blog, quando na verdade ele já existia antes dos $b \log s$, e talvez existam hoje muitos blogs espelhados na experiência do CMI com publicação aberta. Qual é o diferencial do CMI então? Para mim é muito claro: é um local de publicação aberta que garante segurança para quem está publicando. Se não é contra nossa política editorial, a pessoa tem a segurança de não ser identificada, não ser rastreada, e de que aquela matéria não vai sair do ar por besteira. Que outro lugar na internet você pode fazer denúncia com segurança? Não existe. Existem outros sites de comunicação, de esquerda, existem outras linhas - e eu acho ótimo, tem que ter o máximo de 
comunicação de esquerda possível, um mais comunista, outro mais socialista, anarquista, não importa, tem que ter vários tipos de linguagens. O CMI também faz este papel, mas acho que o principal papel que muita gente insiste em ignorar e não enxergar é que é um site em português para as pessoas fazerem denúncias com segurança, tanto de a pessoa não ser rastreada, quanto da matéria dela estar ali no ar. Então a pessoa que publica sabe que, se não foi contra a política editorial, ela [ $a$ matéria] vai ficar online. E a coisa de não ter uma pré-avaliação: você publicar, esperar alguém avaliar e depois liberar. O processo do CMI é o contrário: por princípio está lá, e isso é uma grande diferença.

\section{Quando você fala "denúncia”, você vê isso como jornalismo?}

Vejo. Tem muita coisa jornalística lá e muitas coisas que não são jornalísticas, mas que são muito importantes. Desde quando entrei no CMI achei muito importante que todo mundo tem propriedade para falar sobre sua própria vida. Isso tira um pouco esse poder do jornalista de criar uma realidade estando quinze minutos em um lugar acho isso bem complicado. Então aconteceu uma desgraça no Jardim Pantanal. O jornalista vai lá, e em quinze minutos conversa com três pessoas, transforma aquilo na realidade do lugar, e pronto, acabou. Isso é ridículo, acho isso bem deficitário no jornalismo.

\section{Mas a própria população já faz uso do CMI?}

Alguns sim. Do Jardim Pantanal tivemos um monte de publicação, e foi muito legal.

\section{Sem o intermediário?}

Sem o intermediário. Na verdade eles fizeram não só pelo CMI, mandaram para um monte de gente por email, mas também publicaram no CMI. Desde que eu entrei no CMI é isso que eu quero, que as pessoas falem por si só. Realmente existe uma política de fazer as pessoas cada vez falarem menos, cada vez se pronunciarem menos. E o CMI tem esta proposta: todo mundo é jornalista, não tem que ter uma faculdade para ser jornalista. Porque da sua realidade, quem sabe falar é você. 


\section{Você fez curso de jornalismo, formou-se?}

Sim, me formei para nunca trabalhar na área, profissionalmente. Na verdade o curso de jornalismo me estragou, porque eu entrei escrevendo loucamente e saí sem escrever uma palavra. Porque o que me falaram em quatro anos de faculdade foi como escrever dentro das normas do veículo em que você está trabalhando. Simplesmente me tirou todo o tesão de escrever, tudo que eu gostava de fazer, inventar linguagens... Foi por água abaixo. Então, acho super desanimador, nunca recomendo ninguém a fazer jornalismo.

\section{E quando você escreve para o CMI, como que é isso?}

Quando eu escrevo para o CMI é conversando com as pessoas, eu sempre estou conversando, pego o que elas estão falando... Ultimamente eu mais encaminho do que proponho, sabe, porque acho que o que elas escreverem já está ótimo. Nem me sinto mais muito à vontade para falar dos outros; quando eu falo é sobre coisa relativa ao que eu estou passando. Prefiro escrever sobre coisas de que eu participo e encaminhar propostas de outras pessoas. Como eu leio muito a coluna da direita do CMI, eu falo "olha gente o que publicaram aqui, vamos colocar como editorial?” Faço muito isso. Às vezes procuro um link, uma imagem para colocar, dou uma organizada.

Falando dos veículos de mídia convencionais. Você acha que dentro do modelo deles não há nenhuma saída para os problemas da mídia que o CMI critica?

Não acredito, porque o modelo de eles estarem submetidos à viabilidade econômica... Eu não acredito em jornalismo como comércio, e no conhecimento como uma moeda. É exatamente o que eu não quero, e o jornalismo hoje em dia está todo pautado nisso. São os interesses econômicos e políticos de quem domina aquele meio. Eu desconheço qualquer grande veículo aqui no Brasil que seja autônomo e independente. O mais próximo disso é o CMI.

Mas você falou que acha importante ter vários tipos de atuações diferentes, fora do que o CMI trabalha, com outras propostas, tipo ONG...

Não acho que o CMI tenha que trabalhar com ONG. E mesmo jornalismo, em ONG, acho que está errado. Falta requestionar o que é jornalismo no Brasil, e jornalismo no Brasil é comércio. 
Drebs: E ONG é comércio.

Foz: E ONG é comércio. Então não tem jeito, não tem jeito. Jornalismo é conhecimento, e conhecimento não pode ser uma moeda, se é uma moeda, já está errado, já tem interesse de alguém no meio. Então para o jornalismo ser o que ele se propõe a ser, que é essa coisa de alastrar o conhecimento, não dá para ser com interesse econômico e político por trás. E as pessoas não têm nem ideia que tem estes interesses por trás, ou que o enredo da novela é feito para satisfazer o interesse de alguém.

Drebs: Eu perguntei para minha mãe hoje se, já que as novelas vendem espaço de merchandising para produtos como Nívea, Natura, ela não achava que elas podiam vender também o enredo. E ela falou que ela acha que não, que ele vem da cabeça do autor da novela, da criatividade do autor da novela. Ela não acha que o enredo da novela possa ser um produto. Só que a novela está falando sobre construção de moradia popular em cima da Galeria do Rock, não sei se você está acompanhando...

Foz: Especulação imobiliária.

Drebs: Tem um cara, que é dono da galeria, que quer derrubá-la para construir moradia popular, e as pessoas não querem. Então tem a ver com a ocupação do centro.

\section{Tem isso na novela?}

Foz: Tem, juro, é de ficar abismado.

Drebs: E a novela passa agora no ônibus, não sei se você tem acompanhado. Bus Media...

\section{Passa novela?}

Foz: Passa novela! O resumo da novela do dia anterior.

Drebs: Com legendas. Às vezes tem o Globo Esporte, Vídeo Show... tudo que é programação da Globo. 
Foz: Um absurdo... Mas é isso. Assim, realmente, acho que as pessoas não têm noção do que está por trás. Não têm noção de que quando o Jornal da Globo mostra que os sem-terra derrubaram pés de laranja... São mil pés de laranja de uma fazenda com um milhão de pés.

Drebs: É menos do que um terço de um por cento. Tudo bem, são mil árvores, é uma questão a se pensar, mas compara, sabe...

Foz: E daí a mídia vai lá e faz uma outra realidade. Ninguém fala que aquela terra era grilada, um monte de coisa. $\mathrm{Na}$ verdade, as pessoas não têm uma reflexão diária sobre as coisas.

Drebs: Tem um vídeo aqui [na internet] do Boris Casoy falando do MST...

Foz: É incompatível, sabe, jornalismo é incompatível com o comércio. Enquanto tiver comércio no meio, tem interesse de alguém, que vai deturpar. E quem está escrevendo vai ter o poder. Quem está lendo vai ser apenas uma pessoa que lê, ela não vai ter interlocução com quem está fazendo... No CMI não rola isso: se alguém vê uma matéria, um editorial, e quer debatê-lo, mostrando um ponto que é válido, a gente muda o editorial. Para para pensar e reflete. Se a gente vê que a gente fez merda, a gente muda, não tem problema. Isso não existe no jornalismo da grande mídia, no jornalismo corporativo. A comunicação corporativa, de uma maneira geral, é o receptor e o emissor e pronto. O que a gente está fazendo no CMI é quebrar isso: todo mundo é emissor e todo mundo é receptor. E desde que entrei no CMI conversamos sobre isso, sobre fazer as pessoas acreditarem nisso, que hoje, é a coisa mais difícil. Porque elas acreditam que aquela pessoa que está falando no Jornal Nacional é quem tem capacidade de falar, e o resto não tem. É isso que os meios de comunicação fazem com as pessoas, que elas acreditem que não têm capacidade, conhecimento, estudo suficiente, que não são bonitas... Porque acaba envolvendo um monte de coisa, né? Então o que o CMI quer é que as pessoas acreditem nelas mesmas, que elas podem ser os comunicadores, terem a voz delas, falarem o que as aflige. 


\section{Bem, é isso, quer acrescentar mais alguma coisa?}

O site novo vai dar um gás legal, desde coisinhas como a mudança de "comente esta matéria" para "acrescente a esta matéria". Sabe estas discussões bobas que saem do foco do que está escrito? Isso é uma coisa que discutimos muito tempo e já está começando a mudar. A gente vai soltar um editorial quando terminar, falando o porquê desta mudança. Queremos que fique uma coisa mais de aprofundar a matéria postada em vez de um debate em que às vezes ficam duas pessoas brigando... A navegação também vai ser bem diferente, para as pessoas poderem filtrar por assunto. Haverá uma conta para salvar pastas com matérias preferidas por assunto... Várias coisas.

\section{Drebs quer falar alguma coisa?}

Drebs: Não... Eu endosso tudo que ela falou... [risos].

\section{Você também faz parte do CMI faz tempo?}

Desde 2007.

\section{Você trabalha com o que lá?}

Eu faço mais a parte técnica. Atualmente eu quero me envolver um pouco mais com o coletivo de São Paulo, mas meu trabalho tem sido mais virtual, ajudando a manter toda a infra-estrutura que o CMI precisa.

\section{E o que você mais gosta no CMI?}

O que eu mais gosto? É um lugar em que eu me sinto muito à vontade de trabalhar. A gente estava vendo hoje, no site da Canonical, que é a empresa que faz o Linux Ubuntu. Ela está contratando pessoas, e tem uma frase em que eles dizem o que querem de quem vai trabalhar, e é exatamente o que a gente quer de quem vai trabalhar no CMI, só que em outro sentido... "Habilidade de ser produtivo num time distribuído globalmente, através da autodisciplina e automotivação." Só que neste caso eles vão pagar também né... [risos] Mas é bem isso, automotivação, para você estar trabalhando com pessoas com quem divide ideias em comum, topa conversar sobre isso, a construção é horizontal, não tem cobrança, só tem agregação. 


\section{Você era do movimento de Software Livre? Como você foi parar lá?}

Não, meu lance era movimento estudantil antes, e Rádio Livre também. E aí teve a ocupação da Reitoria da USP, em 2007, e eu conheci mais algumas pessoas... Eu já conhecia o CMI e conheci pessoas do coletivo. Eu já conhecia algumas, mas daí me chamaram e eu entrei e comecei.

\section{Toya}

Outra voluntária que participou da montagem de um coletivo da Rede Indymedia no Brasil, Toya contou um pouco desta história e da sua própria, durante toda a vida envolvida com movimentos sociais, atualmente principalmente os da América Latina, mesmo que morando nos Estados Unidos. Toya faz parte do coletivo técnico e conta que praticamente todos os dias realiza algum trabalho para o CMI. Ela destaca que o CMI Brasil, entre outras particularidades, foi um dos primeiros a adotar o uso generalizado de softwares livres, em uma época em que o assunto ainda não era tão conhecido como atualmente. Ressalta também os momentos em que a atuação do coletivo promove o que ela chama de uma verdadeira "guerrilha midiática". Comentou ainda os resultados de uma análise estatística ${ }^{35}$ que ela realizou das postagens no site CMI Brasil desde sua a criação, e afirmou que acredita que esteja havendo uma maior conscientização das pessoas em relação a uma postura crítica diante das informações divulgadas pela grande mídia.

\section{Primeiro eu queria que você contasse um pouco do seu histórico no CMI,} você foi uma das pessoas que trouxe o CMI para o Brasil, não foi?

Isso. Em 2000 eu estava aqui nos Estados Unidos, em julho, e na época eu entrei em contato com o Pablo e ele me passou o endereço do Indymedia para eu dar uma olhada porque eu estava buscando contato com alguns grupos do movimento antiglobalização aqui nos Estados Unidos.

Eu fui para a Filadélfia, porque ia ter uma manifestação contra o lançamento da candidatura do Bush para a presidência, e lá eu conheci o CMI Filadélfia, que estava cobrindo as manifestações. Eles tinham um jornal diário, uma rádio, depois eu conheci o pessoal de Nova York, e quando eu voltei para o Brasil a gente estava formando a Ação Global dos Povos e conversando com o Pablo, que eu só conhecia

\footnotetext{
${ }^{35}$ Capítulo 2, Tab. 2.1 e Fig. 2.1
} 
por email. A gente lançou um chamado na lista de Ação Global e, a partir daí, fez a primeira reunião e começou a trabalhar no site.

\section{Como você começou a se envolver com o ativismo, antes do CMI?}

Minha família sempre foi, e meu pai é marxista. Sempre teve uma tendência de esquerda e, de 98 até 2000, eu morei no sul de Minas, em Alfenas, onde tive um contato muito próximo com o Movimento dos Sem-Terra. Ali na região de Alfenas tem alguns acampamentos e assentamentos, e eu trabalhava muito com ele e depois com o movimento anarquista. Daí aconteceu a manifestação em Seattle que chamou a atenção de todo mundo.

Daí para frente eu vi que estava tendo essa organização da AGP no Brasil, e queria apoiá-la. Já participava de alguns coletivos de defesa dos direitos dos animais, também. Então foi a partir daí, e um pouco trabalhando com o MST e também com alguns grupos autônomos. E depois, quando começou a AGP, a gente começou a trabalhar em uma campanha contra a ALCA no Brasil.

E aí você foi fazendo esses contatos com essas pessoas que estavam envolvidas com os movimentos de antiglobalização e resolveram formar um CMI aqui também.

Isso, daí a gente teve a primeira reunião em São Paulo. Na época minha irmã já morava em São Paulo, porque eu sou de Minas. Aí eu voltei dos Estados Unidos, fui para São Paulo participar das reuniões, já começar a organizar a manifestação que a gente estava planejando em abril contra a ALCA. E em dezembro lançamos o site.

Em dezembro eu estava com a minha família em Belo Horizonte por causa do final do ano. Um coletivo de que eu fazia parte organizou um dia sem compras, que é um dia antes do Natal, contra o consumismo, e a primeira matéria postada no site foi dessa manifestação que aconteceu em Belo Horizonte, e que eu publiquei. Então, desde o começo eu estava junto com o pessoal organizando tudo.

\section{E desde essa época você fica um tempo aqui no Brasil, e vai para os Estados} Unidos, ou você está aí morando mesmo?

Eu estou aqui, o meu marido é daqui então eu estou aqui desde dezembro de 2006, mas a nossa ideia é voltar e morar no Brasil. Depois que a gente montou o CMI, no final de 2000, a gente foi para o Fórum Social Mundial, em janeiro de 2001, onde a 
gente teve contato com outros voluntários de outros CMIs, que também foram para o Fórum de Seattle, do Canadá, e o pessoal da rede global. Porque a rede estava crescendo e de uma forma não muito organizada. Praticamente onde tinha uma manifestação formava um coletivo... E a gente já vinha discutindo sobre a organização da rede. Foi chamada uma reunião para o final de abril de 2001 que seria uma reunião global aqui em São Francisco, e eu fui a pessoa que veio para representar o Brasil. E foi nessa reunião que a gente criou toda a estrutura da rede global, mais oficializada. A gente criou processos para novos coletivos, criou a estrutura de comunicação dentro da rede, grupo de trabalho para estar acompanhando os coletivos novos e também teve discussões sobre a comunicação na rede que era praticamente toda em inglês, e isso excluía muita gente. E eu vim para cá em 2001 para poder estar nessa reunião.

Na época o CMI Brasil também estava crescendo. Teve um pessoal do Rio que começou a se envolver e eles fizeram o primeiro documentário do CMI, que foi o A20. Então eu fiquei aqui ainda um tempo fazendo uma turnê com o vídeo, exibindo ele em vários lugares, e depois eu voltei para o Brasil.

Fiquei no Brasil um tempo, entre 2001 e 2003, e foram aparecendo coletivos na América Latina. Teve o coletivo da Argentina, do Uruguai, da Bolívia, e do Chile, que foram se formando. E nessa época a gente teve o primeiro encontro dos coletivos latinos, na Argentina. E depois, em 2003, eu passei seis meses na Argentina trabalhando com o coletivo do CMI Buenos Aires. Depois disso, em 2004, eu fiquei um ano aqui em São Francisco, mas resto do tempo eu fiquei no Brasil. Em 2006 foi que eu voltei para cá.

\section{E nesse período todo no CMI que tipo de trabalho você fez: mais variado ou} se concentrou mais em algum tipo de atuação?

Eu faço parte do coletivo técnico, então a gente faz o trabalho de manter o site, o servidor. O servidor do CMI Brasil também hospeda sites de outros coletivos: a gente hospeda o CMI Venezuela, Chile, Equador. Então eu dou esse apoio técnico para esses coletivos também, mais para a rede latina. Eu participei da rede global até o começo de 2008. Em 2008 eu saí da rede global, mas continuei o meu trabalho com os coletivos da América Latina. Mas até 2008 eu participava da rede global, de vários grupos de trabalho e tudo mais. E no CMI Brasil eu também colaboro com cobertura, publicando artigos, fazendo propostas para o coletivo editorial, para a coluna do meio. 
Também ajudo na manutenção do site, e também na parte de organização da rede Brasil mesmo, e respondo emails que chegam para contatos, esse tipo de coisa.

\section{Quanto tempo você dedica por semana às atividades do CMI?}

Ah, eu dedico todos os dias praticamente, nos últimos dez anos. Praticamente todo dia tem coisa para fazer: quando não é do CMI Brasil, tem alguma coisa com outro coletivo que a gente dá apoio para ir resolvendo, fazendo, mas nos últimos dez anos, praticamente todos os dias eu trabalhei e colaborei fazendo alguma coisa, desde responder emails, propostas, projetos, até estar publicando no site os editoriais aprovados. Todo dia tem alguma coisinha e você acaba dedicando pelo menos duas ou três horas do dia nisso.

\section{Que diferença você vê do coletivo brasileiro em relação aos outros em que} você atuou, ou com que você teve contato?

A rede global é muito diversificada, a gente tem certos princípios da rede global, mas a gente também respeita a autonomia de cada coletivo. Por exemplo, tem coletivos que têm voluntários pagos. O CMI Brasil sempre teve uma posição contra isso, inclusive todos os CMIs da América Latina sempre tiveram essa posição, isso é uma coisa que é diferente. Uma outra coisa que eu acho interessante, é que no CMI, desde o começo, a gente sempre optou pelo software livre, e hoje em dia o software livre está muito mais avançado do que era antigamente. Então, no começo de 2000, de 2001 até 2004 mais ou menos, os softwares livres para produção de mídia ainda estavam em desenvolvimento, e tinha ainda algumas dificuldades, mas a gente sempre apoiou isso, e sempre optou por usar o software livre. Outros coletivos não têm essa preocupação, apesar de ter gente do movimento software livre que faz parte, mas não têm essa preocupação. Por exemplo, na Argentina tinha muitas máquinas no espaço que o CMI utilizava que usava o software proprietário, aqui mesmo, em São Francisco, tem muita gente que é do movimento software livre, mas na oficina, na época, não tinha uma máquina que rodava em software livre, e fomos nós, eu e uma outra pessoa de outro lugar que tomamos a iniciativa de instalar e colocar lá para estar promovendo. E também por ter tomado essa opção de utilizar o software livre as pessoas envolvidas com o CMI acabaram dando um apoio muito grande para o desenvolvimento de certos softwares que hoje em dia são utilizados por diversos grupos na área de mídia, tanto de streamming de vídeo, de áudio ou de edição de 
vídeo, edição de áudio. Os voluntários do CMI começaram a colaborar com esses projetos, o que foi super importante para a evolução deles. Isso eu acho importante: a gente ter tomado essa posição desde o começo e ter apoiado esse movimento do software livre.

Outra coisa que diferencia um pouco é que no Brasil desde o começo a gente sempre optou por compartilhar o mesmo site. Então é uma rede e, por exemplo, aqui nos Estados Unidos, não têm uma rede, cada cidade, estado, tem o seu próprio coletivo, mas eles não trabalham em rede. Então o país inteiro, no Brasil, resolveu se organizar de uma forma mais unida.

Você falou do movimento do Software Livre. Tem algum movimento além do trabalho no CMI onde você atua diretamente?

Tem. Bem, nos últimos anos eu atuei em diversos grupos, dependia um pouco de onde eu estava, de como eu estava trabalhando. Ultimamente eu participo de uma coalizão de vários grupos em solidariedade com a América Latina. A gente está fazendo um trabalho, desde que aconteceu o golpe de Estado em Honduras, de apoio à resistência popular em Honduras, e esse apoio vai de diversas formas: desde de enviar delegações de direitos humanos para o país para fazer relatos, até fazer eventos para arrecadar dinheiro. A gente já enviou mais de cinco mil dólares para o movimento. Também trabalha com outros grupos e movimentos da América Latina. A gente vem trabalhando com o Sindicato dos Eletricistas do México, que teve 44 mil pessoas mandadas embora da noite para o dia, em um processo de privatização. E também há o trabalho com o pessoal na Bolívia, que é um grupo legal, que está movendo um processo contra o ex-presidente da Bolívia, Gonzales Sanchez, que em 2003 tentou privatizar o gás. Teve uma batalha na Bolívia e ocorreu um massacre, morreram mais de vinte pessoas. Então esse grupo legal ainda vem tentando processar o expresidente, e eu venho trabalhando com eles, dou apoio técnico.

Eu faço parte também de um coletivo que se chama Line Feed, que é um coletivo que dá suporte técnico para movimentos sociais da América Latina. Por exemplo, esse coletivo legal da Bolívia, eu fiz o site para eles, eu hospedo o site deles, tudo de forma gratuita e voluntária. Isso também com outros movimentos da América Latina.

Mas eu já participei, apoiei, e trabalhei junto com o movimento de moradia em São Paulo. Já morei um tempo em uma ocupação em São Paulo, trabalhava com as 
famílias lá, e também morei em ocupações em outros lugares, na Argentina, aqui também nos Estados Unidos... Então já atuei bastante no movimento de moradia.

\section{E todos esses movimentos em que você trabalhou tiveram alguma interseção} com o CMI? Vocês usavam o Indymedia para dar algum suporte também ou são coisas separadas?

Não, acaba meio que envolvendo uma coisa com a outra. Em certos momentos você está organizando uma ação, um protesto, você está como movimento. Mas no momento de divulgar as coisas eu acabo publicando no CMI. Então meio que eu acabo saindo um pouco da posição de voluntária do CMI e entrando mais na posição de usuária mesmo. De estar utilizando o site do CMI para divulgar as ações e as propostas dos movimentos de que eu faço parte.

O que mais você valoriza no CMI como um todo e o que você acha que é possível melhorar?

Eu valorizo a publicação aberta e o fato do CMI não ter uma moderação prévia nessa publicação. Porque moderação prévia é, por exemplo, você publicar um comentário e ter que aguardar permissão do moderador para o seu comentário aparecer no site. O que é super normal em todos os sites na web. Então, no CMI não

acontece isso. É uma transparência que tem no processo de manutenção do site. Não tem uma moderação prévia, a gente tem a nossa lista onde a gente discute os artigos que devem ser escondidos ou não, e que é completamente aberta. O que eu mais valorizo é isso, esse processo aberto e a publicação aberta.

O que eu acho que faz falta... Um problema muito forte na rede, por exemplo, é que tem gente que está na rede há bastante tempo e tem gente que está entrando agora. Então passar a história da rede para essas pessoas que estão entrando é sempre muito difícil, a gente tem uma documentação extensa, de todo processo, coisas da rede e tudo mais, mas não é todo mundo que vai sentar e ler tudo aquilo. Uma das coisas mais difíceis é você conseguir passar toda essa bagagem de experiência, de memória, de discussões passadas, de coisas que deram certo, que deram errado, para as pessoas novas. Às vezes isso deixa a pessoa sem estar situada, sem saber como participar e ajudar mais facilmente a rede. Isso precisa ser melhorado, mas é sempre uma questão de vontade própria dos voluntários novos de estarem entendendo melhor a rede de estarem se envolvendo mais. Terem paciência de ler mais as documentações. E 
também envolve a falta de tempo dos voluntários mais antigos que já estão um pouco sobrecarregados com os seus afazeres e às vezes acabam não tendo tempo de passar essas informações para as pessoas novas que estão chegando. Então isso sempre vai ser um problema, essa passagem de informações da pessoa velha para uma pessoa nova.

E nas atividades todas que você me contou, incluindo as atividades no CMI... O que mais te realiza nesse trabalho com o ativismo?

O que mais me realiza é ver o potencial disso tudo. É ver que o CMI está agora para fazer dez anos, saber que a gente conseguiu mantê-lo vivo por uma década já é uma coisa que me realiza, e também saber do potencial que o CMI tem. O CMI é um dos sites de esquerda mais acessados do Brasil. A gente tem um nível de audiência muito grande, e que dá para aumentar, e conseguir estar mais presente na formação de opinião pública.

E também umas coisas pequenas. Tem certas coisas que acontecem no dia-adia que você olha e fala: "essa estrutura que fez isso possível". Quando teve a manifestação em Gênova e teve a repressão, o caso da morte do Carlo Giuliani, o CMI na época tinha o QG dele em uma escola, que foi invadida pela polícia depois, mais para o final das manifestações. Mas durante toda a semana o pessoal que estava nesse lugar estava produzindo, publicando informações, e pessoas espalhadas pelo mundo inteiro estavam acompanhando essa cobertura através do IMC, o chat, bate-papo que a gente tem. Então, por exemplo, saía uma publicação em inglês e era uma coisa traduzida para o português, para o espanhol, para o francês. A cobertura... O pessoal tinha uma rádio online em Gênova, ela era transmitida e re-traduzida em uma outra transmissão na Argentina, então a gente estava em rede. E no momento em que a polícia invadiu a escola, a gente estava ouvindo ao vivo aquilo e acompanhando. As pessoas dizendo pelo bate papo, "olha a polícia está aqui, está acontecendo isso", e a polícia literalmente invadiu, quebrou todos os computadores, mas a cobertura continuou, porque a gente tinha todo esse apoio descentralizado, que estava online acompanhando. O que aconteceu: quem estava na Itália, e não estava na escola, começou a ligar para as pessoas que estavam dentro da escola e pegar a informação do que estava acontecendo. Essas pessoas que estavam no telefone colocavam tudo que era dito para elas no bate-papo, e a gente ia traduzindo e atualizando os sites com aquelas informações. Mesmo a polícia tendo ocupado aquele espaço e impedido o 
trabalho das pessoas, a rede continuou trabalhando e a informação continuou saindo. Em dois segundos a gente já tinha uma outra rádio que estava sendo transmitida, na verdade de Buenos Aires... Transmitindo toda informação do que estava acontecendo dentro da escola, totalmente ocupada pela polícia.

Então você vê em momentos como esse, de uma certa forma, é uma guerrilha midiática, uma estrutura com a qual a gente consegue vencer repressões fortíssimas. Você saber que as pessoas que estão lá dentro sabem que a gente está acompanhando o que está acontecendo com elas e garantindo de uma certa forma que a gente vai informar a população da violação de direitos humanos, da repressão que está acontecendo ali naquele momento com elas.

Outras coisas pequenas: por exemplo, em São Paulo, em 2005, a gente publicava um jornal impresso, para pregar na parede que é chamado CMI na Rua, e teve uma edição que a gente fez sobre a violência contra os vendedores ambulantes. E eles entraram em contato com a gente assim: "Olha, eu vi o jornal, estou entrando em contato porque quero contar a minha história”. É um trabalho que assim, eu estou colando e não tenho a mínima ideia de quem está lendo, e no entanto você vê o resultado, a pessoa está ligando para você para contar a história e te deixa feliz, de ver que está chegando a informação e ver que as pessoas estão querendo ser ativas também, estarem comunicando o que está acontecendo com elas. Então são pequenas coisinhas assim que te deixam contente com o trabalho que você faz, né.

Como você vê o papel da tecnologia nos movimentos sociais hoje? Você acha que melhorou alguma coisa? O desenvolvimento da tecnologia ajuda o ativismo?

$\mathrm{Eu}$ acho que ajuda, claro. Eu acho que a tecnologia faz com que grupos conheçam outros grupos que estão trabalhando na mesma causa e que consigam se organizar em rede, fazer ações, serem solidários uns com os outros. Também ajuda na comunicação, de colocar na web. Hoje em dia é muito mais fácil uma pessoa ter o seu próprio blog, o seu próprio site, isso ajuda bastante. Agora, tem uma falta de acesso a essa tecnologia, por diversas razões, e a questão financeira: não se tem acesso a web, não se tem acesso a computador, ou muitas vezes a pessoa tem esse acesso, mas não tem conhecimento.

E outro ponto que eu acho super legal da formação do CMI é que em todo esse nosso processo de criação da rede nesses dez anos a gente sempre trabalhou nos coletivos entre as pessoas, está sempre compartilhando conhecimentos, sempre 
fazendo oficinas. Eu sei fazer edição de vídeo, e eu vou ensinar para todo mundo que quer aprender a fazer edição de vídeo. E estar fazendo isso com os movimentos sociais também. Tem coletivos que... Por exemplo, em Goiânia, pessoas que estão envolvidas com o CMI, depois do caso do despejo do Sonho Real, começaram a trabalhar direto com o movimento dos sem teto de Goiânia, e que ocupou, até ser despejado, o Sonho Real. Eles vêm trabalhando com eles em oficinas de mídia, ensinando as pessoas a estarem fazendo a sua própria mídia, e esse trabalho já teve resultados excelentes. Todos os filmes que eles produziram ganharam prêmios em Brasília, ganharam um valor alto de dinheiro. Eles vão poder agora produzir um filme em película e tudo mais, tudo isso através do trabalho de estar compartilhando conhecimento e ensinando as pessoas habilidades, de estarem usando a tecnologia que hoje em dia faz as coisas serem muito mais acessíveis do que eram antigamente. Hoje em dia, para produzir um vídeo, você consegue fazer isso com um orçamento muito menor do que antigamente. Áudio também, uma rádio... Então tudo isso tem um ponto positivo. E o maior problema é a falta de acesso das pessoas a esse conhecimento e a essa tecnologia. Que a gente também vem tentando quebrar, com essas oficinas, com esses trabalhos.

Você falou de cobertura, de documentário. Você classificaria o CMI também como um projeto de jornalismo, o site do CMI por exemplo, você vê como um veículo jornalístico?

Não é um veículo jornalístico como a Folha de São Paulo ou uma revista que tem comercial, tem propaganda nela, que visa um lucro. É diferente no ponto que a gente trabalha para levar a informação aos lugares que praticamente você não vê na grande mídia. Então é um espaço aberto, de um termo que está sendo muito usado agora, mas que a gente já vem fazendo há uma década, que é o jornalismo cidadão. Da pessoa estar contando a sua própria história. Então é jornalismo sim, no momento em que uma pessoa senta e escreve uma história, conta um fato, ela está relatando um acontecimento não deixa de ser, eu acho que é justamente esse termo que estão usando muito agora, mas que a gente sempre vem fazendo, jornalismo cidadão. Inclusive, só para completar, hoje em dia a própria mídia corporativa vem se pautando na produção de informação por pessoas comuns. Por exemplo, você vê a CNN. A CNN vive falando "saiu isso no Twitter, saiu aquilo no Twitter". A Folha de São Paulo, no caderno de informática, sempre tem ali, mas lógico que eles também fazem uma 
filtragem, vão pegar aquelas publicações ou de pessoas famosas, ou de algumas pessoas que estão no local do acontecimento do momento. Por exemplo, tem pessoas no Haiti agora, eles vão pegar notícias dali. Agora eles estão começando a fazer o que a gente sempre fez. Lógico que eles estão fazendo de forma diferente.

Falando sobre o movimento de antiglobalização, como você acha que a proposta dele se articula com o projeto do CMI, tanto no início, que foi mais ou menos a origem, quanto atualmente? E como você avalia o momento presente desse movimento?

No início o CMI começou através desse movimento, que aconteceu em Seattle. Depois esse movimento foi tendo uma agenda de manifestações e o CMI foi seguindo essa agenda, e desde o começo a gente sempre colocou que a gente tinha que sair dessa agenda, não só o CMI, mas até mesmo os grupos que participavam do movimento antiglobalização, sempre colocavam que a gente tinha que sair dessa agenda de ação global e começar a ter agendas de questões locais, coisas próprias mesmo, e foi isso mais ou menos o que começou a acontecer.

Em um certo ponto, pode-se dizer que mais ou menos em 2004, o CMI começou a se expandir para os movimentos locais, para as pautas locais, para o que estava acontecendo na cidade, o que estava acontecendo na política local, não se esquecendo do que estava acontecendo no resto do mundo, mas se voltando para isso.

O movimento antiglobalização hoje em dia continua o movimento antiglobalização: sempre foi um movimento anticapitalista. No começo ele tinha uma agenda global, hoje em dia já não tem essa agenda global, mas não quer dizer que não tenha movimento. Por exemplo, tinha os dias de ação global, que eram mais ou menos o que todo mundo seguia. Vai ter o encontro do FMI, do Banco Mundial. Ou vai ter o encontro da Cúpula das Américas, ou vai ter o G20, ou então o Fórum Econômico Mundial. Era mais ou menos essa agenda que todo mundo estava seguindo praticamente, e o CMI seguindo também, porque o CMI, de uma certa forma, acompanhava esses movimentos. Então o CMI seguia as ações que aconteciam, e acompanhava essa agenda global. Em um certo período acabou acontecendo isso, o movimento antiglobalização parou de seguir essa agenda global, que teve de certa forma efeitos negativos. Por exemplo, no norte, nos Estados Unidos e na Europa, o movimento enfraqueceu bastante, e isso tem muito a ver com o atentado do 11 de setembro. O 11 de setembro aconteceu semanas antes de uma grande manifestação em 
Washington, contra o Banco Mundial e o FMI. Tinha acontecido, no meio do ano, a manifestação em Gênova, então estava todo movimento já se organizando para fazer uma manifestação maior do que foi em Gênova em Washington. Daí caíram as duas torres e começou toda essa história de terrorismo... em duas semanas a mobilização inteira parou. Eu estava lá, eu tinha reunião, teve uma reunião com trezentas pessoas de diversos grupos que estavam na cidade para estar organizando a manifestação, e depois do 11 de setembro, na reunião, todo mundo foi contra sair na rua com medo mesmo da repressão, do que a polícia podia fazer, porque a polícia de Washington estava noticiando que não dava para distinguir manifestante de terrorista. Então tudo isso causou um gelo geral, principalmente no norte.

Mas se você for ver, na América Latina, o movimento anticapitalista vem crescendo cada vez mais. Lógico que tem aí uma participação que pode ser considerada importante nos governos mais radicais que surgiram nesses últimos anos na América Latina, mas a base disso tudo é o povo. Quando teve o golpe na Venezuela, o golpe só foi quebrado, o pessoal só conseguiu vencer o golpe por causa do povo, não foi o Hugo Chávez sozinho, que fez aquilo, foi o povo da Venezuela que já estava cansado, e que preferiu optar mudança que o Hugo Chávez estava propondo - e que ninguém sabe ainda como vai ser o final disso, mas está optando por isso. A mesma coisa aconteceu na Bolívia e em outros lugares da América Latina, a população está querendo uma mudança e ela nunca parou de lutar contra o capitalismo, que sempre impôs a agenda de Washington nos seus países. Então, na América Latina o movimento hoje em dia está super forte, tem até um texto do Chomsky dizendo que o lugar mais animador no planeta hoje em dia é a América Latina, que aponta uma possibilidade de mudança no cenário político global. Então, na América Latina, pode não ser um movimento antiglobalização, dos coletivos, pequenos coletivos ou grupos de afinidades, da rede de ação global, ou da Ação Global dos Povos. Podem não ser os grupinhos anarquistas, que faziam as ações diretas, as manifestações, como a gente no Brasil, que fez lá as ações diretas contra a ALCA... Mas os movimentos sociais da população em geral continuam ativos e continuam bastante fortes e crescendo sim. Já conseguiram vencer várias ofensivas muito fortes que aconteceram nos últimos anos contra essa demanda de mudança da população. Então a minha visão, no momento, é que o movimento antiglobalização pode ter enfraquecido no norte: na Europa e nos Estados Unidos. Mas em compensação, na América Latina, ele vem se tornando cada vez mais forte e vem 
acontecendo também uma união, de certa forma, entre grupos e movimentos que antes não havia. Por exemplo, tem uma união muito maior entre os países da América Latina, de solidariedade, de um estar apoiando o outro, que antes não tinha, não era tão forte assim. Está se unindo, está se fortificando, ficando cada vez mais forte, e você pode ver que está tendo uma reação super forte da direita contra isso. Não é à toa que teve todas essas tentativas de golpe, teve o golpe em Honduras. Não é à toa que os Estados Unidos fizeram esse acordo com a Colômbia para ter mais bases militares lá. Os Estados Unidos hoje em dia têm treze bases militares circulando, cercando a Venezuela. A intervenção da direita no Brasil, você pode ver a grande mídia nos últimos anos no Brasil como vem atuando. Em qualquer artigo, em qualquer meio que você vê sobre o Cesare Batistti, eles se referem a ele como terrorista, ao Hugo Chávez se referem como um ditador, entendeu? Vêm colocando qualquer iniciativa, por exemplo, em Honduras, não foi o Zelaya, foi a população que tomou a iniciativa, eles fizeram um referendo, eles coletaram 600.000 assinaturas para pedir aquele referendo, um país que tem o quê, um pouco mais de 4 milhões de pessoas, 600.000 assinaturas é um número muito grande. Entregaram isso para o Zelaya e ele só fez o referendo por causa disso. Agora você não vê essa informação na grande mídia.

Então, porque a grande mídia trabalha para direita, está acontecendo uma ofensiva muito grande. Em um momento em que o Jornal da Band fala que o projeto de direitos humanos no Brasil é o primeiro passo para uma ditadura, sabe, você vê que está rolando uma briga forte no continente entre as duas... a direita e a esquerda.

\section{Politicamente você se define como? Você tem alguma tendência?}

Olha, eu me defino como anarquista, mas eu tenho muita crítica para o movimento anarquista de hoje em dia. Praticamente eu não concordo com a atuação e a forma de organização do movimento em quase $90 \%$, mas eu me defino como anarquista e é assim que eu trabalho dentro dos grupos dos quais eu faço parte.

\section{O que você vê de perspectivas em relação ao futuro da Rede Indymedia e do}

\section{Brasil especificamente?}

Eu vejo que, de certa forma, está meio nebuloso. Globalmente falando, porque a estrutura como a rede vem funcionando, vários processos, ficaram viciados, e tem muita gente que continua presente e coordenando esses processos, que estão completamente desconectadas com o resto da rede. Então, no Indymedia, você tem o 
nível do coletivo local, que às vezes o coletivo pode existir por dez anos sem nunca sequer participar da rede global, e tem esse pequeno núcleo, que o pessoal fala "rede global" que é um grupo de pessoas que atuam nessa infra-estrutura da rede global, que seriam as listas, as discussões, e que acabaram criando processos viciosos, que não estão de acordo com a realidade dos coletivos de hoje em dia, e que infelizmente eu acho que precisam de uma mudança radical para poder estar crescendo, evoluindo. E sinceramente, eu não acho isso possível de ser feito no momento. Eu acho que a gente está em um momento super importante da história, que a gente precisa estar concentrando as forças e sendo bastante estratégicos. Foi por isso justamente que eu saí da rede global e resolvi dedicar o meu trabalho para os coletivos latinos, em especial o coletivo Brasil, de que eu faço parte. O CMI Brasil... a gente tem um potencial muito grande. Como eu já falei, a gente é um dos sites mais acessados no Brasil, por exemplo, se você for pegar todos os sites da internet no mundo inteiro, o CMI está na posição cento e poucos mil dos sites mais acessados no mundo inteiro, que não é uma posição ruim. É uma posição boa, e tudo isso é o acúmulo desses dez anos de trabalho. A gente teve um processo muito trabalhoso que a gente acabou de encerrar, que começou no final de 2006 e que atrapalhou um pouco a nossa parte de avanço tecnológico. Falando nessa área, que eu acho que o site também precisa evoluir, ser melhorado. Em 2006 o coletivo técnico do CMI perdeu praticamente todos os voluntários. E também a gente fechou o ano de 2006 sem um servidor próprio, a gente sempre teve o nosso próprio servidor, o nosso site estava hospedado em um outro servidor que não era nosso. Além disso, a rede global perdeu um local de hospedagem de servidor que vinha servindo a gente gratuitamente nos últimos anos, onde estavam mais de dez servidores hospedando dezenas de sites Indymedia, e teve um outra perda de um local onde estavam alguns servidores desse coletivo que eu faço parte, o Line Feed, que também hospeda sites Indymedia, hospeda cerca de dez sites. Foi uma crise muito forte na área técnica. E a gente teve que trabalhar essa parte primeiro. A gente conseguiu um local alternativo de hospedagem para esses servidores, no momento que a gente conseguiu esse local.

O coletivo CMI Brasil começou a trabalhar em reestruturar o coletivo técnico, em convidar pessoas novas, e envolver mais as pessoas que já estavam lá, e que não estavam tão envolvidas, mas vinham acompanhando o coletivo. A gente se organizou e conseguiu ter o nosso próprio servidor. A partir do momento que a gente conseguiu esse servidor, a gente migrou todos os sites que a gente hospeda para ele, aí a gente 
começou a trabalhar em algumas coisas pontuais, do CMI, que ele precisava. E a gente conseguiu terminar isso foi no começo de 2008, quando a gente conseguiu estabilizar a situação técnica, do CMI ter um coletivo técnico atuante, ter um local estável de hospedagem, ter o hardware, toda infra-estrutura necessária para isso. Aí, no final do ano de 2008, tivemos uma reunião no Brasil, no coletivo técnico, e eu apresentei uma proposta de um site novo para a rede. E eu construí essa proposta assim: em 2006 a gente teve uma reunião nacional da rede. Na época a gente estava discutindo a questão de ter sites, páginas dinâmicas para os coletivos locais dentro do site, e tudo mais, tinha uma proposta também de ter uma funcionalidade de promoção de matérias da coluna da direita que seriam promovidas para a coluna do meio... Então eu meio que juntei todas essas propostas e fiz uma proposta de um site novo. Isso foi em agosto de 2008, e aí a gente veio trabalhando nessa proposta, trabalhando com a rede, estudando as possibilidades.

Uma outra coisa também, o software que a gente vem usando, que é o Mirr, e que foi desenvolvido por um voluntário do CMI da Holanda. O desenvolvimento dele foi parado, congelado completamente em 2005, então não está sendo desenvolvido, e a gente tomou a decisão de fazer um site novo usando um software diferente, que a gente já escolheu que vai ser o Drupal, que é um software livre também, e a gente está trabalhando nesse projeto do site novo, que se tudo der certo a gente vai lançar esse ano ainda, com os dez anos do CMI Brasil.

E esse site novo vai estar colocando muita coisa que eu acho que vai melhorar. Inclusive, eu li o seu trabalho, que você mandou em PDF para Foz. Lá você fala na questão de ter pessoas mais velhas acessando o site, não ter pessoas mais jovens, talvez o atrativo da tecnologia nova, então a gente espera que com esse site novo a gente retome o usuário jovem para ele estar acessando o site. A gente tem também funcionalidades novas, por exemplo, o usuário do site vai poder marcar matérias que ele considera que estão em desacordo com a nossa política editorial, a gente fala "flagar", colocar uma bandeirinha [flag] falando que essa matéria deve ser escondida. A gente quer aumentar a participação da comunidade que usa o site do CMI.

\section{Vai descentralizar ainda mais...}

Descentralizar ainda mais. A gente vai ter tanto a opção da pessoa marcar a matéria para ser escondida, quanto a opção da pessoa marcar a matéria para ser promovida. Por exemplo, esses sites como o Digg, em que a pessoa vai lá e vota. 
Número X de votos, o artigo vai automaticamente para uma posição de destaque na coluna do meio, por exemplo. A mesma coisa acontecerá com as matérias que devem ser escondidas. Tudo isso ainda tendo uma supervisão dos voluntários, lógico, porque podem acontecer erros, pode acontecer que uma matéria que deveria ser escondida seja promovida para a coluna do meio, tudo isso ainda tendo uma supervisão, mas descentralizar cada vez mais o processo das coisas no CMI, colocar a comunidade mais envolvida com o funcionamento e a manutenção do site. Outra coisa também que a gente quer colocar é uma ferramenta nova: a gente está instalando um software que funciona igual ao Twitter, que vai ser um software livre que a gente vai estar usando, que vai possibilitar as pessoas criarem grupos, igual ao Twitter, imagina um Twitter em que você pode criar um grupo CMI São Paulo, e ali as pessoas podem ter uma comunicação mais rápida. E além disso, porque a gente vai estar utilizando esse software, vai ser possível a publicação por telefone celular no site. Então já é uma forma de a notícia chegar mais rápido, por exemplo, no caso do Arruda em Brasília, o pessoal ocupou a Câmara, então as pessoas podem mandar atualizações direto do celular que vão estar aparecendo direto no site sobre a ocupação que está ocorrendo ali na Câmara. A gente está em produção, desenvolvendo esse projeto do site novo que já era para ter sido lançado, mas que por causa desses problemas técnicos que a gente teve no final de 2006, até o meio de 2008, foi adiado, e agora a gente está retomando. Estamos com a ideia de lançar este ano ainda, em comemoração aos dez anos do CMI Brasil.

Você falou que agora está se dedicando mais à rede latina e ao Brasil principalmente. Não faz diferença nenhuma pela distância, você acha que não atrapalha nada? Poderia ser mais fácil se você estivesse trabalhando aqui no Brasil? Ou com essa parte tecnológica é mais fácil lidar à distância, também?

É, a parte tecnológica é fácil, até mesmo porque, mesmo se eu estivesse no Brasil, tem gente da Bahia, do Rio, de Goiânia, de Joinville, então o coletivo técnico iria acabar trabalhando virtualmente mesmo, não ia modificar muito. Mas faz diferença no momento que eu não estou... o meu coletivo local sempre foi de São Paulo, então no momento em que eu não estou em São Paulo, não estou com o meu coletivo local. Por exemplo, eu sempre acompanhei os movimento sociais de São Paulo e continuo acompanhando, estou nas listas e tudo mais, mas estando em São Paulo eu fazia um trabalho muito maior, um trabalho de organização. Por exemplo, no 
ano de 2005, o coletivo São Paulo trabalhou junto com o Fórum Centro Vivo e ajudou no lançamento do dossiê de violação dos direitos humanos no centro de São Paulo. Então são trabalhos que, estando localmente, você pode estar fazendo. Abre um leque de oportunidades de projetos e de outras coisas em que você pode estar atuando.

E também ter aqueles pequenos bate papos... nos bate papos que acabam surgindo ideias, ou então desenvolvendo melhor alguma discussão, algum problema que está tendo na rede, e a comunicação virtual é sempre desfavorável nessas situações. Isso aí é um pouco o que me atrapalha no trabalho que eu faço. Mas muita gente do CMI está online o tempo todo, dá para conversar, a gente conversa por Skype sempre, e agora a gente está tentando fazer uma reunião nacional em abril, então eu estou planejando ir para o Brasil para essa reunião para aproveitar a oportunidade, para conversar com todo mundo, porque a conversa cara a cara faz falta sim, com certeza.

Eu terminei minhas perguntas, você tem alguma coisa que você acha que seria legal, que eu não perguntei?

A Foz te passou uns gráficos que eu fiz das publicações no CMI? Eu vou te mandar o link para eles, porque eu estava conversando com a Foz para ver se podia passar para você, que eu achava que seria legal explicar um pouquinho. Dar uma olhada e eu ir narrando algumas coisas que eu vejo, porque eu estou fazendo bastante isso, eu estou colhendo estatísticas do CMI, já faz bastante tempo, tanto em quantidade de artigos que são publicados, como também estatísticas de acesso, do site. Por exemplo, se você for ver, artigos de publicação aberta cresceram bastante nos primeiros anos, mas depois se manteve um nível da mesma quantidade. De mais ou menos 2003 para cá, a gente vem tendo a mesma quantidade de publicação aberta. Se você for olhar a quantidade de editoriais, eu acho engraçado porque editoriais no ano de 2006, foi o ano que a gente teve mais editoriais, e se você for ver o que aconteceu nesse ano de 2006, teve o despejo do Sonho Real em Goiânia, que foi super forte, teve a revolta em Oaxaca, onde um companheiro nosso morreu, o Brad, e teve também muita coisa do Passe Livre que aconteceu no Brasil, manifestação do Passe Livre, e também no centro de São Paulo teve muita manifestação, a população estava mais ativa, mais organizada, se manifestando mais. E você pode ver que aumentou o número de editoriais. 
O lixo aberto tem umas coisas interessantes porque, por exemplo, 2004 e 2005 tem uma quantidade muito grande de lixo aberto, em 2007 também. Parte dessa quantidade do lixo aberto é spam, porque nessa época a gente não tinha ainda o sistema antispam. Tanto que, se você olhar lixo fechado, em 2007, é enorme, no gráfico. A gente em 2007, em discussão, resolveu colocar no lixo fechado porque não fazia sentido colocar no lixo aberto os artigos que eram spam...

\section{Quase um terço...}

É, e o que aconteceu, quando a gente conseguiu terminar a instalação do nosso servidor, que a gente colocou os sites todos para funcionar, a gente começou a fazer pequenos ajustes nos sites, e foi aí que a gente implementou o sistema contra spam, a partir daí, 2008, 2009, você pode ver que caiu de novo, o conteúdo.

No final tem o valor total, das publicações. Você vê que o coração do CMI é a publicação aberta. Outra coisa que eu também venho percebendo é que a publicação aberta do CMI veio mudando durantes anos. No começo ela ainda era muito focada nos movimentos de ação direta, os anarquistas, os grupos autônomos. Depois, com o tempo, ela foi se expandindo, pessoas que não eram envolvidas com esses movimentos começaram a utilizar o CMI, e hoje em dias a gente tem assuntos mais diversificados na coluna da direita, tem mais informações de movimentos indígenas, que foi uma coisa que aumentou durante o tempo. No começo do CMI Brasil a gente quase não tinha cobertura sobre o movimento indígena.

Um outro fenômeno que está acontecendo no Brasil, com a expansão da internet, e a facilidade de as pessoas estarem criando blogs e tudo, é que está tendo uma posição mais crítica da população ao que a mídia corporativa publica, o famoso PIG, partido da imprensa golpista. Então está tendo uma ação no Brasil de as pessoas estarem indo contra o que é publicado e desmentindo quando uma matéria é manipulada, essas coisas. E esse tipo de publicação também vem aumentando no CMI.

Outra coisa que eu acho interessante é que, apesar da facilidade de as pessoas estarem tendo o seu próprio blog, elas publicam no seu próprio blog e também publicam no CMI. Por que isso? Porque o CMI tem mais acesso do que o blog delas. Então o CMI continua sendo uma ferramenta de difusão da informação do que não tem muito acesso. Apesar de a pessoa ter um movimento, ou a pessoa ter um blog ou site próprio, ela ainda tem essa dificuldade: está na internet, mas quem está vendo? 
Um número muito pequeno de pessoas. Ela sabe que, no momento em que ela colocar no CMI, a tendência é triplicar essa quantidade de acesso da informação que ela está publicando. Então o CMI continua servindo como isso.

Mudou um pouquinho o papel, mas a importância ainda continua, é isso que você esta falando?

Exatamente. E a gente tem uma ideia de fazer no site novo uma seção com sites que seguem a mesma política do CMI, de movimentos sociais. Vai pegar automaticamente as notícias desses sites, justamente para a gente fazer com que o número de acesso que chega no CMI vá para esses sites também. Para aumentar o número de acessos desses sites. E dessa forma eles ocuparem uma posição melhor no ranking no Brasil e ficarem mais conhecidos, é uma ajuda que a gente pode dar, porque a gente tem uma posição melhor do que eles devido ao tempo há que a gente existe e tudo mais.

Outra coisa também que é interessante é que, quando o CMI começou, a gente defendia o Copyleft, mas naquela época pouquíssimas pessoas sabiam, entendiam essa questão. E hoje em dia é algo muito mais conhecido, e você pode ver que isso já está virando prática. Por exemplo, tem gente que critica que o CMI publica um artigo que não foi produzido pelo CMI, foi produzido por um outro grupo, ou outro coletivo. Eu já vejo isso diferente, eu acho que no momento que a gente sempre defendeu que o nosso conteúdo é livre, a gente tem que apoiar aqueles grupos que também estão produzindo conteúdo livre. Você estar republicando um conteúdo que é Copyleft é fortalecer o Copyleft. Porque você tem que colocar só a marca e dizer "eu produzi esse conteúdo para publicar no site"? Eu acho que no momento em que você publica um artigo do Passa Palavra ou da Carta Maior - ambos lançam todos os seus artigos sobre a licença Copyleft -, você está fortalecendo a ideia de compartilhar o conteúdo. O Passa Palavra é um site excelente, mas se você comparar a quantidade de acesso que ele tem com o do CMI, o CMI tem muito mais acesso. No momento em que a gente republica um artigo que foi feito pelo Passa Palavra no nosso site, a gente vai estar aumentando o número de pessoas que estão lendo esse artigo. E na web hoje em dia, isso é o que forma a internet. Não é uma coisa de "ah, você está duplicando o mesmo conteúdo por aí". Os leitores são diferentes, pode ter uma pequena porcentagem de leitor que lê a Carta Maior, e o CMI e o Passa Palavra. Mas é muito pequeno, se você for comparar com o número total de leitores. Por exemplo, só para 
você ter noção, em dezembro do ano passado, a média que o CMI teve foi de 52 mil acessos, textos lidos no site. Essa é a média, só no mês de dezembro, é uma quantidade muito grande de pessoas que estão indo no site. É uma forma de apoiar o movimento mesmo. Se a gente está produzindo, tudo bem, a gente coloca o que a gente fez, mas em um momento que não teve tempo ou não teve gente para escrever, para acompanhar uma história, e um outro movimento publicou sobre aquilo, ou um outro grupo publicou sobre aquilo, não vejo como negativo você pegar aquele conteúdo e publicar no site, pelo contrário, fortalece mais o movimento e fortalece mais a ideia do Copyleft também, de compartilhar o conteúdo. Que vai contra o que a mídia corporativa faz: a mídia corporativa quer colocar ali embaixo Folha Online, Globo, Estadão, eles querem vender a marca deles. A gente não, a gente quer informar as pessoas, então não importa quem escreveu.

Eu estou vendo e observando essas coisas, tanto na conjuntura no Brasil, da população em relação à mídia, quanto como que a população vem agindo, sendo mais ativa e menos passiva. Ela se informa, ela também critica e ela também informa outras pessoas, dizendo: "olha essa informação foi manipulada, isso não é verdade, olha aqui o fato".

Então tudo isso, essa conjuntura também do que aconteceu no ano passado, a Conferência Nacional de Comunicação, você vê que os meios corporativos estão com medo, estão agindo na ofensiva. No momento em que eles não participaram da Conferência... A Conferência pode não dar em nada, mas pelo menos ela colocou o debate, nacionalmente. Além disso, o fato da mídia corporativa não ter participado, cria uma crítica, um senso crítico maior em relação a eles, porque que eles não estão lá. Outra coisa, a reação da mídia, que está sendo ridícula, sobre o problema dos direitos humanos, e a Folha ter falado que a ditadura no Brasil foi uma "ditabranda". Você vê as reações das pessoas, está tendo uma campanha enorme contra a Folha, em relação à posição dela nos últimos anos, de não assinar mais a Folha e tudo mais. A gente tem que aproveitar essa conjuntura e ajudar toda essa fabricação de conteúdo que está surgindo de forma independente a estar tomando força, a chegar no ponto que ele também seja um formador de opinião pública, para bater de frente com os meios corporativos. Então no momento em que você está compartilhando um conteúdo, é um trabalho em rede, é um conjunto que você está fazendo, é uma forma diferente de atuar, que é a proposta do CMI. O CMI nunca quis atuar dentro dos eixos normais de uma mídia. Desde o momento em que a gente lançou o site com comunicação aberta, 
a gente sempre veio questionando e oferecendo formas alternativas de fazer esse trabalho, que não segue a forma tradicional. Essa é a nossa esperança, de estar melhorando isso com o site novo, de estar melhorando a dinâmica no site, aumentar a participação da comunidade do site, e também de ter essa página que pega notícias dos outros sites, dos sites do MST, do Movimento Passe Livre, do Movimento Sem Teto, do Santuário dos Pajés, que seja, e que as notícias deles apareçam no CMI automaticamente, para poder carregar o nosso tráfico de usuários para eles também e aumentar a ofensiva contra a grande mídia. 


\section{Capítulo 4}

\section{Caracterizando os voluntários do CMI - discurso e práticas}

\subsection{O discurso do grupo que constitui o CMI - frame analysis}

Como se pode perceber, o CMI é um projeto cujas batalhas no campo discursivo são centrais e diretas, já que seu objetivo principal é fornecer uma cobertura informativa alternativa à da mídia comercial, e a organização em si estrutura-se ao redor de um veículo de comunicação (site) elaborado coletivamente. Para descrever mais profundamente o projeto e, simultaneamente, os seus participantes, é necessário então voltar os olhos para as narrativas que os mesmos constroem, seus discursos e retóricas.

Assim, julgamos que a perspectiva da análise frames, detalhada adiante, e já largamente usada para estudos de mídia (especificamente, aqueles que investigam os frames interpretativos construídos pela mídia) adequada ao propósito. É uma ferramenta útil para abordar aspectos das questões culturais e discursivas de grupos sociais, pois apresenta uma medida de clareza coerente com o que requerem as investigações que mesclam o empírico e o teórico, como é o caso.

Não se quer negar em nenhum momento a opacidade dos discursos dos movimentos sociais ou projetos que lidam com os mesmos, como o CMI, e nem a utilidade de abordagens que tentam descer em níveis mais profundos nos meandros da significação, nesta ou em outras disciplinas. A proposta da frame analysis, porém, é apreender os aspectos mais facilmente equacionáveis desta dimensão "fugidia", revelando principalmente as disputas estratégicas que se dão em seu terreno.

Neste caso, ao invés de verificar como a mídia realiza enquadramentos interpretativos em relação aos fatos, vamos ver como um veículo de mídia alternativo realiza com mais ou menos sucesso seus processos de frame alignment. Para esta análise, após uma exposição dos conceitos teóricos, serão a eles relacionados trechos das entrevistas abertas com os voluntários constantes no Capítulo 3, bem como alguns conteúdos postados no site, a comunicação entre os participantes-moderadores do CMI via lista de discussão por email, e falas registradas em reuniões presenciais das quais participamos. 


\subsubsection{Frames: da estratégia à cultura, da cultura à estratégia}

Paradigmas dominantes na sociologia dos movimentos sociais norteamericana, as primeiras versões da teoria da mobilização de recursos (MR), bem como da teoria do processo político (TPP) sofreram sucessivas críticas em relação à ausência da relação entre a ação coletiva e a dimensão cultural (McClurg, 1992), e particularmente da relação dos atores individuais e coletivos com a mesma, que é do que tratam conceitos como ideologia e identidade coletiva.

Reforçou estas críticas a cultural turn vivida pelas ciências sociais desde a década de 1970, quando um número crescente de cientistas passou a voltar sua atenção a como os homens entendiam o mundo, e não somente aos seus comportamentos supostamente objetivos (Jasper, 2007).

Num empreendimento de reelaboração da teoria, e de trazer à luz temas até então tratados como irrelevantes para as discussões, alguns acadêmicos se esforçaram por incorporar a questão da construção de significado no paradigma da MR, passando a focalizar a formação do ator em relação a ideias, valores, e interpretações e o contexto social em que os significados são elaborados e transformados; num sentido amplo, o conteúdo cultural dos movimentos sociais.

Nesta nova perspectiva, entende-se que o ator não só está vinculado socialmente em termos de identidade de grupo e situado culturalmente, sendo influenciado por valores e significados ${ }^{36}$, como também ele mesmo atua na construção destes valores e significados, de maneira interativa.

Uma das primeiras ferramentas conceituais acessada pelos autores que utilizam estas abordagens toca particularmente na questão da construção interativa do significado. São os frames e os collective action frames, definidos por David Snow, Robert Benford e colaboradores (1986). A esfera política é assim aproximada da

\footnotetext{
${ }^{36}$ Um dos primeiros pontos problemáticos na teoria da mobilização de recursos, como apontou Jason DeFay:

"While RM theorists tend to treat grievances as being relatively constant background factors that do not bear significantly on the rise of specific social movement organizations, critics of this perspective suggest that grievances themselves can often be imbedded in the very social fabric which gives rise to new protest movements and express ongoing social tensions."

"Enquanto os teóricos da MR tendem a tratar as queixas como sendo fatores contextuais relativamente constantes, que não incidem significativamente sobre o aumento de determinadas organizações de movimento social, os críticos desta perspectiva sugerem que as queixas muitas vezes podem estar embutidas no próprio tecido social que dá origem a novos movimentos de protesto e expressam as tensões sociais em curso." (DeFay, sem data, tradução nossa)
} 
sociologia da cultura e da psicologia social, já que os collective action frames envolvem disputas estratégicas, ideologia e outros materiais culturais, além de cognição.

A cultura em questão aqui não é a considerada como variável latente, que apareceria manifesta nos produtos culturais da mídia e nos valores embutidos nas práticas diárias. Tal visão da cultura unitária e coerente internamente a um dado grupo continuaria explicando o desinteresse em sua dimensão pelos estudiosos da mobilização de recursos e da teoria do processo político, já que ela assume que os indivíduos incorporam a cultura e seus valores por socialização, sem maiores problemas.

O conceito que subjaz tal enfoque é o de cultura como fonte de elementos que podem ser submetidos a um uso estratégico (DiMaggio, 1997). Significados, crenças, ideias, práticas, valores, mitos e narrativas: tudo isso é parte do "toolkit" 37 e pode ser mobilizado para os fins das organizações, modelando - intencionalmente ou não novos elementos culturais e novas molduras interpretativas (Snow e Benford, 2000b).

Daí a definição de movimentos sociais tanto como consumidores de significados culturais existentes quanto com produtores de novos significados (Tarrow, 1992 apud Snow, 2000). Não é tanto o que a cultura faz, mas o que as pessoas fazem com ela. Se as pessoas utilizam a cultura estrategicamente, então as culturas em que as pessoas são socializadas deixam bastante espaço para variedade. E a cultura naturalmente não será um todo homogêneo e coerente a ser absorvido, mas fragmentada, mesmo entre um grupo situado em um mesmo contexto: "all real cultures contain diverse, often conflicting symbols, rituals, stories and guides to action" / "todas as culturas reais contêm símbolos, rituais, histórias e guias para a ação diversos, e muitas vezes conflitantes.” (Swidler, 1986, tradução nossa)

\footnotetext{
${ }^{37}$ Anne Swidler (1986) partiu dos conceitos de Pierre Bourdieu [como os habitus - esquemas de pensamento, avaliação e julgamento que seguem uma lógica prática (Bourdieu, 1977)] para construir uma definição que enfatiza a dimensão prática da cultura. Esta seria um "kit de ferramentas" de símbolos, histórias, rituais e visões de mundo que as pessoas poderiam usar em variadas configurações para resolver diferentes tipos de problema. A cultura então teria efeitos causais não porque os agentes se movem orientados por valores como fim, mas porque fornece componentes culturais - repertório de hábitos, competências e estilos, muito mais do que preferências e desejos - que são usados para construir estratégias de ação, maneiras persistentes de ordenar a ação ao longo do tempo. Em relação a esta definição, em microcontextos os collective frames teriam um papel semelhante ao que ela atribui às ideologias: "establish new styles or strategies of action" / "estabelecer novos estilos ou estratégias de ação”. (Swidler, 1986, tradução nossa)
} 
Com efeito, argumenta-se que os paradigmas da TPP e da RM puderam incorporar o conceito de frames com uma certa facilidade ${ }^{38}$ porque os mesmos eram vistos como espécie de "recursos" que os recrutadores dos movimentos teriam que usar corretamente para obter sucesso (Jasper, 2007). Mas seus proponentes também perceberam que estes recursos, envolvendo uma natureza diversa da material e dos arranjos políticos institucionais, ensejam análises mais complexas sobre suas disputas. Não são meros pacotes estáticos a serem apropriados: têm que ser construídos, ou no mínimo apropriados, trabalhados e retrabalhados continuamente.

Duas dimensões ganham importância: a ação (agency), respondendo ao rótulo de "estruturalistas" dado a estas teorias, e o caráter processual. Ao contrário do ator calculista racional (economistic rational) (McClurg, 1992) de antes, temos atores que tanto constroem ativamente quanto são influenciados por um mundo de significações sociais, enraizados em contextos históricos específicos, e baseados em experiências e identidades étnicas, de gênero, classe e nacionalidade. É dentro de tais contextos que identificam e constroem significados que orientam a mobilização.

Os próprios organizadores dos movimentos passam a ser vistos como agentes ativamente engajados na produção e manutenção de significação para os participantes, antagonistas, espectadores e observadores; profundamente envolvidos em disputas junto a mídias, governos locais e Estado, em uma verdadeira "política de significação"

\footnotetext{
${ }^{38}$ Como exemplo, temos os autores do volume Comparative Perspectives on Social Movements que adotam o conceito de framing, juntamente com os de oportunidades políticas e estruturas de mobilização:
}

"Most political movements and revolutions are set in motion by social changes that render the established political order more vulnerable or receptive to challenge. But these "political opportunities" are but a necessary prerequisite to action. In the absence of sufficient organization - whether formal or informal - such opportunities are not likely to be seized. Finally, mediating between the structural requirements of opportunity and organization are the emergent meanings and definitions - or frames shared by the adherents of the burgeoning movement."

\footnotetext{
"A maioria dos movimentos políticos e revoluções são colocados em movimento por mudanças sociais que tornam a ordem política estabelecida mais vulnerável ou receptiva ao desafio. Mas essas 'oportunidades políticas' não são um pré-requisito para a ação. Na ausência de organização suficiente -

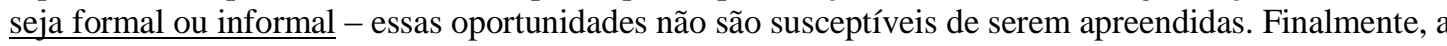
mediação entre as exigências estruturais de oportunidades e de organização são os significados e definições emergentes - ou frames - partilhados pelos adeptos do movimento que cresce." (McAdam, McCarthy, e Zald, 1996, tradução e grifos nossos).

Todavia, é importante ressaltar que a chave dos frames não foi a única utilizada pela TPP para acessar a dimensão cultural, não sendo os mesmos igualados à cultura nos movimentos sociais. Além dos "repertórios", que numa etapa posterior se aproximam do interacionismo simbólico ao serem redefinidos como conjunto de rotinas a serem "interpretadas", o conceito de identidade também apareceu na obra dos autores da teoria.
} 
(Snow e Benford, 1988). São assim responsáveis diretos pelas mudanças culturais, quando enquadramentos novos ou reelaborados são assimilados pela cultura política, mesmo que nem sempre da maneira como intencionavam. Isto em razão do seu caráter de discurso, e não de um recurso material ou político qualquer: também há interpretação ativa do lado de fora do movimento, com indivíduos e grupos fazendo releituras das leituras que os collective action frames trazem para eles.

\subsubsection{Collective Action Frames}

O termo "frames" faz referência ao conceito de Erving Goffman que define os esquemas interpretativos que os indivíduos adotam para dar sentido ao mundo e se situarem nele. Seriam estruturas cognitivas básicas que guiam a percepção e a representação da realidade (Goffman, 1974).

Goffman falava do papel dos frames na organização da experiência de um ator individual, mas seu conceito foi remodelado por Benford, Snow e colaboradores nos "collective action frames": "action oriented sets of beliefs and meanings that inspire and legitimate social movement activities and campaigns" / "conjuntos de crenças e significados orientados para a ação que inspiram e legitimam as atividades e campanhas dos movimentos sociais”. (Snow e Benford, 1992, tradução nossa).

Para atrair novos participantes, os movimentos sociais devem construir collective action frames que encontrem receptividade nos indivíduos que estão tentando mobilizar, que os "convençam" - trabalhando em cima de percepções, valores e assunções que os mesmos já possuem e fazem em relação à realidade - da validade do engajamento na ação por determinada causa.

Como os frames, os collective action frames desempenham um papel interpretativo (simplificar e condensar aspectos do mundo exterior), mas incluem também um aspecto coletivo e orientado para a ação. Quanto ao "coletivo", ressalte-se o caráter processual a que nos referíamos: não são meras agregações de percepções individuais, mas o resultado da negociação de significados partilhados (Gamson, 1992). Os frames individuais devem ser articulados coerentemente em frames da organização (Croteau e Hicks, 2003).

O fato de serem "orientados para a ação" também lhes fornece sua particularidade. Gamson (1992) coloca a idéia de agency dos participantes (sentimento da eficácia do agir coletivo e oposição ao de imutabilidade da situação) 
como um dos componentes centrais do collective action frame, ao lado da identidade (definição de um "nós" em oposição a um "eles" concreto) e do sentimento de injustiça (indignação moral expressa na forma de consciência política, uma "cognição quente", que é aquela que une o julgamento intelectual a uma emoção).

Também se enfatizam os agentes pela premissa de que realidade social é construída ativamente pelo entrecruzamento dos mesmos: nas práticas discursivas eles atribuem, interpretam, criam e reconstroem os fenômenos pela sua nomeação.

Os collective action frames são então um conceito intermediário mais específico que mentalidade social (muito ampla, de longa duração, sem foco e nãoorientada para a ação - já que se constitui de crenças populares passivas sobre uma dada sociedade) e que cultura política, apesar de ambas servirem de base para a construção dos frames. Empiricamente acessíveis, ajudam a entender como as pessoas constroem definições das situações de maneiras que levam à ação coletiva. $O$ conteúdo das mensagens dos movimentos é relacional, e por isso a análise de frames pode mostrar justamente como os símbolos ideológicos dos movimentos sociais interagem com mentalidades sociais mais amplas e culturas políticas (Tarrow, 1992).

\section{Por que frames e não ideologia?}

Apesar dos numerosos estudos acadêmicos na área de movimentos sociais e também de mídia que recorreram à perspectiva do framing (Snow e Benford, 2000), já se questionou (Oliver e Johnston, 2000) a validade do construto para se trabalhar com os pontos de vista políticos, quando o já existente e utilizado conceito de ideologia poderia muito bem dar conta do propósito. Mas conforme os próprios criadores argumentam, o conceito de framing traz dinamismo para as definições estáticas de ideologia, demonstrando como os seus componentes (redefinidos como "tarefas centrais de framing - ver na continuação desta dissertação) são socialmente construídos por meio de uma série de "articulative, punctuating and attributional processes"/ "processos articuladores, pontuadores e imputadores" (Snow e Benford, 2000b, tradução nossa). As ideologias têm tido um uso descritivo, com explicações que não descem ao nível de como as mesmas surgem e são apropriadas pelos movimentos. Já os collective action frames, muito além de entidades cognitivas individuais, são fenômenos dialógicos, e devem ser entendidos como produtos interacionais e mutáveis - e que por isso podem auxiliar na compreensão dos processos de mudança cultural. 
Mesmo assim, Snow e Benford não conclamam ao abando do conceito de ideologia, e sim o re-situam como recursos culturais que também são utilizados na construção dos collective action frames:

$[\mathrm{I}] \mathrm{t}$ is arguable and empirically demonstratable that collective action frames are typically comprised, at least in part, of strands of one or more ideologies. If so, then collective action frames are rooted, in varying degrees, in extant ideologies, but are neither determined by nor isomorphic with them. Instead, from a framing perspective, ideologies constitute cultural resources that can be tapped and exploited for the purpose of constructing collective action frames, and thus function simultaneously to facilitate and constrain framing processes (Benford and Snow 2000; Snow and Benford 1988). Following Swidler (1986), we are arguing that if culture is best conceived as a "bag of tools," then clearly ideologies function in this fashion in relation to collective action frames. As well, extant ideologies, or aspects of them, can function as points of contention to which collective action frames are developed and proffered as antidotes or emergent counter-ideologies.

É discutível e empiricamente demonstrável que os frames de ação coletiva são tipicamente compostos, pelo menos em parte, por traços de uma ou mais ideologias. Se assim for, então frames de ação coletiva estão enraizados em diferentes graus, nas ideologias existentes, mas não são determinados por e nem isomórficos com as mesmas. Em vez disso, numa perspectiva de frames, as ideologias constituem recursos culturais que podem ser utilizados e explorados para a construção das estruturas de ação coletiva e, assim, ter a função simultânea de facilitar e delimitar os processos de framing (Benford e Snow 2000; Benford e Snow, 1988). Seguindo Swidler (1986), argumentamos que se a cultura é concebida como uma "maleta de ferramentas", então claramente as ideologias funcionam dessa forma em relação aos frames de ação coletiva. Do mesmo modo, as ideologias existentes, ou aspectos delas, podem funcionar como pontos de discórdia em que frames de ação coletiva são desenvolvidos e propostos como antídotos ou contra-ideologias emergentes. (Snow e Benford, 2000b, tradução nossa) 


\subsubsection{Frame alignment}

O frames propostos por um grupo ou movimento social precisam fazer sentido - não só racional, mas cultural e contextualmente - para os indivíduos e grupos com quem se pretende compartilhá-los. Nos processos de frame alignment ${ }^{39}$ é feita a ligação entre as orientações interpretativas dos indivíduos e de um grupo, e é deles que depende o nível de aderência à organização.

Há quatro processos identificados referentes ao frame alignment: 1. ligação (frame bridging), 2. amplificação, 3. extensão, e 4. transformação do frame.

- Ligação (frame bridging): conexão de dois ou mais frames a respeito de um mesmo assunto, ideologicamente congruentes, mas estruturalmente desconectados.

Uma conexão que detectamos nos discursos dos voluntários do CMI é entre a democratização da tecnologia e a da comunicação. Em particular recentemente, com a difusão da internet e meios digitais, traça-se uma identificação entre o acesso aos meios tecnológicos (que mesmo celebrado, ainda é parco, como mostram os números) e o poder de comunicar.

Vejamos como essas e outras conexões aparecem em algumas entrevistas:

“A tecnologia na mão de povos em situação de genocídio físico e cultural pode ser usada como socorro, e para fazer denúncias de violações graves de direitos humanos."

“A partir da Lei de Terras (1850), legaliza-se o latifúndio da terra. E assim começa o "latifúndio da grande mídia", que passa a pertencer aos mesmos donos dos latifúndios da terra, criando uma retroalimentação de poderes econômicos, sociais e midiáticos. Então, a questão fundiária se desdobra, até porque muitos dos donos das redes de mídia são também latifundiários e políticos, e isso se perpetua desde 1850 até os dias atuais, este é o cenário político que explica, por exemplo, a atuação do

\footnotetext{
${ }^{39} \mathrm{Na}$ definição original dos autores, "the range of interactive processes devised and employed by SMOs and their representative actors to mobilize or influence various target groups with respect to the pursuit of collective or common interests."

"a gama de processos interativos elaborados e utilizados por organizações de movimentos sociais e seus atores representativos para mobilizar ou influenciar vários grupos-alvo no que diz respeito à busca de interesses coletivos ou comuns”. (Snow e Benford, 1988, tradução nossa)
} 
Congresso Nacional e o estranho comportamento do Ministério das Comunicações. (Trechos de entrevista com a voluntária Miryám Hess. Íntegra no Capítulo 3)

“(...) quem detém as licenças para o meio de comunicação, detém parte dos meios - se for pensar em televisão, rádio - e é outra escala, é outra coisa. Por outro lado, e acho que o CMI também tem a ver com isso, as coisas mudaram muito com a internet e as mídias instantâneas. Isso deu acesso muito maior às pessoas, muito mais pulverizado, porque há uma diversidade de iniciativas, não é como estar metade do Brasil assistindo ao Jornal Nacional. Eu acho que isso colabora em algum sentido. Mas nem por isso também a internet deixa de ter seu lado comercial." (Trecho de entrevista com a voluntária Isadora. Íntegra no Capítulo 3)

“Com tanta tecnologia, se as pessoas fossem formadas para serem críticas que não é o que acontece..." (Trecho de entrevista com o voluntário Marcelo. Íntegra no Capítulo 3)

“(...) não é o todo movimento social que tem dinheiro para comprar uma câmera e nem tem interesse em comprar uma câmera para ficar divulgando na internet. Mas eu acho sim que a internet se tornou uma forma de você poder se expressar."

“Ainda tem algumas coisas que não estão sendo usadas com praticidade pelos movimentos sociais. E acho que a tecnologia que eles têm nas mãos hoje daria para fazer muita coisa que ainda não é feita.”

“(...) A pessoa tira uma foto e vai por aonde? Não tem um jornal próprio, não tem acesso à internet. Tem um acesso à tecnologia, mas não é total. Quando tem foto, não tem internet, quando tem internet, não sabe escrever, quando sabe escrever, não sabe gravar um áudio, quando sabe gravar, não sabe onde disponibilizar..."

"E isso que você falou, de quando o acesso for bem democrático... Não vai ser bem democrático, sabe? É só pegar o que o governo está fazendo agora de acesso à internet pelas empresas, é ridículo. Não é para ter acesso para todos. O próprio governo podia dar acesso, mas o lobby por trás é muito maior. Se for aprovada a Lei Azeredo, nem será possível as poucas cidades que fazem isso hoje darem acesso gratuito. Logo se vê que não há uma vontade de democratização. Por que é que rádio de pequena potência não pode? Não faz sentido nenhum, e não pode. Então, não existe 
uma vontade política de democratizar a comunicação." (Trechos de entrevista com a voluntária Foz. Íntegra no Capítulo 3)

- Amplificação: clarificação e fortalecimento de um frame interpretativo sobre um determinado tema, evitando assim ambiguidade ou indiferença em relação ao mesmo.

A necessidade de independência, principalmente econômica e política, é continuamente reforçada, mesmo que já esteja no nome do projeto.

"Eu desconheço qualquer grande veículo aqui no Brasil que seja autônomo e independente. O mais próximo disso é o CMI.”

"Não acho que o CMI tenha que trabalhar com ONG. E mesmo jornalismo, em ONG, acho que está errado. Falta requestionar o que é jornalismo no Brasil, e jornalismo no Brasil é comércio. (...) E ONG é comércio.” (Trechos de entrevista com a voluntária Foz. Íntegra no Capítulo 3)

- Extensão: aumentar a abrangência ou escopo dos frames interpretativos para que façam sentido para pessoas que não viam nenhuma ligação pessoal com as "causas" do movimento.

“Houve um histórico, que vai do final do século XIX até os anos 70, onde o movimento social estava atuando sob o guarda-chuva do movimento operário. Nos anos 70 ele se fragmenta com a luta das mulheres, dos negros, dos jovens, e a luta ecológica. O movimento de antiglobalização faria a convergência dessas lutas. $\mathrm{O}$ processo de liberalização econômica estava fazendo com que essas lutas convergissem do ponto de vista prático, porque ele afetava simultaneamente todas elas. Parecia, de longe, uma coisa sem pé nem cabeça, um movimento que não sabia o que era. Mas isso era para quem estava olhando de fora, porque para gente era exatamente isso: o processo de liberalização econômica estava afetando todos esses movimentos e permitia que a gente construísse uma plataforma comum. (...) O CMI também permitiu que diversos grupos que estavam atuando se encontrassem na parte de comunicação."

“(...) Já tinha essa ideia de unir os movimentos na própria organização estética do site. Era o nosso discurso, mas - acho eu - que ele era usado de fato pelo movimento antiglobalização. Que de certa maneira era a convergência, e de certa 
maneira não era, porque tinha um grupo de pessoas ali que só se dedicavam ao movimento antiglobalização.(...) [Isso] foi mudando, porque quando esse movimento antiglobalização desapareceu, as pessoas se voltaram para os outros locais, e aí o CMI assumiu o papel de tentar fazer, do ponto de vista da comunicação, e não do ponto de vista prático - como era a nossa plataforma no ano 2000 - essa convergência." (Trechos de entrevista com o voluntário Pablo Ortellado. Íntegra no Capítulo 3)

“O coletivo aqui de São Paulo, por exemplo, é formado por uma equipe muito pequena, e que trabalha mais a questão de moradia. Quando eu cheguei, ninguém tinha muita familiaridade com a questão indígena. Tinha apenas uma pessoa que dava notícias nesta área, e eu comecei a dar outras mais amplas e o pessoal achou legal.” (Trecho de entrevista com a voluntária Miryám Hess. Íntegra no Capítulo 3)

"Eu acho que, de alguma maneira, estão todos ligados sim [os movimentos sociais envolvidos], porque eles estão querendo quebrar com essa estrutura atual, desde o MST querendo quebrar o latifúndio, até o Software Livre querendo quebrar a estrutura da Microsoft, que era hegemônica na internet, nos computadores. Então acho que sim, eles estão ligados nessa tentativa de mudança. (...) O próprio CMI, por exemplo. A gente apóia o MST, mas tem discordâncias fortes com ele, políticas mesmo. Mas se o ocorre uma desocupação importante dentro do MST, é lógico que a gente vai apoiar o MST. Mas não é um apoio cego, a gente questiona. Só que, em um momento importante ali, sabe, é a mesma coisa do consenso. Às vezes você tem que, para não ficar travado, abdicar um pouco das suas discordâncias" (Trechos de entrevista com o voluntário Flecha. Íntegra no Capítulo 3)

"O CMI sempre buscou proximidade com os movimentos sociais diversos, de todo o tipo, inclusive tentando levar esta idéia dos movimentos fazerem suas próprias mídias. Então, por exemplo, hoje há o site do Fórum Centro Vivo, que foi uma pessoa do CMI que ajudou a fazer. O CMI adquiriu um know-how técnico e começou a ajudar outros movimentos a terem seus sites, etc. Mas queríamos muito que tivesse uma pessoa de cada movimento dentro do CMI, para falarmos sobre a técnica jornalística, de redação, e levar essa consciência sobre mídia, sobre imprensa, para dentro dos movimentos." (Trecho de entrevista com o voluntário Marcelo. Íntegra no Capítulo 3) 
"Na verdade, houve uma época em que o pessoal ia e fazia mobilização junto, mas não tinha uma articulação muito grande entre estes movimentos. Hoje, tem gente do CMI que participa do Fórum Centro Vivo, do movimento por moradia, do movimento GLBT, da Biroska, assim, 'ene'. Então o pessoal que está no CMI é muito atuante em outros movimentos. O CMI conseguiu se capilarizar dentro dos movimentos sociais. Até pode ter movimento que não tem gente que faz parte do CMI, mas aquele movimento conhece o CMI, já o utilizou ou utiliza"

“(...) o CMI teve um ganho muito grande nestes últimos, anos e quem não enxerga é porque não quer ver. A ponto de a gente fazer nosso encontro de 2007 numa base do MST lá em Brasília. Fomos numa ocupação e fizemos nossa reunião nacional lá dentro, coisa que seria inimaginável antes. (...) O que eu vejo então é um grande ganho. Sinceramente, a crítica para o CMI antes era de que seria um bando de burguesinhos da USP e da PUC que estavam ali fazendo isso, pessoal só de universidade, e que daí era muito fácil, etc. Hoje não, essa crítica corremos atrás [de superar]".

"[É necessário] Integrar-se com os outros movimentos, com o que está acontecendo na realidade, apresentar mesmo o CMI para essas pessoas, tentar fazer elas usarem. Alguns movimentos se apropriaram, outros não. Outros a gente tenta até hoje conversar, explicar como é que publica. E para o novo site a gente já está pensando nisso também." (Trechos de entrevista com a voluntária Foz. Íntegra no Capítulo 3)

- Transformação: processo de "reframing", isto é, reelaboração de um frame interpretativo que não se mostra mais adequado ao contexto ou às insatisfações que o movimento deseja sanar.

"Quando o Indymedia nasceu em Seattle, muito vinculado ao movimento antiglobalização - em particular contra a OMC, em 1999 -, o objetivo inicial era bem diferente do que é atualmente. Se você pegar os primeiros documentos, a ideia era um pouco a da Ciranda da Informação, aquele grupo ligado ao Fórum Social Mundial. Era fazer um site de trabalho cooperativo, no qual diferentes veículos independentes colaborariam, sem direitos autorais, por ele ser livre, de maneira que substituísse uma cobertura concorrente por uma cobertura cooperativa. (...) Durante os protestos de 1999, as pessoas se apropriaram dos veículos de comunicação, e ele mudou 
completamente a cara. Então ele deixou de ser um projeto de jornalistas que estariam cooperando, e passou a ser um projeto no qual as pessoas seriam os verdadeiros atores. Esse foi um entendimento com que o próprio público da internet estava sinalizando."

"[Isso] foi mudando, porque quando esse movimento antiglobalização desapareceu, as pessoas se voltaram para os outros locais, e aí o CMI assumiu o papel de tentar fazer, do ponto de vista da comunicação, e não do ponto de vista prático como era a nossa plataforma no ano 2000 - essa convergência."

"Eu acho que ele [ $O$ CMI Brasil] é mais anarquista/autonomista. (...) Eu achava que se entrássemos só nesse campo autonomista ele ia se 'guetizar', como de fato, durante muitos anos, ele se 'guetizou'. O CMI foi realmente ganhar importância no Brasil depois de uns dois ou três anos já de existência. Ele era muito pequeno. Era um publicando para o outro, a gente tinha 300 acessos diários, era pequeno. Ele ganhou essa dimensão nacional bem depois."

"[ $O$ site do $C M I]$ não tem a mesma centralidade que tinha no momento original. Porque os movimentos arrumaram outros meios de auto-expressão. (...) $\mathrm{O}$ CMI precisa se reinventar. Eu e vários companheiros do CMI estamos falando há muito tempo que ele precisa se reinventar. A gente tem que falar que o CMI foi vítima do seu próprio sucesso, na minha avaliação. Porque o CMI, quando nasceu, teve um milhão de acessos. Imagina: foi uma coisa extraordinária, e a gente adotou aquele modelo, e tem seguido sem mudanças no conceito desde 1999. Já se passaram 10 anos." (Trechos de entrevista com o voluntário Pablo Ortellado. Íntegra no Capítulo 3)

"Eu não mudaria o projeto do CMI. Mas o modo como ele se apresenta para a sociedade, como está sendo distribuído, ainda precisa de alguns ajustes" (Trecho de entrevista com o voluntário Marcelo. Íntegra no Capítulo 3)

“Outra questão essencial para o CMI Brasil, não estou falando da Rede Indymedia, é a reformulação do site (...). E fora refazer o site, tem toda discussão por trás do site: como a gente vai disponibilizar a informação, para quem, de que jeito. $\mathrm{Na}$ verdade, em tudo isso tem uma discussão política." (Trecho de entrevista com a voluntária Foz. Íntegra no Capítulo 3) 
"No início o CMI começou através desse movimento, que aconteceu em Seattle. Depois esse movimento foi tendo uma agenda de manifestações e o CMI foi seguindo essa agenda, e desde o começo a gente sempre colocou que a gente tinha que sair dessa agenda, não só o CMI, mas até mesmo os grupos que participavam do movimento antiglobalização, sempre colocavam que a gente tinha que sair dessa agenda de ação global e começar a ter agendas de questões locais, coisas próprias mesmo, e foi isso mais ou menos o que começou a acontecer. Em um certo ponto, pode-se dizer que mais ou menos em 2004, o CMI começou a se expandir para os movimentos locais, para as pautas locais, para o que estava acontecendo na cidade, o que estava acontecendo na política local, não se esquecendo do que estava acontecendo no resto do mundo, mas se voltando para isso." (Trecho de entrevista com a voluntária Toya. Íntegra no Capítulo 3)

\section{As tarefas principais de framing}

Snow e Benford (1988) identificaram três tarefas de framing cujo nível atingido na realização seria uma das variáveis proporcionais ao sucesso do esforço de mobilização: framing diagnóstico, framing prognóstico, framing motivacional. É na realização satisfatória destas tarefas que os atores resolvem dois problemas-chave: a mobilização de um nível mínimo de consenso, e a mobilização para ação.

- O framing diagnóstico é a tarefa relacionada primeiro à identificação de um problema e, em seguida, à atribuição de culpa ou causalidade em relação ao mesmo. A primeira etapa desta tarefa é mais fácil de cumprir. Já o alcance de consenso em relação a causas e causadores do problema envolve um esforço maior.

- O framing prognóstico é a articulação de uma solução para o problema, bem como de um "plano de ataque" e estratégias para implementação desta solução.

- O framing motivacional, última das tarefas centrais, é a "convocação às armas", ao engajamento e à permanência na luta. Envolve o que Benford (1993) identificou como vocabularies of motive: de severity, urgency, efficacy e propriety. Dependendo de como são construídos, os efeitos de um podem ser até antagônicos ao do outro. 
O principal problema diagnosticado e que move a ação dos participantes do CMI é a falta de cobertura ou a cobertura inapropriada dos movimentos sociais e de assuntos políticos pela mídia. No site americano encontramos uma definição mais geral do alvo da atuação, que pode ser relacionada ao já identificado master frame ${ }^{40}$ de "volta à democracia" (Noonan, 1995, apud Snow 2000), que estaria abalada pela concentração do poder de informar nas mãos das grandes empresas de mídia, comprometidas com seus interesses próprios:

Indymedia is a collective of independent media organizations and hundreds of journalists offering grassroots, non-corporate coverage. Indymedia is a democratic media outlet for the creation of radical, accurate, and passionate tellings of truth. (...) Indymedia endeavors to empower people to become the media by present honest, accurate, powerful independent reports. ${ }^{41}$

O Indymedia é um coletivo de organizações independentes de mídia e centenas de jornalistas oferecendo cobertura em grassroots e não-corporativa. $\mathrm{O}$ Indymedia é um meio de comunicação democrático para a divulgação radical, precisa e apaixonada de histórias verdadeiras. (...) O Indymedia se esforça para capacitar as pessoas a se tornarem a mídia por apresentar relatos independentes honestos, precisos e poderosos. (Noonan, 1995, apud Snow, 2000, tradução e grifos nossos)

A atribuição de causas e, principalmente, causadores (culpados) do problema identificado é parte fundamental do framing diagnóstico. Gamson (1992) sublinha o caráter adversarial dos frames, e a importância de uma noção concreta do "eles" ao qual o "nós" se opõe. Frames de identidade excessivamente inclusivos (como "a humanidade") funcionam mais como um agregado de indivíduos do que como um potencial ator coletivo, e não propõem um "eles" demarcado. Os alvos viram abstrações ("pobreza", "fome", "guerra”, etc.) e fica difícil responsabilizar atores concretos a serem desafiados com ações coletivas também concretas.

\footnotetext{
${ }^{40}$ Certos collective action frames apresentam um largo escopo, funcionando como uma espécie de algoritmo que dá feição e determina as orientações e atividades de outros movimentos. A estes frames "genéricos" Snow e Benford (1992) se referem como master frames, em contraste com os frames específicos dos movimentos, e que podem ser derivados dos master frames.

${ }^{41}$ Frequently Asked Questions (FAQ): http://docs.indymedia.org/view/Global/FrequentlyAskedQuestionEn\#goals. Acesso em 02/11/2009.
} 
A Rede Indymedia e o CMI Brasil trazem um "eles" bem concreto a ser desafiado: os grandes grupos de mídia, que só cobririam aquilo em que têm interesse, e de maneira enviesada. O CMI Brasil também apresenta as corporações em geral e os abusos do Estado como o "eles" a ser combatido.

$\mathrm{Na}$ reunião de apresentação do coletivo a novos voluntários, um dos organizadores explicava a importância de se usar softwares livres. O Estado, representado pelo poder de polícia, aparece como aliado dos interesses conservadores da ordem de tais corporações:

“Temos uma orientação específica de utilizar os softwares livres por dois motivos: primeiro porque são mais seguros, e não é raro nossas ações e comunicações serem monitoradas pela polícia. Certa vez foi combinada e comunicada por email o apoio a uma ação de ocupação de um prédio abandonado pelos sem-teto. Quando chegamos lá já havia dezenas de policiais. Um policial chegou a admitir que sim, estão sempre de olho no que aparece no CMI. E segundo, por uma questão de coerência: não queremos usar as ferramentas comerciais destas megacorporações, como a Microsoft, que são tão prejudiciais e que estamos sempre combatendo." (Fala de voluntário em reunião do coletivo CMI São Paulo)

Também nas notícias publicadas e em emails que circulam pela lista do coletivo de São Paulo encontramos esse antagonismo às corporações e ao sistema capitalista:

“(...) Utilizar então o material mais barato disponível. Esse seria o nosso melhor custo-benefício, talvez. Eu não conheço tecnologia de celular nenhuma quanto à videoprodução, mas não sei se são essas as melhores opções: isso é que deve ser debatido, tendo em vista, antes de tudo, que consumo inteligente também é resistência, como vocês sabem.” (trecho de email da lista do coletivo CMI São Paulo)

“(...) Enquanto o número de famintos aumenta, o lucro assombroso de empresas de alimentação cresce exponencialmente, astronomicamente. De 2006 para cá, só a Cargill, empresa de grãos canadense, elevou seus lucros em mais de 2000\%. O controle do mercado por um punhado de empresas com sede em países como EUA, Canadá, Japão, podendo especular com o preço da alimentação básica da população 
mundial visando apenas o lucro, causa fome a milhões de seres humanos. (...) A própria FAO, organismo da Organização das Nações Unidas para alimentos, reconheceu que a subida dos preços de alimentos - e, portanto, o aumento no número de famintos - vai continuar até pelo menos 2009. (...) Ou acabamos com o capitalismo ou o capitalismo acaba conosco." (trecho de artigo ${ }^{42}$ )

E a mídia corporativa é um dos alvos mais constante das críticas em quase todas as entrevistas.

“É complicado porque, na maior parte das vezes, nós falamos de mídia corporativa, grandes conglomerados de mídia quando se pensa em mídia de massa, comunicação de massa. E aí tem todas as questões, primeiro de não se desafiar o que é o senso comum, o que é estabelecido, então fica sempre em um discurso mediano. Tem a coisa também do famoso 'rabo preso': a mídia está em massa em uma rede de interesse dos mais diversos, e não necessariamente interesses que têm a ver com as camadas da população que têm menos poder de voz - os mais pobres, os LGBT, as mulheres.” (Trecho de entrevista com a voluntária Isadora. Íntegra no Capítulo 3)

"Eu não acredito em jornalismo como comércio, e no conhecimento como uma moeda. É exatamente o que eu não quero, e o jornalismo hoje em dia está todo pautado nisso. São os interesses econômicos e políticos de quem domina aquele meio. Eu desconheço qualquer grande veículo aqui no Brasil que seja autônomo e independente."

"A comunicação corporativa de uma maneira geral é o receptor e o emissor e pronto." (Trechos de entrevista com a voluntária Foz. Íntegra no Capítulo 3)

“A intervenção da direita no Brasil, você pode ver a grande mídia nos últimos anos como vem atuando. Em qualquer artigo, em qualquer meio que você vê sobre o Cesare Batistti, eles se referem a ele como terrorista, ao Hugo Chávez se referem como um ditador, entendeu? Vêm colocando qualquer iniciativa, por exemplo em Honduras, não foi o Zelaya, foi a população que tomou a iniciativa, eles fizeram um referendo, eles coletaram 600.000 assinaturas para pedir aquele referendo, um país

\footnotetext{
42 “Geografia da fome, 2008”: http://www.midiaindependente.org/pt/blue/2008/06/422208.shtml. Acesso em 03/12/2009.
} 
que tem o quê, um pouco mais de 4 milhões de pessoas, 600.000 assinaturas é um número muito grande. Entregaram isso para o Zelaya e ele só fez o referendo por causa disso. Agora você não vê essa informação na grande mídia. Então porque a grande mídia trabalha para direita está acontecendo uma ofensiva muito grande. Em um momento que o Jornal da Band fala que o projeto de direitos humanos no Brasil é o primeiro passo para uma ditadura, sabe, você vê que está rolando uma briga forte no continente entre as duas... a direita e a esquerda." (Trechos de entrevista com a voluntária Toya. Íntegra no Capítulo 3)

O framing prognóstico proposto pelos dois grupos, brasileiro e norteamericano é o mesmo: "Don't hate the media. Be the media", o que quer dizer que os grupos que se sentem prejudicados pela cobertura da grande imprensa devem "arregaçar as mangas" e passarem eles mesmos a produzir as notícias e conteúdos de mídia em geral, principalmente sobre os movimentos sociais, pauta não coberta ou mal coberta pela grande mídia. A ideia implícita é que a circulação de informações sobre propostas, reclamações e protestos dos movimentos é tão importante quanto os protestos em si:

"When's the next protest?

Though Indymedia itself doesn't plan protests, Indymedia ally www.protest.net provides a calendar of upcoming protests and other events."

"Quando é o próximo protesto?

Embora o Indymedia não planeje ele mesmo protestos, seu site parceiro www.protest.net fornece um calendário de protestos programados e outros eventos. $" 43$

Slogans como o citado ("Don't hate the media. Be the media") realizam o framing motivacional, procurando passar a ideia da efetividade de todos atuarem como produtores de conteúdo no desafio ao monopólio dos grandes grupos de comunicação:

\footnotetext{
${ }^{43}$ Idem 41, tradução nossa.
} 
"Acreditamos que dessa maneira estaremos rompendo o papel de espectador(a) passivo/a e transformando a prática midiática".44

O anúncio do evento de lançamento do Indymedia Itália unificado (anteriormente, havia vários coletivos autônomos e desconectados pelo país) traz outro exemplo de slogan do gênero:

“4 de julho - IndYpendence Day. Vocês fazem os planos - nós, a história."45

Além disso, nas entrevistas e comunicações da lista de emails que trazem chamadas à ação encontramos alguns dos vocabularies of motive detectados por Benford: de severity, urgency, efficacy e propriety:

\section{- Eficácia:}

“O que mais me realiza é ver o potencial disso tudo. É ver que o CMI está agora para fazer dez anos, saber que a gente conseguiu mantê-lo vivo por uma década já é uma coisa que me realiza, e também saber do potencial que o CMI tem. O CMI é um dos sites de esquerda mais acessado do Brasil. A gente tem um nível de audiência muito grande, e que dá para aumentar, e conseguir estar mais presente na formação de opinião pública. E também umas coisas pequenas. Tem certas coisas que acontecem no dia-a-dia que você olha e fala: "essa estrutura que fez isso possível. Então você vê em momentos como esse, de uma certa forma, é uma guerrilha midiática, uma estrutura com a qual a gente consegue vencer repressões fortíssimas (...)" (Trechos de entrevista com a voluntária Toya. Íntegra no Capítulo 3)

"Precisamos destes relatos como provas contra as agressões provocadas pela PM [na manifestação do $1^{o}$ de Maio]. Se por acaso você souber de algum companheiro (a) que passou por tais constrangimentos, agressões e ou tortura em cárcere privado pela polícia, por favor, repasse adiante e repasse nas listas libertárias das quais você está presente. SOLIDARIEDADE É UMA ARMA QUENTE!” (Trecho de email da lista do coletivo CMI São Paulo)

\footnotetext{
${ }^{44}$ Idem 12.

45 “O retorno de Indymedia Itália": http://www.midiaindependente.org/pt/blue/2008/07/423497.shtml. Acesso em 03/12/2009.
} 


\section{- Urgência:}

“Olá minha gente... não quero mais só ficar discutindo sobre política... quero é fazer política...” (Trecho de email da lista do coletivo CMI São Paulo)

\section{- Severidade:}

"Isso é super sério, tu ta com os contatos? Vamos agitar, eu estou sem câmera, mas posso conseguir gravador e áudio, mais alguém se anima? O centro da cidade está pegando fogo, começou a operação que cria uma ORGANIZAÇÃO PARAMILITAR PRIVADA no centro de São Paulo, não sejamos ingênuos, vai ser polícia privada defendendo interesses privados. (...) Isso tudo está me tirando do sério, não dá para ficar assistindo de camarote!” (Trecho de email da lista do coletivo CMI São Paulo)

“Gente... muito sério isso, mesmo... é bom ficarmos de olho e, eventualmente, sugerir um editorial, que tal?” (Trecho de email da lista do coletivo CMI São Paulo)

"Acabo de saber de mais dois ambientalistas ameaçados de morte (teve um terceiro que denunciou no CMI, é aquele que tem denunciado a Secretaria de MA de Cubatão). Que tal a gente reativar aquele GT verde? Eu topo ajudar você. Tem muita coisa grave rolando..." (Trecho de email da lista do coletivo CMI São Paulo)

Além da realização com mais ou menos sucesso das tarefas centrais de framing, influencia na efetividade do frame alignment algumas características dos collective action frames elaborados, como veremos.

\subsubsection{Características variáveis dos collective action frames}

O diagrama a seguir mostra a organização das características variáveis dos collective action frames identificadas por Snow e Benford (2000) ao longo dos estudos que adotaram sua perspectiva desde a década de 1980. 


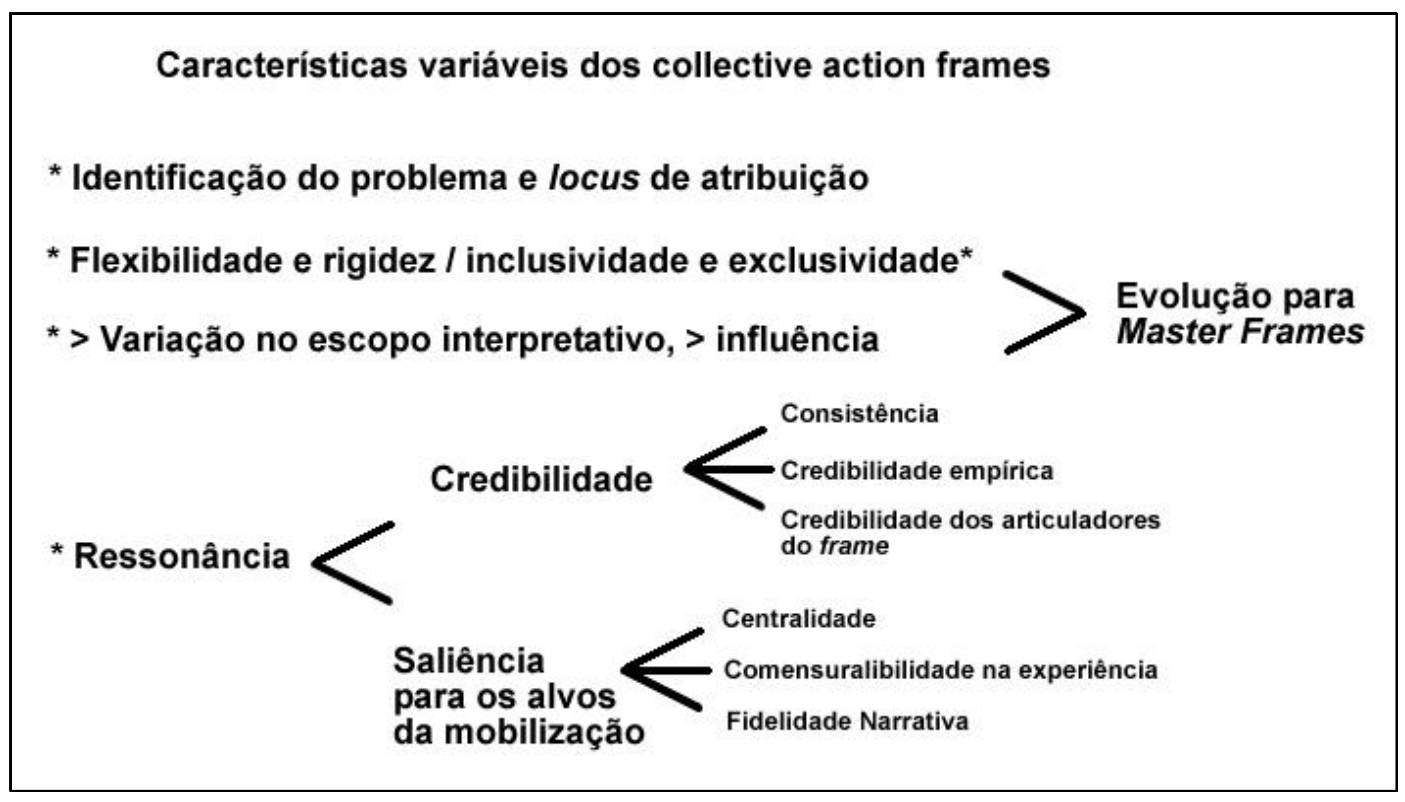

Fig. 4.1 Características variáveis dos collective action frames

Em tese, quanto mais flexível e inclusivo for um collective action frame, será mais provável que ele funcione como ou evolua para um "master frame", já que o escopo de grupos de interesse atingidos é bem maior.

$\mathrm{Na}$ exposição de sua política editorial, o CMI argumenta ser "uma rede anticapitalista de produtores/as de mídia autônomos/as e voluntários/as”. Mas somente dizer que o movimento é anticapitalista poderia afastar aqueles que veem a discussão capitalismo $\mathrm{x}$ socialismo como anacrônica, que não possuem ligação com o movimento operário - que anteriormente comandava esta luta anticapitalista - e que se inserem em lutas consideradas mais pertinentes à contemporaneidade, como a ambientalista e a da defesa de minorias étnicas e sexuais, por exemplo. Por isso, o termo ganha uma definição mais inclusiva:

Anticapitalismo é um termo tradicionalmente utilizado para designar o conjunto das correntes de pensamento e ação que se opõem ao capitalismo, normalmente entendido como o sistema baseado na propriedade privada, na livre concorrência de mercado e no trabalho assalariado. Assim, são considerados anticapitalistas, no sentido tradicional, todas as correntes do socialismo, do comunismo e do anarquismo.

Mais recentemente, o termo anticapitalista foi também utilizado para designar o esforço de convergência das diversas vertentes do movimento social: o movimento ambientalista, o movimento feminista, o movimento operário etc. Este sentido se difundiu principalmente no final dos anos 1990 com o movimento 
de resistência global que buscava reunir esses movimentos que haviam se desenvolvido mais ou menos separadamente a partir dos anos 1960. A utilização do termo anticapitalista neste sentido era um pouco polêmica porque, por um lado, buscava apenas mostrar que os diversos problemas que os movimentos enfrentavam faziam sistema, ou seja, que o desrespeito ao meio ambiente, o sexismo, a hierarquia e a exploração do trabalho estavam arranjados num só sistema - no entanto, não havia consenso entre os movimentos de que o que dava sistematicidade a esses problemas era o capitalismo entendido como sistema econômico. Por isso, nem todos os movimentos acreditavam que o termo anticapitalista era o mais adequado para indicar a convergência.

O Centro de Mídia Independente (CMI) assumiu a denominação de anticapitalista tanto no sentido tradicional (de oposição à propriedade privada, ao sistema de mercado e ao trabalho assalariado) como no sentido mais recente (que remete à convergência dos movimentos). Isso significa que os voluntários do CMI se identificam com o anticapitalismo nas duas acepções. ${ }^{46}$ (Grifos nossos)

Essa redefinição de "anticapitalismo" também funciona como um dos processos de frame alignment já descrito anteriormente - a extensão: aumentar o escopo dos frames interpretativos para que façam sentido para pessoas que não viam nenhuma ligação pessoal com as "causas” do movimento.

Por motivos análogos, o movimento também procura ser flexível quanto à aceitação de participantes:

Isso não quer dizer, no entanto, que o CMI se feche a publicações que não sejam estritamente anticapitalistas. A inclusão do termo anticapitalismo na nossa Política Editorial tem dois motivos:

- Em primeiro lugar, o CMI acredita que ao tornar clara sua orientação anticapitalista, ele contribui para uma comunicação que não se propõe neutra ou objetiva, mas que acredita que a maneira mais honesta de contribuir para a informação do público é deixar claro o ponto de vista de onde se fala;

- Em segundo lugar, ao assumir a denominação anticapitalista, o CMI quer deixar mais claro que o espaço de publicação aberta não é um espaço destinado àqueles que professam e defendem posições políticas contrárias às do CMI, ou seja, pró-capitalistas. Isso, no entanto, não impede que grupos com posições políticas intermediárias ou sem posição política definida publiquem livremente, desde que o conteúdo não seja pró-capitalista ou que não viole os

\footnotetext{
${ }^{46}$ Definição de anticapitalismo: http://www.midiaindependente.org/pt/blue/static/anticapitalismo.shtml.
} Acesso em 12/11/2009. 
outros itens da Política Editorial (que proíbe racismo, sexismo, ofensas pessoais, propaganda comercial ou partidária, pregação religiosa, entre outras coisas). ${ }^{47}$

Influenciando na ressonância, temos a credibilidade geral do frame, formada pela consistência, juntamente com a credibilidade de quem articula o frame (que pode ser o movimento como grupo ou os seus organizadores individualmente) e a credibilidade empírica do mesmo - aparente ajuste entre o frame e os eventos no mundo (Snow e Benford, 2000).

Em busca desta credibilidade, percebemos que o movimento procura mostrarse coerente com os valores que assume. No CMI Brasil, onde o viés libertário é mais acentuado do que o do movimento de origem norte-americana, faz mais sentido uma moderação mais flexível dos conteúdos que chegam. O máximo que se faz é deslocar os conteúdos em desacordo com a política editorial para a seção "artigos escondidos", também chamada de "lixo aberto", onde ainda ficam acessíveis.

Além disso, tanto nas entrevistas quanto durante o nosso período de convivência com membros do CMI em São Paulo, estes participantes deixaram claro como buscam viver em suas vidas pessoais e como grupo as bandeiras defendidas pelos principais movimentos que o projeto abrange. Em primeiro lugar, uma política baseada na autogestão envolve todas as ações e decisões do grupo, baseadas no consenso, e sem liderança ou hierarquia.

Como abordamos no início do capítulo, os eventos organizados e a manutenção do espaço Ay Carmela!, que abriga vários coletivos de diferentes movimentos, incluindo o CMI São Paulo, tem bem forte esta característica autogestionária. Também, a defesa da preservação ambiental se mostra presente nos diálogos e posturas dos participantes. Em eventos festivos que acompanhamos, há todo um cuidado com o lixo e com a economia de água. Muitos dos voluntários são também adeptos do uso da bicicleta, e críticas à chamada "cultura do automóvel" são sempre tema nas conversas. Alguns participam da "Bicicletada", iniciativa inspirada em movimento iniciado nos Estados Unidos que reivindica espaço nas ruas para os ciclistas, promovendo passeios ciclísticos e protestos.

Do mesmo modo, como boa parte dos voluntários de São Paulo está envolvida com o movimento Fórum Centro Vivo, pela democratização dos espaços e pelo direito das populações de baixa renda de permanecerem no centro da cidade, procura-se dar

\footnotetext{
${ }^{47}$ Idem 46.
} 
espaço para os moradores do entorno do espaço Ay Carmela! (que também fica no centro) participarem de suas atividades, tornando o mesmo um espaço aberto e democrático.

Apesar de não ser "pré-requisito" para participar do CMI, e nem a totalidade de seus participantes adotarem este estilo de vida, o vegetarianismo - motivado principalmente pela defesa da libertação animal e do chamado "antiespecismo" - faz parte do cotidiano do grupo. O menu de todos os eventos comemorativos, mostras de vídeos e shows não inclui carne: feijoada vegetariana, paella vegetariana, comida mexicana preparada com soja, etc.

Mas a ocasião mais exemplar da busca de congruência entre o que se fala e como se age (e sempre que há oportunidade, os membros do CMI contam o episódio com um certo orgulho) envolveu toda a Rede Indymedia, em particular o CMI Argentina: a recusa de uma grande soma de dinheiro - 50 mil dólares - que a Fundação Ford desejava destinar ao grupo. Após acaloradas discussões, chegou-se ao consenso de que o dinheiro seria inconveniente, já que vindo de uma corporação cujas atividades (e mesmo o simples caráter de empresa capitalista multinacional) eram justamente o alvo das ações de vários dos movimentos que o CMI abrange. Curiosamente, a Fundação financia no Brasil um outro grupo, constituído em ONG, que tem como objetivo principal a democratização da mídia: o coletivo Intervozes ${ }^{48}$.

Burguer (2004, p. 42-43) descreve detalhadamente o processo de debate que culminou na decisão de barrar a doação.

O CMI Argentina conseguiu barrar a proposta transformando a discussão em um tango - sofrido e dramático. Segundo os ativistas, receber esse dinheiro seria uma desonra ("quem recebe subsídio dessa fundação é apontado como traidor), acarretando na "morte" do coletivo portenho ("não seria correto sacrificá-lo no altar das corporações"). Ao se negar a receber mesmo "um tostão dessas mãos que estão sujas com o sangue de nossos camaradas", foi adiada uma importante oportunidade em direção à exploração de novas possibilidades na

\footnotetext{
${ }^{48}$ Pode-se argumentar que a ONG é uma dissidência do CMI, menos focalizada na questão dos movimentos sociais e luta "anticapitalista" e mais no direito à comunicação: "O Intervozes - Coletivo Brasil de Comunicação Social, constituído juridicamente em 2003, é uma organização que luta com base na compreensão de que a comunicação é um direito humano. Sem o direito à comunicação não existe democracia e a palavra cidadania transforma-se em mera retórica. Sem o direito humano à comunicação, os outros direitos não se efetivam. Nesse sentido, a comunicação de que falamos não pode ser compreendida como arena de especialistas. É terreno de cada cidadão, de qualquer lugar do planeta. A ampliação radical da sociedade civil na definição das políticas de comunicação é, portanto, um dos nossos objetivos." (http://www.intervozes.org.br/o-intervozes. Acesso em 12/08/2008)
} 
comunicação em rede. (...). Embora não sejam contra a política de doações, e mesmo "necessitando delas com toda a urgência", eles têm em vista a importância ("por demais transcendental") do CMI para a reunião dos movimentos naquele país; e por isso mesmo, "não seria direito arriscá-la por uns trinta dólares".

Diante da possibilidade real de colapso do coletivo portenho, e da própria ameaça disrupção da rede, o julgamento mudou radicalmente, e a maior parte das opiniões foi contra a aceitação da subvenção. A maioria das mensagens reitera a solidariedade à opinião "traumatizada" dos argentinos, acrescentando que não vale a pena "envenenar a rede" por causa de uma doação. Mais importante é manter sempre os canais de comunicação abertos ao diálogo, e que prevaleça a liberdade de expressão, o livre debate de idéias e o respeito pela opinião alheia.

A ressonância de um frame, entretanto, não varia apenas com sua credibilidade geral, mas também com a sua saliência para os alvos da mobilização, decomposta em três dimensões: centralidade, comensurabilidade na experiência e fidelidade narrativa.

A centralidade mede o quão essenciais as crenças associadas aos frames do grupo ou movimento são nas vidas dos alvos da mobilização. Conforme sublinhamos, o moto original de CMI e Indymedia é a quebra do monopólio da mídia. Entretanto, em ambos temos cobertura de fatos e temáticas específicas de certos movimentos sociais, que conforme apuramos após acompanhamento das postagens durantes três meses, no site brasileiro concentram-se problemas sociais em geral, problemas ambientais, movimento pela libertação animal, direitos de minorias étnicas e sexuais, política em geral, política nacional, política internacional (América Latina, EUA, Oriente Médio e Europa), democratização da mídia, movimento estudantil, e movimento sindical.

Esta variedade, apresentada como característica do movimento antiglobalização (o "movimento dos movimentos") atua de três formas. Em primeiro lugar, é maior a possibilidade de que um destes vários temas goze de centralidade na vida de um potencial participante do que se se focalizassem poucos assuntos. Além disso, o participante atraído à rede pela sua "temática preferida" tem contato com outras temáticas e outros movimentos pelos quais pode se interessar, ou pelo menos estabelecer o laço de "estamos todos no mesmo barco e na mesma luta" - o que também é uma das ações de frame alignment: a ligação (frame bridging). 
Ainda, qualquer visitante do site depara-se com inúmeras notícias de ações de movimentos sociais diversos, e dificilmente sai de lá com a impressão (se a tinha antes) de que predomina um consenso pacífico e passividade entre os grupos sociais marginalizados. A fala de um dos organizadores em uma reunião ilustra que esta última função é conscientemente pretendida:

"Nossa ideia é dar voz a quem não tem, principalmente aos movimentos sociais. Queremos também desmistificar essa ideia de que no Brasil nada acontece, de que o brasileiro é um povo passivo. Tem sim muitos movimentos acontecendo e muita repressão rolando em cima deles.” (Fala de voluntário em reunião)

Gamson (1992) destaca a predominância de uma espécie de "culture of quiescence", a crença de que a cultura política atual continuamente reforça a valorização das atitudes individuais, e desmotiva as pessoas a se engajarem na ação coletiva. Contudo, seu estudo empírico sobre conversações a respeito de temas políticos mostrou que, mesmo sem serem incentivados pelos pesquisadores, mais de $80 \%$ dos grupos pesquisados tocaram na questão da participação nos processos sobre os quais conversavam, demonstrando espontaneamente um senso de agency. Estimular a visibilidade dos movimentos de relativo sucesso que já acontecem e que não são noticiados na grande mídia pode então ser uma estratégia fundamental para transformar o senso de agency presente na população em real engajamento.

Mas a variedade não atua só no sentido de fortalecer o movimento, pois o abrigo de temáticas tão diversas entre si também pode favorecer visões conflitantes entre os participantes, como mostram as respostas dadas em entrevista por uma ativista do CMI em relação às questões abaixo:

"Eu sou originária de dois movimentos: o de direitos humanos e o ambientalista. Fiz parte do Greenpeace e de outras ONGs. Só que eu saí do movimento ambientalista porque, em geral, os participantes são muito despolitizados. Então se colocam a falar contra os quilombolas e contras os indígenas, e daí meu 'racha' com eles. Você tem que saber exatamente quem degrada o meio-ambiente e, ao contrário do que se pensa, os ricos degradam muito mais do que os pobres. Então, eu também não aceito este discurso de que os indígenas destroem o meio ambiente. Ainda discuto as questões ambientais, mas desde que elas sejam coerentes. Quando 
começa um discurso truncado de que 'índio é problema para parque', eu paro e digo: 'Não. Desculpe, mas o parque é que é problema para índio'.”

"Eu sofri reações de antissemitismo no grupo anterior do CMI. Não era todo o grupo nem era a maioria, mas eu fiquei muito machucada e saí. O brasileiro tem esse problema de, quando lida com a questão do Oriente Médio, colocar o árabe como coitadinho e o judeu como monstrinho - e não é assim. Tem radicais dos dois lados, baixarias como morte de crianças dos dois lados. Se você fosse uma judia morando num kibutz, sem fazer mal para ninguém, e esfaqueassem seus filhos, você ia pensar: será que todos os árabes são tão bonzinhos assim? Ou o pessoal que não tem conhecimento e defende, sem saber, os califados, a alta burguesia, que os próprios árabes falam: 'pelo amor de deus, não defendam nossos opressores!' Existe terrorismo dos dois lados, e mesmo que o terrorismo de Estado seja ainda mais condenável, e que a população palestina seja mais vulnerável, não dá para dizer que a população civil de nenhum dos lados tenha que conviver com isso." (Trecho de entrevista com a voluntária Miryám Hess. Íntegra no Capítulo 3)

O diálogo a seguir, entre duas voluntárias do CMI, retirado da lista de emails do coletivo editorial, também exemplifica conflitos afins.

"A gente tem tido varias publicações [postagens na coluna da direita do site do CMI] dos tais 'Gays de Direita'. Têm site e tudo e reclamam da repressão contra os homossexuais em locais como Cuba e China. Deixamos? Ou [mandamos para o] lixo aberto? Olhem o exemplo:

http://midiaindependente.org/pt/blue/2009/09/454573.shtml" (Trecho de email da lista do coletivo CMI São Paulo) 


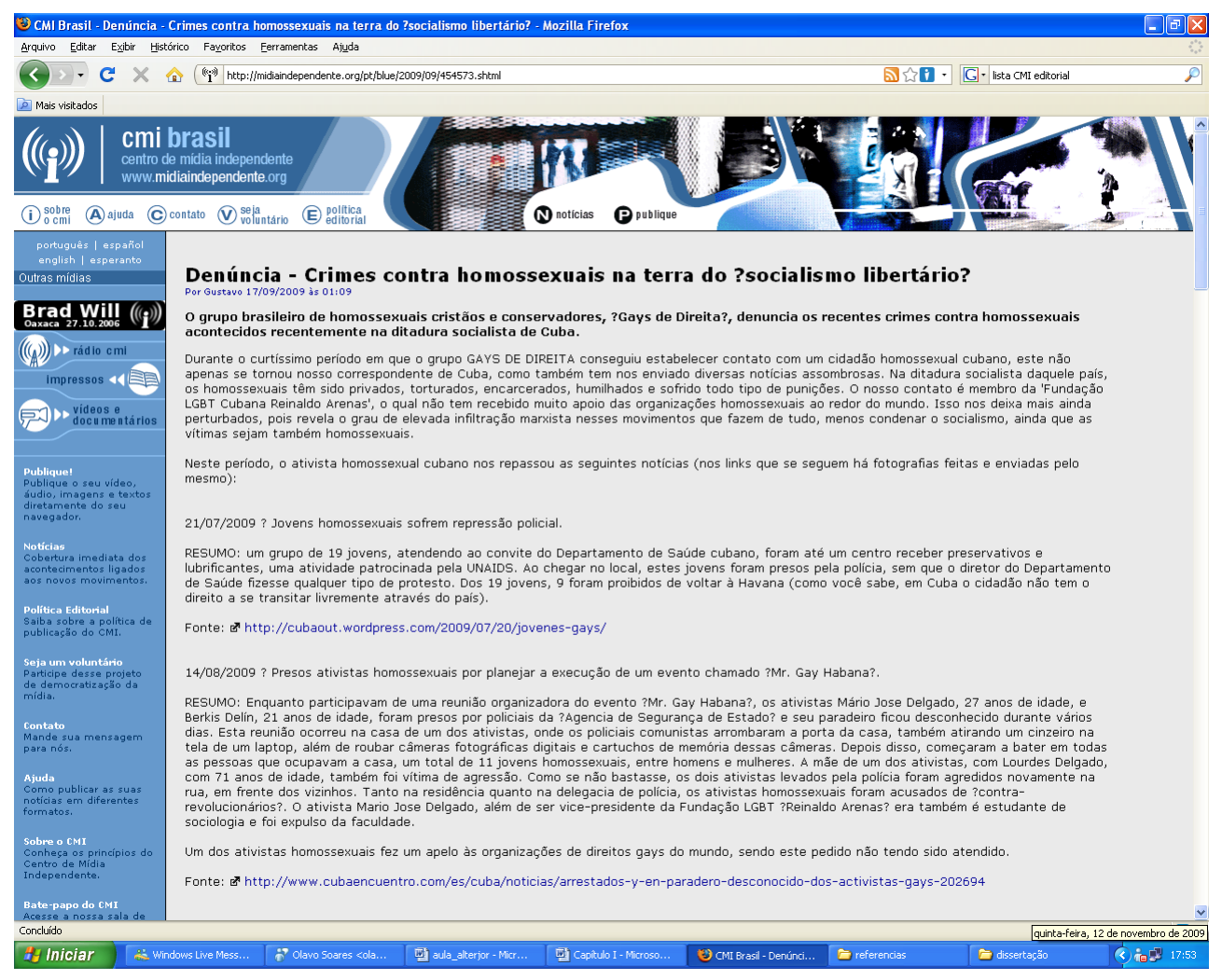

Fig. 4.2 http://midiaindependente.org/pt/blue/2009/09/454573.shtml. Acesso em 12/11/2009

“É complicado, eu deixaria os posts. Casos de homofobia existem no mundo inteiro e é preciso combater isso. Só que enquanto os 'Gays de Direita' estão super preocupados com Cuba, deveriam preocupar com a violência homofóbica no Brasil. Já que no último mês saiu uma pesquisa e o Brasil esta como o país mais violento para gays.” (Trecho de email da lista do coletivo CMI São Paulo)

De qualquer maneira, os frames construídos pelos organizadores da Rede Indymedia e do CMI, conforme evidenciados nesta breve análise, têm conseguido mobilizar um grupo grande de participantes por mais de uma década (ver Tab. 2.1 no Capítulo 2), tanto para a própria rede quanto para os movimentos sociais diversos de que ela trata. 


\subsection{Práticas: ativistas, jornalistas}

Conforme já assinalamos, pela perspectiva da mobilização de recursos acrescida da dimensão cultural, significados, crenças, ideias, práticas, valores, mitos e narrativas são parte de um "toolkit" e podem ser mobilizados para os fins de grupos e movimentos sociais, modelando - intencionalmente ou não - novos elementos culturais e novas molduras interpretativas. Assim, não só a análise das entrevistas realizadas com os voluntários do CMI e de suas falas e mensagens de email, como feito anteriormente, mas também a observação e reflexão sobre suas práticas permitem caracterizar traços do perfil deste grupo.

\subsubsection{Ativismo}

Em primeiro lugar, surge a noção de ativista, seja pela ótica de quem entrevistou seja pela maneira como os entrevistados se analisam, emergindo direta ou indiretamente esta autoconsciência.

A difícil definição deste conceito, até pelo fato do termo ser relativamente recente, não nos exime de um esforço neste sentido. Assis (2006, p.14) chega a uma noção que também parece adequada a este trabalho:

(...) [o ativista político] é um "radical" envolvido em ações políticas diretas e indiretas sempre fora do âmbito institucional. É "mais" que um militante - participa de um grupo, segue seus ideais, mas também vai às ruas e cria situações de confronto com seus alvos - e "menos" que um revolucionário suas ações não buscam remodelar o sistema de poder vigente de forma impositiva. $\mathrm{O}$ ativista é um agente engajado, movido por sua ideologia a práticas concretas - de força física ou criativa - que visam desafiar mentalidades e práticas do sistema sócio-político-econômico, construindo uma revolução a passos pequenos.

Esclarecedoras também são as ideias de coletividade e transgressão, trazidas de Jordan:

Ativismo é essencialmente algo feito em conjunto por muitas pessoas, mas devemos ser cuidadosos com o sentido de grupo ou coletividade empregado aqui. O que é essencial ao ativismo não é simplesmente haver mais do que uma 
pessoa, como em um cinema, mas um sentido de solidariedade em busca da transgressão. Deve haver um sentido de identidade compartilhada, que pode ser entendido nesta etapa como pessoas reconhecendo, umas nas outras a raiva, o medo, a esperança ou outras emoções que sintam quanto a uma transgressão. (Jordan, 2002, pp. 11-12 apud Assis, 2006, p.13)

Assim, a transgressão está ligada ao desafio de uma ordem que, por um elenco variável de motivos, gera um sentimento de indignação - traço identitário que compartilham - e que se dinamiza, resultando em ações. Mas, nos movimentos contemporâneos, prevalece um tipo particular de ação: a ação direta, que dá um sentido mais específico à noção de ativismo. A ação direta (que inclusive era o nome de um jornal impresso produzido no início dos anos 2000 pelo CMI) se distancia das esferas institucionais - como é o caso da política realizada no plano eleitoral ou o recurso único ao sistema judiciário - para se aproximar do cotidiano e presente. Enfim, "a ação direta é a manifestação na rua, a greve, o boicote, a sabotagem - qualquer ação positiva (fazer algo) que tenha implicações concretas, e geralmente imediatas, sobre seus alvos." (Assis, 2006, p.14) Exemplos práticos nos são dados na fala de um dos voluntários entrevistados, bem como uma menção a outro termo afim, a "desobediência civil".

“[Ação direta $]$ é algo que o CMI faz, assim como alguns movimentos sociais. O movimento dos sem-teto, por exemplo: tem um prédio há dez anos desocupado, e um monte de gente com necessidade de morar em algum lugar... Eles vão lá e ocupam. O CMI, quando fez o protesto lá na Avenida Roberto Marinho, uma intervenção urbana, renomeando a avenida para 'Vladmir Herzog”... Eu mesmo colei quatro placas. Então é você fazer esta intervenção direta no meio público (...) Outra terminologia associada a isso é o que chamamos de desobediência civil. As leis são construídas por um grupo de pessoas que não representam a sociedade, feitas principalmente para este grupo de pessoas - e se não estão nos atendendo vamos lá e subvertemos mesmo, desobedecemos. Há, por exemplo, até uma juíza federal, em relação ao movimento de rádios livres, que escreve: desobedeça, faça a rádio livre. (...) Então, rádio livre é outra forma de ação direta." (Trecho de entrevista com o voluntário Marcelo. Íntegra no Capítulo 3) 
Além da ação direta, a relação dos ativistas dos movimentos recentes com os meios de comunicação é outro capítulo característico em sua história. E mais do que as ações voltadas para a mídia, como é o caso, por exemplo, de grupos ambientalistas como Greenpeace e WWF, que organizam protestos estrategicamente planejados para a repercussão midiática, trata-se aqui de apropriação direta da mídia. Ainda que até a década de 1960 jornais, panfletos e fanzines da cultura alternativa proliferassem, Azzi (2007, p. 129) observa corretamente que

(...) por mais subversiva que tenha sido a geração dos anos 1960, ela parece não ter sido capaz de se apropriar dos meios de comunicação de nenhuma forma parecida com esta realizada pela jovem geração do Indymedia. Pelo contrário, sua aversão às tecnologias de comunicação constitui uma diferença qualitativa da postura com relação às possibilidades positivas que poderia haver num uso político alternativo destes instrumentos.

Desde a popularização da internet, portanto, esta característica do ativismo contemporâneo se acentuou, ao ponto de ter sido cunhado o termo "ciberativismo". Se atualmente todos os grupos ativistas fazem uso da rede para articulação, comunicação e penetração, para alguns a meta é a vida na própria rede.

Entende-se por ciberativismo a utilização da Internet por movimentos politicamente motivados (Vegh, 2003, p.71), com o intuito de alcançar suas tradicionais metas ou lutar contra injustiças que ocorrem na própria rede. (Gurak, Logie, 2003; MCCaughey, Ayers, 2003).

\subsubsection{Jornalistas}

\section{Jornalismo open source ou cidadão}

Se o escopo de ações realizadas pelo grupo de voluntários do CMI não se limita à internet, esta é meio na quase totalidade delas, e fim em alguns casos. Mas o principal uso que dela fazem é a troca e divulgação de informações, colocando a comunicação em primeiro plano. Fica claro no discurso das entrevistas que os voluntários sabem - mesmo participando em paralelo de outros grupos de movimentos com outros tipos de ações - que a atuação por excelência desenvolvida como participantes do CMI faz parte do campo da comunicação e da mídia. E mídia, em sua 
visão, aparece estreitamente vinculada com o jornalismo. Apesar da indústria fonográfica, cinematográfica, da música e do entretenimento, como parte de um todo, também serem criticados e a produção e divulgação independente destes produtos serem incentivadas como prática política ${ }^{49}$, sãos empresas jornalísticas, veículos, grande imprensa e os jornalistas profissionais em si o alvo maior da crítica que a Rede Indymedia realiza, e que propõe desafiar a partir da assunção por eles mesmos do papel de jornalistas. Mais do que ciberativistas, poderíamos então chamá-los de "midiativistas" Mas já existem alguns outros conceitos que, bem delimitados para o caso em questão, podem dar conta de caracterizá-los a respeito desta prática.

Referimo-nos aqui à noção de jornalismo cidadão, também conhecido como colaborativo, ou open source. É o jornalismo praticado, em geral no ambiente online, por indivíduos comuns, isto é, não jornalistas profissionais, ou mesmo jornalistas profissionais fora dos meios de comunicação instituídos. Open source é uma referência às comunidades inaugurais no uso das redes informáticas para trabalho colaborativo, que foram os programadores dos softwares livres, de código aberto. $\mathrm{O}$ código destes programas é revelado, permitindo a qualquer programador a readequação dos mesmos às suas necessidades, e a sua melhoria, visando (no caso dos projetos gratuitos e voluntários, já que existe mais de uma modalidade de software livre) não o lucro, mas o bem da comunidade de usuários, em um trabalho coletivo e colaborativo desenvolvido em rede.

\footnotetext{
${ }^{49}$ Afirma Francisco Berardi, em entrevista a Fernandéz-Savater, sobre o fenômeno mais geral do midiativismo:
}

"La comunicación no es un instrumento de la acción política, sino la acción política misma. En primer lugar, el espacio social se construye cada vez más por medio de la proyección mediática de escenarios. La producción de imaginario es, además, un sector decisivo del proceso general de trabajo. Los productores de imágenes son una parte de los trabajadores cognitivos. Por tanto, la producción mediática independiente es, ante todo, un fenómeno de autoorganización del trabajo semiótico. En las experiencias de software libre, de open source y de P2P (peer to peer) no debemos ver sólo una innovación técnica o relacional. En esas experiencias hay indicios de un posible proceso de autonomía del cerebro colectivo frente a la estandarización capitalista".

“A comunicação não é um instrumento de ação política, mas uma ação política em si. Em primeiro lugar, o espaço social é cada vez mais construído por meio de cenários de projeção de mídia. A produção de imagens é também um setor crucial do processo de trabalho global. Os produtores de imagens são uma parte dos trabalhadores cognitivos. Portanto, a produção de mídia independente é essencialmente um fenômeno de auto-organização do trabalho de semiótica. Nas experiências de software livre e de código aberto P2P (peer to peer), não devemos ver apenas uma inovação técnica ou relacional. Nestas experiências, há indícios de um possível processo de autonomia do cérebro coletivo contra a padronização capitalista." (Fernandéz-Savater, 2005, tradução e grifos nossos) 
Um exemplo é o sistema operacional Linux, que em março de 2010 contava com aproximadamente 125 mil programadores e projetistas cadastrados ${ }^{50}$, trabalhando voluntariamente em algum projeto. A colaboração é feita através da internet, envolvendo grande número de desenvolvedores, e assim a qualidade técnica do sistema conquista novos usuários, entre os quais muitos se tornam testadores e desenvolvedores do sistema, o que contribui ainda mais para a qualidade técnica, em um círculo virtuoso que atrai mais desenvolvedores e permite a melhoria "infinita" do programa.

Manuel Castells assim comenta o sucesso deste processo de produção:

Só uma rede de centenas de milhares de cérebros trabalhando cooperativamente, com divisão do trabalho espontânea, e coordenação maleável, mas eficiente, poderia levar a cabo a tarefa extraordinária de criar um sistema operacional capaz de lidar com a complexidade de computadores cada vez mais potentes interagindo por meio da Internet. (Castells, 2003, p.41).

A modalidade cidadã, colaborativa, ou open source de jornalismo tem em comum com a de softwares a reunião de uma comunidade de pessoas separadas fisicamente, mas conectadas pela internet e trabalhando por um objetivo comum. Além disso, como acontece com o código-fonte no caso dos softwares, para qualquer usuário, aqui a "caixa secreta" da produção de notícias é aberta aos não-profissionais. Mesmo que a participação nos meios jornalísticos de não profissionais para fins nãocomerciais não seja inédita $^{51}$, é dos anos 1990 em diante, com a comunicação por meios digitais, que essa possibilidade se amplia. Qualquer um com acesso aos meios ainda restritos, mas ao menos em termos de internet e produção de vídeos, um pouco mais democráticos - e as competências linguísticas e técnicas mínimas exigidas para a produção e divulgação de uma notícia deste modo pode fazê-lo.

\footnotetext{
${ }^{50} \mathrm{O}$ contador de programadores disponível em http://counter.li.org indica apenas os que se registraram. E a organização estima, baseada em um fórmula explicada em http://counter.li.org/estimates.php, que o número real de usuários é de cerca de 29 milhões. Acesso aos sites em 23/03/2010.

${ }^{51} \mathrm{O}$ jornalismo cidadão não é tão recente quanto se pensa: há mais de duas décadas atrás, por exemplo, o brasileiro Juarez Maia coordenou em Moçambique um a produção de um jornal para camponeses. $\mathrm{O}$ jornal começou com quatro páginas, metade delas dedicada às cartas de leitores. Em dois anos, $O$ Campo passou a ter 16 páginas, todas com cartas. Os editores se deram conta de que o conteúdo trazido por leitores era bem mais interessante do que as reportagens feitas por um pequeno número jornalistas que nem conheciam o local (Castilho, 2004). Mas foi com a internet que figura do cidadão-repórter ganhou novas dimensões, porque ela agilizou a interação entre jornalistas e público e difundiu os antes restritos meios de publicação.
} 
Busca-se inverter a ordem emissor-receptor, pois não há necessariamente papéis fixos, onde um lado é mais ativo do que o outro. Na já largamente celebrada "web 2.0" (já se fala até em "web 3.0" desaparecem, mas têm que se reavaliar, pois passam "a conviver com outros múltiplos mediadores que têm à disposição o mesmo espaço de produção e distribuição de informações utilizado pelos profissionais da comunicação". (Sandano, 2007)

Um exemplo conhecido da prática do jornalismo open source é o jornal online sul-coreano Oh My News ${ }^{53}$, objeto de pesquisa de Brambilla (2005, p. 104)

De Seul, mais de 40 países atendem à proposta do noticiário online coreano OhmyNews de que cada cidadão seja um repórter. O bordão anunciado pelo jornalista Oh Yeon Ho, em 2000 - ano da criação do site -, insere-se num espírito global de horizontalização do processo comunicacional midiático através de ambiente digital. Na capital coreana, mais de 40 mil pessoas aderiram à idéia de serem cidadãos repórteres.

A concepção de citizen reporter para Oh Yeon Ho, vai além da participação na redação de artigos e publicação em um site noticioso. Não se trata de uma tática, conforme aponta o jornalista, mas de uma filosofia. Oh Yeon Ho fala de um modelo de pensamento que visa transformar a sociedade através da mídia, guiando-se por ideais libertários viabilizados por uma orientação editorial interativa, o que, na sua opinião, baliza um jornal na Internet com alto nível de interação. "Existem dois níveis de interatividade na produção e no consumo de notícias. O baixo e o alto. O baixo nível de interatividade acontece quando repórteres profissionais escrevem e os leitores mandam email ou postam comentários em murais. Então o que é o alto nível de interatividade? Neste processo, repórteres e leitores são iguais. Leitores podem se tornar repórteres a qualquer hora que ele ou ela quiserem.” (Oh, 2005, p.4 apud Brambilla, 2005, p. 108)

A filosofia se assemelha à da Rede Indymedia, que foi criada anteriormente, ao propor uma cobertura multilateral, menos superficial, não enviesada, e mais calcada no interesse da população do que nos ganhos financeiros ou interesses particulares. Mas há diferenças importantes a considerar, e que vão além da forma de gestão e do

$52 \mathrm{O}$ artigo de John Markoff em uma edição de novembro de 2006 do jornal The New York Times traz pela primeira vez o termo. http://noticias.uol.com.br/midiaglobal/nytimes/2006/11 Acesso em 01/02/2010.

${ }^{53}$ http://english.ohmynews.com. Página internacional, em inglês, do veículo. Acesso em 01/02/2010. 
bem elaborado sistema de moderação e edição do jornal coreano. A que mais nos interessa aqui se refere à temática. Enquanto Oh My News mantém uma estrutura de conteúdos em editorias que em parte se assemelha às dos jornais online da grande mídia $^{54}$, na Rede Indymedia em geral, e em particular no caso do CMI Brasil, que ora estudamos, o que ganha destaque é a temática dos movimentos sociais, seja por meio de análises e textos opinativos, seja pela a cobertura jornalística propriamente dita de ações destes movimentos, incluindo as referidas ações diretas.

É nesta cobertura, com maior ou menor consciência disto variando de voluntário a voluntário ${ }^{55}$, que os participantes se tornam jornalistas cidadãos, assumindo - sem ter que atender às rotinas de produção para o mercado nem às exigências de uma organização privada - eles mesmos a função de gatekeepers $^{56}$, como observa Leal (2007, p.122):

Contudo, observando que a fonte de produção da notícia no CMI Brasil é, na realidade, o cidadão, verificamos que o portão, o filtro, mudou de lugar. Mudou para o cidadão que resolve o quê, quando e onde publicar. Mudou para o sujeito social que, ao verificar fatos que merecem relevância, merecem visibilidade, resolve ter a iniciativa de fazê-lo, ou seja, decide divulgar o que considera de interesse social. O que se reflete na política editorial do CMI Brasil,

\footnotetext{
${ }^{54}$ As editorias do OhmyNews International incluem "Notícias", com Coreia, Mundo, Ciência e Tecnologia, Arte e Vida, Entretenimento, Esportes, "Global Watch", Entrevistas, e Podcasts; e "Opinião", com Colunistas e Fórum. O acesso ao site no dia 23/03/2010, por exemplo, trazia entre as "Today's top stories" a matéria "Formula Indy Races To Brazil" ("Fórmula Indy corre para o Brasil"), a respeito da primeira corrida do gênero realizada no país. A abordagem da matéria não trazia nada de muito diferente da vista nos veículos convencionais.

http://english.ohmynews.com/ArticleView/article_view.asp?menu=A11100\&no=386003\&rel_no=1\&b ack_url= Acesso em 23/03/2010.

\begin{abstract}
${ }^{55}$ Alguns voluntários citaram nominalmente o termo jornalismo cidadão, dizendo que é o que o CMI pratica há vários anos, e que é colocado agora como se fosse algo novo.

"Então é um espaço aberto, de um termo que está sendo muito usado agora, mas que a gente já vem fazendo há uma década, que é o jornalismo cidadão. Da pessoa estar contando a sua própria história. Então é jornalismo sim, no momento em que uma pessoa senta e escreve uma história, conta um fato, ela está relatando um acontecimento não deixa de ser, eu acho que é justamente esse termo que estão usando muito agora, mas que a gente sempre vem fazendo, jornalismo cidadão. Inclusive, só para completar, hoje em dia a própria mídia corporativa vem se pautando na produção de informação por pessoas comuns. Por exemplo, você vê a CNN, a CNN vive falando 'saiu isso no Twitter, saiu aquilo no Twitter'. A Folha de São Paulo, no caderno de informática, sempre tem ali, mas lógico que eles também fazem uma filtragem, vão pegar aquelas publicações ou de pessoas famosas, ou de algumas pessoas que estão no local do acontecimento do momento. Por exemplo, tem pessoas no Haiti agora, eles vão pegar notícias dali. Agora eles estão começando a fazer o que a gente sempre fez, lógico que eles estão fazendo de forma diferente.” (Trechos de entrevista com a voluntária Foz. Íntegra no Capítulo 3)
\end{abstract}

${ }^{56}$ Conceito introduzido na década de 1950 na teoria do jornalismo por David Manning White, que prioriza a ação pessoal do jornalista-autor na filtragem do que deve ou não ser notícia. (Kunczik, 2001, p. 241). 
que prioriza notícias advindas dos movimentos sociais ou sobre matérias de interesse destes.

Na expressão “jornalismo cidadão”, “cidadão” não é palavra para só designar a generalidade das pessoas que podem participar a da atividade, isto é, sem necessidade de profissionalização específica naquela área. O jornalismo se transforma de fato em um exercício da cidadania por parte destes voluntários, por meio da comunicação alternativa à grande mídia praticada pelo CMI e dos movimentos sociais que nele são tema.

Em linhas gerais, o conceito de cidadania definido com base nos direitos do homem pressupõe igualdade de todos perante a lei; domínio de todos sobre seus corpos e suas vidas; acesso das pessoas a salários que atendam suas necessidades; direito a serviços básicos de educação, saúde, habitação e lazer; e direito à expressão livre das ideias e crenças, bem como à participação tanto na política institucional quanto em sindicatos e movimentos sociais.

Conforme nos lembra Manzini-Covre (1995, p. 10), tudo isso depende em larga medida "do enfrentamento político adotado por quem tem pouco poder". Ou seja, "Só existe cidadania se houver a prática da reivindicação, da apropriação de espaços, da pugna para fazer valer os direitos do cidadão" (Idem, p. 10), tanto os civis, quantos os sociais e os políticos ${ }^{57}$, e aqui encontramos uma relação incontestável do

\footnotetext{
${ }^{57}$ Os direitos civis surgem nas sociedades ocidentais para regular a economia de mercado. Uma de suas organizações de interesses exemplares é a dos consumidores. São também direitos que se organizam contra o Estado, para que este não invada nem impeça que as pessoas exerçam suas atividades econômicas. Ou seja, em sua origem, são sobretudos direitos burgueses e precisam ser atualizados para incorporação de quem está de fora deste grupo. Vale uma citação elucidativa: "A evolução, no interior de cada sociedade, dos direitos civis em direção à sua incorporação efetiva para todos depende, portanto, de movimentos complexos, pressões de baixo, na perspectiva clara de preservá-los enquanto valores universais mas, no próprio processo de alargamento, da produção de uma efetiva mudança qualitativa". (Gentilli, 2005, p.99)

Os direitos políticos tratam do acesso de todos os cidadãos à vida política de sua nação, e têm origem a partir de uma nova concepção de representação surgida na Revolução Francesa. Mais até do que no caso dos direitos civis, os direitos políticos pressupõem a necessidade de incorporação para todos, já que em vez de protegerem o cidadão do poder do Estado, propiciam mecanismos para participação no poder de Estado. Os direitos sociais entram em foco principalmente no século XX, consagrados no chamado estado de bem-estar social. Em alguns casos surgem como consequência de lutas e movimentos reivindicatórios; em outros como antecipação preventiva do Estado a eles. São tanto direitos de dignidade e bem-estar material, como cultural. Uma característica importante destes direitos é que só é necessária a sua existência e garantia pelo Estado porque as desigualdades da economia capitalista impossibilitam o acesso de cidadãos de certas origens sociais aos mesmos. Daí o fato de um autor como Victor Gentilli classificar os direitos civis como antagônicos aos sociais, já que "atendem a interesses diversos da sociedade, de maneira desigual" (Gentilli, 2005, p. 106).
} 
conceito de cidadania com o de movimentos sociais. Se a noção moderna de cidadania surgiu com a ascensão da cultura burguesa, com a valorização do trabalho, e do modo de produção capitalista, as transformações neste regime econômico também trouxeram novas ameaças a diversos direitos, particularmente quando se pensa nas desigualdades sociais que de saída produz. Mesmo com suas transformações na época contemporânea, percebemos que mudam as modalidades, mas a exploração e alienação de direitos básicos de grupos mais fracos persistem. Se na Europa o Welfare State (que dava ao Estado a prerrogativa de fazer com que estes direitos fossem cumpridos) foi desmontado, em países como o Brasil ele nem chegou a existir. Nosso processo de modernização não chegou a se completar em todas as áreas e ainda lidamos com os problemas sociais que uma política arcaica gera (Martins, 1997, p. 81).

É, pois, patente a relevância para a cidadania e a atualidade dos movimentos de contestação, com também da comunicação para a contestação, mesmo em uma era que pode ser chamada de a "era dos direitos" $"$. São estes, então, o foco do jornalismo cidadão que o CMI pratica.

\section{A mídia sobre e dos movimentos sociais como mídia alternativa}

A comunicação dos movimentos sociais, como de qualquer atividade coletiva humana, sempre foi uma das práticas essenciais para o alcance dos seus objetivos. Dos cartazes em piquetes e nos postes, aos panfletos e jornais semi-artesanais, passando pelos fanzines, a revistas e jornais de produção mais "profissional", grupos que

\footnotetext{
${ }^{58} \mathrm{O}$ autor do termo explica a situação: "A maior parte dos direitos sociais, os chamados direitos de segunda geração, que são exibidos brilhantemente em todas as declarações nacionais e internacionais, permaneceu no papel. O que dizer dos direitos de terceira e de quarta geração? A única coisa que até agora se pode dizer é que são expressão de aspirações ideais, às quais o nome de "direitos" serve unicamente para atribuir um título de nobreza. [...] Não se poderia explicar a contradição entre a literatura que faz a apologia da 'era dos direitos' e aquela que denuncia a massa dos 'sem-direitos'. Mas os direitos de que fala a primeira são somente os proclamados nas instituições internacionais e nos congressos, enquanto os direitos de que fala a segunda são aqueles que a esmagadora maioria da humanidade não possui de fato (ainda que sejam solene e repetidamente proclamados)." (Bobbio, 2004, p.41)
}

"Não se pode pôr o problema dos direitos do homem abstraindo dos dois grandes problemas de nosso tempo, que são os problemas da guerra e da miséria, do absurdo contraste entre o excesso de potência que criou as condições para uma guerra exterminadora e o excesso de impotência que condena grandes massas humanas à fome. Só nesse contexto é que podemos nos aproximar do problema dos direitos com senso de realismo. [Quem ler a Declaração Universal e depois olhar em torno de si] será obrigado a reconhecer que, apesar das antecipações iluminadas dos filósofos, das corajosas formulações dos juristas, dos esforços dos políticos de boa vontade, o caminho a percorrer é ainda longo.” (Idem, pp. 2021) 
desejam subverter algum estado de coisas precisam se comunicar bem entre si, num movimento de articulação interna, e também com o restante da sociedade (como visto sobre a construção de seus frames) para quem necessitam expor suas motivações, denúncias e ideias para a mudança.

Estudando a comunicação praticada fora do âmbito comercial, e que propõe subversões do estado social e político, Downing (2002) recusa a adoção somente da terminologia "mídia alternativa", preferindo "mídia radical alternativa". Atribui a esta instância papel e potencial essencialmente ligados a esta ideia de mudança e, em certo sentido, de cidadania. Mas destaca, principalmente, sua relação com os movimentos sociais.

A mídia radical alternativa serve como agente do poder de desenvolvimento em inúmeros sentidos. Sem idealizá-la [...], ela é muito mais essencial à democracia do que tendem a reconhecer os comentaristas embasbacados com o alcance e a influência facilmente visível da mídia oficial. (Downing, 2002, p.80)

Em primeiro lugar, a mídia radical alternativa expande o âmbito das informações, da reflexão e da troca a partir dos limites hegemônicos, geralmente estreitos, do discurso da mídia convencional. Isso se dá, em parte, pelo fato de ser bastante numerosa. Em segundo lugar, ela freqüentemente tenta ser mais sensível do que a mídia convencional às vozes e aspirações dos excluídos. Muitas vezes, tem estreita relação com algum movimento social em andamento e, portanto, expressa com muita espontaneidade os pontos de vista e opiniões que não encontram espaço ou são ridicularizados na mídia oficial. Com muita frequiência também, é ela que toma a dianteira na discussão de questões que só mais tarde receberão atenção da mídia oficial. Em terceiro lugar, a mídia radical alternativa não precisa censurar-se para atender aos interesses dos mandachuvas da mídia, do entrincheirado poder estatal e das autoridades religiosas. Em quarto, sua própria organização interna é muitas vezes mais democrática que hierárquica [...]. E, finalmente, algumas formas de mídia radical cumprem o papel inovador que Raymond Williams atribuía ao que ele denominava 'formações' [com influência significativa na cultura e uma relação geralmente oblíqua com as instituições formais]. Estes elementos combinados justificam plenamente a idéia de que a mídia radical é o agente da capacidade de desenvolvimento, não apenas instituições de contra-informação e, com certeza, não um enfadonho enxame de mosquitos passageiros. (Downing, 2002, p.81) 
No Brasil, os ativistas dos grupos que criticavam o regime ditatorial das décadas de 1960-1970 encontravam nas chamadas publicações alternativas - mesmo que muitas vezes fortemente censuradas - o principal espaço de reorganização política e ideológica das esquerdas nas condições específicas do autoritarismo.

Nos períodos de maior depressão das esquerdas e intelectuais, cada jornal funcionava como pólo virtual de agregação no ambiente hostil e desagregador da ditadura. Pode-se traçar, assim, uma demarcação entre imprensa convencional e imprensa alternativa no Brasil pelos seus papéis opostos como agregadores ou desagregadores da sociedade civil, em especial dos intelectuais, jornalistas e ativistas políticos. (Kucinski, 1990, p. XXII)

Descrevendo desfecho do surto alternativo dessas décadas, Bernardo Kucinski explica que, a partir de 1980, o engajamento entre o jornalismo e a política basista se deslocou predominantemente para órgãos de sindicatos e partidos políticos, e para os jornais de movimentos populares, apoiados pela Igreja Católica e outras entidades da sociedade civil, com uma outra geração engajada e uma ética prevalecente bem diferente. Aqui o jornalista não era mais sujeito do processo, e desaparecia a autonomia jornalística.

Se a história comprovar a morte da utopia, é possível que o desaparecimento quase total e repentino da imprensa alternativa tenha sido premonitório, corroborando a tese de que essa imprensa, por estabelecer pontes entre organizações e a sociedade, antecipa as grandes transformações. Nesse caso, por raciocínio inverso, podemos entender o próprio surgimento da imprensa alternativa dos anos 70 como uma das últimas grandes manifestações da utopia no Brasil. Estimulado pelo surgimento da ditadura, mas com direito próprio de existência na história. (Kucinski, 1990, p. XXIX)

Se concordarmos com o autor de que o fim da ditadura não explica por si só o declínio desta imprensa alternativa - já que a mesma possuía uma existência e importância autônomas -, não podemos, por outro lado, assumir sua suspeita sobre o fim da utopia em território nacional, isto é, do sonho de emancipação e justiça social por meio de uma prática política oposta à vigente. É certo que esta imprensa alternativa específica e datada à qual ele se refere era uma de suas manifestações, no bojo de uma década de rebeldia, em que movimentos por mudanças aconteciam em todo mundo. Mas também é pouco crível que tenha sido a última. 
A imprensa alternativa não teve lugar somente em países marcados pela ditadura militar, mas em qualquer lugar em que houvesse algo a contestar que não fosse tratado na imprensa convencional. $\mathrm{E}$ - mesmo que com ondas mais ou menos ativas e numerosas - contestadores nunca faltaram. Países de situação histórica tão diversa da nossa quanto Estados Unidos e Inglaterra abrigaram e abrigam este tipo de comunicação nas eras moderna e contemporânea:

In the 1960 an alternative press once again began to emerge, this time informed not so much by a 'plebeian' consciousness as by a range of 'social movements'. (Harcup, 2003: 358) From diverse background, a hundred small Davis emerged to challenge - or simply to mock - the press Goliath. Technically, this dissident press ranged from professionally produced and printed journals to roneoed sheets, and in its contents mirrored a wide range of protest movements large and small. Its unifying cause was the rejection of the media themselves.

Em 1960 uma imprensa alternativa mais uma vez começou a surgir, desta vez, alimentada não tanto por uma consciência 'plebeia' mas por uma série de 'movimentos sociais'. (Harcup, 2003: 358) De diversos contextos, uma centena de pequenos Davis surgiu para contestar - ou simplesmente para zombar - da imprensa Golias. Tecnicamente, esta imprensa dissidente variava de jornais impressos e produzidos profissionalmente a folhas mimeografadas, e o seu conteúdo refletia uma ampla gama de movimentos de protesto, grandes e pequenos. Sua causa unificadora era a rejeição da própria mídia. (Harrison, 1974, apud Harcup, 2003, p. 358, tradução nossa)

Também os movimentos sociais, ainda que com diferentes motivações e repertórios, desde sempre existiram - e se se tornaram mais fortes e explícitos em tempos de forte repressão baseada na violência física (que por sinal não recuou totalmente), isto não significa que deixaram ou deixarão de existir em todo o mundo. No caso do Brasil, o que houve foi uma reacomodação e mudança de foco - que por um tempo chegou a fazer crer no seu desaparecimento - de movimentos rebeldes e de publicações alternativas após o fim de um regime militar, diante do surgimento de novas necessidades.

Um exemplo de reformas que pode ser incluída sob o signo da política, e que ficou por ser feita por completo mesmo após a chamada abertura, é o efetivo acesso 
plural aos meios de comunicação. Isso porque a comunicação permeia todos aqueles requisitos básicos para a participação democrática que Wilson Gomes (2005, p. 59) resgatou de Bucy e Gregson:

a) um volume adequado de conhecimento político estrutural e circunstancial, um estoque apropriado de informações não distorcidas e relevantes, suficientes para habilitar o cidadão a níveis adequados de compreensão de questões, argumentos, posições e matérias relativas aos negócios públicos e ao jogo político;

b) possibilidade, dada aos cidadãos, de acesso a debates públicos já começados e possibilidade de iniciar novos debates desta natureza, onde a cidadania deveria exercitar a oportunidade de envolver-se em contraposições argumentativas, de desenvolver seus próprios argumentos, de envolver-se em procedimentos deliberativos no interior dos quais pode formar a própria opinião e decisão políticas;

c) meios e oportunidades de participação em instituições democráticas ou em grupos de pressão - mediante ações como voto, afiliação, comparecimento a eventos políticos ou através de outras atividades políticas nacionais ou locais;

d) habilitação para e oportunidades eficazes de comunicação da esfera civil com seus representantes (em níveis local, nacional ou internacional) e para deles cobrar explicações e prestação de contas.

Robert Park (Park, 1976, apud Gentilli, 2005, p. 141) destaca a conceituação da notícia jornalística como intimamente ligada à história e à política sem corresponder a nenhuma delas, e também como o material que possibilita a ação política. São então necessárias pressões populares para que não haja entraves no exercício e efetivação do potencial que o jornalismo, em teoria, traz. Umas das questões preocupantes, por exemplo, que precisa ser resolvida, é a dos monopólios de meios de comunicação, já que estes limitam seriamente o escopo do acesso que o cidadão tem às informações. O que acontece é que, após a abertura, os jornais e emissoras de rádio e televisão não sofreriam mais o peso do braço direto da censura militar, mas tampouco passariam a representar mais satisfatoriamente a sociedade. É conhecida nossa tradição de posse familiar dos grandes grupos de mídias, desde os regionais (RBS na Região Sul do País, afiliadas da Rede Globo espalhadas pelo País, como a Globo baiana), até os de nível nacional (Grupo Abril/família Civita, Rede Globo/clã Marinho), muitas destas famílias ligadas aos interesses mais conservadores, como os do setor ruralista, do qual fazem parte, e com seus membros em 
envolvimento direto na política, exercendo cargos eletivos mesmo com a explícita proibição por lei dessa atividade paralela. ${ }^{59}$

Assim, se no plano geral estas duas instâncias (movimento social e comunicação alternativa ou, se preferida a terminologia de Downing, radical alternativa) estão imiscuídas, também o estão na prática do CMI.

Os movimentos sociais constituem uma das expressões mais dinâmicas de resistência, em comparação com instituições mais estáveis e duradouras, como sindicatos ou partidos. São de enorme importância para a compreensão da mídia radical e das culturas de oposição. A ascensão desses movimentos parece ocasionar e, ao mesmo tempo, ser ocasionada, pela ascensão da mídia radical. De modo inverso, na época em que esses movimentos refluem, o fluxo da mídia também diminui. Mas a questão não termina aí. Bem entendida, a relação entre os movimentos sociais e a mídia radical não é uma relação de base e superestrutura, mas de forte interdependência dialética. (Downing, 2002, p.55)

O exercício da comunicação, como temos afirmado, é não só uma necessidade dos movimentos sociais como parte integrante das reivindicações de mesmos. E os voluntários do CMI estão entre os principais grupos que, no Brasil, agem neste sentido: tanto protestando pela democratização dos meios por meio de ações e publicações sobre o assunto, quanto agindo diretamente na produção de conteúdo informativo e jornalístico que privilegia os atores que reivindicam mudanças: os movimentos.

Nesta medida, podemos sim visualizar a prática dos voluntários do CMI Brasil como jornalismo alternativo, ou, em um termo mais includente, mídia alternativa. E podemos certamente - ainda que haja diferenças que vão além do suporte predominante (impresso versus online) - ver alguns aspectos de continuidade em relação ao momento de maior expansão desta atividade no país, que foram as mencionadas décadas de 1960 e 1970.

\footnotetext{
59 De acordo com dados do projeto "Donos da Mídia", do Instituto de Estudos e Pesquisas em Comunicação (Epcom), dos 27 partidos políticos registrados no Tribunal Superior Eleitoral (TSE), 20 estão representados por políticos como proprietários de veículos de radiodifusão. Os políticos do DEM ficam em primeiro lugar com, 58 veículos, e representam $24,1 \%$ do total da classe sócia de meios de comunicação. Os filiados ao PMDB vêm em segundo, com 48 veículos (17\% do total), seguido dos membros do PSDB, com 43 canais de TV ou rádios. (Costa, 2008). Apesar de elucidativa, a pesquisa deixa de fora as ligações não oficiais entre os dois grupos (a prática dos "laranjas", e do "tráfico de influência", por exemplo), que poderiam revelar um quadro vertiginosamente mais grave.
} 
Para esta época anterior, Kucinski (1990) identifica duas classes de imprensa alternativa. A primeira composta por jornais predominantemente políticos, marcados pela valorização do nacional e do popular dos anos 50 e pelo marxismo. Dogmáticos e didáticos, pois estavam em pauta os movimentos populares, temas clássicos das esquerdas, táticas de oposição e presença marcante do Partido Comunista. E a segunda dos jornalistas que recusavam a primazia do discurso ideológico.

Mais voltados a crítica dos costumes e a ruptura cultural, tinham suas raízes nos movimentos de contra-cultura norte-americanos e, através deles, no orientalismo, no anarquismo e no existencialismo de Jean Paul Sartre. Investiam principalmente contra o autoritarismo na esfera dos costumes e o moralismo hipócrita da classe média (Kucinski, 1990, p. XV).

Se o combate à ditadura e às suas políticas era um dos maiores focos da imprensa alternativa daquele período, ainda que as ações e o pensamento de esquerda como um todo fossem contemplados, na mídia produzida pelo CMI os movimentos sociais envolvidos são outros, mas não é eliminada a característica principal que nos faz classificá-la como mídia alternativa, que é a reivindicação por mudanças e a relação intrínseca com outros grupos que se movimentam por mudanças. Expressar o desejo de romper com um estado de coisas, propor outros modelos políticos e sociais.

O conceito de Kucinski (1990) para "imprensa alternativa" e o de Downing (2002) para "mídia radical alternativa" apontam semelhanças, em particular quanto aos objetivos de ambas, mesmo que o primeiro se volte para um contexto específico.

(...) o radical de alternativa contém quatro dos significados dessa imprensa: o de algo que não está ligado a políticas dominantes; o de uma opção entre duas coisas reciprocamente excludentes; o de uma única saída para uma situação difícil e, finalmente, o do desejo das gerações dos anos 60 e 70, de protagonizar as transformações sociais que prezavam. Opunham-se por princípio ao discurso oficial” (Kucinski, 1990, p. XIII).

(...) a mídia radical alternativa geralmente serve a dois propósitos precedentes: a) expressar verticalmente, a partir dos setores subordinados, oposição direta à estrutura de poder e seu comportamento; b) obter, horizontalmente, apoio e solidariedade e construir uma rede de relações contrária 
às políticas públicas ou mesmo à própria sobrevivência da estrutura de poder.

(Dowing, 2002, pp.29-30)

Mesmo que não toquem explicitamente na questão dos movimentos sociais, outras definições de "alternativo/a" no contexto midiático incluiriam certamente o CMI. Vejamos as definições de imprensa alternativa reunidas por Chris Atton em seu ensaio "A reassssment of the alternative press" (1999):

1. The publisher has to be non-commercial, demonstrating that 'a basic concern for ideas, not the concern for profit, is the motivation for publication'.

2. The subject matter of their publications should focus on 'social responsibility or creative expression, or usually a combination of both'.

3. Finally, it is enough for publishers to define themselves as alternative publishers.

1. O editor tem de ser não-comercial, demonstrando que 'uma preocupação básica a respeito de ideias, e não com o lucro, é a motivação para a publicação'.

2. O tema das publicações deve focalizar responsabilidade social, expressão criativa, ou, como usual, uma combinação de ambos.

3. Finalmente, é suficiente que os editores se definam como editores alternativos. (Alternatives in Print, 1980, apud Atton, 1999, p.51, tradução nossa)

[I]t is not the established order; it is not the capitalist system; it is not the mainstream view of a subject...; or it is simply not the conventional way of doing something.

Não é a ordem estabelecida, não é o sistema capitalista, não é a visão dominante de um assunto...; ou, simplesmente, não é a maneira convencional de se fazer algo. (Comedia, 1984, apud Atton, 1999 , p.51, tradução nossa)

1. An alternative publication deals with the opinions of small minorities;

2. it expresses attitudes 'hostile to widely-held beliefs';

3. it 'espouses views or deals with subjects not given regular coverage by publications generally available at newsagents.

1. Uma publicação alternativa lida com opiniões de pequenas minorias;

2. Ela rechaça opiniões do senso comum; 
3. Ela adota pontos de vista ou lida com assuntos sobre os quais não é dada cobertura regular nas publicações geralmente disponíveis em bancas de jornal. (Royal Comission on The Press, 1977 apud Atton, 1999, p.51, tradução nossa)

The aim is to change towards a more equitable social, cultural and economic whole in wich the individual is not reduced to an object (of the media or the political powers) but is able to find fulfilment as a total human being.

A meta é a transformação para um quadro social, cultural e econômico mais justo, em que o indivíduo não seja reduzido a um objeto (da mídia ou o do poder político), mas seja capaz de encontrar realização como um ser humano total. (Traber, 1985, apud Atton, 1999, p.52 tradução nossa)

Em relação à definição de objetivo de Michael Traber, trata-se da preferida de Atton, justamente por enfatizar as ações políticas e sociais em sobreposição até mesmo à comunicação de fatos e opiniões. Apesar de também atender aos primeiros critérios listados, o CMI ajusta-se melhor a este conceito, pois pode-se dizer que as mudanças de cunho sócio-político, na variedade de causas pelas quais os movimentos noticiados lutam, são a meta, funcionando a comunicação alternativa praticada como um modo de contribuir para seu alcance.

E é quando Atton comenta explicitamente a questão da conexão do veículo com movimentos sociais que encontraremos em algumas características do CMI um modelo ideal para a mídia alternativa. Ao sugerir o emprego do conceito de "esfera pública alternativa" para justificar por que o baixo número de leitores fora do "gueto" ou a pequena duração no tempo de uma publicação não eram critérios suficientes para aferir o fracasso de uma mídia alternativa, o autor afirma ser vital a relação da imprensa alternativa com os grassroots movements que ela apoia e aos quais se refere.

Indeed, many alternative media are inseparable from their social and political actualization (as movements). Commenting on the underground press in the USA, an anonymous writer in the CIA remarked: "It would appear that the vitality of the alternative press was directly proportional to the health of the radical movement in general. The underground arose from the ferment of the times $[\ldots]$ ".. 
De fato, muitos meios de comunicação alternativos são inseparáveis de sua atualização social e política (como movimentos). A respeito da imprensa clandestina nos EUA, um escritor anônimo na CIA comentou: "Parece que a vitalidade da imprensa alternativa foi diretamente proporcional à saúde do movimento radical, em geral. O underground surgiu do fermento da época [...]" (Atton, 1999, p.56, tradução nossa)

E relembrando o autoproclamado caráter anticapitalista do CMI, para o jornalista inglês Eamonn McCann, um projeto de mídia que de alguma maneira, mesmo que informalmente, não se conectasse a um esforço mais abrangente para derrubar o capitalismo, não era de maneira alguma alternativo. (McCann, 1999, apud Harcup, 2003, p.358)

Mas a comunicação livre, além de um meio para fortalecer os diversos movimentos, é também um fím para o qual se direciona a manutenção do veículo online de participação aberta e o menos controlada possível.

Além de autofinanciado, o CMI é, por definição, apartidário. Os criadores do veículo e quem o mantém o declaram anticapitalista, mas nem por isso o inserem em algum grupo político específico, ou institucionalizado, como é o caso dos partidos. Então aqui não temos uma espécie de "instrumentalização" da comunicação pelos partidos de esquerda como foi o caso de muitas das publicações descritas por Kucinski, e que em alguns casos representou a ruína das mesmas, pelos embates partidários e pela desagregação em torno de um projeto maior que o processo causava. Há sim discussões sobre que temáticas priorizar em que momentos, e sobre a maneira de comunicar eventos, mas tudo isto é feito de uma maneira organizada e consensual, prevalecendo nas disputas - como observamos durante o acompanhamento da lista editorial - as opiniões consideradas mais bem argumentadas. É possível também que influencie a aceitação dessas opiniões quem as proferiu: mas não pelo fato de estas pessoas serem líderes oficiais, e sim por disporem do maior capital social: o respeito da comunidade, que neste caso é conquistado principalmente pelo tempo de dedicação e nível de engajamento nos empreendimentos do coletivo.

Dentro da mesma definição referida anteriormente, Traber também distingue duas modalidades de imprensa alternativa, a primeira sendo a advocacy press (que traduziremos como imprensa engajada), que adota uma perspectiva de valores oposta à da mídia de massa, trazendo à cena atores sociais alternativos como pobres, oprimidos, marginalizados, jovens, mulheres e crianças. Estes não aparecem mais 
apenas como observadores, comentadores marginais dos eventos, ou destacados como personagens com a marca do conflito e do bizarro.

Quanto à segunda, a grassroots press - a que mais tem a ver com o CMI, e preferimos não traduzir para evitar imprecisão -, ela vai mais além na subversão dos valores da mídia convencional, pois modifica o próprio processo de produção da notícia e seus atores.

[I]t is the grassroots press that offers the most thoroughgoing version of alternative news values. It is produced by the same people whose concerns it represents, giving a position of engagement and direct participation. This need not to preclude the involvement of professionals, but they will be firmly $\mathrm{n}$ the role of advisors; their presence being to enable the "ordinary people" to produce their own work, independent of professional journalists or editors. This is to propose a model of the Alternative media that goes well beyond the left-liberal, reformist construction of the alternative advocacy press.

A imprensa grassroots é a que traz a versão mais aprofundada dos valores dos noticiários alternativos. Ela é produzida pelas mesmas pessoas cujas preocupações representa, promovendo engajamento e participação direta. Isto não necessariamente exclui o envolvimento dos profissionais, mas estes aparecem no papel de consultores, e sua presença vem para habilitar as "pessoas comuns" a produzirem seu próprio trabalho, independentemente de jornalistas profissionais ou editores. Isso é para propor um modelo de mídia alternativa que vá muito além da construção de esquerda, liberal e reformista da imprensa alternativa engajada (Traber, 1985, p.3 apud Atton, 1999, tradução e grifos nossos)

No CMI, nem mesmo o papel de aconselhamento ("consultores") dos jornalistas profissionais que Traber cita é visto como necessário. Há sim, jornalistas profissionais participando da iniciativa, como se viu principalmente nos eventos de Seattle que deram início ao site, mas sua presença ou não varia muito de coletivo regional para coletivo, e os mesmos não exercem nenhum papel de liderança - até porque "liderança" é uma palavra pouco afeita da maioria dos participantes, que afirmam ter tendências libertárias e/ou anarquistas. 
São pessoas comuns, como na conceituação de Traber, que mantêm o site em funcionamento. Mas não se trata de jornalismo popular ${ }^{60}$, pois não é uma regra que os próprios atores escrevam sobre sua realidade. São os participantes de movimentos sociais ou simpatizantes dos mesmos que fazem isso. Não é o mais comum, embora possa ocorrer, encontrar, por exemplo, um sem-teto ou um camponês do MST produzindo conteúdo para o CMI, ou então os próprios índios escrevendo sobre sua situação. Mas a questão indígena e a das reformas agrária e urbana, bem como outras de cunho social, permeiam boa parte dos artigos. Quando os próprios atingidos pela situação são os que a denunciam através do site, em geral estes atingidos têm nível educacional e de inclusão digital que propicia a publicação do conteúdo: participantes e simpatizantes de movimentos por igualdade racial, feministas ou defensores dos direitos dos animais e do meio-ambiente, por exemplo - movimentos que não envolvem necessariamente exclusão econômica e da educação formal dos atingidos pelas questões abordadas.

Para resumir, rigorosamente, qualquer um pode publicar e ser um jornalista cidadão, embora somente os não atingidos pelas limitações de acesso à internet e domínio da comunicação escrita o façam. Mas mesmo estes, ao menos encontram espécies de porta-vozes - os jornalistas cidadãos voluntários do CMI que cobrem os movimentos sociais - para levar suas informações e reivindicações para o mundo virtual, ainda que mais filtradas e mediadas do que seriam se pudessem trazê-las diretamente.

\footnotetext{
${ }^{60}$ Pelo menos de acordo com o conceito de popular que aqui adotamos, que são as publicações que se identificam apenas com o terceiro tipo entre os determinados por Carlos Eduardo Lins da Silva (1986) em sua definição desta modalidade de veículo:

“1. aqueles que defendem as classes trabalhadoras, mas estas não os produzem nem são os destinatários principais;

2. aqueles que defendem os interesses das classes trabalhadoras, sendo estas os destinatários principais, mas não são elas quem o produzem;

3. aqueles que defendem os interesses das classes trabalhadoras, são por elas produzidos e a elas se destinam." (Lins da Silva, 1986, p.63) - e acrescentaríamos "minorias" ao lado de "classes trabalhadoras" nos três tipos.

Deste modo, todo jornalismo popular ou comunitário seria alternativo, mas nem todo jornalismo alternativo seria popular.
} 


\section{Considerações finais}

Estudando o perfil do grupo de usuários da coluna da direita do site, que não necessariamente são voluntários em outras tarefas do CMI - e, como vimos ser o caso, em sua maioria não são - cremos que a pesquisa mais pontual, realizada por questionários fechados e à distância, ainda que não tenha podido captar toda riqueza de individualidades e visões de mundo, represente ainda assim um importante instrumento para identificar algumas características recorrentes entre quem utiliza a seção totalmente aberta do site para postar conteúdo.

Apesar de termos colocado algumas observações, baseadas na constatação de certos atributos dominantes entre tais usuários (como sexo, região e nível educacional), nossa intenção foi mais de demonstrar do que explicar, deixando a segunda tarefa a cargo da reflexão dos próprios organizadores do CMI, e talvez de futuras pesquisas com este foco específico.

A exceção aqui está na constatação de um certo desconhecimento da proposta e do histórico do CMI entre tais usuários. Usuários que não só não fazem parte do grupo de voluntários (o que, a rigor, não impediria tal conhecimento), como também nunca frequentaram reunião ou evento nacional ou de algum coletivo local, e nem participam de alguma das listas de emails, onde se pode acompanhar e entender com mais precisão como funciona o CMI. Dizemos exceção porque tal constatação já era uma suspeita da pesquisadora ao ler variadas postagens fora da política editorial ou da proposta do site - e esta foi inclusive uma de nossas motivações ao realizar a pesquisa com os usuários da coluna da direita. Assim, confirmar estatisticamente o que se observava há algum tempo dá maior margem ao estabelecimento de hipóteses explicativas para o fato, quais sejam:

- Por ser uma mídia alternativa, o CMI, ainda que entre veículos afins tenha destaque, podendo sem prejuízo ser dito que ocupa a primeira posição (em acessos e "nome"), não é conhecido do grande público. Público este que, mesmo que se interesse por política e jornalismo (como parece ser o caso destes usuários), não está tão a par dos movimentos sociais contemporâneos e de suas formas de se comunicar. Nem mesmo entre alunos e pesquisadores de jornalismo o site é assim tão difundido, como pudemos observar em eventos 
dos quais participamos voltados a esta parcela, e nos quais sempre era necessário contar a história do CMI e mostrar o site antes de apresentar nossa pesquisa, já que a maioria da plateia nunca tinha ouvido, ou tinha ouvido apenas vagamente falar do mesmo, sem nunca tê-lo acessado. Os usuáriosprovedores em questão, como supomos (não há rastreio e nem investigamos isso na pesquisa), caem em conteúdo do CMI por meio de buscas diversas na internet, ou mesmo têm a visita recomendada, mas concentram-se no ato da postagem pura e simples, pouco refletida em relação ao site em que estão postando, isto é, com pouco interesse em conhecer o que está por trás dele e as regras - mesmo em uma iniciativa de caráter autonomista elas existem - que o regem.

- Inclusive entre os usuários-provedores que conhecem há mais tempo o CMI e/ou fazem parte de movimentos sociais, é possível que a proposta do CMI não esteja tão clara assim. Não basta a presença de um link com a política editorial - embora acreditemos que uma melhoria desta seção, com um histórico mais completo da iniciativa e detalhamento de seu funcionamento fosse de grande valia. A própria pesquisadora demorou bastante para entender como funcionava de fato o coletivo, e cremos que até hoje não o tenhamos apreendido em sua totalidade, nem mesmo a totalidade objetiva e palpável à qual nos referimos, que é a estrutura de funcionamento da grande rede global do qual faz parte.

- Seriam, em nossa opinião, necessários mais eventos de apresentação do CMI para os movimentos sociais e demais grupos da sociedade, ou a participação com este propósito em eventos que não são unicamente do CMI. Passaram-se dez anos, mas pode ser que a organização do veículo carregue em seu imaginário a ideia de que ele já esteja suficientemente consolidado (como diz Pablo Ortellado na entrevista do Capítulo 3, é "vítima de seu próprio sucesso"), dispensando tais esforços de prospecção de público e de novos voluntários. Embora essa necessidade tenha inclusive aparecido em uma das entrevistas literalmente, e em outras indiretamente, se a crença da urgência desta tarefa realmente prevalecesse, mesmo com a deficiência de voluntários face ao grande número de tarefas que a manutenção do projeto exige 
(deficiência essa apontada por vários integrantes), a prioridade identificada a faria sair da intenção. Inclusive porque um círculo virtuoso se formaria: o projeto mais bem conhecido e difundido - mais voluntários interessados em participar - mais voluntários para realizar as tarefas e para divulgar o projeto o projeto mais bem conhecido e difundido, e assim sucessivamente.

$\mathrm{O}$ mesmo podemos dizer em relação às estatísticas de certos assuntos e formatos de postagem - apenas as demonstramos. Mas é possível fazer uma exceção para o caso da categoria política - geral $^{61}$, e do formato texto opinativo ${ }^{62}$, sem formato jornalístico. Já notávamos as presenças constantes de tal categoria e tal formato, e a pesquisa somente as referendou. Assim, com uma reflexão mais extensa sobre esta constatação, estabelecemos aqui algumas hipóteses, que também apareceram, às vezes marginalmente, e em outras diretamente, em algumas entrevistas nas quais buscamos levar os participantes as refletirem sobre o assunto. São elas:

- O fato de os usuários-provedores não conhecerem o CMI e sua proposta também pode servir, como nos itens anteriores, para explicar a grande quantidade de postagens neste formato e com este assunto.

- Uma outra explicação está no fato de que, ainda que entre os voluntários se considere que boa parte da prática efetuada no projeto possa qualificá-lo como jornalístico, pouco se reflete sobre o que seja jornalismo um fazer que, mesmo sem a necessidade do caráter profissional pelo CMI combatido, tem sua estrutura própria e certos parâmetros estabelecidos ao longo de anos e que se mostraram em parte benéficos à atividade. Um

\footnotetext{
${ }^{61}$ Retomando a definição da categoria de assunto que nomeamos como política (geral): discussões teóricas e conceituais mais gerais sobre política, ideologia, regimes econômicos, críticas/definições de capitalismo, definições de anarquismo, socialismo, comunismo, blocos ideológicos e comportamentos adotados como posturas política. Algumas vezes contextualizam época e lugar dos problemas tratados, mas não citam esferas políticas específicas ou não se tratam de questões diretamente relacionadas à atualidade. Uma observação a ser feita é que tais postagens, por falarem de política mais abstratamente ou citando acontecimentos históricos e teorias, entraram praticamente todas na classificação de texto texto opinativo, exceto quando se tratava da divulgação de um evento para debater política, por exemplo, que entrava como notícia ou notícia de movimento ou organização. (Capítulo 2, p.55)

${ }^{62}$ Retomando a definição do formato que nomeamos como texto opinativo: texto ou imagem com texto sem característica de atualidade que permita defini-lo como "notícia" e que explicite opiniões diretas sobre o tema discutido. (Capítulo 2, p.73)
} 
apontamento semelhante foi feito pelo voluntário Pablo ${ }^{63}$, e concordamos com o mesmo. Afora as entrevistas, em que alguma vezes foram provocados a isso, não pudemos quase notar (ao menos no período e mensagens acompanhadas ressaltando), discussões mais aprofundadas entre os voluntários sobre comunicação, e reflexão sobre a atividade que praticam do ponto de vista jornalístico. Apenas as críticas, por certo fundadas, ao modus operandis da imprensa comercial, mas sem uma indicação mais precisa, exceto a orientação independente, sobre boas práticas em jornalismo.

- Deixaríamos como sugestão uma seção no site com tais indicativos, não apenas provindos de livros e manuais (embora não se descarte tais fontes, que têm seu valor), mas principalmente os concluídos em consenso, como ao gosto dos voluntários do CMI, após discussões em fóruns presenciais ou online sobre o tema. Tais indicativos de como se pratica bom jornalismo e as razões para essas escolhas não devem ser estanques, mas dinâmicos, podendo ser alterados com o tempo e a experiência desses próprios jornalistas cidadãos no exercício da reportagem. É bem provável que os textos meramente opinativos, fugindo da proposta do veículo, ainda apareçam na seção de publicação aberta, mas certamente este seria um debate enriquecedor para todos os participantes e traria frutos na qualidade das produções publicadas no site.

Quanto à pesquisa com os voluntários, finalizamos este trabalho acreditando termos cumprido as metas propostas: entre elas, traçar, se não um perfil extremamente definido - cuja existência pode até ser questionada, dada a diversidade do grupo estudado - pelo menos um esboço das características comuns do grupo que mantêm o CMI, em particular das que mais nos interessam nesta análise, que são aquelas que emergem em seus discursos (nas entrevistas, em reuniões, em mensagens trocadas na

\footnotetext{
63 “'(...) isso nunca foi feito por gente com reflexão sobre comunicação. A gente tem uma anedota que ilustra bem isso. Fizemos um encontro da rede CMI Brasil, não me lembro o ano, no Rio de Janeiro, e eram dois dias de discussão. Um dia para gente discutir sobre a organização do CMI, sobre gestão, horizontalidade, decisão por consenso. E outro para falar sobre comunicação, profissionalismo, imparcialidade, neutralidade, perfil de fonte, questões jornalísticas e de comunicação que estavam relacionadas à produção do CMI. No primeiro dia, foi um dos maiores debates que eu já participei na minha vida, com pessoas muito abertas, com muita clareza, e experiência de organização horizontal. Foi um debate maravilhoso, cheio de gente, 100 pessoas debatendo de uma maneira madura e extremamente produtiva. No dia seguinte, tinha 15 ou 20 pessoas, e falaram 3 pessoas. Aquele silêncio... As pessoas não têm reflexão sobre comunicação. Sempre foi um fato que, para elas, aquilo era uma organização política.” (Trecho de entrevista com o voluntário Pablo. Íntegra no Capítulo 3)
} 
internet, e nos textos de apresentação e definição do CMI) e em suas práticas como coletivo que coloca o CMI em funcionamento.

Tais práticas vêm, desde 2001, escrevendo parte importante da história do uso da comunicação social - em particular as que envolvem as novas tecnologias - pelos movimentos sociais; do jornalismo cidadão de fato, considerando as noções de cidadania que aqui assinalamos; da prática autogestionária em organizações sociais e políticas e, como é o caso, na produção e manutenção de um veículo de mídia; e também do movimento antiglobalização (e todos que vêm em seu bojo), ao qual tal veículo esteve intimamente ligado desde o começo.

Utilizando a metodologia das entrevistas abertas, pré-roteirizadas, e incitando a exposição das histórias de vida dos entrevistados, em particular dos momentos que guardavam relação com sua atuação no grupo, procurou-se obter um reflexo da dimensão coletiva a partir das visões individuais. Isto é, fazer os valores, ideais e modus operandi que são a base do CMI como grupo emergirem nas narrativas de ações e opiniões dos entrevistados.

Para analisar as entrevistas, foi adotada a perspectiva da frame analysis, que nos permitiu identificar os enquadramentos através dos quais o mundo e os acontecimentos são interpretados por estes sujeitos, e que espelham tais valores e ideais (não estáticos, é bom, lembrar).

Enfoque cultural, mas que propicia uma esquematização um pouco mais acessível empiricamente do que outras visadas com este acento na análise de movimentos sociais, a metodologia dos frames também nos ajudou a evidenciar as estratégias de construção e difusão destas visões de mundo, na busca não só de novos adeptos para os movimentos sociais como, principalmente, da própria transformação da realidade social abordada, já que os collective action frames incluem um aspecto coletivo e orientado para a ação.

Entre as crenças e valores que sobressaíram no seu discurso, destacamos:

- Há necessidade de democratização da tecnologia e a da comunicação;

- Falta independência financeira e política na grande mídia;

- A cobertura dos movimentos sociais na grande mídia é insuficiente e/ou inapropriada; a união dos movimentos sociais é benéfica; 
- O uso de softwares livres vai ao encontro de tudo que o CMI defende, daí a importância de utilizá-los nos projetos da rede;

- O Estado, em geral, oprime as populações mais desfavorecidas economicamente e também reprime, por meio da polícia, quem se manifesta por mudanças (o que é apontado como criminalização dos movimentos sociais);

- Os defensores do regime capitalista - que é extremamente injusto - por meio de suas empresas e corporações, atuam de várias maneiras, em particular com o monopólio da mídia, para propagar sua ideologia;

- É necessário agir para mudar o estado de coisas insatisfatório que se apresenta no mundo social, e a produção independente de mídia e jornalismo é uma das modalidades de ação, sendo colocada em prática pela Rede Indymedia;

- A autonomia ou autogestão e as decisões por consenso como método devem ser as alternativas à hierarquia e à autoridade, que tolhem o potencial das organizações e de seus participantes, como é identificado, por exemplo, na política exercida por meio do regime de partidos;

- São valores as serem defendidos a justiça social, o direito de expressão, a preservação do meio ambiente, o respeito à diversidade humana (étnica, sexual, de origem social, etc), e o respeito aos animais.

Já as práticas dos voluntários do CMI Brasil nos permitem caracterizá-los como:

- Tendo a internet como meio, não da totalidade, mas de grande parte de suas ações. Assim, trata-se de uma comunidade em parte presencial e em parte virtual, para a qual o papel das novas tecnologias de comunicação é essencial em suas atividades;

- Ativistas, movidos, entre outras coisas, por um sentimento de indignação com as injustiças sociais e os abusos de poder, e que utilizam a ação direta como instrumento;

- Comunicadores, já que produzem e difundem conteúdo midiático, com especificidade do tema dos movimentos sociais prevalecer e de organizarem esta tarefa de uma maneira muito própria, anti-hierárquica e autogestionada;

- Jornalistas, pois praticam várias atividades pertinentes a este fazer: reportagem, redação, edição de texto, fotografia, entrevista, filmagem. Lembrando que, como afirmamos anteriormente nestas "Considerações finais", e inclusive 
apontado por um voluntário, não param o suficiente para refletir sobre esta atividade, o jornalismo;

- Jornalistas cidadãos, isto é, praticantes da modalidade open source ou colaborativa da atividade, porque não a exercem profissionalmente: fazem-na voluntariamente, sem retorno financeiro, e sem que formação acadêmica ou afim lhes seja exigida. Novamente, com a peculiaridade de enfocarem o tema dos movimentos sociais, dando ao termo "cidadão" uma acepção mais profunda que somente "não obrigatoriamente profissional" ou "voluntário"; e também de organizarem esta tarefa de maneira anti-hierárquica e autogestionada;

- Praticantes da comunicação e do jornalismo alternativo, o que afirmamos baseados em uma intercessão de conceitos dos autores lidos que já definiram estas modalidades - justamente em razão de suas especificidades no sistema de produção (autogestionado) e na temática: reivindicação por mudanças e a íntima relação com outros grupos que se movimentam por mudanças. 


\section{Referências bibliográficas e webgráficas}

AGÊNCIA CARTA MAIOR. Editorial publicado em

http://agenciacartamaior.uol.com.br/templates/materiaMostrar.cfm?materia_id=13792.

Acesso em 02/06/2007.

ASSIS, Érico Gonçalves de.Táticas lúdico-midiáticas no ativismo político

contemporâneo. Dissertação de mestrado. Universidade do Vale do Rio dos Sinos,

2006.

ATTON, Chris. A reassessment of the alternative press. In: Media, Culture, Society. 1999, 21, pp. 51-76. Disponível em:

http://gmc.sagepub.com/cgi/content/abstract/2/3/315.

AY CARMELA! http://ay-carmela.birosca.org/Sobre. Acesso em 23/03/2010.

AZZI, Diego de Araújo. Sujeitos e utopias nos movimentos antiglobalização. Dissertação de mestrado. Universidade de São Paulo, 2007.

BENFORD, Robert. Frame Disputes Within the Nuclear Disarmament Movement. In: Social Forces, vol.71, n.3. The University of North Carolina Press, 1993.

BIROSKA. Projeto Servidor das Mulheres. http://docs.birosca.org/wiki/projeto. Acesso em 13/02/2010.

BOBBIO, Norberto. Direita e Esquerda: Razões e significados de uma distinção política. São Paulo: UNESP, 2001.

Elsevier, 2004. . A era dos direitos. Trad. Carlos Nelson Coutinho. Rio de Janeiro:

BOLFARINE, H. e BUSSAB, W. O. Elementos de Amostragem. Belo Horizonte: Sinape, 1994.

BONI, V.; QUARESMA, S. J.: Aprendendo a entrevistar: como fazer entrevistas. em Ciências Sociais. In: Revista Eletrônica dos Pós-Graduandos em Sociologia Política da UFSC, vol. 2, n. 1 (3), janeiro-julho/2005, pp. 68-80.

BOURDIEU, Pierre. O poder simbólico. Rio de Janeiro: Bertrand Brasil, 2001.

BRAMBILLA, Ana Maria. A reconfiguração do jornalismo através do modelo open source. In: Sessões do Imaginário, n.13. Porto Alegre: PUCRS, 2005.

Disponível em:

http://www.pucrs.br/famecos/pos/sessoes/s13/sessoes13_brambilla.pdf.

Acesso em 05/06/2007.

BREIER, Lucilene. Slashdot e os filtros no Open Source Journalism.

Artigo disponível em: http://www.bocc.ubi.pt/pag/breier-lucilene-slashdot.html.

Acesso em 05/06/2007. 
BUCCI, Eugênio; KEHL, Maria Rita. Videologias. São Paulo: Boitempo, 2004.

BURGER, Marcelo Wanderley. Centro de Mídia Independente: ativismo político na Internet e ação direta nas ruas. Dissertação de mestrado. Universidade Federal do Rio de Janeiro, 2004.

BUSSAB, W.; MORETTIN, P. Estatística Básica. São Paulo: Ed. Saraiva, 2004.

CAPARELLI, Sérgio. Imprensa alternativa. In: Comunicação de massa sem massa. São Paulo: Summus, 1986.

CASTELLS, Manuel. A era da informação: economia, sociedade e cultura (3 volumes). São Paulo: Paz e Terra, 1999.

. A Galáxia da Internet: reflexões sobre a Internet, os negócios

e a sociedade. Rio de Janeiro: Jorge Zahar, 2003.

CASTILHO, Carlos. Jornalismo Online - Cada cidadão é um repórter. Artigo publicado no site Observatório da Imprensa em 04/05/2004. Disponível em: http://observatorio.ultimosegundo.ig.com.br/artigos.asp?cod=275ENO001. Acesso em 29/04/07.

CARVALHO, José Murilo de. Cidadania: tipos e percursos. In: Estudos Históricos, n. 18. Rio de Janeiro:1996. Disponível em:

http://www.cpdoc.fgv.br/revista/arq/199.pdf. Acesso em 18/05/08.

CENTRO DE MÍDIA INDEPENDENTE. Página principal. http://www.midiaindependente.org. Acesso em 28/10/2007.

Política editorial.

http://www.midiaindependente.org/static/policy.shtml. Acesso em 05/01/2009. Vídeo.

http://www.midiaindependente.org/pt/blue/static/video.shtml. Acesso em 12/11/2009. Impressos.

http://www.midiaindependente.org/pt/blue/static/impressos.shtml. Acesso em 03/03/2010.

Anticapitalismo.

http://www.midiaindependente.org/pt/blue/static/anticapitalismo.shtml. Acesso em 12/11/2009.

$O$ retorno de Indymedia Itália.

Disponível em: http://www.midiaindependente.org/pt/blue/2008/07/423497.shtml. Acesso em 03/12/2009

Denúncia - Crimes contra homossexuais

na terra do 'socialismo libertário' (artigo assinado por "Gustavo" em 17/09/2009). Disponível em: http://midiaindependente.org/pt/blue/2009/09/454573.shtml. Acesso em $12 / 11 / 2009$.

CHAPARRO, Manuel. Pragmática do jornalismo. São Paulo: Ed. Summus, 1994.

CHINEM, Rivaldo. Imprensa alternativa - Jornalismo de oposição e renovação. São Paulo: Ática, 1995. 
Jornalismo de guerrilha: a imprensa alternativa brasileira da ditadura à internet. São Paulo: Disal, 2004.

CHIZZOTTI, A. Pesquisa em ciências humanas e sociais. São Paulo: Cortez Editora, 1991.

COCHRAN, William G. Sampling techniques. 3a. ed. Nova York: Wiley, 1977.

COSTA, Amanda. 271 políticos são sócios de empresas de comunicação. Texto publicado no site Contas Abertas em 27/05/2008. Disponível em:

http://www.eticanatv.org.br/index.php?sec=4\&cat=9\&pg=4\&noticia=1805fa94afef84 9348e536be82fda39b. Acesso em 15/09/2009.

CROTEAU, David e HICKS, Lyndsi. What a Good Idea! Frames and Ideologies in Social Movement Research. In: Mobilization: An International Journal, vol.5, 2003.

DOWNING, John D.H. Mídia Radical - Rebeldia nas Comunicações e Movimentos Sociais. São Paulo: Senac, 2002.

DEFAY, Jason Bradley (sem data). The Sociology of Social Movements. University of California, San Diego. Disponível em:

http://defay.org/jason/academic/SM\%20Paper.pdf. Acesso em 06/07/2008.

DIMAGGIO, Paul. Culture and cognition. In: Annual Review of Sociology, vol. 23. Annual Reviews Inc, 1997.

ENZENSBERGER, Hans M., Elementos para uma teoria dos meios de comunicação. São Paulo: Conrad Editora, 2003.

FERNÁNDEZ-SAVATER, Amador. Mediactivismo, producción alternativa de imágenes, televisión: una entrevista con Franco Berardi, Bifo. In: Revista El Viejo Topo, n. 203, fev/2005. Barcelona, 2005.

FERRARI, A.T. Metodologia da Pesquisa Científica. São Paulo: McGraw-Hill do Brasil, 1982.

FÓRUM CENTRO VIVO. O que é o Fórum Centro Vivo.

http://www.centrovivo.org/historia. Acesso em 03/04/2010.

GAMSON, William A. Talking Politics. New York: Cambridge University Press, 1992.

GANS, H. Deciding what's news. New York: Vintago Parks, 1980.

GENRO FILHO, Adelmo. O Segredo da Pirâmide: Para uma Teoria Marxista do Jornalismo. Porto Alegre: Editora Tchê, 1987.

GENTILLI, Victor Israel. Democracia de Massas: Cidadania e Informação. Porto Alegre: EdiPUCRS, 2005. 
GILLMOR, Dan. Nós, os media. Lisboa: Editorial Presença, 2004.

GOFFMAN, Erving. Frame Analysis. Cambridge: Harvard University Press, 1974.

GOHN, Maria G. M. Teorias Sobre Os Movimentos Sociais. São Paulo: Loyola, 1997.

GOMES, Pedro Gilberto. O Jornalismo Alternativo no Projeto Popular. São Paulo: Ed. Paulinas, 1990.

GOMES, Wilson. Internet e participação política em sociedades democráticas. In: Revista FAMECOS, n. 27. Porto Alegre: 2005.

GRUMIM. http://www.grumin.org.br. Aceso em 20/08/2008.

GURAK, L. J.; LOGIE, J. Internet protests, from text to web. In: MCCAUGHEY, M.;AYERS, M. D. (eds.). Cyberactivism: online activism in theory and practice. Londres: Routledge, 2003.

INTERVOZES. http://www.intervozes.org.br. Acesso em 06/07/2008.

HABERMAS, Jürgen. Mudança estrutural da esfera pública. Rio de Janeiro: Tempo Brasileiro, 1984. Teoria de la acción comunicativa I - Racionalidad de la acción y racionalización social. Madri: Taurus, 1987.

HAIRCUP, Tony. 'The Unspoken - Said': The Journalism of Alternative Media. In: Journalism, 2003, n.4, pp. 356-376. Disponível em:

http://jou.sagepub.com/cgi/content/abstract/4/3/356. Acesso em 13/08/2009.

HOLANDA, André Fabrício da Cunha. Estratégias de aberturas: O jornalismo de fonte aberta dos casos Indymedia, CMI, Slashdot, Agoravox, Wikinotícias e Wikinews. Dissertação de mestrado. UFBA, 2007.

INDYMEDIA. Articles and quotes on indymedia http://archives.lists.indymedia.org/imc-editorial/2000October/000656.html Acesso em 25/09/2009. . Site internacional do veículo online. http://www.indymedia.org. Acesso em 19/06/2007 e 19/07/2010.

INTERVOZES. O Intervozes. http://www.intervozes.org.br/o-intervozes. Acesso em $12 / 08 / 2008$

JASPER, James. Cultural Approaches in the Sociology of Social Movements. In: ROGGEBAND, Conny; KLANDERMANS, Bert (eds.). Handbook of Social Movements Acros Disciplines. New York: Springer-Verlag New York Inc., 2007.

KOVACH. B., ROSENTIEL, T. Os elementos do jornalismo. São Paulo: Geração Editorial, 2003. 
KUCINSKI, Bernardo. Jornalistas e revolucionários: nos tempos da imprensa alternativa. São Paulo: Scritta, 1992.

KUNCZIK, Michael: Conceitos de jornalismo. São Paulo: Edusp, 2001.

LEAL, Ana Regina B. Rego. Open source journalism e cidadania: Centro de Mídia Independente Brasil. In: Intercom - Revista Brasileira de Ciências da Comunicação, v.30, n.1, pp. 107-128, jun/2007. São Paulo: 2007.

LAGE, Nilson. Ideologia e Técnica da Notícia. Petrópolis: Vozes, 1979.

Estrutura da Notícia. São Paulo: Ática, 1985.

LÉVY, Pierre. A inteligência coletiva: por uma antropologia do ciberespaço. 3. ed. São Paulo: Loyola, 2000.

Cibercultura. São Paulo: Editora 34, 1999.

Ciberdemocracia. Lisboa: Instituto Piaget, 2003.

LINS DA SILVA, Carlos Eduardo e FESTA, R. (orgs.). Comunicação popular e alternativa no Brasil. São Paulo: Paulinas, 1986

MANZINI-COVRE, Maria de Lourdes. Cidadania - tipos e percursos. 3a. ed., 1a. reimpressão. Rio de Janeiro: Brasiliense, 1995.

MARKOFF, John. Artigo no The New York Times. Novembro de 2006. Disponível em: http://noticias.uol.com.br/midiaglobal/nytimes/2006/11. Acesso em 01/02/2010.

MARCONDES FILHO, C. O capital da notícia. São Paulo, 1988. . Jornalismo Fin-de-sècle. São Paulo: ECA-USP, 1991.

MARTINS, José de Souza. Exclusão Social e a Nova Desigualdade. São Paulo: Paulus, 1997.

MEDITSCH, E. O conhecimento do Jornalismo. Florianópolis: Ed. da UFSC, 1992.

MCADAM, D.; MCCARTHY, J.D.; ZALD, M.N. Comparative Perspectives on Social Movements.Cambridge: Cambridge University Press, 1996.

MCCHESNEY, Robert W. Mídia global, neoliberalismo e imperialismo. In: MORAES, Dênis de (org.). Por uma outra comunicação. Rio de Janeiro: Record, 2003.

MCCLURG, Carol Mueller. Building Social Movement Theory. In: MORRIS, Aldon D.; MCCLURG, Carol Mueller (eds.). Frontiers in Social Movement Theory. New Haven: Yale University Press, 1992.

MINHA NOTÍCIA. http://minhanoticia.ig.com.br. Acesso em 13/03/2008. 
MOHERDAUI, Luciana. O usuário de notícias no jornalismo digital - Um estudo sobre a função do sujeito no Último Segundo e no A Tarde Online. Dissertação de mestrado. Universidade Federal da Bahia, 2004.

MINAYO, Maria Cecília de S. O desafio do conhecimento: pesquisa qualitativa em saúde. 2a edição. São Paulo/Rio de Janeiro: Hucitec-Abrasco, 1992.

OBORÉ. http://www.obore.com. Acesso em 20/08/2008.

OHMYNEWS INTERNATIONAL. Site internacional do jornal online coreano. Disponível em: http://english.ohmynews.com. Acesso em 01/02/2010.

OLIVER, P.; JOHNSTON, H. What a good idea: frames and ideologies in social movement research. In: Mobilization: An International Journal, vol.5, 2000.

O'REILLY, Tim. What Is Web 2.0. Design Patterns and Business Models for the Next Generation of Software. 2005. Artigo disponível em:

http://oreillynet.com/pub/a/oreilly/tim/news/2005/09/30/what-is-web-20.html. Acesso em 19/06/2007.

ORTIZ, Pedro Henrique Falco. Z@ patistas online: uma análise sobre o EZLN e o conflito em Chiapas, sua presença na Internet e a cobertura da imprensa mexicana, argentina e brasileira. Dissertação de mestrado. Universidade de São Paulo, 1997.

OVERMUNDO. http://www.overmundo.com. Acesso em 13/03/2008.

PAIVA, Cláudio. Das redes de pesca às redes da imaginação criadora - Novos elementos para uma epistemologia da comunicação. In: Revista Contracampo, vol. 9, n. 0. Rio de Janeiro: Universidade Federal Fluminense, 2003.

PENA, Felipe. Teoria do Jornalismo. Editora Contexto: São Paulo, 2005.

PERUZZO, Cicília K. Comunicação nos Movimentos Populares. Petrópolis: Vozes, 1999.

POBLETE, Juan. Culture, neo-liberalism and citizen communication: the case of Radio Tierra in Chile. In: Global Media and Communication. 2006; n.2, pp. 315-334. Disponível em: http://mcs.sagepub.com/cgi/content/abstract/21/1/51. Acesso em 13/11/2009.

POMBO, Olga. O meio é a mensagem. In: I Caderno de História e Filosofia da Educação. Lisboa: Ed. Departamento de Educação da Faculdade de Ciências de Lisboa, 1994, pp. 40-50.

POLLETA, Francesca. It Was Like a Fever: Storytelling in Protest and Politics. Chicago: The University of Chicago Press, 2006.

PORTAL GENS. http://www.portalgens.com.br. Acesso em 20/08/2008. 
RHEINGOLD, Howard. The Virtual Community: Homesteading in the Electronic Frontier. 1998. Artigo disponível em: http://www.rheingold.com/vc/book/. Acesso em 19/06/2007.

RIGITANO, Maria Eugenia C. Os filtros e o jornalismo participativo: uma proposta de análise da seleção de notícias no Centro de Mídia Independente. In: 404nOtFOund, ano 5, vol. 1, n. 48, novembro/2005. Dísponível em http://www.facom.ufba.br/ciberpesquisa/404nOtF0und/404_48.htm. Acesso em 04/10/2007.

RONDANI, M. Miryám Hess. Energia - Transporte - Direito - Etnias na Perspectiva da Hipótese de Gaia - Estudo de Caso para a Região Metropolitana de São Paulo. Dissertação de Mestrado. Universidade de São Paulo, 2002.

Disponível em:

http://www.iee.usp.br/biblioteca/producao/2002/Teses/tese_Marilia.pdf Acesso em 20/08/2008.

SANDANO, Carlos. A mediação na era da reprodutibilidade em rede: análise da cobertura jornalística sobre o MST e o EZLN nos jornais impressos e na Internet. Dissertação de Mestrado. Universidade de São Paulo, 2007.

SARAVÁ. http://www.sarava.org. Acesso em 23/03/2010.

SCHWINGEL, Carla. A arquitetura da informação e o sistema de publicação do Independent Media Center. Artigo escrito para o V Congreso Iberoamericano de Periodistas en Internet. 2004. Disponível em:

http://www.facom.ufba.br/jol/pdf/2004_schwingel_cmi.PDF . Acesso em 02/05/2007.

SOARES, Raquel Paiva A. A potência emancipatória da comunicação. In: Revista Alceu, vol. 7, n. 13, pp. 199-208. Rio de Janeiro: Pontifícia Universidade Católica, 2006.

SILVA, Nilza Nunes da. Amostragem Probabilística. São Paulo: EDUSP, 2004.

SLASHDOT. http://slashdot.org. Acesso em 19/06/2007.

SNOW, D.; ROCHFORD, E.B.J.; WORDEN, S.; BENFORD, R. Frame Alignment Processes, Micromobilization and Movement Participation. In: American Sociological Review, vol. 51. Washington: American Sociological Association, 1986.

SNOW, D.; BENFORD; R. Ideology, Frame Resonance, and Participant

Mobilization. In: KLANDERMAS, B.; KRIESI; TARROW, S. (eds.). International Social Movement Research: From Structure to Action, vol. 1. Greenwich: JAI Press, 1988.

Master Frames and Cycles of Protest. In: MORRIS, Aldon; MCLURG Carol (eds.). Frontiers in Social Movement Theory. New Haven: Yale University Press, 1992.

Framing Processes and Social Movements: An 
Overview and Assessment. In: Annual Review of Sociology, vol. 26. Annual Reviews Inc., 2000.

Clarifying the Relationship Between Framing and

Ideology in the Study of Social Movements: A Comment on Oliver and Johnston. In: Mobilization, An International Journal, vol. 5, 2000 b.

SWIDLER, Ann. Culture in Action: Symbols and Strategies. In: American Sociological Review, vol. 51. Washington: American Sociological Association, 1986.

TARROW, Sidney. Mentalities, Political Cultures, and Collective Action Frames. In: MORRIS, Aldon; MCCLURG, Carol (eds.). Frontiers in Social Movement Theory. New Haven: Yale University Press, 1992.

. Power in Movement: social movements and contentious politics.

Cambridge: Cambridge University Press, 1998.

THE LINUX COUNTER PROJECT. Estimating the number of Linux users.

Disponível em:

http://counter.li.org/estimates.php Acesso em 23/03/2010.

The Linux Counter. Disponível em:

http://english.ohmynews.com/ArticleView/article_view.asp?menu=A11100\&no=3860 03\&rel_no=1\&back_url=. Acesso em 23/03/2010.

TRAQUINA, Nelson. Teorias do Jornalismo - por que as notícias são como são. Florianópolis: Insular, 2004.

TUCHMAN, G. Making News - A Study in the Construction of Reality. New York: The Free Press, 1978.

UZUNOVA, Marija. Independent Media Centers: By-passing Corporate Media. 2007. Paper disponível em: http://www.scribd.com/doc/2877752/IndymediaBypassing-Corporate-Media. Acesso em 06/08/2008.

VC REPÓRTER. http://www.terra.com.br/vcreporter. Acesso em 13/03/2008.

WIKINOTÍCIAS http://en.wikinews.org/wiki/Main_Page. Acesso em 13/03/2008. 


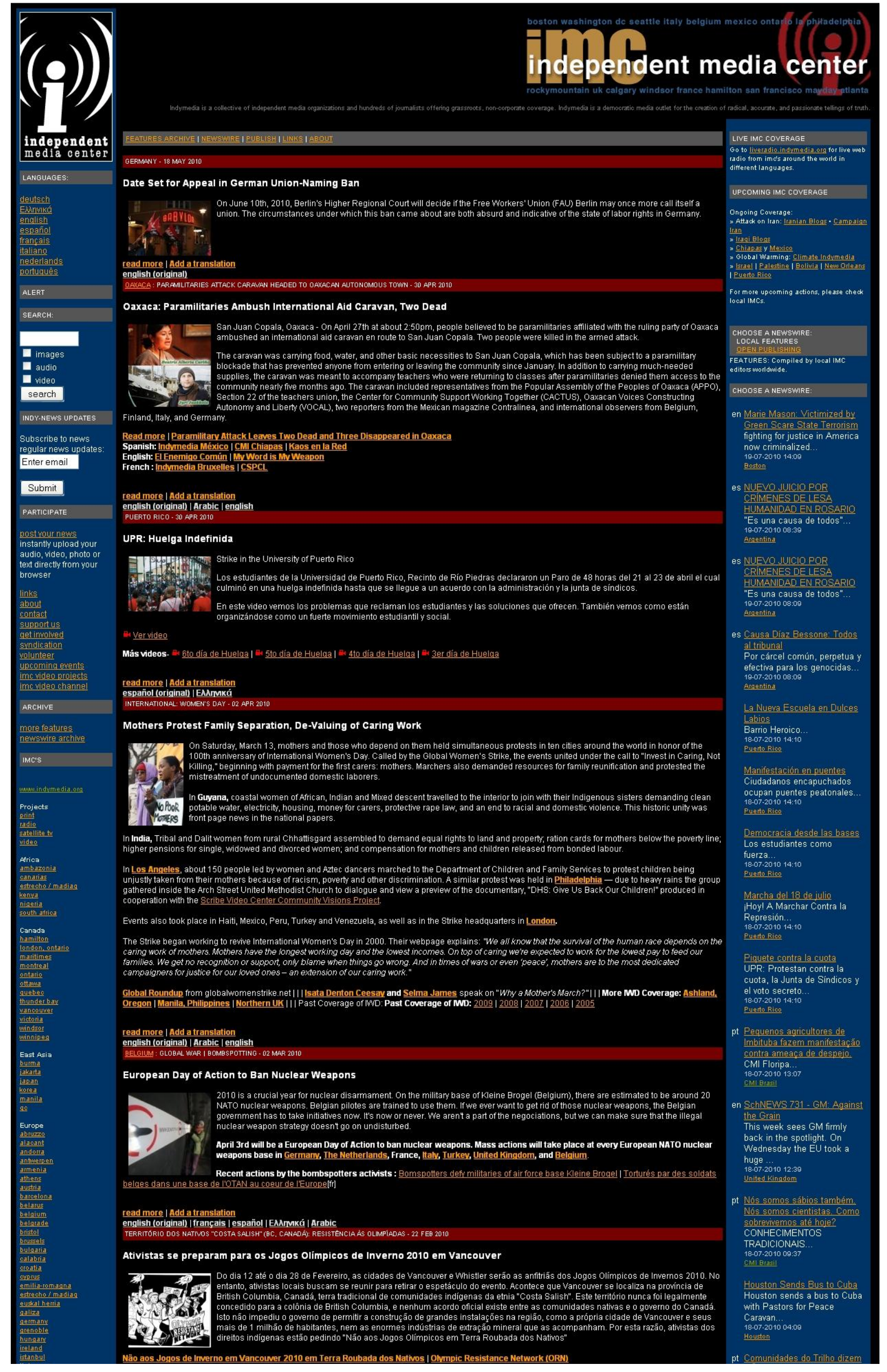




\section{CAMPANHAPELOCANCELAMENTO DA ASSINATURA DA REVISTA VEJA}

\section{Matéria apoiando medidas da prefeitura no centro de São Paulo e criticando o padre Júlio Lancelotti gera movimento por cancelamento de assinaturas}

No dia 11 de janeiro, a revista Veja publicou ples". Veja aponta como problemas do centro, matéria assinada por Camila Antunes intitu- não apenas o crime e o tráfico de drogas, mas lada "A soluçăo é derrubar" na qual apóia as também a açăo dos vendedores ambulantes recentes iniciativas da prefeitura de 5 a Paulo (descritos como" comércio de produtos pirano centro da cidade como a expulsão de am- tas") e, sobretudo, a presença de pessoas pobulantes, a abertura dos calçadరes ao tráfego bres. Para Veja, o centro está degradado, porque de veículos, a desapropriaçăo de moradores adespeito de tentativas de "recuperaçăa" (como pobres e a construçăo de rampas antimendi- a reforma da Estaçăo da Luz, da Pinacoteca e da go. A matéria também ataca pessoalmente 0 Sala 5 ăo Paulo), ele "continua sendo um reduto padre Júlio Lancelotti, da Pastoral do Povo da de pobreza". A própria instalação de 400 familias Rua que tem criticado a prefeitura municipal e sem-teto em prédios abandonados promovida defendido a populaçå pobre que vive no centro da cidade.

A açăo da prefeitura no centro tem sido alvo de muita controvérsia e tem sofrido a oposição sistemática de urbanistas, ONGs e movimentos sociais. A matéria seria apenas mais um elemento na polêmica se não tivesse utilizado uma linguagem manipuladora e agressiva $e$ atacado pessoalmente um dos principais defensores dos direitos humanos da cidade.

A matéria de Veja diz que o centro está degradado e como o título da matéria indica, a única soluçăo para ele é "a demoliçăo pura e sim-

pela última administraçăo é vista não como uma açăo social, mas como um impedimento para a recuperaçăo da regiåo.

0 artigo também lowva a iniciativa da prefeitura de desapropriar imóveis da regiào da Cracolândia sem pagar imediatamente indenização. As desapropriaçర̃es são um instrumento pelo qual o poder público reivindica 0 uso de propriedades privadas para uma finalidade pública, como a construção do metrô. Mas as desapropriaçôes da Cracolândia beneficiarão apenas a iniciativa privada que está sendo convidada a se estabelecer no local com benefícios fiscais. Além de terem suas casas desapropriadas para fins privados, os moradores năo receberăo indenizaçăo até que a prefeitura consiga vender 0 terreno para as empresas. 0 sub-prefeito da regiåo central, Andrea Matarazzo, não se preocupa com 0 destino dessas pessoas e declarou a Veja que os prédios onde moram "são apenas um antro que atrapalha o funcionamento da cidade." A reportagem termina com um violento ataque ao padre Julio Lancelotti que é chamado de "demagogo" e acusado de querer que a populaçăo de rua permaneça na atual condiçăo para que possa manipulá-la politicamente.

0 ataque ao padre Julio Lancelotti, reconhecido em toda a cidade pelo seu trabalho social com os meninos de rua e a identificação dos moradores pobres do centro com assaltantes, bandidos e traficantes deu origem a uma campanha pedindo o cancelamento de assinaturas da revistaVeja. A campanha foi inspirada numa campanha semelhante contra 0 Jornal Zero Hora que foi acusado de manipular os dados nas eleiçøes para governador no Rio Grande do Sul e levou mais de 20 mil leitores a cancelar assinaturas.

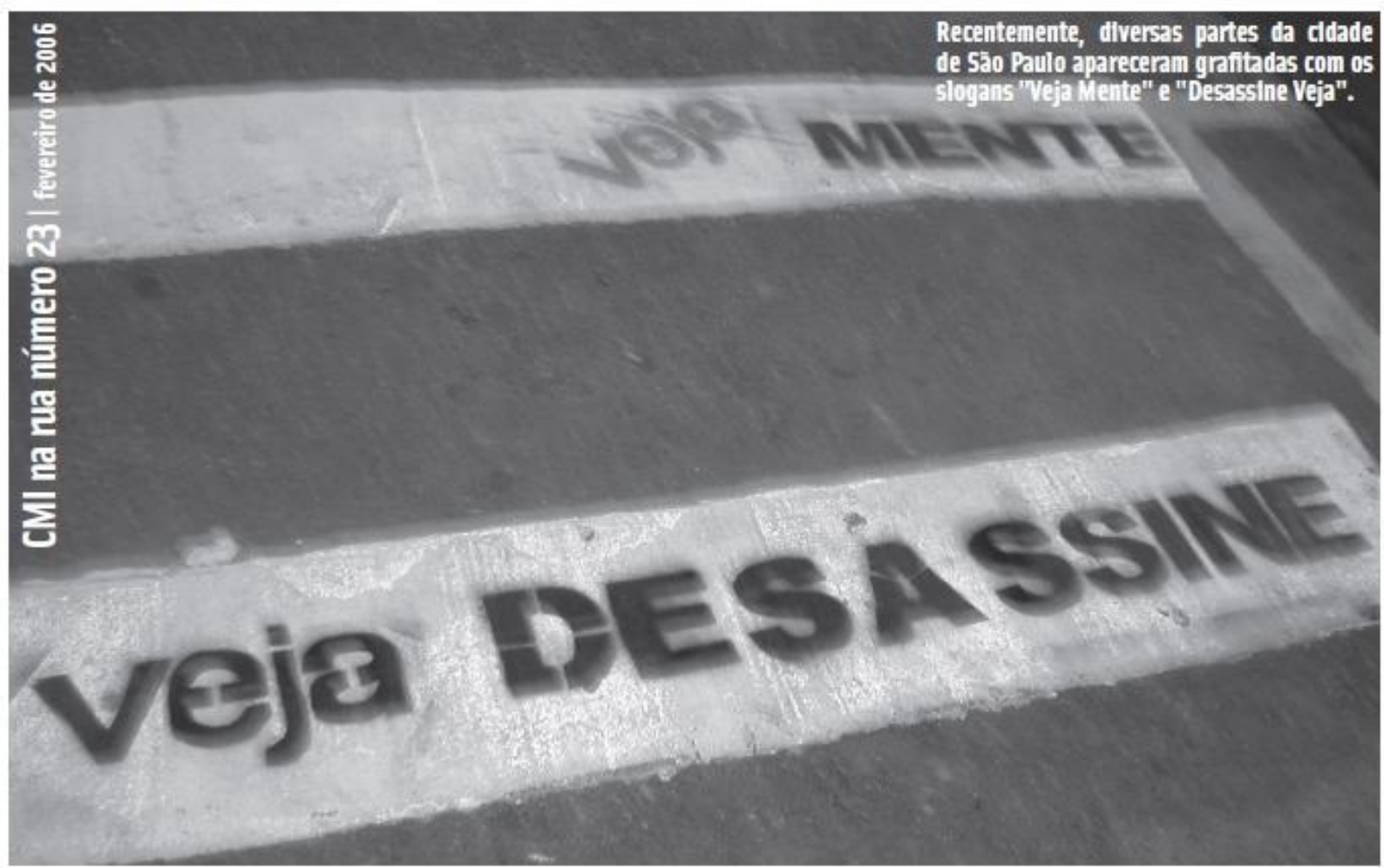




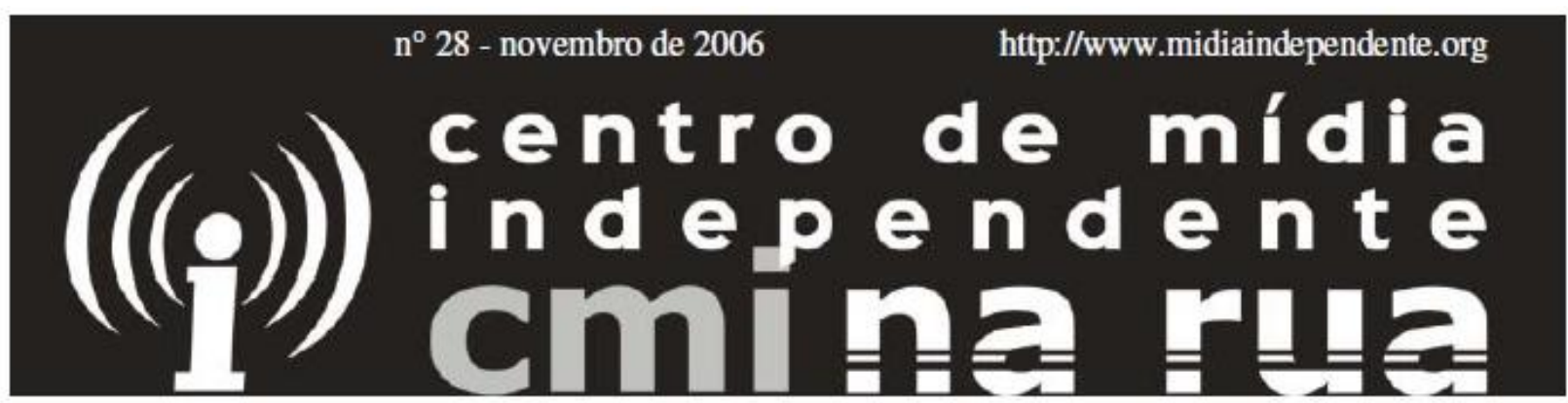

\section{População rejeita o aumento das tarifas dos}

\section{transportes públicos}

Aos gritos de "vem pra rua contra o aumento", "transporte tem que ser público" e "2,30 năo | eu quero andar | de graça no busăo | é um direito!", aproximadamente 800 pessoas se manifestaram na cidade de Sằo Paulo no dia 24 de novembro. Mais que lutar contra o aumento de $15 \%$ nas tarifas de ônibus, anunciado para os próximos dias, 0 ato foi contra a existência de uma tarifa para um serviço considerado público.

O percurso do ato foi

Reje

Motivos para repudiar o aumento...

Aumento de $15 \%$, passando dos atuais $\mathrm{R} \$ 2,00$ para $\mathrm{R} \$ 2,30$.

Desde o último aumento em Março de 2005, quando a tarifa subiu de $R \$ 1,70$ para $\mathrm{R} \$ 2,00$, o índice de inflaçăo do periodo, segundo o IPCA, foi de $6,9 \%$. decidido em assembléias pela Força Tática da Polícia organizadas ao longo da Militar, que entrou no manifestação, que passou terminal soltando bombas pelo Vale do Anhangabaú, de gás e batendo nos prefeitura, Praça do Correio manifestantes. Muitas e Terminal Parque Dom pessoas ficaram feridas, Pedro II. No terminal foram duas foram detidas e feitos bloqueios ao som de "se a tarifa aumentar, a cidade vai parar" e "operações portas abertas", nas quais os manifestantes abriam as portas traseiras dos ônibus para usuários e usuárias entrarem sem pagar.

A manifestaçăo foi reprimida

\section{aumento de $15 \%$ nas} liberadas durante a madrugada.

Mesmo assim o movimento năo desanimou e convoca Grande Ato para esta quinta-feira, dia 30 , às 16 horas em frente ao teatro Municipal. A saída será às 18horas.

passagens de ônibus
A prefeitura alega o aumento ser necessário para diminuir o impacto nos cofres públicos. Porém, esses cálculos permanecem escondidos.

Serviço prestado piora, há diminuiçáo da frota, corte de linhas e maior lotação dos ônibu, alem de restriçoes ao bilhete único.

Apesar de nossa constituiçăo afirmar que o Transporte é um direito básico, săo empresas privadas que controlam os ônibus de Săo Paulo e de outras cidades brasileiras. Assim, quando há aumento de tarifa o que está em jogo nesta concepçăo de transporte săo os lucro\$ dessas mesmas empresas.

Em 12 anos as tarifas de ônibus subiram $400 \%$ em Săo Paulo.

Centro de Midia Independente (CMI) é uma rede internacional de produtores e produtoras de midia livre e independente dos interesses empresarias e governamentais. O cMl na Rua é uma publieação do coletivo de Säo Paulo. A reproduçäo total ou pareial da matéria é permitida para fins näo comerciais. 0 CMI também possui projetos de vídeo, rádio e internet. Para mais informaçöes entre em contato pelo e-mail

www.midiaindependente.org 


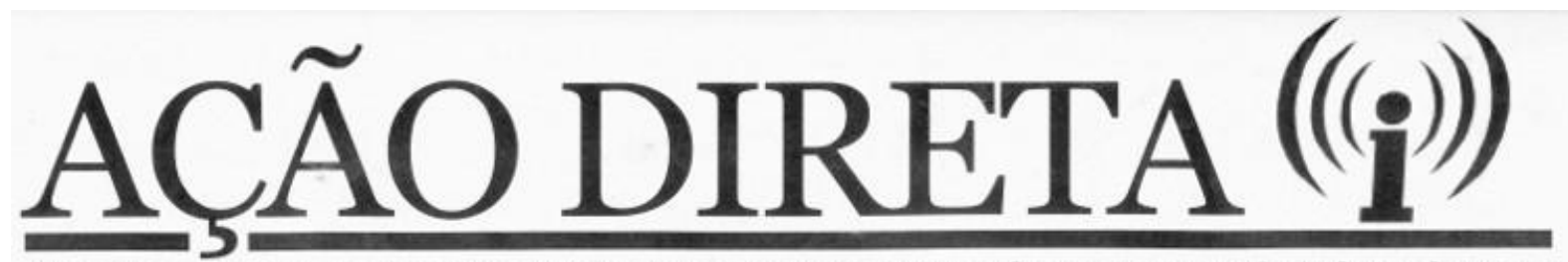

Setembro de $2002 \cdot$ Uma publicação do Centro de Mídia Independente $\bullet$ www.midiaindependente.org

\section{A ALCA é muito pior do que você pensa}

Acordo pode gerar desigualdade, perda de direitos e degradação ambiental

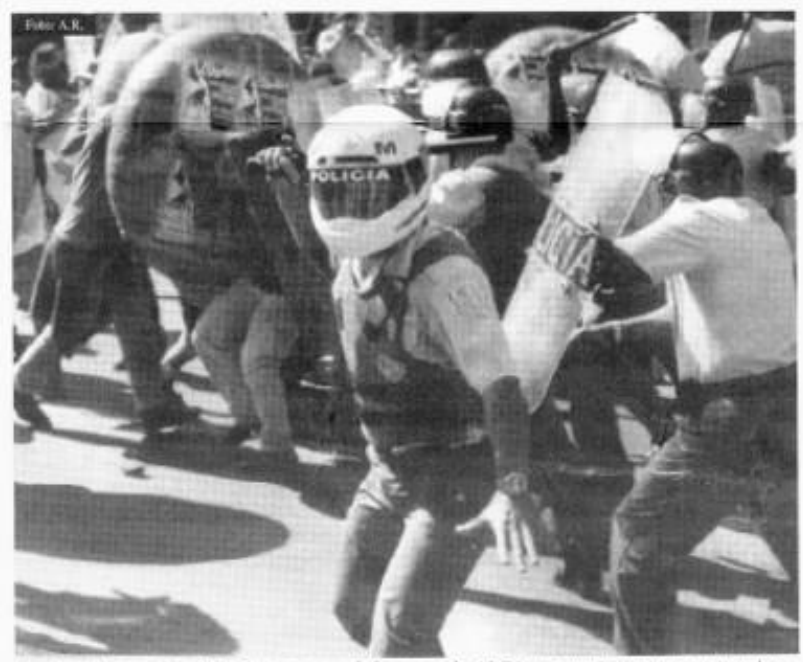

ALCA é a sigla para Área de Livre Comércio das Américas, um acordo que visa constituir um bloco comercial com livre circulaçầ de bens, serviços e capitais em todo o continente americano (com a exceção de Cuba). A ALCA comecou a ser discutida em 1994 por iniciativa dos Estados Unidos que queriam ampliar a experiência do NAFTA (Acordo de Livre Comércio da América do Norte) para todo o continente.

Oprocesso de negociaçấo da ALCA é alvo de muitas críticas, uma vez que é totalmente feito a portas fechadas sem a participação da sociedade civil ou mesmo do poder legislativo dos países. Depois de protestos populares em Buenos Aires e Québec em abril de 2001, os governos decidiram divulgar uma versão parcial do acordo em julho do mesmo ano. Essa versâo liberada é confusa porque lista propostas contraditórias entre os paises que participam das discussões sem mencionar quem sugeriu o que. Como jả divulgaram essa versão preliminar e obscura, os governos executivos acham que já deram por cumprido seu dever "democrático", Todas as negociacốes posteriores continuaram e continuarão sendo feitas às escondidas, sem a participaçăo e nem mesmo o conhecimento da sociedade civil, da imprensa ou dos congressos. Apesar disso, mais de 500 grandes empresas têm acesso ao conteúdo do acordo ma condiçăo de "assessores".

Com base no que ia acontece no NAFTA e na OMC e no que se sabe da versio liberada do acordo, a ALCA pode gerar maior desigualdade social, perda dos direitos trabalhistas, privatizaçõo de serviços sociais, regras mais rigidas de propriedade intelectual e pode dar à empresas poder para barrar leis sociais que ameacem seus lucros.

Sien Paulo, 20 de abril de $2001 \mathrm{ros}$ defencors da AlCA uprt

Segundo semestre é marcado por mobilizações contra a ALCA Plebiscito e protestos mostram descontentamento com o acordo

\begin{tabular}{|lr|}
\hline Globalizaçâo & pag. o2 \\
\hline NAFTA & pag.03 \\
\hline Investimentos & pag.04 \\
\hline Vocé näo foi convidado & pag. 05 \\
\hline Patentes & pag. o6 \\
\hline Agricultura & pag.07 \\
\hline Servicos Sociais & pag. 08 \\
\hline
\end{tabular}

As mobilizacies contra a ALCA no segundo se. ALCA em debate no Brasil. mestre seguem um proxesso de contestacîo do acor- No comego do més de setembro, a campanha condo que se intensifieou desde abril do ano passade, tinental contra a ALCA ganha o reforco do Plebiscito Nos das 6 e 7 de abril de 200 t, milhares de pessos Naciomal contra a ALCA, uma iniciativa que pretende CN. Duas do eseu processo de negocincāp. No mis seguinte, de ministros da economia que discutiam a ALCA. Duas do e seu processo de negociaçär. No més seguinte, de emanas depois, em 20 de abril, outras milhares de 31 de outubro a f de novembro, enquanto ministros de pessoss sairam as ruas em todo o continente para estado de todo o contimente se reunem para discutir a protestar contra a reuniâo de chefes de estado que Al.CA em Quito, no Equador, milhares de pessoas desatma acontecendo em Quelec. Para proteger o en- vem sair às ruas de todo o continente para protestar contro do descontentamento popular foi construida contra a ALCA. No Brasil, diversos grupos de base escontro do descontentamento popular foi constrūa tâo se organizando para protestos simultâneos contra

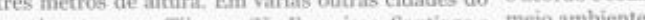

continente, como Tijuana, Săo Franciseo, Sintiago e meso ambicnte. Nova lorque, pessoas sairam às ruas simultaneamen- te para protestar contra o acordo, Em Säo Panlo, duas as no site do Centro de Midia lindeperidente mil pessoas protestaram contra a AlCA e foram du- (www.midiaindependente.org) e analises ramente reprimidas pela policia. A presenca dos jo- aprofundadas no site www.alcarallho.org do grupo Açắ vens nas ruas e a violenta repressāo policial chamou Local.

a atençáo da opiniâo pública e colocou o tema da 